\title{
Influence of Tradition in Creating Signatures of Cultural Identity in Product Design
}

\author{
Ana Zdravkova* \\ Faculty of Mechanical Engineering, Industrial Design, Ss "Cyril and Methodius" University of Skopje, Skopje, Republic of \\ Macedonia
}

\begin{abstract}
Citation: Zdravkova A. [Influence of Tradition in Creating Signatures of Cultural Identity in Product Design]. SEE J Arch Des. 2021 Sep 27; 10059:94. [MSc] [Macedonian] http://doi.org/10.3889/seejad.2021.10059

Key words: New product development; Design methodology; Design elements; Design principles; Cultural identity; Traditional design.

Correspondence: Ana Zdravkova. Faculty of Mechanica Engineering, Industrial Design, Ss "Cyril and Methodius" University of Skopje, Skopje, Republic of Macedonia. E-mail anazdravkova@yahoo.com

Received: 14-Sep-2021; Revised: 21-Sep-2021; Accepted: 26-Sep-2021; Published: 27-Sep-2021

Copyright: $\odot 2021$ Ana Zdravkova. This is an open-access Atributistributed under the terms of the Creative Common distribution, and reproduction in any medium, provided the original author and source are credited.
\end{abstract}

Competing Interests: The author have declared that no competing interests exist.

\begin{abstract}
The goal of this master thesis is to research and develop a methodology for adaptable reconstruction of specific aspects from traditional Macedonian objects, in order to obtain inspiration for new designer products. The new products, either through their appearance or their functionality, will strive to maintain the cultural aspects, in order to enable a stronger relationship with the end users.

The main focus of this master thesis is the conducted research to find which design elements and principles are authentic for the Macedonian handcrafted objects and how to implement them in contemporary industrial design and infuse them with the recognizable traditional values. The aim is to extract a general overview of forms by analysing functional objects, while recognizing the elements and principles from decorative items that have the highest cultural value. Both types of objects add up to the feeling of identity in a time when design trends, aesthetics and functionalities are adopted from global trends overthrowing the local ones.

In the making of this master thesis contemporary methods and procedures are applied. First, an overview of scientific literature will be made in the fields of aesthetics that cover the application and meaning of elements and principles in design, and their influence on design aesthetics. At the same time an overview of the influence of tradition in other cultures will be made, as well as the contribution of tradition in elevating the emotional value of products.

The final goal of this thesis is the formation of a methodology or a strategy that will be used to extract visual characteristics of Macedonian traditional objects and explore its applications in modern design products with recognizable Macedonian cultural and traditional attributes. A selection of traditional examples has been made and has been sorted in a few categories. Through observation of the examples, the collected data has been categorized by identifying the characteristic forms, colours, tones, textures and materials. The forms are reinterpreted by applying principle of deconstructivism. The end result of this phase is a base of characteristic elements (form, colour, tones, textures and materials) and characteristic principles (composition, rhythm, balance, simplicity, achieving unity, etc.), which carry the visual recognisability in Macedonian tradition. And finally, this base is applied as an inspiration toolset for designing specific products, whose visual characteristics reflect upon the recognisability of Macedonian culture and identity.
\end{abstract}




\title{
РЕПУБЛИКА СЕВЕРНА МАКЕДОНИЈА
}

Универзитет „Св. Кирил и Методиј“, Скопје

МАШИНСКИ ФАКУЛТЕТ, СКопје

\section{Влијанието на традицијата во креирањето обележја на културниот идентитет во дизајнот на производи}

\author{
Кандидат: Ана Здравкова
}

Ментор: Проф. д-р. Софија Сидоренко

Постдипломски студии по Индустриски дизајн и маркетинг

Скопје, 2021 
Ментор:

Членови на комисијата:

Дата на одбрана:

Дата на промоција:
Проф. д-р Софија Сидоренко

Машински факултет - Скопје

Проф. д-р Софија Сидоренко, ментор

Машински факултет - Скопје

Проф. д-р Татјана Кандикјан

Машински факултет - Скопје

Проф. м-р Ладислав Цветковски

Факултет за ликовни уметности - Скопје 


\section{Влијанието на традицијата во креирањето обележја на културниот идентитет во дизајнот на производи}

\section{Апстракт}

Целта на оваа магистерска работа е да се проучи и развие методологија за адаптивно реконструирање на одредени аспекти од традиционалните македонски предмети како можна инспирација за нови дизајнерски производи. Новите производи преку нивниот изглед или фукционалност треба да се стремат кон задржување на културните аспекти со цел подобро да се преточат традиционалните културни вредности во функционални творби со нов лик и притоа да се овозможи поцврста релација со крајните корисници.

Во оваа магистерска работа спроведено е истражување чиј главен фокус е да се најде одговорот кои дизајнерски елементи и принципи се автентични за македонските традиционални рачно произведени предмети и како истите можат да бидат имплементирани во модерниот индустриски дизајн со цел да се даде препознатливост на традиционалните вредности. Со проучување на функционалните предмети треба да се извлече генерална идеја за формите, додека од декоративните може подетално да се препознаат ликовните елементи и принципи кои се олицетворение на македонската традиција. И двата вида предмети создаваат чувство на идентитет во време кога дизајнот и трендовите за естетика и функционалност произлегуваат од глобалните стандарди наспроти локалните.

Во изработката на магистерскиот труд се применети современи методи и постапки во областа на дизајнот. Најпрво е извршено проучување на научни трудови од областа на естетиката кои се однесуваат на примената и значењето на елементите и принципите во дизајнот и нивното влијание врз конечната естетика на производите. Истовремено, проучувани се научни трудови за влијанието на традицијата во дизајнот кај другите народи, а разгледани се и примери за придонесот на традицијата во подигнувањето на емоционалните вредности на производите во другите култури.

Крајната цел на овој труд е воспоставување методологија, поточно стратегија, за извлекување на визуелните карактеристики на македонските традиционални предмети и за нивна примена во дизајн на нови модерни производи со препознатливост на македонската култура и традиција. Избрани се релевантни примери на традиционални производи кои се распределени во неколку категории. Извршена е обработка на собраните информации со примена на методот на опсервација и препознавање на карактеристички форми, бои, нијанси, текстури и материјали. Формите се реинтерпретирани со примена на геометриска анализа. Крајниот исход е база од карактеристични елементи (форми, бои, нијанси, текстури и материјали) и карактеристични принципи (композиција, ритмика, рамнотежа, симплификација, единство итн.), токму тие што создаваат визуелна препознатливост на македонските традиционални предмети.

Клучни зборови: дизајн на нови производи, дизајнерска методологија, дизајнерски елементи, дизајнерски принципи, културен идентитет, традиционален дизајн. 


\section{Ana Zdravkova}

\section{Influence of tradition in creating signatures of cultural identity in product design}

\section{Abstract}

The goal of this master thesis is to research and develop a methodology for adaptable reconstruction of specific aspects from traditional Macedonian objects, in order to obtain inspiration for new designer products. The new products, either through their appearance or their functionality, will strive to maintain the cultural aspects, in order to enable a stronger relationship with the end users.

The main focus of this master thesis is the conducted research to find which design elements and principles are authentic for the Macedonian handcrafted objects and how to implement them in contemporary industrial design and infuse them with the recognizable traditional values. The aim is to extract a general overview of forms by analysing functional objects, while recognizing the elements and principles from decorative items that have the highest cultural value. Both types of objects add up to the feeling of identity in a time when design trends, aesthetics and functionalities are adopted from global trends overthrowing the local ones.

In the making of this master thesis contemporary methods and procedures are applied. First, an overview of scientific literature will be made in the fields of aesthetics that cover the application and meaning of elements and principles in design, and their influence on design aesthetics. At the same time an overview of the influence of tradition in other cultures will be made, as well as the contribution of tradition in elevating the emotional value of products.

The final goal of this thesis is the formation of a methodology or a strategy that will be used to extract visual characteristics of Macedonian traditional objects and explore its applications in modern design products with recognizable Macedonian cultural and traditional attributes. A selection of traditional examples has been made and has been sorted in a few categories. Through observation of the examples, the collected data has been categorized by identifying the characteristic forms, colours, tones, textures and materials. The forms are reinterpreted by applying principle of deconstructivism. The end result of this phase is a base of characteristic elements (form, colour, tones, textures and materials) and characteristic principles (composition, rhythm, balance, simplicity, achieving unity, etc.), which carry the visual recognisability in Macedonian tradition. And finally, this base is applied as an inspiration toolset for designing specific products, whose visual characteristics reflect upon the recognisability of Macedonian culture and identity.

Keywords: new product development, design methodology, design elements, design principles, cultural identity, traditional design. 


\section{Содржина}

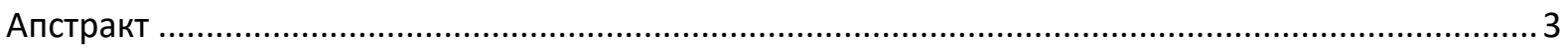

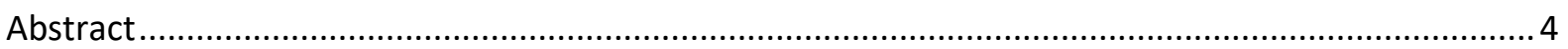

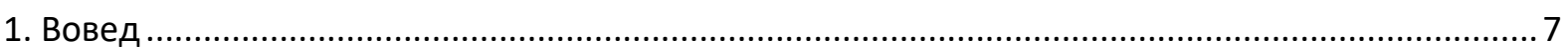

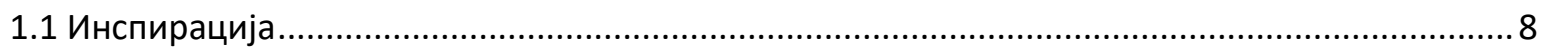

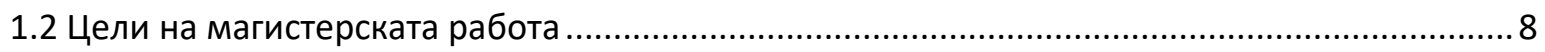

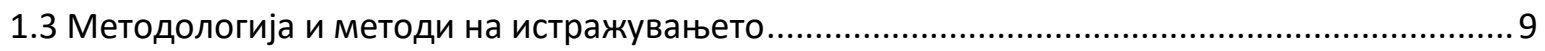

2. Интерпретација на традицијата во современиот дизајн - студии на случај …........................... 11

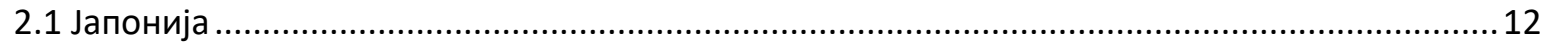

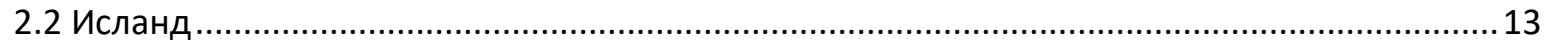

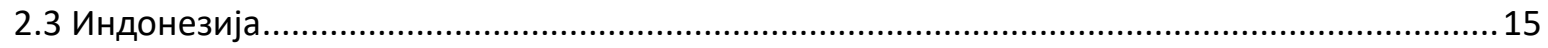

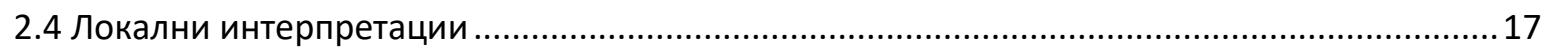

2.4.1 Аркадна традиција - проф. М-р. Ладислав Цветковски .................................................. 17

2.4.2. Комрад Дизајн / Komrad Rug - Дијана Томиќ Радевска ............................................... 18

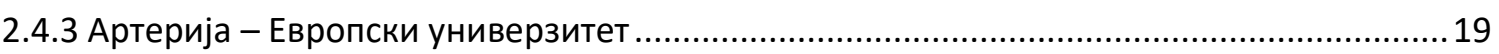

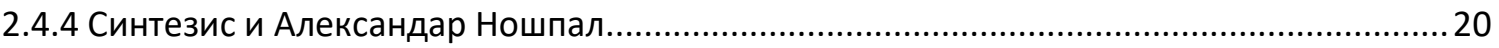

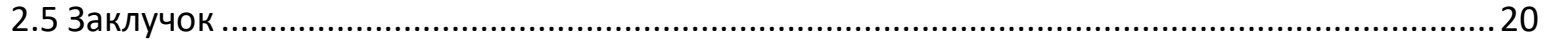

3. Истражување на постоечка литература од областа на естетиката .............................................22

4. Методологија за извлекување градбени елементи за визуелниот идентитет на македонската

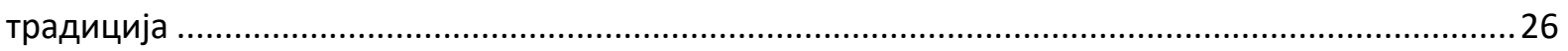

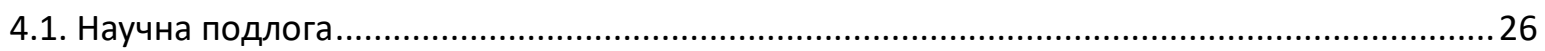

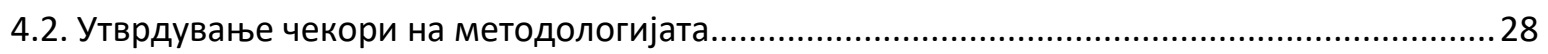

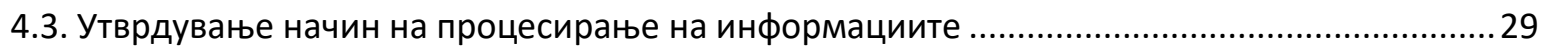

4.4. Препознавање на функционалноста на производите и можноста за алтерации ................32

5. Анализа на обележјата на културниот идентитет во дизајнот на дела од македонската

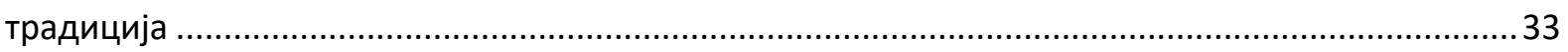

5.1 Собирање, селекција и класифицикација на предмети за анализирање .............................33

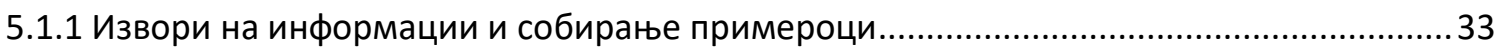

5.1.2 Селекција и класифицикација на предмети за анализирање........................................ 38

5.2 Анализа и проучување на применетите дизајн елементи и принципи .............................. 46

5.2.1 Анализа на елементите ……....................................................................................... 46

5.2.2 Анализа на дизајн принципите по категории производи .............................................61

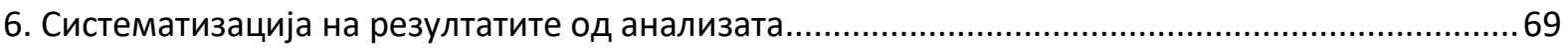




\section{1. Геометриска анализа на 2Д градбените елементи извлечени од дизајнот на}

традиционалните текстилни предмети

6.2. Геометриска анализа на градбените принципи извлечени од дизајнот на традиционалните текстилни предмети..

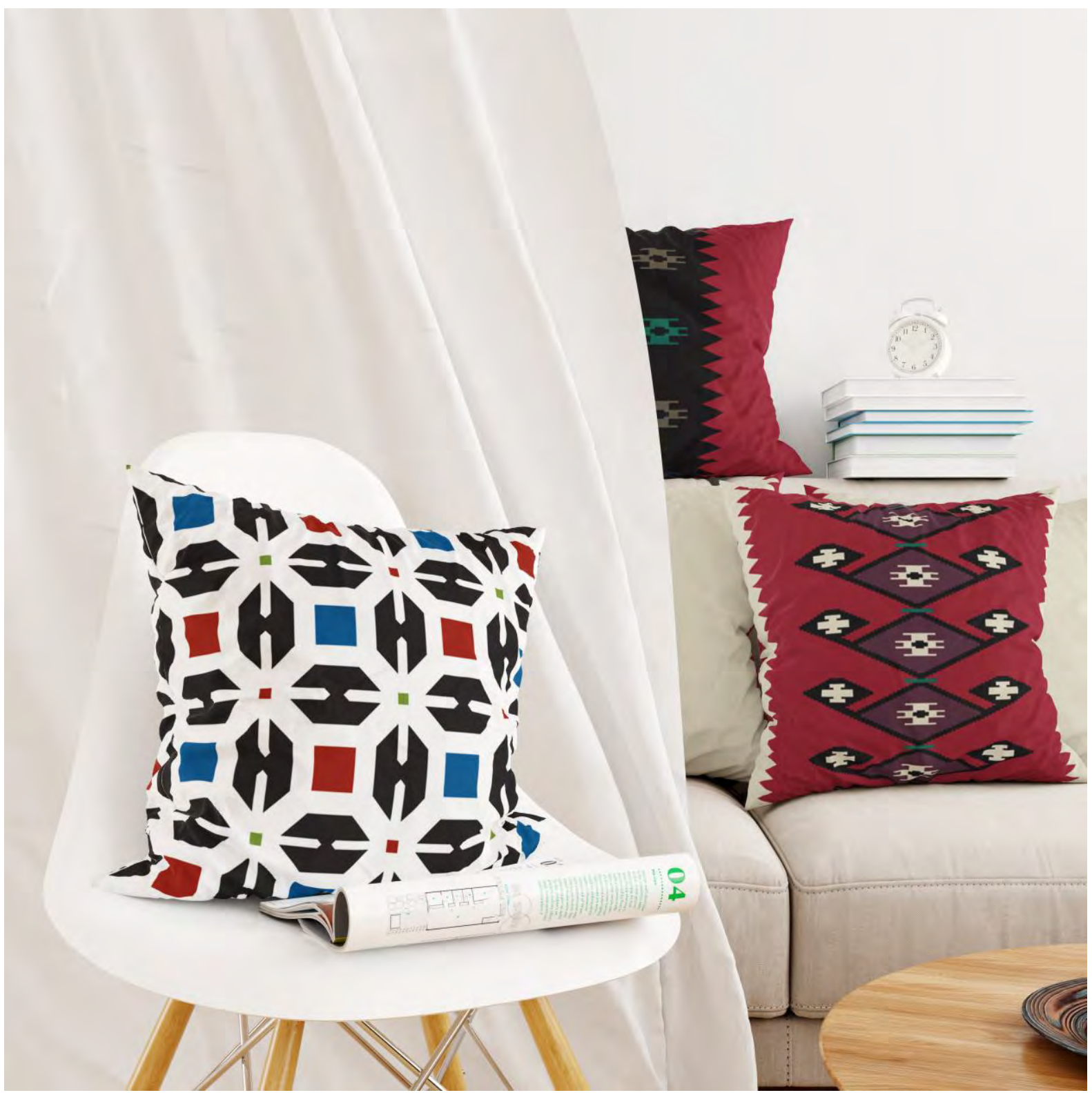




\section{1. Вовед}

Како мултидисциплинарна алатка за создавање визуелно прифатливи и функционални предмети, индустрискиот дизајн има цел да ги подобри односот и интеракцијата на корисникот. Во процесот на создавање на одреден предмет, дизајнерот треба да земе предвид како неговиот дизајн ќе го подобри или поедностави процесот на извршување одредена активност и како истиот ќе биде визуелно впечатлив и ќе го долови карактерот на корисникот. Понекогаш функционалноста на еден производ не е толку влијателен критериум за успехот на производот колку што е доловувањето на карактерот.

Кои сѐ работи сака да ги искаже корисникот преку производите што ги употребува или ги поседува? Предмети од глобален интерес, како преференции за музика, спорт, визуелна уметност, стил, боја итн. веќе постојат, благодарение на глобализацијата, комуникацијата преку интернет и социјалните медиуми. Но, кога станува збор за посуштинскиот начин на изразување, во кој се вклучени минато, културното наследство и традицијата, истите не се толку застапени во дизајнот на македонските производи.

Со занемарувањето на културните вредности, со тек на времето, овие традиционални обележја се забораваат, макар што имено тие се уникатен израз и печат на одреден народ како дел од модерното општество. Секој народ има чувство и потреба за културен идентитет и сопствени заеднички карактеристики што ги дефинираат. Тие се препознаваат според работите што се поврзани со нивната вообичаена примена во секојдневниот живот, гледано низ призмата на предметите $и$ алатките кои постојано се користат, а дополнително претставуваат препознатлив белег на едно општеството.

Глобалните трендови имаат сериозно влијание врз автентичноста на народите поради нивната обврска да се создадат производи соодветни за сите, наспроти дизајнирањето конкретни производи за конкретна демографска група корисници. Демографско-центрираниот дизајнерски процес и фокус создаваат подобри производи за дадената целна група, поради тоа што посоодветно кореспондираат со потребите на корисниците и нивните вредности. Со цел да се разбере подобро една специфична демографска група, неопходно е да се направи истражување на етнографијата на истата.

И покрај тоа што дизајнот мора да се приспособува на постојаните промени на потребите на корисниците кај едно население, мора да постојат и одредени елементи што дизајнот ќе го поврзат со традицијата на просторот во кој живее. Секое население има сопствена автентичност којашто доминира, но со текот на времето се занемарува. Дополнително, во свет преполн со информации и новокомпонирани колективни вредности, многу луѓе понекогаш имаат потреба да воспостават одредена врска со нивните локални вредности.

Почетокот на секој процес на дизајнирање е идентификувањето на проблемот. Независно за каков производ станува збор, секое раѓање на нов дизајн има цел да ги надмине проблемите со кои корисникот се соочува или да ги подобри претходните производи.

Дизајнерските трендови креативно ги критикуваат моменталните начини преку кои се изразуваме, како што се графичкиот и индустрискиот дизајн, архитектурата, филмографијата, фотографијата и другите применети уметности. Како последица од индустриската револуција, која својот најголем подем го доживува по втората светска војна, се забележува забрзано и зголемено производство на сите производи што ги користиме, од потрошни до долготрајни. 
Зголемената индустријализација и хиперпродукцијата го имаат значително подобрено начинот на живеење, но има и очигледни влијанија врз развојот на човештвото. Забрзаниот животен ритам, зголемениот пристап до информациите, како и постојаната потреба за приспособување на модерните трендови придонесуваат кон потребата да се потсетиме на одредени постари принципи на живеење и функционирање.

Како критика на овој тренд, дизајнерите од сите полиња се навраќаат на „поедноставните времиња", поточно црпат инспирација од руралните средини и фолклорот на народот. Изборот на материјали, начинот на изработка, формата и функцијата што навестуваат или се реадаптирани од културните мотиви создаваат поголемо чувство на удобност. Притоа овие, доколку може да се наречат производи, имаат многу силна врска и со природата поради малкубројните чекори за преработка на истите и поради тоа што се изработени од луѓе. Овие предмети во себе го содржат духот на народот, genus loci [1].

\section{1 Инспирација}

Главната инспирација и мотив за да се истражи македонската култура и културно наследство произлегува од личната потреба за културно изразување. Многу модерни производи, функционални и декоративни, успеваат да ги доловат личните интереси, но недостатокот на производи што алудираат на моето потекло, се најчесто нефункционални предмети што патувале низ генерациите. Нивната застареност, недостаток на применливост во модерното живеење и макотрпно одржување, се спротивставуваат на прогресивните и забрзаните потреби на корисникот и најчесто завршуваат во отпад.

Разгледувајќ ги успешните обиди за редефинирање и редизајнирање на културното наследство со поприфатлива форма во другите светски култури, се создаде потреба и нагон, сличен на подвиг, да се изработи проект што ќе ги истакне и вгради во употреблив производ македонските традиционални вредности.

\section{2 Цели на магистерската работа}

Целта на оваа магистерска работа е да се разгледа и развие соодветна методологија за адаптивно реконструирање на одредени аспекти од традиционалните македонски предмети во нови дизајнерски производи. Новите производи, преку нивниот изглед или фукционалност, треба да се стремат кон задржување на културните аспекти, со цел подобро да се транскрибираат културните вредности со нов лик и притоа да се овозможи поцврста релација со крајните корисници.

Според хиерархијата на потреби на Маслоу [2], чувството на припадност е една од фундаменталните основи кон самоостварувањето. Паралелно со тоа, претставувањето на елементи од традицијата дополнително го зајакнува тоа чувство на припадност. Недостатокот на модернизирани производи со примеси од културното наследство, не само што ја оттуѓува традицијата од нејзините припадници, туку, исто така, може да создадат и чувство на алиенација и изолираност од некаков тип на заедничка целина.

Македонската традиција имала многу влијанија во текот на нејзиното формирање. Таа е вткаена во бројните примери на разновидни производи наменети за секојдневниот живот, рачно изработувани од вешти занаетчии. Такви се примерите во областа на текстилните производи, накитот и декоративните производи, покуќнината, архитектонските детали и сл. 
Земајќ ги како појдовна точка традиционалните мотиви, во рамките на оваа магистерска работа е направено темелно истражување чиј главен фокус е да се најде одговорот на прашањето: Кои дизајнерски елементи и принципи се автентични за македонските традиционални предмети и како истите можат да бидат имплементирани во модерниот индустриски дизајн со цел да се даде препознатливост на традиционалните вредности?

За да се дојде до крајната цел на ова истражување беше неопходно да се разгледаат следните аспекти:

1. Кои се автентичните дизајнерски елементи (линија, форма, боја, простор, тон, насока и димензија) и принципи (контраст, хармонија, пропорција, рамнотежа, ритам, градација, акцент, хиерархија итн.) што ја дефинираат македонската визуелна препознатливост?

2. Која е разликата меѓу поранешната и сегашната бихевиорална шема што ги дефинира дневните потреби и обичаи на луѓето на нашето поднебје?

3. Кои производи би можеле, според одговорите на првите две прашања, да се реимплементираат во модерното македонско живеење со алтерации на формата и избор на материјалите?

Со проучување на функционалните предмети може да се склопи генерална идеја за формите што визуелно го доловуваат нивото на иновативност за ефикасно извршување одредени обврски, додека од декоративните може подетално да се препознаат елементите и принципите што ја зацврстуваат македонската традиција. И двете врсти предмети создаваат чувство на идентитет во време кога дизајнот и трендовите за естетика и функционалност произлегуваат од глобалните стандарди наспроти локалните. Многу предмети од минатото нема да може да се редизајнираат со цел подобро да се вклопат во домаќинството, поради тоа што низ времето истите ја изгубиле нивната секојдневна улога или биле заменети со други предмети. Но, од нив можат да се преземат впечатливите визуелни детали што би можеле да се аплицираат на нов начин. Од друга страна, од декоративните предмети може да се соберат многу повеќе дизајнерски информации поради самата нивна улога да декорираат.

Конечната цел е да се анализираат двата типа предмети: функционалните предмети, чиј рок на употреба згаснал поради промените во функционирањето, но нивните форма, облик и материјал можат да бидат искористени како основа за развивање нови производи; и декоративните предмети, кои можат да послужат како инспирација за изразување во графичкиот дизајн, дизајнот на текстилни и декоративни производи, но и многу пошироко. Новитетите не треба секогаш да задоволат голема маса на луѓе, понекогаш новитет е колку луѓето можат спиритуално да се поврзат со предметот зависно од нивните искуства и околина.

\section{3 Методологија и методи на истражувањето}

Во изработката на магистерскиот труд беа применети современи методи и постапки во областа на дизајнот. Во првата фаза беа разгледани примери што покажуваат каков е придонесот на традицијата во подигнувањето на емоционалните вредности на производите во другите култури, преку конкретен осврт на исландската, јапонската и индонезиската култура. Од оваа фаза беа извлечени корисни насоки за реимплементирање во конкретниот случај со интеграција на македонските традиционални вредности во современиот дизајн. Потоа беше извршено проучување на научни трудови од областа на естетиката кои се однесуваат на примената и значењето на елементите и принципите во дизајнот, вклучувајќ́ го и нивното 
влијание врз конечната естетика на производите. Истовремено беа проучувани научни трудови за влијанието на традицијата во дизајнот кај другите народи.

Втората фаза беше посветена на собирањето информации, посета на Етнолошкиот, Историскиот и Археолошкиот музеј, посета на Скопската старата чаршија и занаетчиски работилници, интервјуа со занаетчии и ракотворци, потрага по актуелни здруженија, проекти, работилници, кои се занимаваат со македонската традиција, и, конечно, проучување на научни истражувања од областа на македонската етнологија.

Во третата фаза беше извршена обработка на собраните информации со цел да се извлечат конкретни дизајнерски елементи и принципи. Со примена на методот на опсервација беше извршено препознавање на карактеристичните форми, бои, нијанси, текстури и материјали. Формите беа реинтерпретирани со примена на геометриски анализи. Крајниот исход од оваа фаза е базата карактеристични елементи (форми, бои, нијанси, текстури и материјали) и карактеристични принципи (конкретна ритмика, редослед на појавување, примена на контраст и хармонија, единство итн.), токму тие што создаваат визуелна препознатливост во македонската традиција.

Четвртата фаза беше наменета за проверка на поставените цели преку дизајн на серија производи креирани врз база на идентификуваните дизајнерски елементи и принципи, автентични за македонската култура и традиција. Станува збор за серија производи кои соодветствуваат на потребите и барањата на корисниците и притоа ги поседуваат сите модерни атрибути.

Во заклучокот се презентирани резултатите од истражувањето и можностите за понатамошна разработка, чија цел е подигнување на современиот македонски дизајн со вклучување на македонските традиционални обележја. 


\section{2. Интерпретација на традицијата во современиот дизајн - студии на случај}

Во ова поглавје се разгледани и прикажани примери што посочуваат каков е придонесот на традицијата во подигнувањето на емоционалните вредности на производите во другите култури, преку конкретен осврт кон исландската, јапонската и индонезиската култура. Целта на оваа фаза е да се извлечат корисни насоки за реимплементирање во современ дизајн инспириран од македонските традиционални вредности.

Рурално инспирираните структури сѐ почесто се забележуваат во модерните трендови, меѓу кои и термините како рурализирање, рурални куќи, рурални амбиенти. Иако овој тренд е генерално воден во архитектурата, се забележува потребата за навраќање кон што е можно поедноставен и поприроден дом и средина (сл.1. и 2). Архитектите на Пол Улман [9] се инспирираат од изгледот и изборот на материјали кај традиционалните штали и конструираат прибежишта од градските средини со сите модерни потреби. Тие ги вметнуваат најпрепознатливите визуелни карактеристики на оригиналните градби и се фокусираат да ја доловат атмосферата преку ентериерот и екстериерот.
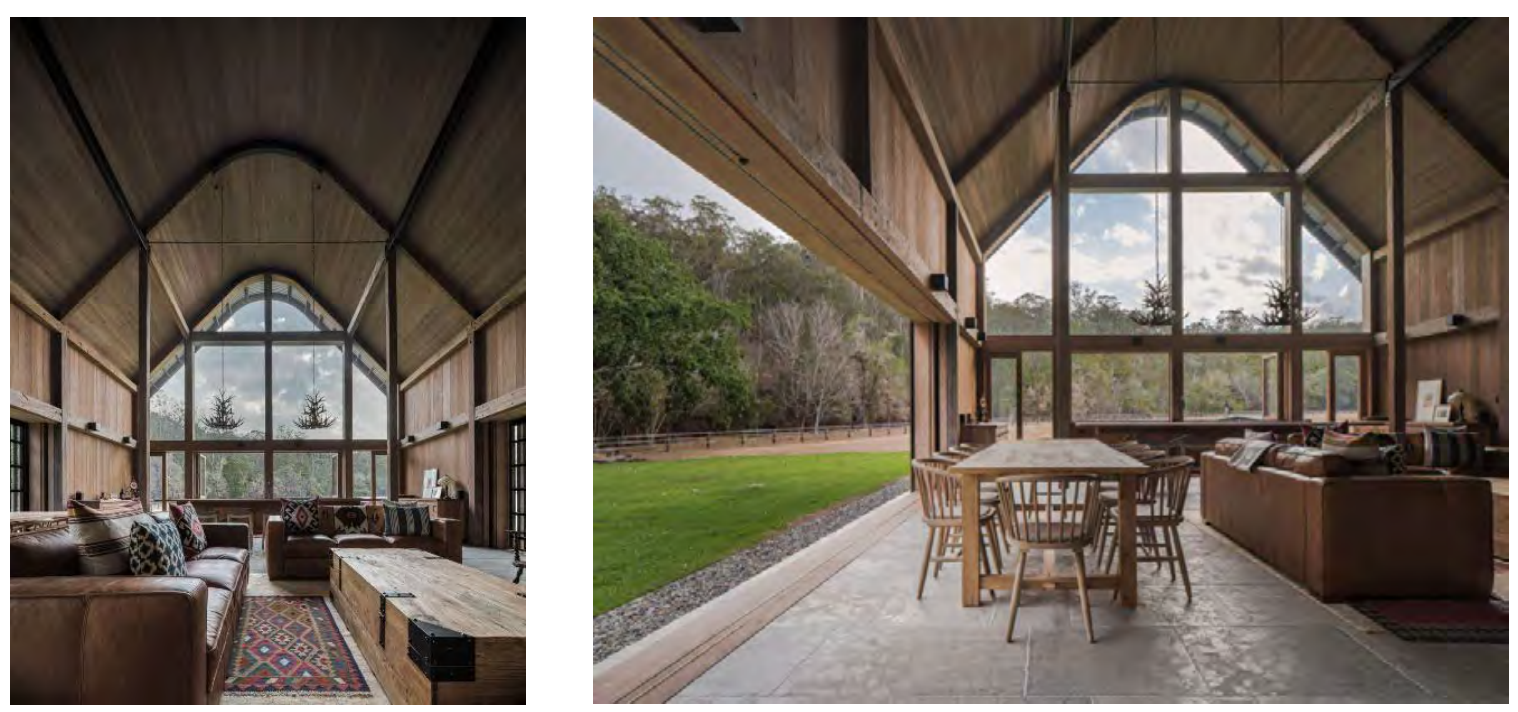

Сл.1 и 2 Ентериер инспириран од рурални австралиски штали, дизајн на Пол Улман

Во овој пример се гледаат транслативното дизајнирање и адаптивната пренамена. Оригиналната структура, чија задача е да складира и да заштитува добра, се пренаменува во простор за живеење, при што дизајнот произлегува од формата, но користи модерни технологии и нови материјали. Ова е единечен, ексклузивен пример по нарачка. Но, постојат поголеми потези во дизајнот, поточно во преведувањето на традицијата и врската со природата во модерен контекст, на ниво на култура, област, држава.

Следните три култури имаат три различни проблеми во областа на задржувањето на културните облежја низ вековите и во модерното време. Јапонија, Исланд и Индонезија се земени поради три проблеми што дошле до израз последниве децении: 
- Јапонија го губи културното влијание кај новите генерации поради брзата вестернизација и странските елементи, заради кои младите ги претпочитаат странските обележја наспроти сопствената култура.

- Исланд се стреми да создаде поуникатно културно изразување со цел да се разграничи до одреден степен од нејзините дански и норвешки предци и притоа да ги прифати невообичаените природни непогоди по кои е препознатлива.

- Индонезија поминува низ повеќекратна религиозна и воедно културна преродба низ нејзината историја којашто создава слоеви разновидни влијанија врз примарниот спиритуален културен идентитет.

\section{1 Јапонија}

Јапонската традиција се развива уште од периодот преку еден милениум пред нашата ера. Влијанието на високиот културен развој на Јапонија се забележува и денес, започнувајќ од самото однесување на народот [10]. Високото ниво на почит и строгоста на Јапонците е препознатлива карактеристика меѓу странските држави.

Долгогодишниот развој на занаетите, грнчарството, столарството, агрикултурата, текстилот, музиката итн. ја зајакнале основата за денешната култура во Јапонија. Јапонските дизајнери и инженери постојано развиваат нови и иновативни технологии и дизајни благодарение на оваа основа, независно од тоа дали станува збор за редизајнирање на одреден предмет од минатото во денешницата или пак имплементирање на одредена техника, принцип или елемент од древните занаети во нешто ново и уникатно (сл.3. и 4 на следната страна).

Меѓy најпочитуваните јапонски традиционални занаети се плетењето и ткаењето. Како симбол на поимотните жители, комплексноста и деталите во јапонскиот текстил укажуваат на општествениот статус. Но, како што замираат статусните симболи и присуството на глобалните модни стилови, се поставува прашањето како ќе преживее оваа уникатна форма на изразување? [11]

Клучните проблеми што се несоодветни кај модерното функционирање на корисниците го вклучуваат долгото време на изработка (боење, ткаење и работна рака), скапите материјали за изработка, големиот простор за грешка и високата цена. Шибори техниката за ткаење се смета за една од најкомплексните јапонски шари за изработка меѓу катазоме, јузен, касури и сурихаку техниките, поради тоа што кореспондирала со барањата од корисниците со повисокиот социјален статус, додека техниките хира-ори, монша и ринзу биле наменети за средните слоеви [12]. Секоја техника има сопствена препознатлива шара на плетење и соодветен дезен.

Кој атрибут од шибори техниката е попрепознатлив и повреден за транзиционирање во модерниот моден дизајн? Шарата на плетењето или дезенот? Јапонските дизајнери се фокусираат на двата аспекта. Благодарение на модерните технологии за изработката на текстил, на двата аспекта им е соодветно пристапено, при што се зголемува достапноста и кон поголема маса на луѓ и се намалува цената на производство. Изборот на материјали е сменет од свила во полиестер, поради полесното манипулирање со синтетичките влакна, дезените се аплицирани на помодерни парчиња облека наместо на традиционалното кимоно, визуелниот изглед на шарите на плетењето се заменети со 3D нерамнини и текстури итн [13].

Јоџи Јамамото, јапонски моден дизајнер, ги редефинира јапонските традиционални облеки на два начина: преземени се оригиналните облици на кимоното и истите се преработени со 
отстранување на одвишниот декор и смененети се боите и материјалот или преземени се дезените од кимоното и се префрлени врз поприфатливи модни парчиња (сл. 5. и 6). Редефинираното кимоно на Јамамото, изработено во средината на 90-тите години е обид за презентирање на автентичноста на јапонскиот текстилен дизајн како извор за инспирација за помладите дизајнери и уметници [13]. Целта на Јамамото е да се задржат јапонската спиритуалност и естетика како автентични симболи на јапонското општество во брзорастечкиот бран на модата.
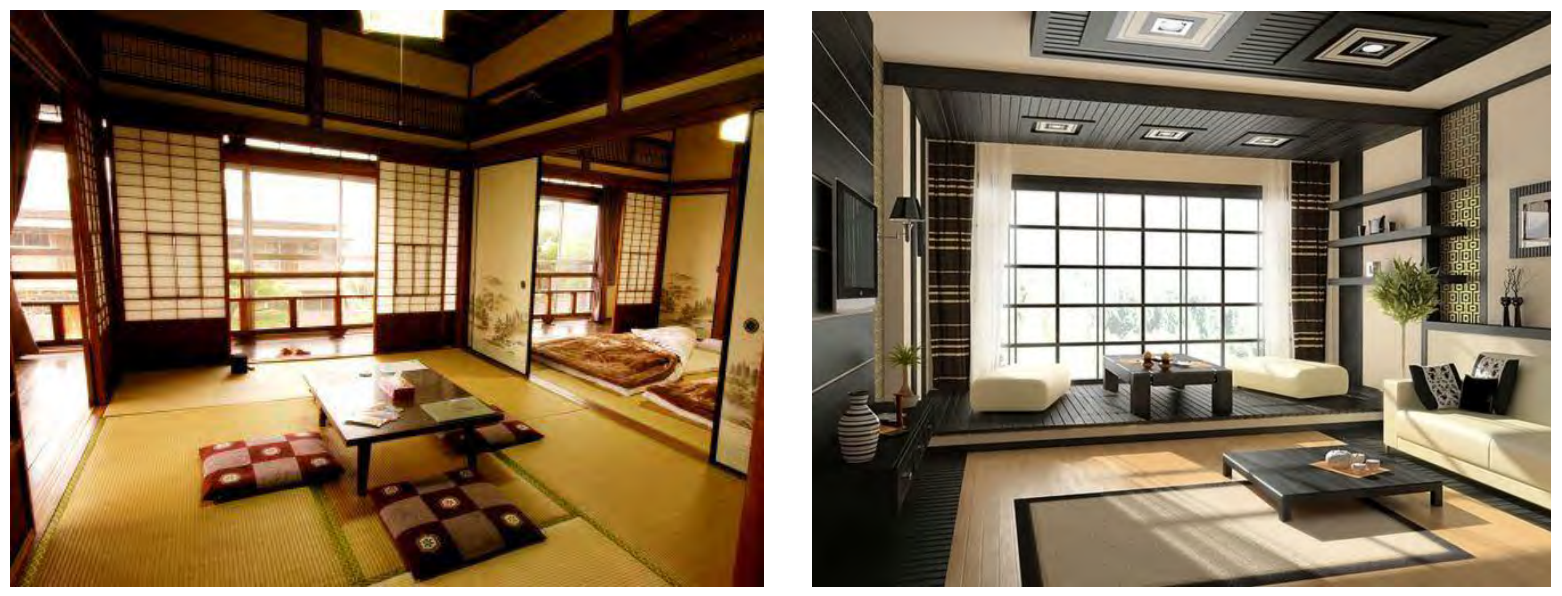

Сл. 3 и 4 Традиционален јапонски простор и современ традиционално инспириран дневен простор
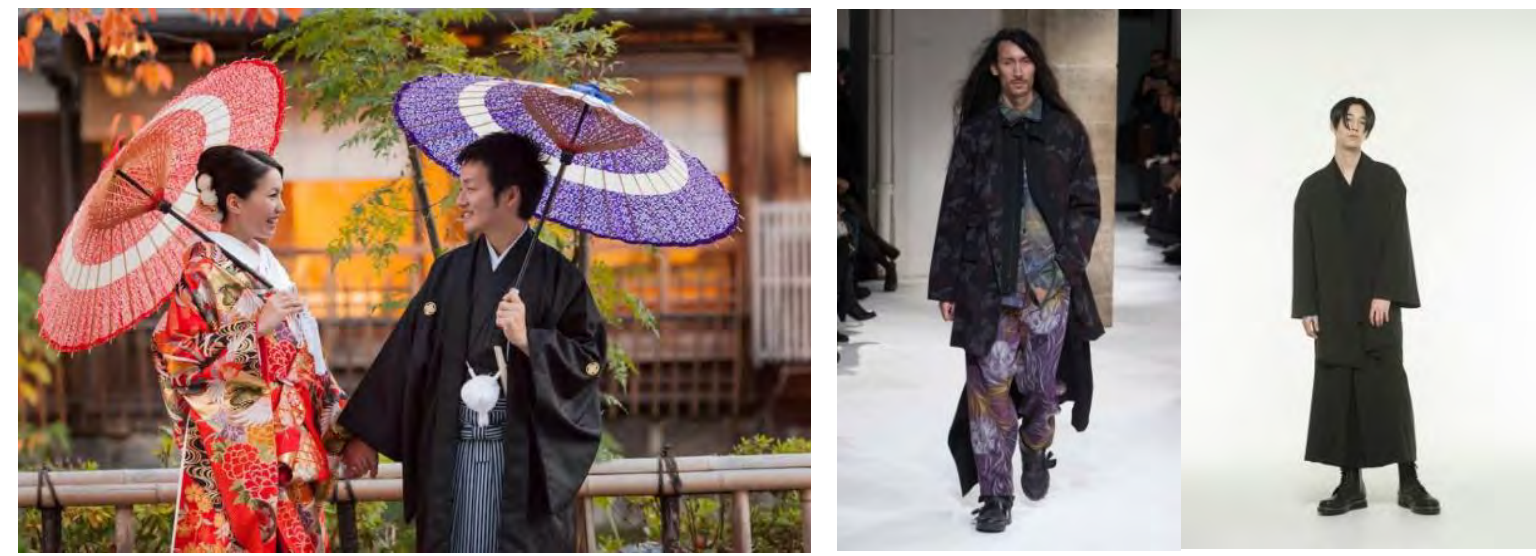

Сл. 5 и 6 Традиционално јапонско кимоно и дизајните на Јоци Јамамото

\section{2 Исланд}

Карактерните и бихевиоралните особини се темелат врз тоа како еден народ се развивал низ годините и притоа прераснал во основа за формирање на одреден идентитет. Исландските дизајнери во нивните обиди да создадат нов дизајнерски тренд во 70-тите и 80-тите години, не го оспориле своето колонијално потекло како потенцијална контаминација за тоа што значи да си вистински Исланѓанец. Тоа е потекло што не можат да го одречат, иако имало негативно влијание при создавањето на Исланд, поконкретно со векови територијата и идентитетот на Исланд биле растргани од страна на нивните основачи [14]. 

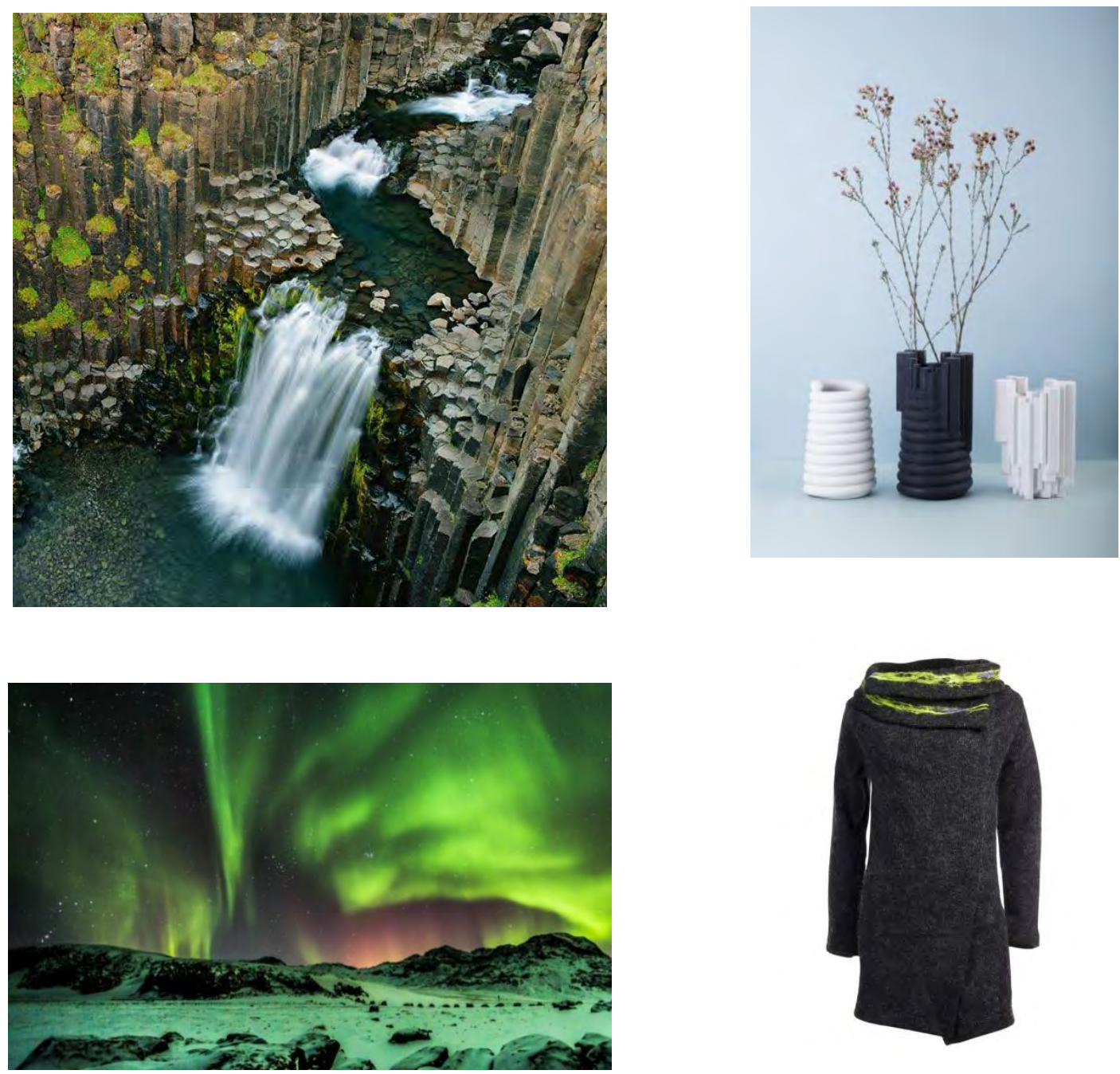

Сл. 7 - 10 Уникатните природни феномени во Исланд и предмети инспирирани од истите

Интересната сличност меѓу Исланд и Македонија е тоа што идентитетот на двете култури бил формиран и развиван поради екстерни влијанија и сили. И двете држави се релативно млади поради нивното доцно оформување како независни суверени држави и се соочуваат со проблемот кој ја поседува оваа територија и овој народ. Во текот на овие спорови, народите на двете држави се развиваат во уникатна насока којашто ги прифаќа моменталните влијанија, ги задржува претходните вредности и развива нов идентитет во целиот тој процес.

По завршувањето на споровите во Исланд, како природна потреба за воспоставување и оформување нов идентитет, исландските дизајнери заклучиле според кои фактори и можности може да се создаде нов дизајнерски бран. Изолираноста на земјата, непристапната географска положба, честите природни катастрофи, па дури и невообичаените траења на денот и ноќта создаваат одредена непожелност од страна на туристите да ја посетат земјата. Но, поради доброто интерконтинентално растојание меѓу европскиот и америчкиот континент, Исланд претставува многу добра воздушна меѓустаница. Тоа значи дека сепак има значителен број туристи коишто ја посетуваат земјата и имаат желба со себе да понесат одреден сувенир со себе од чудниот остров. 
Сите проблеми спомнати во претходниот пасус станале поттик на исландските дизајнери да создадат уникатни дизајнерски парчиња што ќе ги привлечат туристите и ќе се разликуваат во однос на нивните скандинавски предци. Лајтмотивот за ова претставува колонијалното минато, пост-колонијалната фаза на идентитет, нордската митологија и нордскиот фолклор [15]. Како дополнителна инспирација, во овој процес се искористени и странските асоцијации што создале одреден стереотип за островот, а тоа се неговите специфични природни убавини. Присуството на гејзири, вулкани, глечери и поларната светлина се токму тој клучен фактор што ги прави исландските дизајнерски производи попрепознатливи за потенцијалните корисници, посебно за туристите, па дури потоа и за локалното население (сл.7.-10 на претходната страна). Сувенирите имаат цел да го доловат минатото и да ги зацврстат националната самосвест, креативнатаа моќ и културното наследство на Исланд [16, 17].

\section{3 Индонезија}

Индонезиската орнаментација и декор се сметаат за канали за изразување на повисоки филозофски идеали, естетика, спиритуалност и духовен мир. Независно од тоа дали станува збор за делови од декоративните кровови, ситни детали во дизајнот на ентериерот или накит, овие елементи го задржуваат духот на народот, genius loci [18]. Автентичните декоративни елементи се сметаат за еден од повпечатливите и попрепознатливите детали од индонезиската култура.

Пристапот на дизајнирање преку додавање одржлива иновација како дел од процесот на истражување и развој е од сѐ поголем интерес кај младите дизајнери. Како да се издизајнира нешто ново, со одредена вредност за корисниците, а притоа се темели врз долгогодишните традиции и обичаи на еден народ и како истиот може потенцијално да се подобри благодарение на модерната технологија и трендови? Иновацијата не е создавање директна копија, ниту пак е реставрација. Одржливата иновација има цел да помогне при идентификување конкретни елементи и принципи што овозможуваат модерна транслација, а притоа даваат можност да бидат и разгледани можностите за подобрување од аспект на форма, избор на материјал, функција, начин на изработка, и слично.

Дрводелството е специфичен занает, чии производи се присутни насекаде во Индонезија, од орнаментација на храмови до домашни декорации. Влијанието на хиндуизмот има оставено големо социо-економско влијание врз народот, не само заради учењето нови техники и занаети, туку и заради емотивното и спиритуалното влијание што секој предмет го носи во себе. [19] Колку е некој предмет помакотрпен за изработка, толку творецот повеќе ја внесува сопствената душа во изработеното парче. И покрај религиозното преминување кон исламот, индонезиските занаетчии задржале мотиви од хиндуизмот во изработените резби, збогатени со композиција преземена од исламските мотиви.

Голем дел од резбите немаат никаков функционален карактер, но во нивниот изглед носат голем дел од културниот идентитет на Индонезија. Религијата игра голема улога во вредностите на народот и истото се гледа во резбите. Декоративните елементи се преземени од флората на локалното население, додека нивната организација и шема е препознатливо исламска [20].

Неколку можности влегуваат во игра кога станува збор за модернизирање одреден предмет со минимална, скоро никаква функција, а тоа се: интегрирање на естетскиот елемент, директна 
интеграција и адаптибилна интеграција [21]. Интегрирањето на естетскиот елемент значи позајмување на одреден елемент од резбата, одреден редослед на поставување на шарите во резбата, одредена форма, пропорција во некој комплетно нов предмет. Дизајнерските принципи можат да бидат употребени во дизајн на нов предмет што има сосема нова функција и изглед во споредба со оригиналниот производ.

Директната интеграција значи буквално употребување на одреден дизајн без никакви модификации во нешто друго. Овој метод го задржува уникатниот локален идентитет и е корисен кога станува збор за дизајнирање со цел да се задржи комплетно автентичниот изглед, но не придонесува кон иновација. Од друга страна, овој пристап има и секундарна интерпретација и можност, а таа е како одреден ефект создаден од страна на некој предмет може да се префрли во модерен дизајн. На пример, напладне, кога сонцето паѓа под многу низок агол и остава портокалова светлина, одредени орнаменти и предмети создаваат нов вид искуство за корисниците. Понекогаш целта е да се долови тој ефект преку директната интеграција, што веќе носи кон некаков тип иновативно размислување.

Адаптивната интеграција е веќе многу поиновативен пристап во дизајнирањето. Целта е да се прилагоди оригиналнот дизајн со комбинирање други дизајнерски елементи и принципи, при што се задржуваат важните форми од оригиналниот дизајн. Ако се земе елемент од индонезиската резба и се смени организацијата од ортогонална во кружна, веќе тоа се смета за адаптибилна интеграција [22]. Оригиналот е присутен, ама е подобрен (сл.11. - 14).
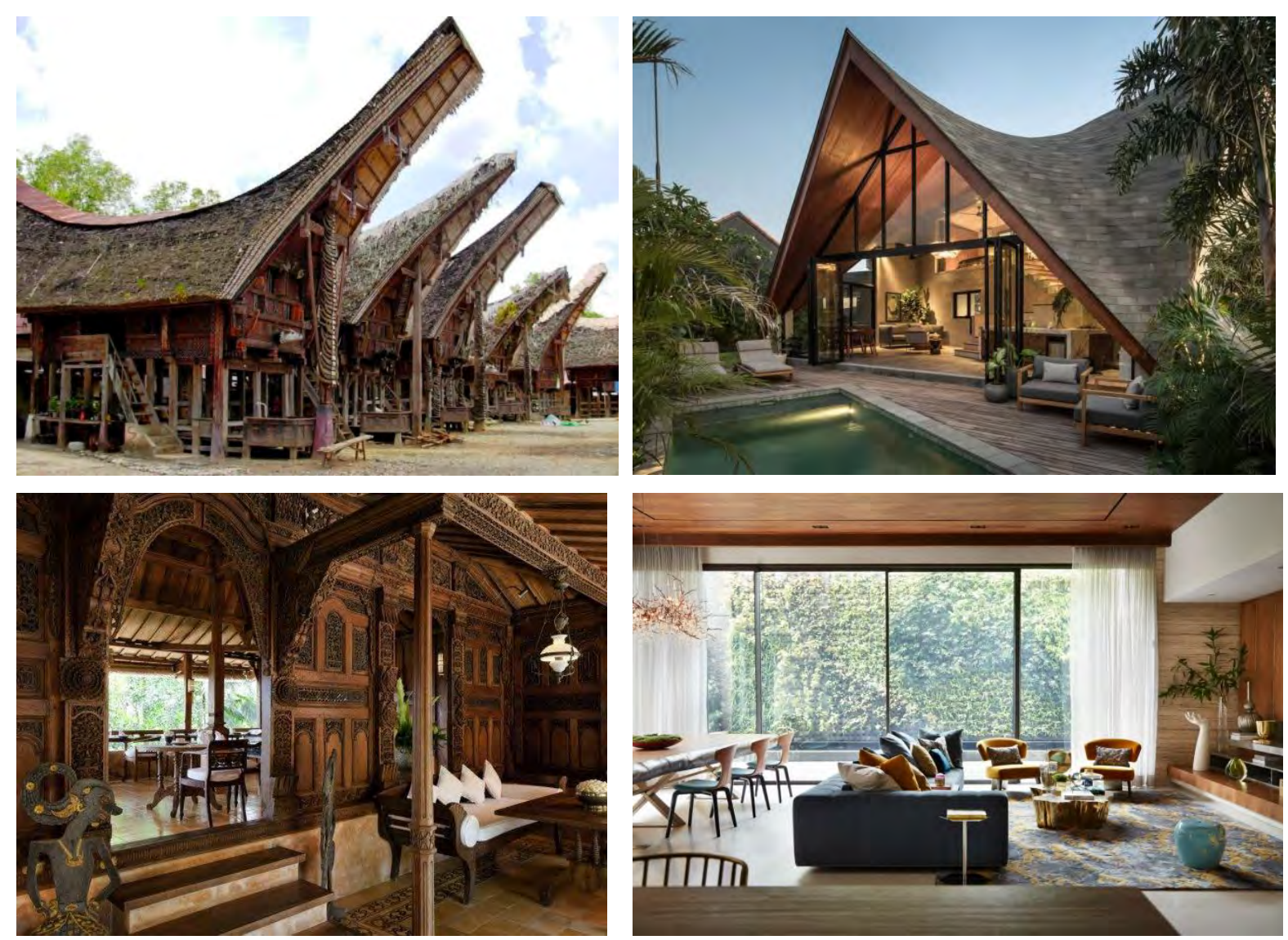

Сл. 11. - 14. Раскошни индонезиски ентериер и екстериер и поедноставени варијанти од ucmume 


\section{4 Локални интерпретации}

\subsection{1 Аркадна традиција - проф. М-р. Ладислав Цветковски}

Голем број македонски уметници и мали студија го насочуваат својот фокус кон реинтерпретирањето на македонската традиција и култура во нивните дела. М-р Ладислав Цветковски, професор на Факултетот за ликовни уметности, незадоволството од манипулативната природа на политичката сфера ја преплетува со фолклорни мотиви во серија дигитални принтови. И покрај политичката порака, визуелната инспирација позади овие дела се токму мотивите од македонските традиционални везови, носии и черги.

Освен визуелната порака, во колекцијата на Цветковски се преточуваат два важни аспекта од македонската култура, раскажувањето и историјата [23]. Низ долговековната историја на македонскиот народ, постојаниот политички конфликт, окупаторскиот немир, војните, се создава посебна врска меѓу човекот и делото, односно меѓу создавачот и визуелизацијата на неговата мисла, чувства, емоции. Дигитализацијата, во случајот на делата на Цветковски, е новиот стадиум на изразување и споделување на приказни од испревртеното секојдневие на еден современ човек.

Во делата се препознаваат елементи и принципи кои се препознатливи за македонските фолклорни креации како ритмичноста, едноставните геометриски форми, следењето на унифицирана насока и контрастот форма наспроти позадина (сл.15. и 18).
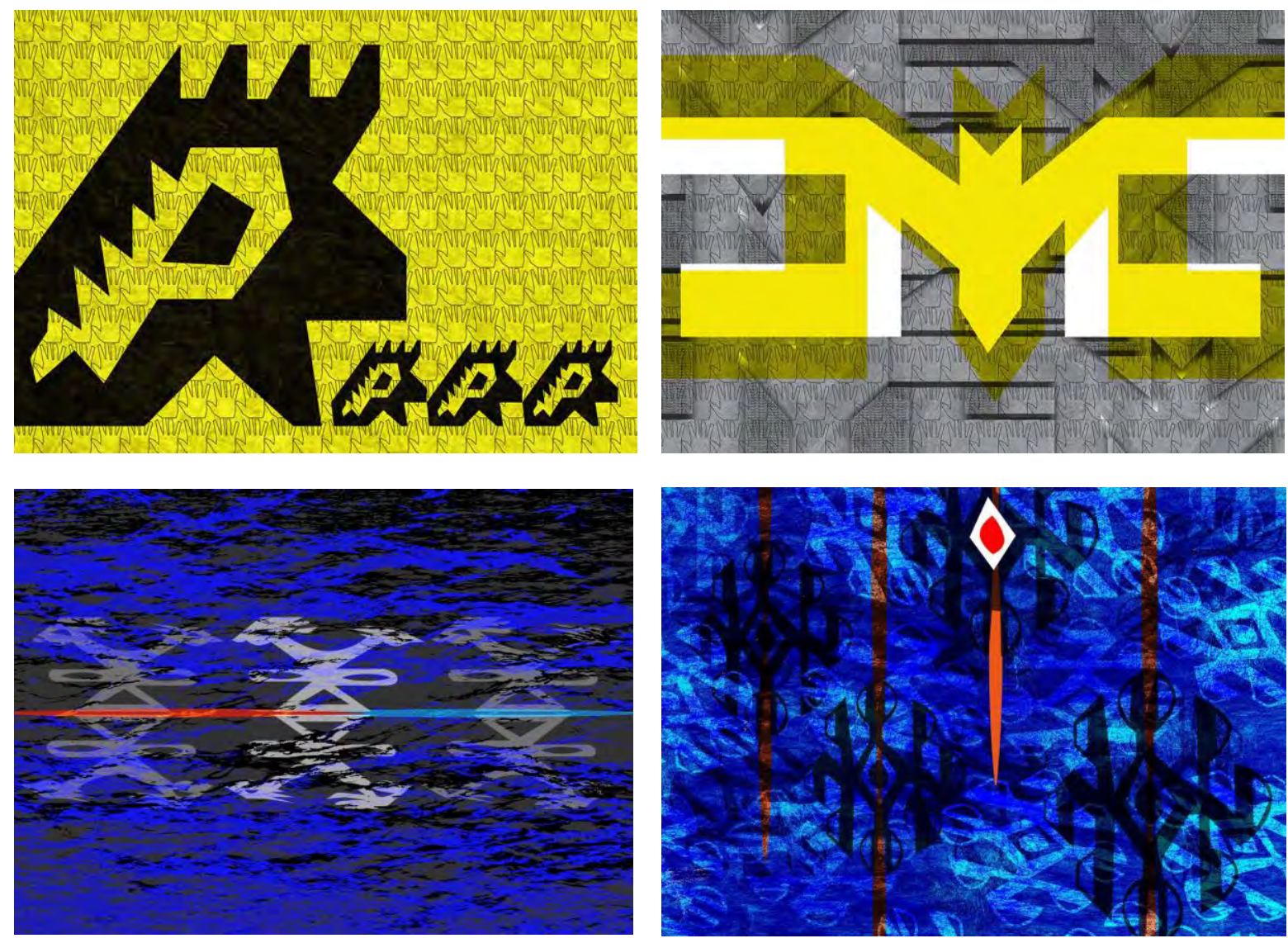

Сл. 15-18 Одбрани дела од Аркадна традиција (1) Храна (Кодошот ги јаде своите копилиња), (2) Уво (малиот брат слуша), (3) Поплавена иднина, (4) Постојана миграција, 


\subsection{2. Комрад Дизајн / Komrad Rug - Дијана Томиќ Радевска}

Од 1993-та година, Дијана Томиќ Радевска и Марин Радевски, работат под името Комрад Дизајн [24] и изработуваат дизајнерски килими со реинтерпретирани фолклорни шари. Главна карактеристика на овие килими е современиот изглед во согласност со дизајнерските трендови и задржувањето на традиционалниот начин на изработка. Единствените парчиња дизајнирани од Томиќ се рачно изработени, некои според персискиот јазол во кој, доколку е точно и прецизно изработен, може да се избројат околу 120000 јазли на квадратен метар.

Мултикултурноста и воедно и мултиетничноста на оваа територија е присутна и изразена карактеристика во дизајнирањето на килимите. Македонската традиција поради долгогодишни влијанија од други култури, има преземено и усогласено различни ориентални, отомански, хеленски и многу други принципи низ вековите. Со тоа, македонската традиција носи мултиетнички елементи соодветно адаптирани на македонските обичаи и карактеристики.

Во килимите на Томиќ тоа се доловува преку комбинирање на техниката со формите. На пример, доколку формите се реинтерпретација на формата преземена од предното платно на носијата, техниката на изработка може да биде персиска. Или обратно, формата на килимот може да алудира на килим од персиско потекло, додека изработката е со македонска техника. Од дизајнерска гледна точка, во дизајните на Томиќ се кршат одредени правила и елементи, се намалува бројот на форми и се зголемува празниот простор (сл.19. - 22.). Доминацијата се намалува од неколку елементи на само еден и се препознаваат само формите или пак само линиите.
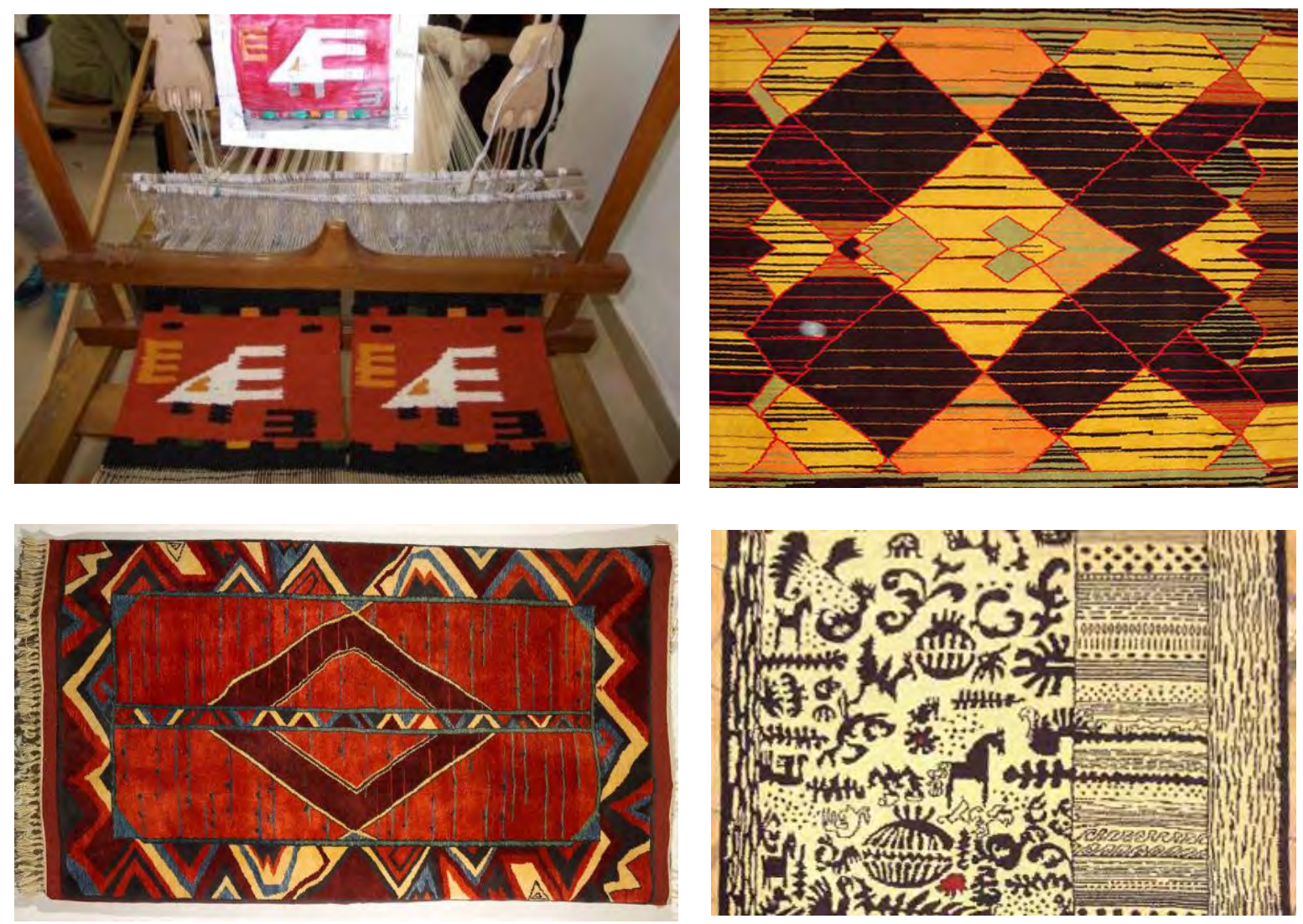

Сл.19. - 22. Одбрани дела на Дијана Томиќ Радевска и начинот на изработка 


\subsection{3 Артерија - Европски универзитет}

Студентите и професорите од Европскиот универзитет, во рамките на Факултетот за арт и дизајн и под менторство на проф. Јана Манева Чупоска го преточуваат македонското културно наследство во современ моден дизајн. Целта на проектот Артерија [25] е пречистувањето од деталите и пренатрупаноста од елементи и сведување на фолклорот на ниво на самата срж на културниот идентитет. Кај студентските креации, присутно е вметнувањето на поедноставените елементи во веќе посовремен контекст, додека кај професорските е присутна реинтерпретацијата. Исто така, се крши формата во целост, но се задржуваат ритмичноста, симетријата, рамнотежата и хармонијата. Новите поедноставни дезени се префрлуваат на едноставни еднобојни контрасни површини со што доаѓаат до израз.

Перформансот и дизајните на Чупоска го имаат истото ниво на едноставност, но ги задржуваат доминантните бои од носиите. Металните елементи се заменети со дрво или пак се вметнати во дизајнот како форма (сл.23. - 27).

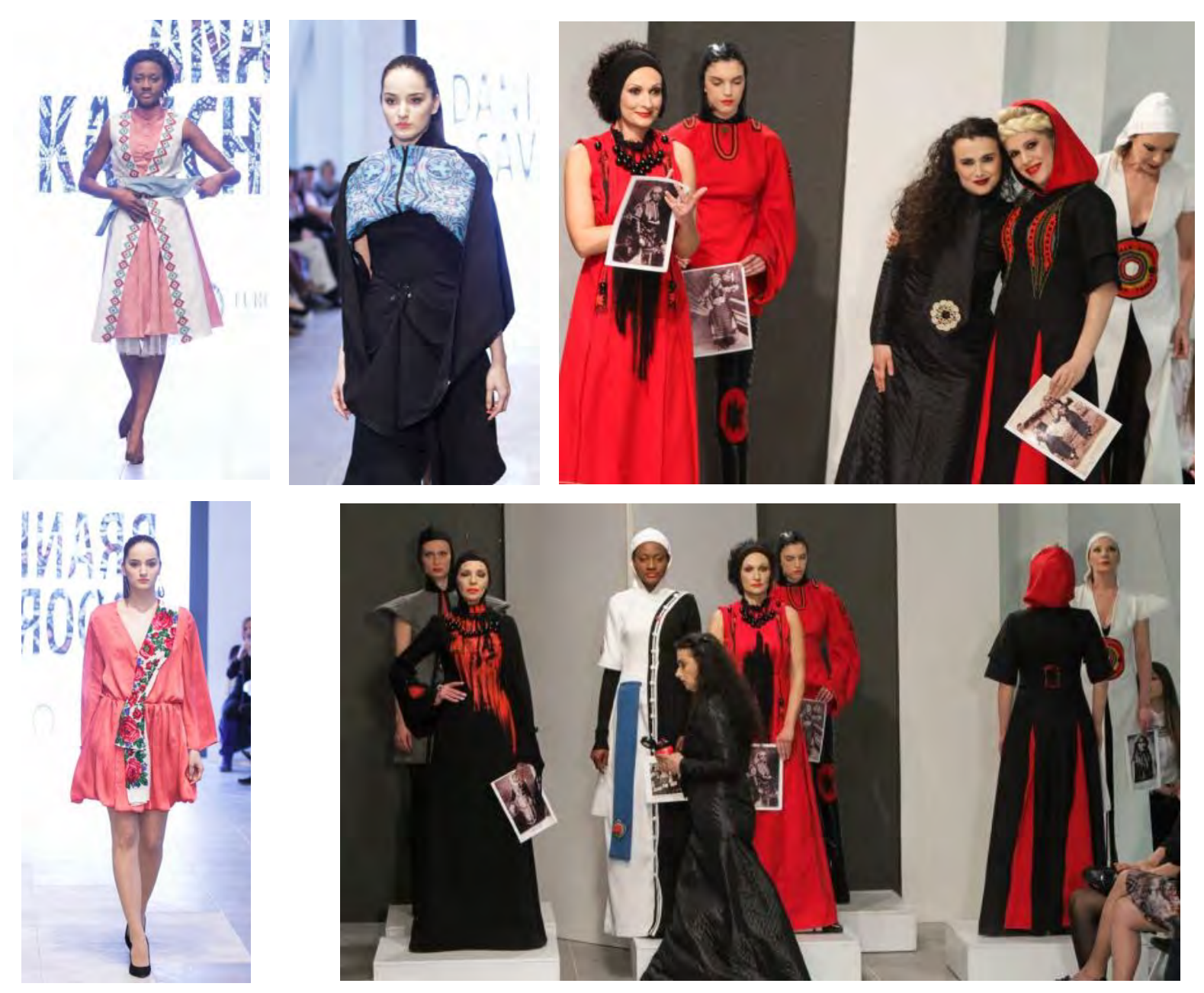

Сл. 23. - 27. Студентските дела на модната ревија и делата на Јана Манева Чупоска 


\subsection{4 Синтезис и Александар Ношпал}

Етно групата Синтезис е позната по нивните препеви на македонските народни песни и нивните авторски дела во етно стил. Автентичноста на македонското културно наследство се доловува со присуството на препознатливи инструменти од народните песни како гајда, дудук, кавал, зурла, дајре и други. Освен музичката реинтерпретација на фолклорот, сценскиот настап и костимите на групата се дизајнирани според македонските носии од страна на Александар Ношпал. Меѓу креациите на Ношпал се препознаваат и други дизајни кои се директно инспирирани од македонскиот фолклор.

Дизајнот на текстилните делови од реинтерпретираните носии е многу поедноставен, но контрастот, динамиката, визуелната рамнотежа и препознатливата ритмичност се присутни во накитот, односно во огрлиците, обетките и металните токи (сл.28. - 30.).
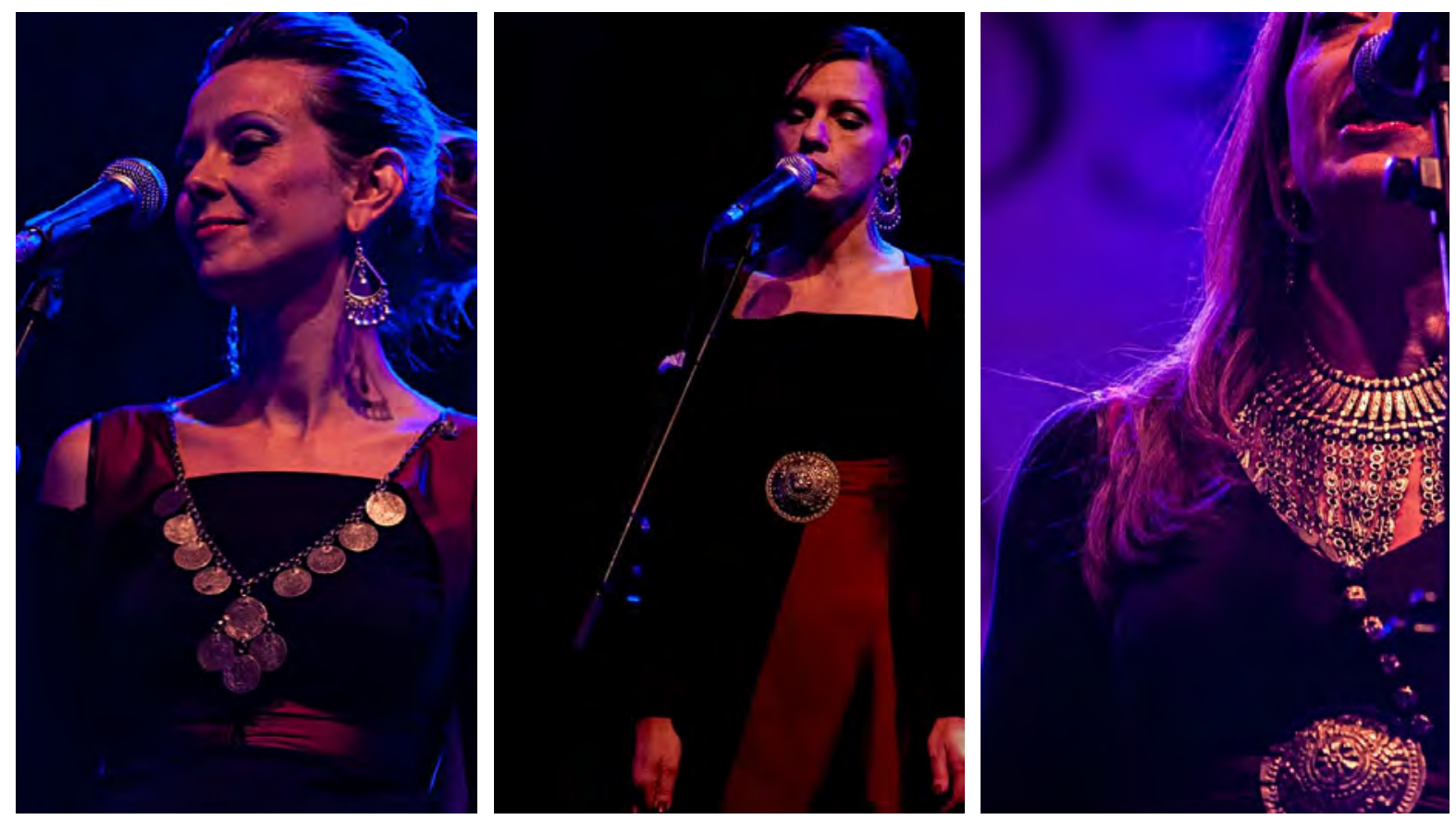

Сл. 28-30 Членовите на Синтезис и нивните костими инспирирани од македонската традиционална носија

\section{5 Заклучок}

Македонската традиција имала многу силно влијание од византиската, а потоа и турската култура, поради петвековното творештво создавано во периодот на Отоманската Империја. Влијанија се чувствуваат и од периодот поминат во рамките на државата Југословија. Слоевитоста на разновидните култури поради периодичните влијанија во текот на македонската историја се отсликува во животните навики на македонскиот народ. Конкретен пример се Бадниковите огнови и прославата на Коледе, пагански обичаи кои преживеале и покрај преминувањето кон христијанската вера.

Како релативно млада држава, со преземање на позитивните досегашни стереотипи околу македонската култура и природа и комбинирањето со нови методи и техники во дизајнот, постои можност да се создаде нов бран посакувани и препознатливи локални производи. Истите не само што би биле зајакнување на културната припадност во домот, туку ќе можат да се 
интегрираат и во домовите на странските туристи исполнувајќи ги функциите на паралелните модерни барања.

Проширувањето и информираноста околу новосоздадените производи и можната западна афирмација преку соодветна маркетинг стратегија можат да бидат посигурно прифатени од домашната култура. Модерната реадаптација бара и модерен пристап за промоција со цел да се освои повеќе и локалниот пазар. Основата што ја има македонското културно наследство и неговата поврзаност со природата, доколу соодветно се реадаптира во современ изглед, има можност да се пробие на светската дизајнерска карта. Моментално главни трендови при презентирање и пласман на одредени производи се: самото подигнување на локалната свест и потреба за идентификување; создавањето производи што имаат многу блиска поврзаност со природата и поминуваат низ минимален процес на преработка и создавање отпад; етно инспирирани мотиви и самоодржливост. 


\section{3. Истражување на постоечка литература од областа на естетиката}

Естетиката се манифестира со задоволувањето на човековите сетила. Сетилата за вид, звук, допир, вкус и мирис, надополнети со чувствата и искуствата, придонесуваат кон одлуката дали врската меѓу корисникот и производот ќе биде позитивна или негативна. На пример, при избор на една тастатура, корисникот ќе се потпре на сопствените очекувања и искуства при ракување и ќе одлучи дали таа тастатура создава добар тактилен фидбек при употребата, дали копчињата се добро распоредени, дали боите се привлечни итн. Сите овие информации може да се квантифицираат во разбирлив дизајнерски јазик, односно во дизајнерски елементи и принципи.

Корисникот е способен, не само да ги идентификува составните дизајнерски елементи кои се присутни во производот со кој има интеракција, туку и потсвесно да препознае врски меѓу елементите кои ги перцепира. Корисничкото искуство е единство на задоволување на сетилата, значајно интерпретирање и емотивно внесување [3]. Естетиката во индустриските производи наведува дека повеќе внимание е посветено при дизајнирањето на истиот, за да може да се воздигне визуелната допадливост и притоа и функцијата ќе биде истрајна и соодветна.

Многу аспекти се земаат предвид при изборот на еден производ, но едно од поважните барања е естетската компатибилност меѓу корисникот и прозводот, дали естетските информации ќе содејствуваат со очекувањата и искуствата на корисникот, дали производот ќе ја достави пораката што корисникот треба да ја разбере. Традицијата ја разбираат конкретна група луѓе кои меѓусебно делат долгогодишно развиени обичаи и верувања.

При анализирањето еден производ се разгледуваат три дизајнерски карактеристики: формата, композицијата и физичките атрибути [5]. Во дизајнот треба да се земат не само визуелните карактеристики на предметот туку и просторните. Во зависност од предметот на анализирање може да бидат разгледани и други карактеристики на естетиката како стил.

Естетиката може да се анализира со идентификувањето на елементите и разбирање на принципите применети во одредено конкретно дело. Тие се составните делови на обликувањето на предметот и одредуваат на каков начин тие делови комуницираат меѓусебно. Дизајнерските елементи што ќе бидат извлечени од разгледаните предмети во овој труд се:

1. Линија - основна градбена единка, издолжена точка или форма, движечка сила на вниманието на гледачот, првостепен носител на карактерот на композицијата, прв впечаток;

2. Форма - површина дефинирана од отворени или затворени линии, површина, облик, второстепен носител на карактерот, тесно поврзан со карактерот на линијата;

3. Боја - препознавање на вредностите од светлинскиот спектар;

4. Материјал - од што е изработен предметот;

5. Текстура - површинска тактилна или визуелно симулирана (имитирана) препознатлива површина;

6. Насока - визуелната сила што го одредува движењето на окото на набљудувачот и ги следи линиите и формите, ги поврзува и усогласува елементите кон поконкретни ставови и чувства; 
7. Големина - елемент што ја дефинира релативната врска меѓу другите елементите, елемент што ги води другите и споредбата започнува од него.

Дизајнерските принципи се уште еден дел од дизајнерскиот јазик што помага при идентификување на релациите меѓу елементите. Иако елементите можат да имаат индивидуални карактеристики, како тие функционираат во однос на целата композиција зависи од применетите принципи [5]. Дел од тие принципите ќе бидат анализирани во понатамошното истражување во рамките на овој магистерски труд:

1. Хармонија - дали елементите соработуваат едни со други и до кој степен;

2. Контраст - кои елементи имаат спротивни карактеристики, елементи кои имаат поголема разлика во нивните карактеристики создаваат поголем контраст;

3. Пропорција - споредба на елементите во композицијата, нивната мерливост;

4. Ритам - дали некои елементи се повторуваат, дали тие елементи што се повторуваат ги менуваат карактеристиките или остануваат исти;

5. Движење - во која насока се движат елементите;

6. Рамнотежа - дали композицијата подеднакво тежи, дали елементите меѓу две групи се визуелно симетрични или пак се асиметрични;

7. Едноставност - дали композицијата има многу или малку елементи, дали елементите се едноставни или комплексни;

8. Доминација - што е најприсутно во композицијата, кои елементи се подоминантни, која група или карактеристика на елементите е повпечатлива;

9. Единство - дали елементите и принципите се правилно поставени, дали сите тие соработуваат во композицијата;

10. Композиција - како се распределени елементите.

Како надополнување на дизајнерски фокусираните информации околу естетиката на еден производ, значајно место има и примената на Гешталт принципите. Тие ја согледуваат целината наспроти индивидуалните елементи и се поврзуваат со човековата љубопитност, креативност, потреба да ги внесат сопствените искуства и барања во делото што го перципираат. Макс Вертхајмер [6], во неговата книга „Теорија на формата“ прикажува точки во простор во кои што гледачот распознава слики и врски. Зависно од блискоста, сличноста, континуитетот и организацијата во просторот, одредени елементи делуваат посродно во однос на други како резултат на потребата на препознавање на шарите во хаотична композиција. Луѓето несвесно создаваат силна врска меѓу себеси и делото, доколку делото ги исполнува нивните потреби [7]. Такви се следните принципи:

- фигура-позадина - распознавањето на фигура наспроти позадина, полн наспроти празен простор, објект врз основа, елемент на фокус наспроти фигура врз која е поставена;

- $\quad$ површина - при преклопувањето на една форма врз друга, таа што е во прв план ќе се перципира како фигура, додека таа во втор план како позадина;

- сличност - разновидни елементи во една композиција може да се сметаат за поповрзани доколку делат заеднички елементи, како слична боја, форма, насока;

- униформна поврзаност - и покрај тоа што одредени елементи имаат одредена визуелна сличност, поповрзано делуваат елементите што се визуелно меѓусебно поврзани и имаат конкретна врска како линија, круг или друга форма; 
- континуитет - елементите кои се поставени долж некоја права или крива линија се перципираат како поповрзани, независно од тоа дали имаат сличности со други форми во композицијата;

- $\quad$ затвореност - неповрзаните елементи кои делуваат како да се дел од некоја целина и тенденцијата истите имагинарно да се поврзат;

- близина - визуелното ажурирање на елементите, поточно празниот простор меѓу истите, дозволува полесно да се препознае која форма е складна со некоја друга, независно од нивните индивидуални атрибути;

- заедничка судбина (синхронизација) - индивидуални елементи кои следат одредена заедничка насока делуваат посродно отколку два исти елемента кои не следат иста патека на движење;

- симетрија - тенденцијата за потрага на огледалните форми во една композиција;

- $\quad$ паралелизам - паралелни линии или паралелни судбини на форми создаваат чувство на поголема поврзаност;

- заеднички регион - елементите се стремат да бидат групирани дококу нивната поставеност е во затворен простор;

- минато искуство - искуствата, сеќавањата, чувствата играат голема улога во перципирањето, потребата за препознавање на работи од претходни искуства;

- закон на фокална точка - точка на интерес, акцент во композицијата;

- закон на едноставност - двосмислени, комплексни форми, полесно се разбираат кога ќе се поделат на полесно разбирливи делови.

Разбирањето на Гешталт принципите помага при разбирањето зошто една композиција е поестетска во однос на друга. Колку повеќе во една композиција се опфатени овие принципи, толку истата може да биде попривлечна за гледачот. Овие принципи играат голема улога во разбирањето и проучувањето на композициите на македонските фолклорни творби. Таков е примерот со носиите кои содржат форми, линии, насоки и бои, но истовремено истите се соодветно организирани во униформна композиција што ја доловува ритмичноста на македонската музика. При разгледувањето на композицијата од страна на гледач што е запознаен со македонската култура може да се препознае ритам што е соодветен со тактовите и повторувањата во народните песни и танци.

Во контекст на создавањето на формата, Али и Лием [7] од Одделот за дизајн на производи при Норвешкиот универзитет, потенцираат дека е многу важно да се разберат временската рамка во која се дизајнира и трендовите. Тие сметаат дека најчестите две причини поради кои што се започнува со еден дизајнерски процес се: технолошкиот напредок (како може одредено технолошко откритие да се имплементира во дизајн) и задоволувањето потреба (што му недостасува на корисникот што може да се реши со индустриски дизајн). Од овие две причини произлегува дека при аплицирањето на оваа методологија, доколку фокусот е корисникот и неговите потреби, мора да се има предвид:

- кому му е наменет дизајнот?

- дали корисникот ќе може да го разбере дизајнот?

- дали дизајнот ќе содејствува со очекувањата и барањата на корисникот?

Низ вековите, човековата љубопитност и потрага кон врските меѓу нештата и квантифицирање на истите, има придонесено кон многу закони на математиката, а вооедно и 
уметноста, како: златен пресек, Фибоначиева низа, правило на третини, Хиков закон, Фитов закон итн. Според Али и Лием [7] , психологијата на перципирањето и физиката се информации кои придонесуваат кон преведувањето / преминот кон на естеските карактеристики.

Пам од Универзитетот во Балард, Австралија, предложил информатичка методологија во вид на систематски пристап за истражување на интеракциите на естетските својства и променливите на дизајнот, преку интегрирање знаења од други области, како што се филозофијата, психологијата и уметноста. Вообичаено прифатените естетски својства и јазичните термини што се користат за оценување на дизајнот најпрво се дискутираат, а потоа се идентификуваат девет принципи за постигнување естетски производи во голем број креативни дисциплини.

Бернард Чуми, познат по неговиот придонес во деконструктивизмот во 60-тите и 70-тите години, феномените и интеракциите меѓу луѓето и нештата ги сведува на основни единки за градење средини и простори. Поточно, тој разгледува ситуации и истите ги сведува на неколку основни градбени елементи како што е претставено во збирката The Manhattan Transcripts [8] од 1981.

Презентираните истражувања на постоечката литература од областа на естетиката беа неопходни за подобро разбирање на суштината на естетиката кај производите, преку проучување на основните градбени единици и принципи, Гешталт принципите и целокупната семантика. Притоа беа препознаени конкретни истражувачки достигнувања кои беа земени како основа во создавањето на стратегијата за разработка и анализа на македонските традиционални производи. 


\section{4. Методологија за извлекување градбени елементи за}

\section{визуелниот идентитет на македонската традиција}

Истражувачкиот дел на оваа магистерска работа има цел да ги примени заклучоците изведени од разгледувањето и анализирањето на методологиите на реинтерпретација на дизајнот во дела со друг културен идентитет во проучување на локалните традиционални предмети од македонското поднебје, да ги проучи нивните естетски квалитети и особини и да изнајде начин како тие да бидат достапни како метод за инспирација во креирање модерни дела во сите области на дизајнот и архитектурата.

\section{1. Научна подлога}

Научните сознанија во областа на естетиката во дизајнот на производи, презентирани во претходното поглавје, овозможија да се препознае научниот пристап кој е најсоодветен за примена во конкретното истражување. Двонасочниот процес за разбирање и дизајн за естетика на Пам од Универзитетот во Балард, Австралија [5] е земен како основа на целокупната стратегија за примена на препознаените естетски карактеристики на македонските традиционални предмети како инспирација во дизајн на нови производи, во кои ќе биде применет визуелниот идентитет на македонската традиција.

Основата на процесот на дизајнирање и разбирање, според Пам [5], има цел да ги идентификува психолошките потреби на корисникот, односно неговите чувства и емоции при разгледувањето на едно уметничко дело и корисничкиот однос со производот. Низ историјата, главните анализи на естетика се базирани врз визуелната уметност, музиката и литературата. Но, заради временскиот контекст на разгледување и воведувањето на уметностите во применливи производи, потребно е активно да се разгледува предметот како уметничко дело и како производ со цел да биде понуден на пазарот и продаван.

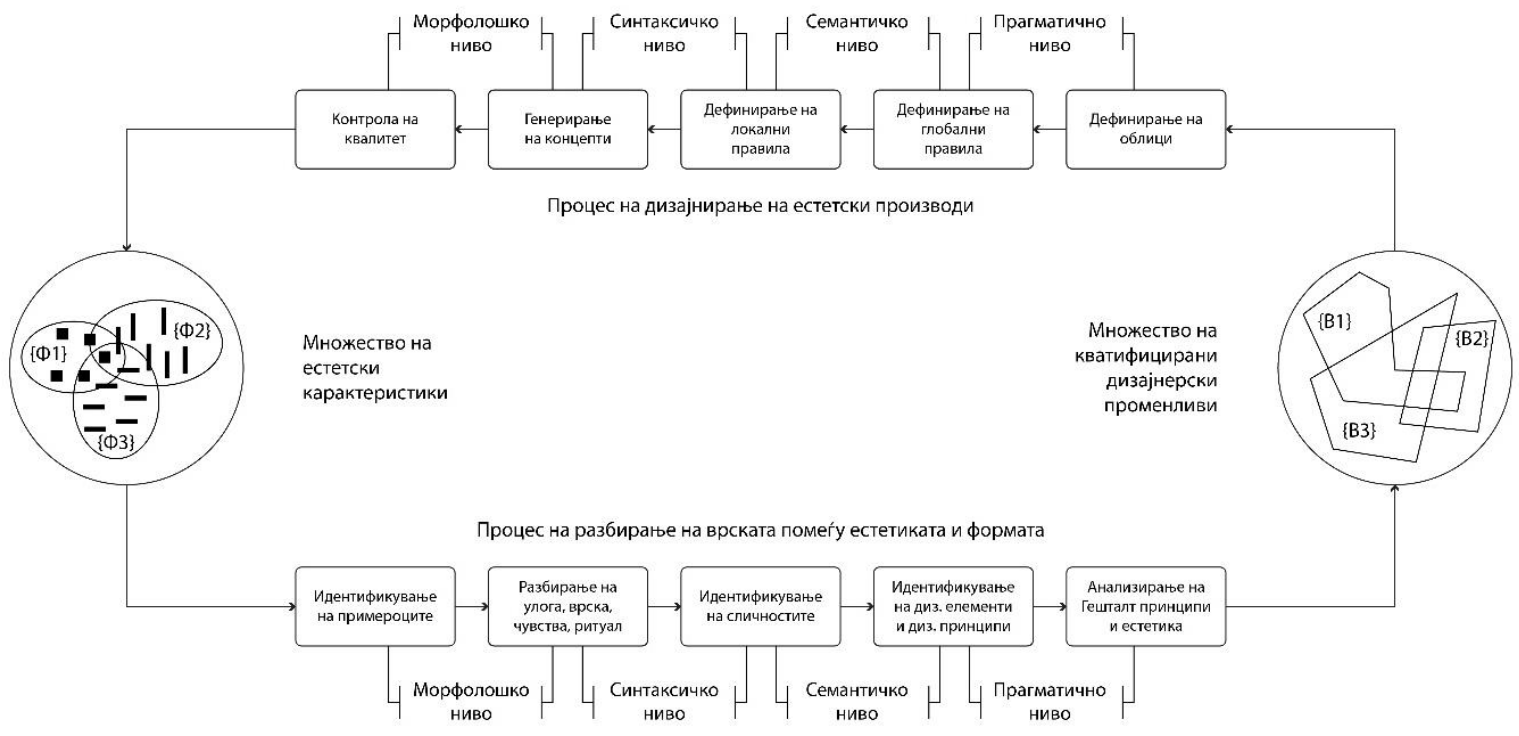

Дијаграм 1 - Двонасочен прочес на дизајнирање и идентификување естетски карактеристики, според Пам [5] 
Процесите на разбирање на врската меѓу естетиката и формата и процесот на дизајнирање естетски производи чинат еден комплетен круг. Циклусот може да биде употребен за неколку цели:

1. Да се извлечат заклучоци околу естетските карактеристики на едно множество производи и нивно квантифицирање [половина циклус, со почеток од конкретни предмети];

2. Да се дизајнира естетски производ од веќе донесени дизајнерски променливи [половина циклус, со почеток од променливи];

3. Да се дизајнира нов асортиман естетски производи од произволен извор како природа, фолклор [цел циклус, префрлување естетски карактеристики од една форма во друга];

4. Да се редизајнира веќе постоечки асортиман производи преку извлекување естетски карактеристики [цел циклус, редизајн со преточување во естетика].

Пам предложил информатичка методологија во вид на систематски пристап за истражување на интеракциите на естетските својства и променливите на дизајнот, преку интегрирање на знаења од други области, како што се филозофијата, психологијата и уметноста. Вообичаено прифатените естетски својства и јазичните термини што се користат за оценување на дизајнот најпрво се дискутираат, а потоа се идентификуваат девет принципи за постигнување на естетски производи во голем број креативни дисциплини.

Во случај на исполнување на еден целосен циклус на преточување во естетски карактеристики, испитуваните примероци можат целосно да се разликуваат во споредба со крајните предмети. Може и по комплетирањето на еден циклус, крајниот заклучок да не биде строго индустриски дизајн, туку може да биде и друг тип уметност.

Потоа се врши анализа на начинот на кој овие принципи влијаат врз карактеристиките на производот и се извлекуваат конкретни и пресметливи својства на производите што можат да бидат различни, со цел да се предизвикаат различни естетски проценки и одговори [5].

Деконстуктивизмот на Чуми [8] е прифатен како пристап во проучувањето $и$ презентирањето на градбените единки на естетиката, поточно дизајнерските елементи и принципи на избраните примери за анализа на македонските традиционални производи (сл. 31).

Бернард Чуми, познат по неговиот придонес во деконструктивизмот во 60-тите и 70-тите години, феномените и интеракциите меѓу луѓето и нештата ги сведува на основни единки за градење средини и простори. Поточно, тој разгледува ситуации и истите ги сведува на неколку основни градбени елементи како што е претставено во збирката The Manhattan Transcripts [8] од 1981. Градбените елементи имаат цел да доловат еден настан во конкретен период и наместо преку разгледувања на просторот, движењата, размените и конфликтите на субјектите и преработка на истите, да се реалиизраат преку создавање програм, поточно начин на којшто ќе функционираат овие единки во нова целина со нова намена. Иако процесот на разработка на овие информации е наменет за употреба во архитектурата, истиот може да се примени на сосема нов начин на други дизајнерски процеси. 

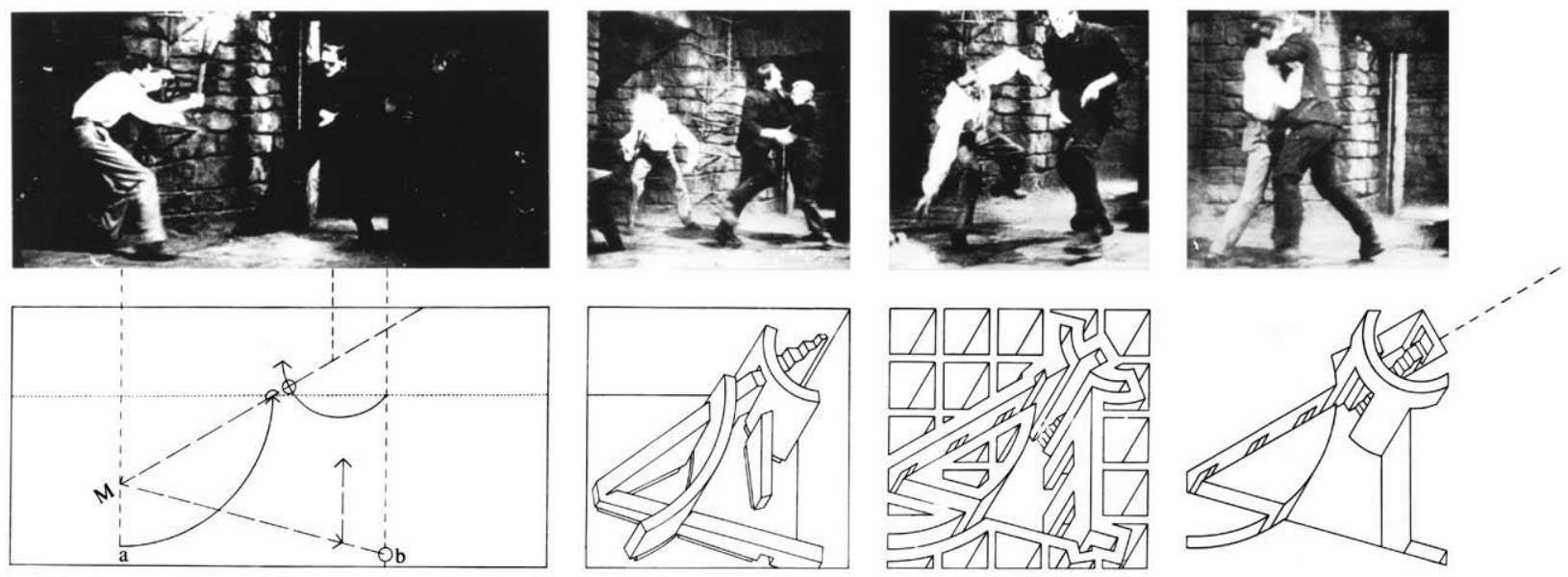

Сл. 31 Деконструкција на акција во просторот - Manhattan Projects

Иако Чуми префрла основа на еден медиум во основа на друг медиум, поточно филм во архитектура, контекстот од оригиналната приказна може да се почувствува во новата интерпретација. Истото може да се изведе во еден медиум, поточно субјектот на оваа магистерска теза, македонскиот фолклор. Доколку се дефинира основа по урнек на предмет од минатото, истата може да се употреби за да се создаде нов предмет во современиот контекст.

\section{2. Утврдување чекори на методологијата}

Врз основа на заклучоците од претходните анализи на постоечки истражувања од областа на естетиката, дефинирана е стратегијата за истражувачкиот процес која се состои од неколку чекори (Дијаграм 2):

- Собирање, селекција и класифицикација предмети за анализирање - одбрани примероци од македонското традиционално/фолклорно творештво;

- Анализа и проучување на применети дизајн елементи и принципи кај избраните примероци со цел да бидат понудени во вид на транслативни членови;

- Процесирање на информациите заради креирање морфолошки матрици;

- Примена на морфолошките матрици со крајна цел - алтерации на транслативните членови заради инспирација за нови производи.

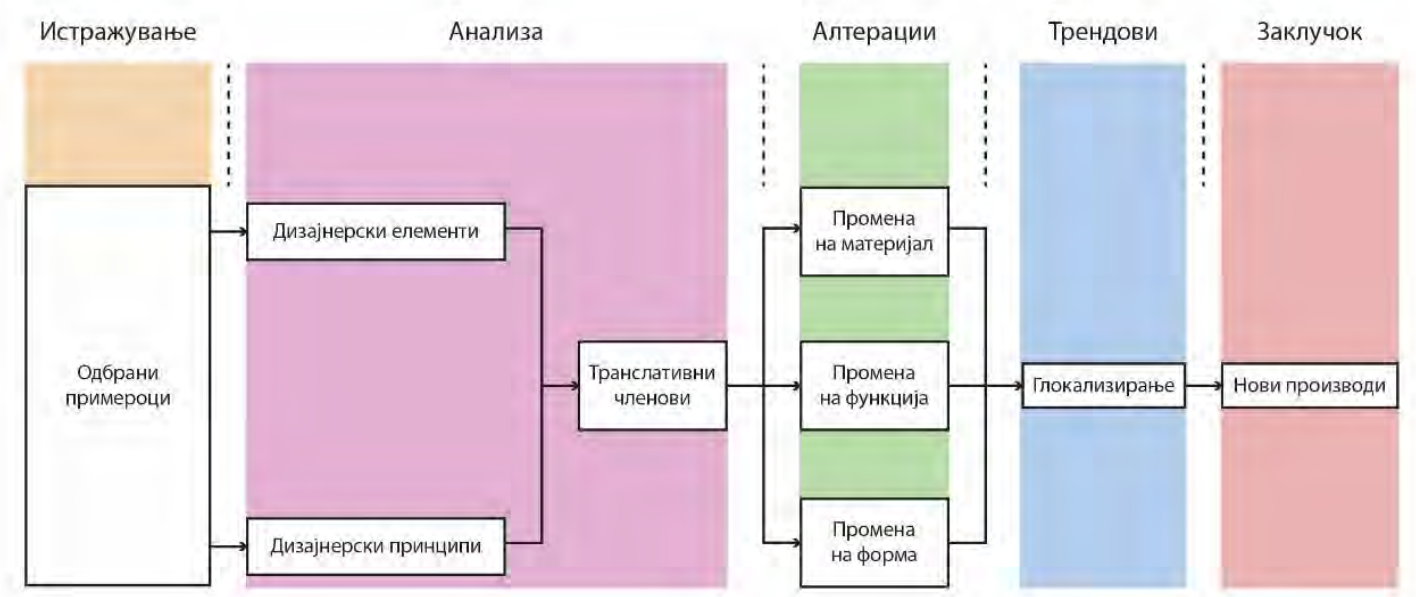

Дијаграм 2 - Стратегија на истражувачкиот процес 


\section{3. Утврдување начин на процесирање на информациите}

Со извлекувањето на дизајнерските елементи и дизајнерските принципи, се квантифицираат градбените единки и може полесно да се разберат темелите на естетиката на предметите. Препознавањето на естетиката и применетите Гешталт принципи во дизајнот на македонските традиционални производи има цел да се препознае суштината на тоа како овие предмети стимулираат одредени чувства кај корисниците.

Со анализирање на македонските традиционални предмети, преку основните дизајнерски елементи и принципи, може да се дефинираат новите градбени единки и врски кои ќе имаат можност да се употребат во современ контекст. Преку прегледувањето на карактерот на линиите, геометријата на формите, контекстот во просторот, генералната насока на линиите и формите, нивната големина, пропорција, рамнотежа, единство, композиција и ритам, може да се препознае подобро суштината на естетиката кај традиционалните предмети од македонското поднебје. Целта е да се создаде база од карактеристични градбени единки и принципи произлезени од македонската традиција од која ќе можат да бидат генерирани идеи за современите производи. Оваа методологија ја усвои алатката „морфолошка матрица“ како најсоодветен начин на систематизација на извлечените карактеристики, со цел тие да бидат јасно класифицирани и визуелно достапни за остварување на крајната цел - алатка за инспирација со елементите на визуелен идентитет на македонската традиција.

Табела 1 - Структура на морфолошка матрица со дизајн елементи извлечени од пет категории производи од македонската традиција

\begin{tabular}{|c|c|c|c|c|c|}
\hline & E1 & E2 & E3 & E4 & E5 \\
\hline ЛИНИЈА & $+\therefore, \geqslant$ & $+\stackrel{!}{-}, \geqslant$ & $+\geqslant$ & $+\geqslant$ & $+\geqslant$ \\
\hline ФOPMA & 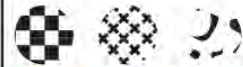 & 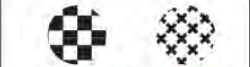 & 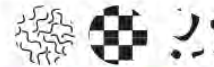 & 9. & 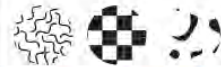 \\
\hline БOJA & & & & & \\
\hline МАТЕРИЈАЛ & & & & & \\
\hline ТЕКСТУРА & & & & & \\
\hline HACOKA & & $1 \|=\frac{1}{\rho}$ & $=\frac{1}{\rho}$ & $y=\frac{1}{2}$ & $=\frac{1}{2}$ \\
\hline ГОЛЕМИНА & 111 & II & III & 1 & IV \\
\hline
\end{tabular}

- МЕТАЛ
ГЛИНА
- ДРВО
- ТЕКСТИЛ

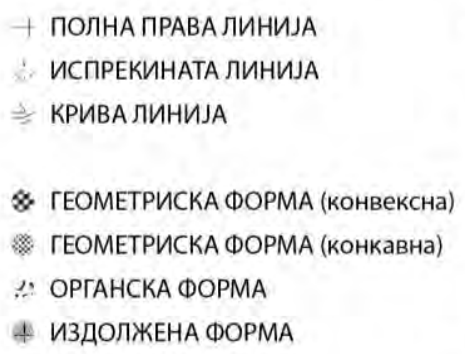

\& ГЕОМЕТРИСКА ФОРМА (конвексна)

ГЕОМЕТРИСКА ФОРМА (Конкавна)

$\therefore$ ОРГАНСКА ФОРМА

4) ИЗДОЛЖЕНА ФОРМА

О ГРУБА ТЕКСТУРА

- MA3НA TEKCTУPA

- РЕЛJЕФНА ТЕКСТУРА

II ВЕРТИКАЛНА НАСОКА

= ХОРИЗОНТАЛНА НАСОКА

" ДИЈАГОНАЛНА НАСОКА

НЕПРАВИЛНА НАСОКА 
Во табела 1 е презентирана структурата на морфолошката матрица со дизајн елементи извлечени од пет категории производи од македонската традиција, во која седумте градбени единици, дизајн елементи (линија, форма, боја, материјал, текстура, насока, големина) се редови во матрицата, а во колоните се презентирани множествата испитувани категории предмети од македонската традиција (носии, килими, грнчарски, метални и дрвени производи).

Во табела 2 е презентирана структурата на морфолошката матрица со дизајн принципи извлечени од петте категории производи од македонската традиција, во која десет градбени единици, дизајн принципи (хармонија, контраст, пропорција, ритам, движење, рамнотежа, едноставност, доминација, единство, композиција) се редови во матрицата, а во колоните се прикажани множествата испитувани категории предмети од македонската традиција (носии, килими, грнчарски, метални и дрвени производи).

Табела 2 - Структура на морфолошка матрица со дизајн принципи извлечени од пет категории производи од македонската традиција

\begin{tabular}{|c|c|c|c|c|c|}
\hline & EI & E2 & E3 & E4 & E5 \\
\hline ХАРМОНИІА & $\pi / \Phi / H$ & $\pi / \Phi / H$ & $\pi / H$ & $\pi / \Phi / H$ & $\pi$ \\
\hline KOHTPACT & $\Phi / E / M$ & $\Phi / 6$ & $\Phi$ & $\bar{T}$ & Ф/H \\
\hline ПРОПОРLИИА & Ф/Златен пресек & (1) & Правипо на 1/3 & & \\
\hline PUTAM & $\Phi_{\text {AMI }} / \Phi_{\text {ROH }} / \Phi_{\text {Ant }}$ & $\Phi_{\text {Ant }} / E_{\text {Ant }}$ & $\Phi_{\mathrm{BOH}} / 5_{\mathrm{ANT}}$ & $\Phi_{\text {KOH }}$ & $\Phi_{\text {ROH. }}$ \\
\hline ДВИЖЕНЕ & $11 /=\frac{1}{0}$ & $1 \|=\frac{1}{2}$ & $=\frac{1}{2}$ & $1=\frac{1}{2}$ & $112=\frac{1}{2}$ \\
\hline РАMHOTЕЖA & $\pi / \Phi / 5+$ Верг. & $\pi / \Phi / 5+$ Верт. & $Л+$ Кружна & Л/H + Кружна & Статичка \\
\hline ЕДНОСТАВНОСТ & $\begin{array}{c}\text { Флора } \\
\text { Геометриски форми }\end{array}$ & $\begin{array}{c}\text { Флора } \\
\text { reomerpиски форми } \\
\text { Лyre }\end{array}$ & Геометриски форми & \begin{tabular}{c|} 
Флора \\
Геометриски форми
\end{tabular} & Геометриски форми \\
\hline ДОМИНАЦИЈА & $\pi / \Phi / H / E / T$ & $ת / \Phi / H / D / M / T$ & $\Phi / 6$ & (1) & $M$ \\
\hline ЕДИНСТВО & $\Phi / H$ & $\mathrm{H} / \mathrm{M}$ & $H / M$ & $H / M$ & M \\
\hline КОМПОЗИЦИЈА & Вертикапна & $\begin{array}{c}\text { Вертикална } \\
\text { Хоризонтална }\end{array}$ & $\begin{array}{c}\text { Кружна } \\
\text { Хоризонтална }\end{array}$ & $\begin{array}{c}\text { Кружна } \\
\text { Вертикална }\end{array}$ & $\begin{array}{c}\text { Вертикална } \\
\text { Хоризонтална }\end{array}$ \\
\hline
\end{tabular}

Л - Линија
Ф - Форма
Н - Насока
Б - Боја
М- Материјал
Т - Текстура
Алт - Алтернативно
кон - Континуирано

II ВЕРТИКАЛНО ДВИЖЕНЕ

= ХОРИЗОНТАЛНО ДВИЖЕЮЕ

" ДИЈАГОНАЛНО ДВИЖЕЮЕ

* НЕПРАВИЛНО ДВИЖЕЮЕ

Анализата понатаму подразбира изнаоѓање на сличностите меѓу градбените единки, со цел да се најдат заедничките карактеристики кои би можеле да бидат прифатени како правила на естетиката на визуелните елементи во македонската традиција. Оваа фаза може да се опише преку дијаграмот 3, каде јасно се препознаваат множествата карактеристики за петте различни категории производи. 


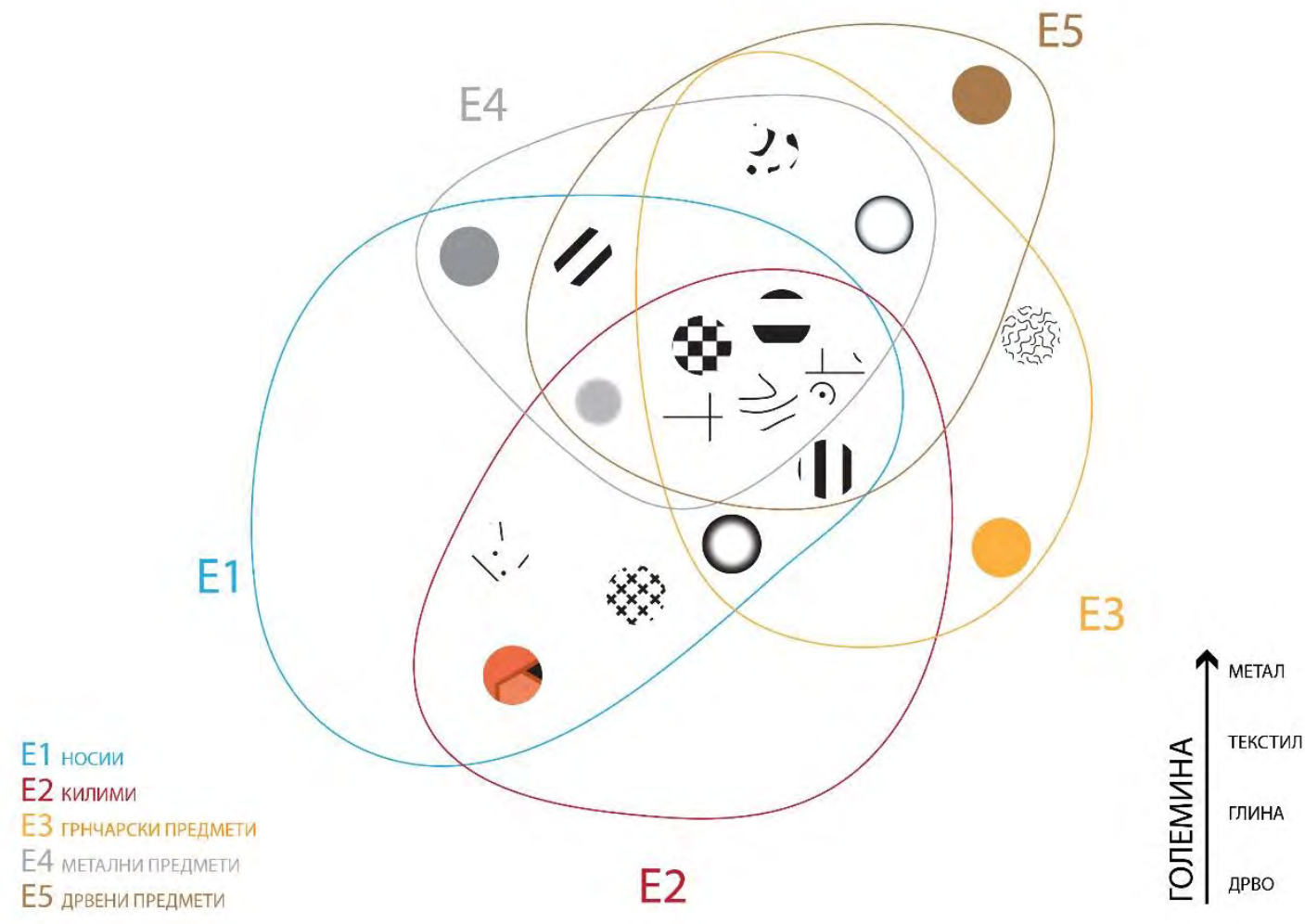

Дијаграм 3 - Сличности и разлики меѓу множествата на петте категории категории производи од македонската традиција

Со разгледувањето на градбените елементи од избраните предмети, нивните сличности и разлики според класификацијата, нивните локални правила и нивните врски, се обезбедуваат можностите за нивни алтерации со цел да бидат применети во дизајн на производи инспирирани од визуелниот идентитет на македонската традиција.

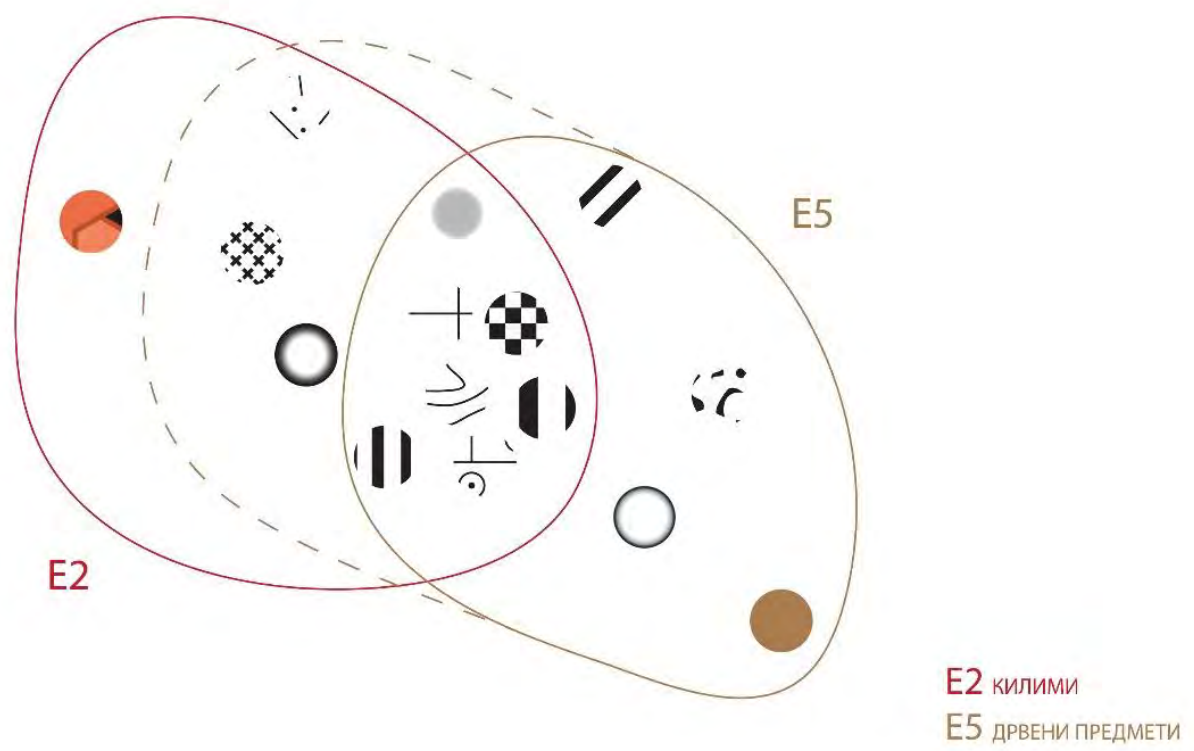

Дијаграм 4 - Комбинирање на градбени елементи од категориите килими и дрвени предмети 
Презентираниот модел на систематизација на извлечените градбени единки на македонските традиционални производи со морфолошка матрица овозможува инспирирање за обликувањето на нов производ со преземање естетски атрибути од две или повеќе множества елементи. Дијаграмот 4 презентира пример со комбинирање на градбени единки превземени од две категории традиционални предмети: килими и дрвени предмети. При тоа може да се комбинираат материјал и текстура од дрвените предмети, форми и насоки од килимите.

\section{4. Препознавање на функционалноста на производите и можноста за алтерации}

Паралелно со процесот на анализирање на градбените елементи на естетиката кај избраните традиционални предмети, се очекува истиот да биде анализиран и од аспект на потребата од задржување или промена на функцијата или формата. Целата постапка е опишана преку дијаграмот 5. Неопходна е идентификација на објектот - дали неговата функција и форма е сѐ уште применлива во современиот начин на живеење. Тука се согледани можности за редизајн на ваквите производи со цел да добијат помодерни карактеристики или пак да се употреби нивната форма со нова функција, или обратно.

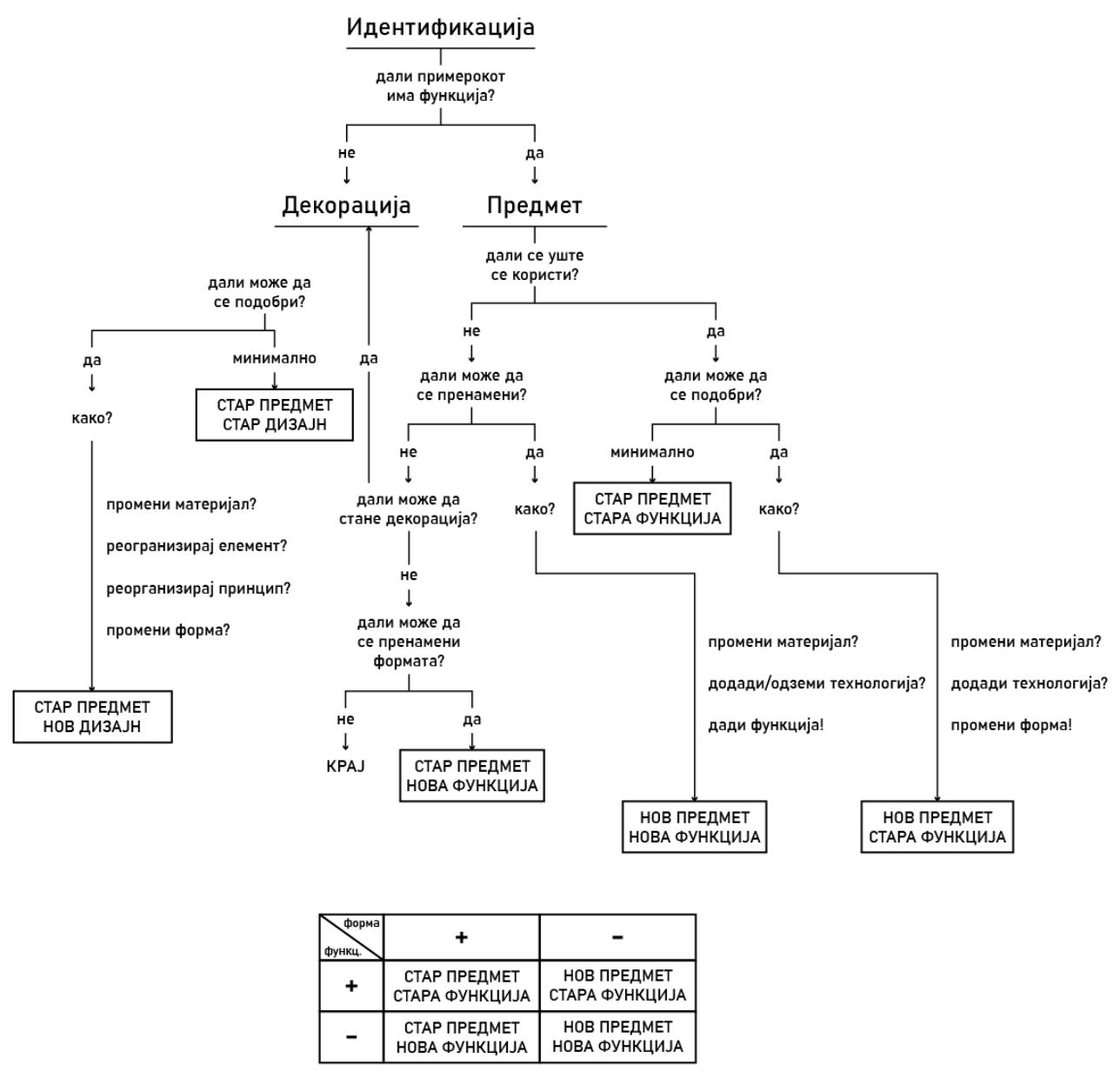

Дијаграм 5 - Алгоритам за анализа на традиционалните производи во однос на потребата од задржување или промена на функцијата или формата 


\section{5. Анализа на обележјата на културниот идентитет во дизајнот на дела од македонската традиција}

Во ова поглавје е презентиран првиот чекор во реализација и примена на утврдената методологија во претходното поглавје. Најпрво е извршена селекција и класификација на предмети од македонската традиција, а потоа е пристапено кон нивно анализирање од аспект на визуелните карактеристики.

\section{1 Собирање, селекција и класифицикација на предмети за анализирање}

Првата фаза во истражувачкиот процес е изборот на предметите со традиционален белег и информации во врска со нив. Со примена на методите на етнографските проучувања, собрани се информации во вид на фотографии, текстови, но и интервјуа со избрани занаетчии и ракотворци, членови на актуелни здруженија, проекти, работилници, кои се занимаваат со македонската традиција. Беше извршено и проучување на научни истражувања од областа на македонската етнологија.

\subsection{1 Извори на информации и собирање примероци}

Почетното собирање примероци за истражување започна со преглед на предметите во домаќинствата низ нашата земја. Истражувањето е извршено со пребарување фотографии на примероци од градовите и селата на нашата земја, објавени на социјалните мрежи од љубители на нашето традиционалното творештво (сл. 32). Истовремено, преку лични контакти и преку социјалните мрежи, беше собрано поголемо количество фотографии и информации околу мислењата и ставовите на нашите граѓани за значењето и естетските квалитети на овие предмети.

Анализата на собраните информации покажа дека желбата за создавање колекции од вакви традиционални предмети и нивна примена во современите домови не е многу изразена кај помладите семејства. Во повозрасните семејства многу предмети сѐ уште се употребуваат, на пример, садови и алатки за приготвување одредени традиционални јадења. Истите сѐ уште можат да се најдат во продажба во старите чаршии и пазари низ градовите.

Ретки се примерите на ентузијасти и вљубеници кои ги уредиле своите домови со автентични македонски традиционални предмети. Но, во последно време се појавија поголем број етно ресторани и конаци уредени во македонски традиционален стил, со желба и намера да привлечат домашни и странски туристи и гости и да им го понудат традиционалниот македонски амбиент во комбинација со вкусните и надалеку познати специјалитети на македонската традиционална кујна.

Македонските ракотворби, од носиите до дрвените резби, покажуваат високо ниво на посветеност на детали, како и многубројни алати потребни за да се изработат истите. Ова покажува колку овие предмети биле од важност во тогашното општество и колку во него било почитувано местото на занаетчиите кои ги изработувале.

Истовремено, освен занаетчиството, многу важен момент околу македонската култура е кујната, поточно земјоделието и традицијата во приготвување на храната. Многубројните житни и градинарски култури, разновидниот добиток, обезбедувале многубројни производи. За тоа биле неопходни разновидни алатки за обработка на земјата и обработката на производите. 
Комбинацијата на богата и вкусна храна и колоритните ракотворби биле презентација на умешноста за домаќинското однесување во фамилиите, особено во моментите на обреди, прослави и празници во македонската култура. Гостопримливоста, музикалноста, динамиката и топлината, целосната слика која што ја дефинира македонската култура, била особено богато видлива токму на прославите.

Главен извор на информации околу македонското културно наследство беше Етнолошкиот музеј во склоп на Музејот на Република Северна Македонија (сл.33. - 42). Меѓу изложените експонати можеа да се препознаат носии од целата територија, многубројни функционални и декоративни предмети од секојдневието и четири реконструкции на дневни соби од различни области.
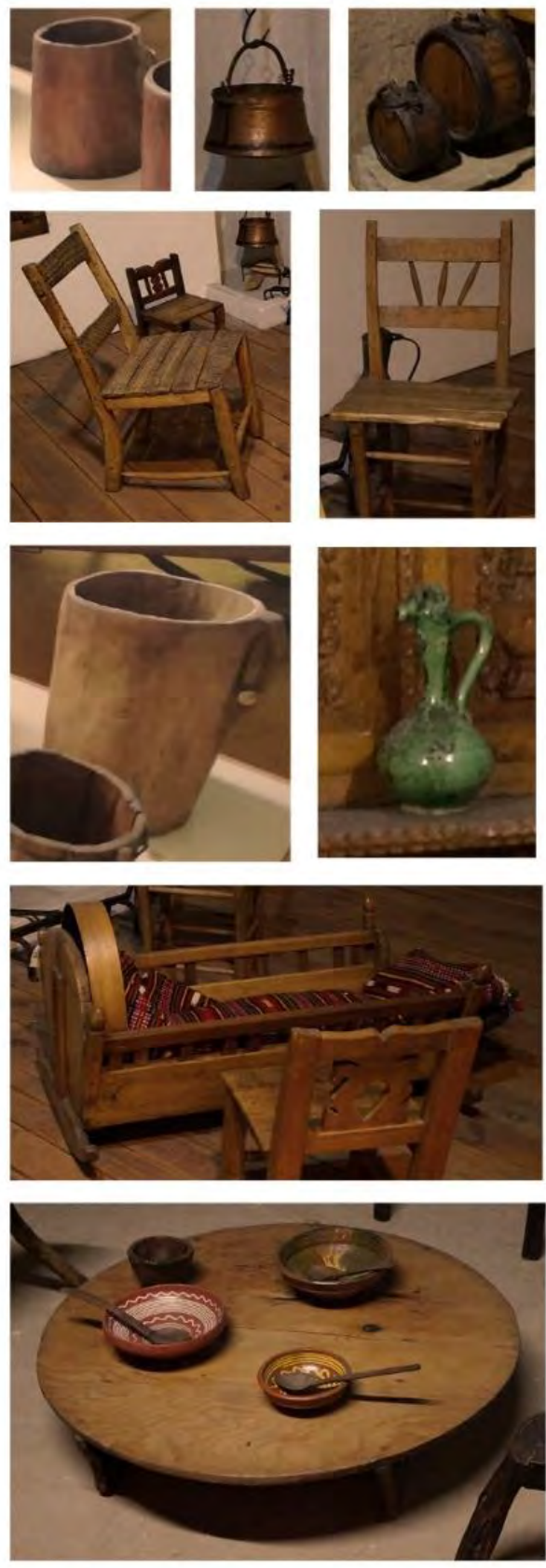

Сл. 32. Избор на традиционални предмети од домаќинствата
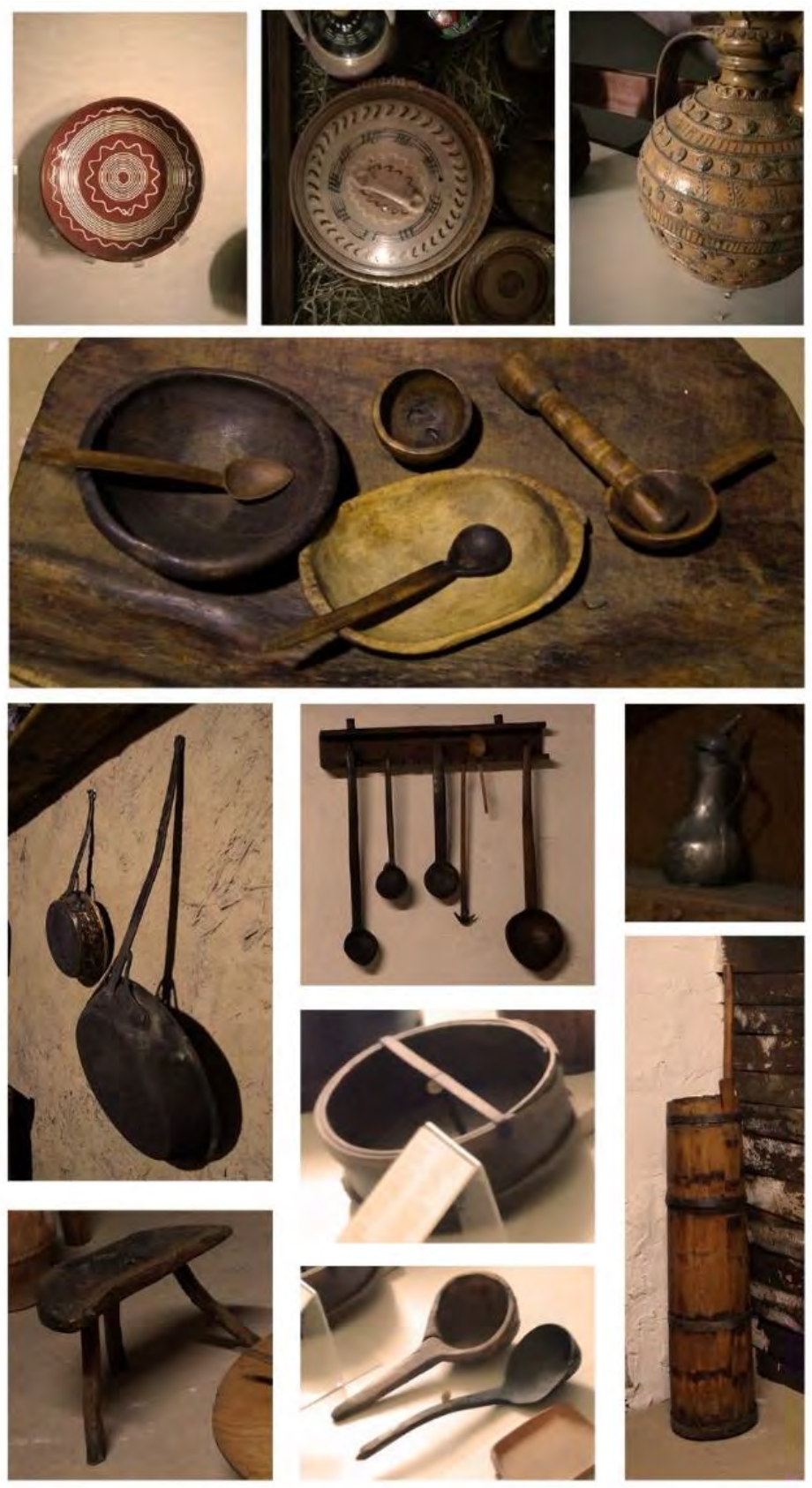


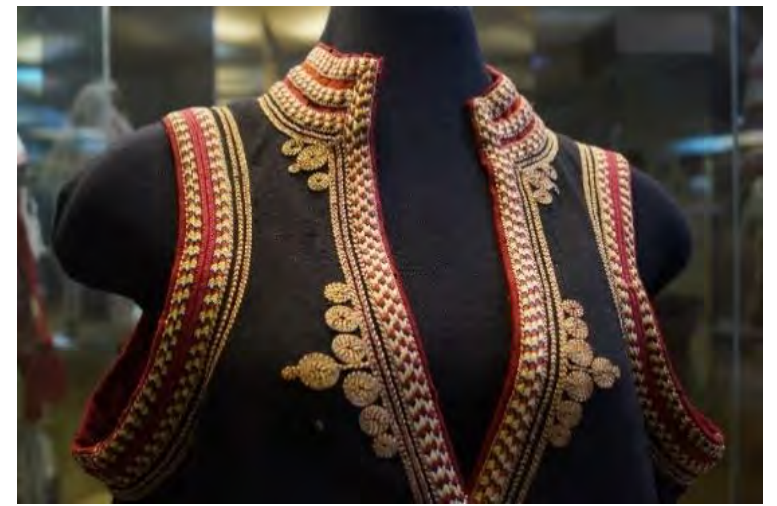

Сл. 33. Богато декориран елек од женска носија

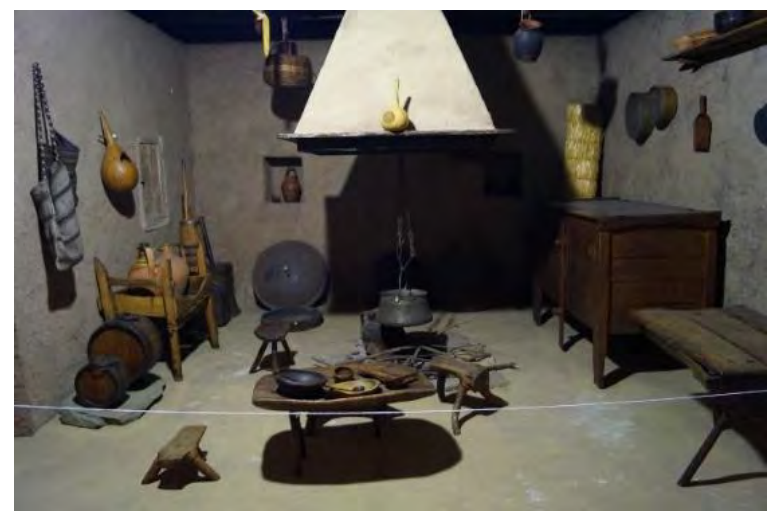

Сл. 35. Реконструиран рурален простор

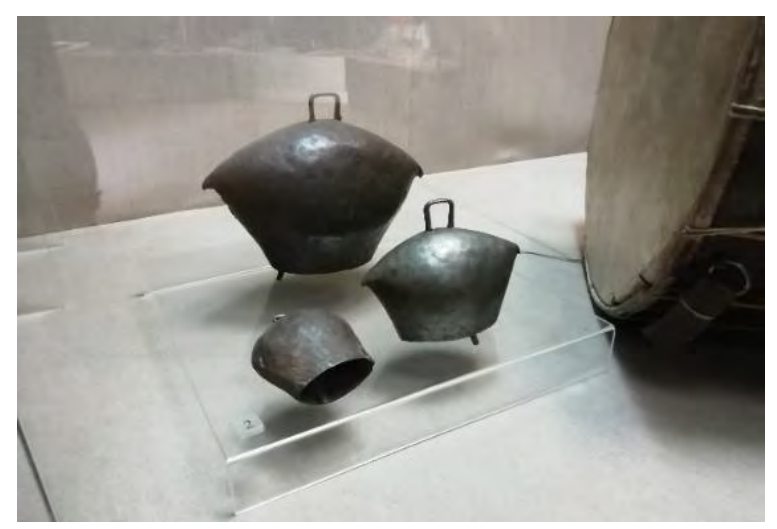

Сл. 37. Бвона за добиток

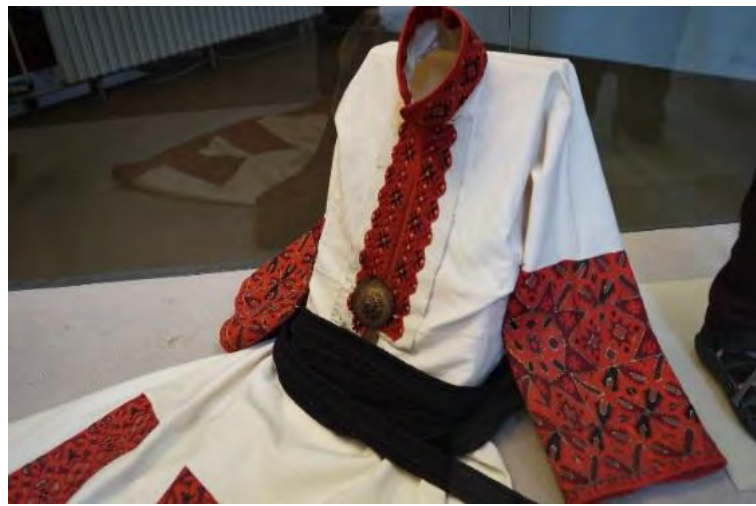

Сл. 34. Кошула од женска носија со богат вез

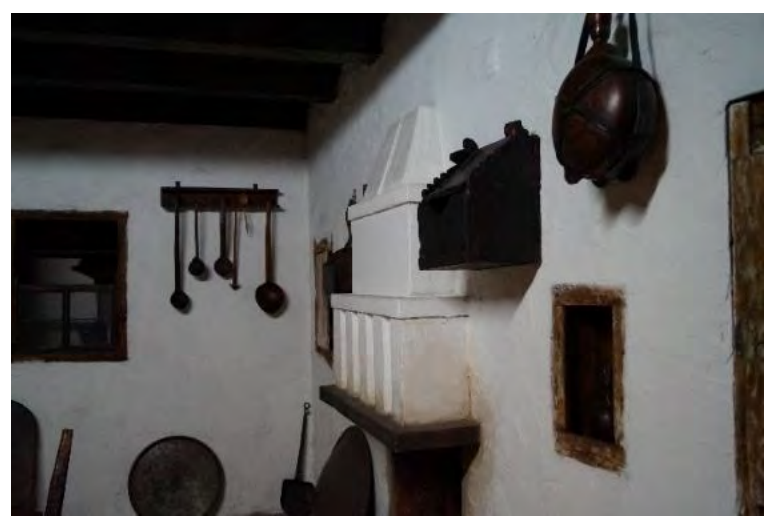

Сл. 36. Детал од ентериер

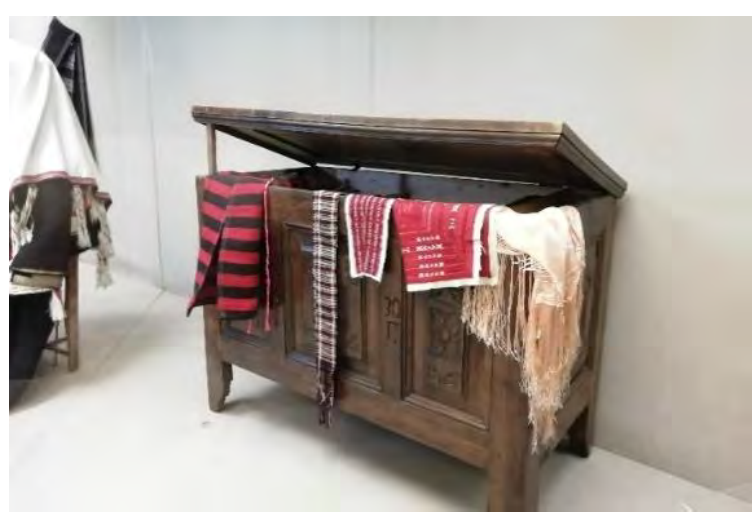

Сл. 38. Сандак 


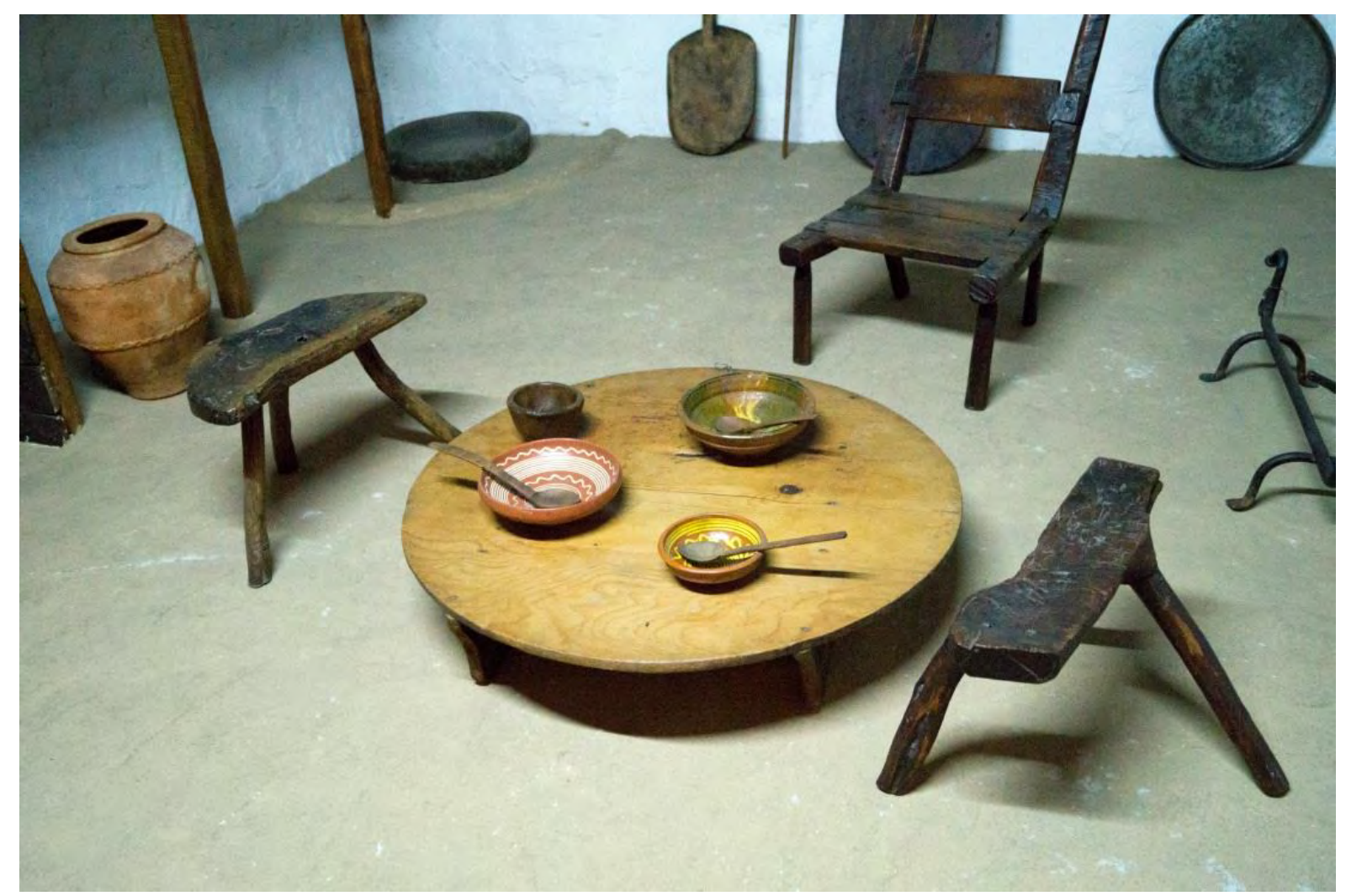

Сл. 39. Реконструиран рурален простор

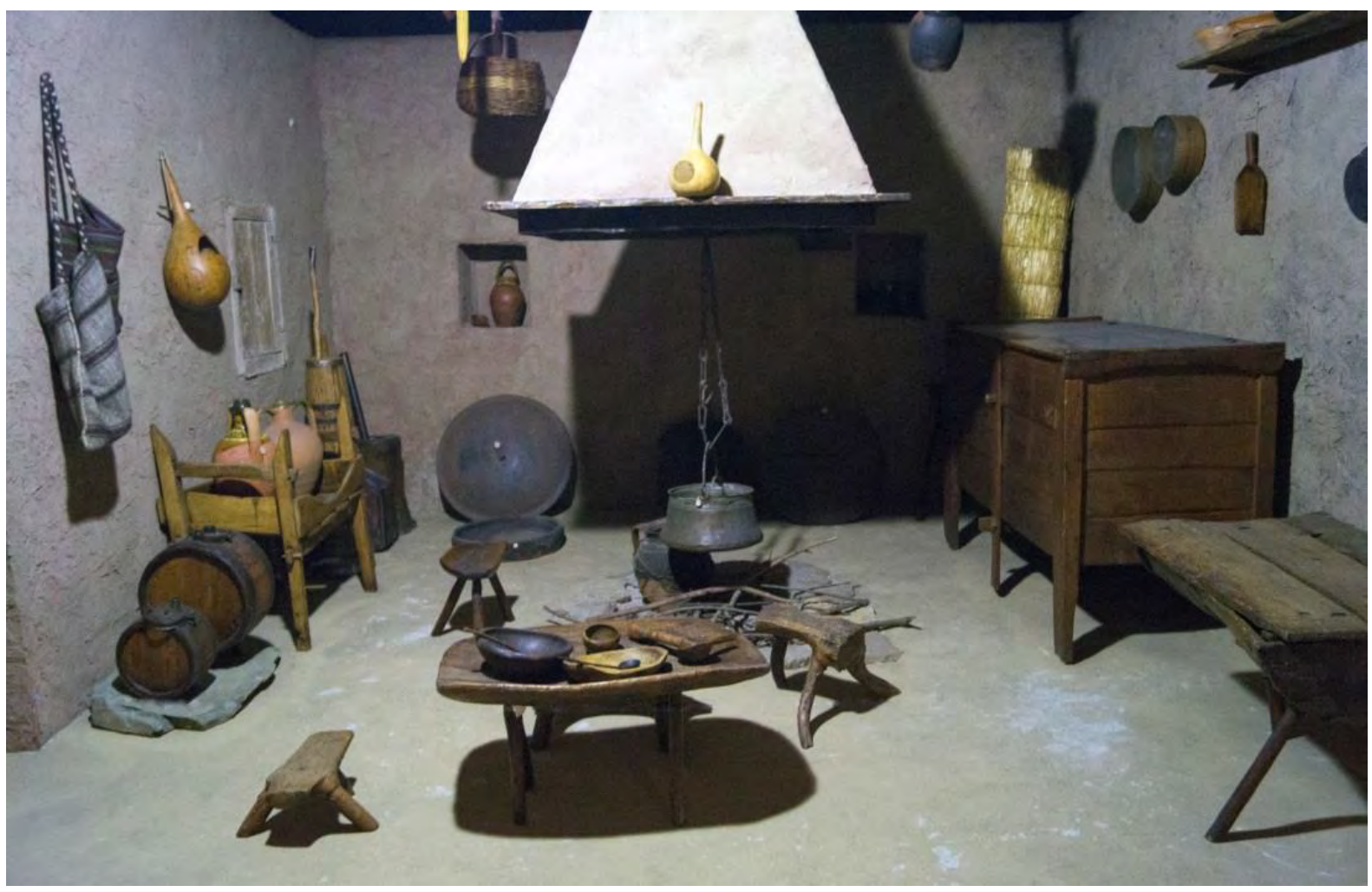

Сл. 40. Реконструиран рурален простор 


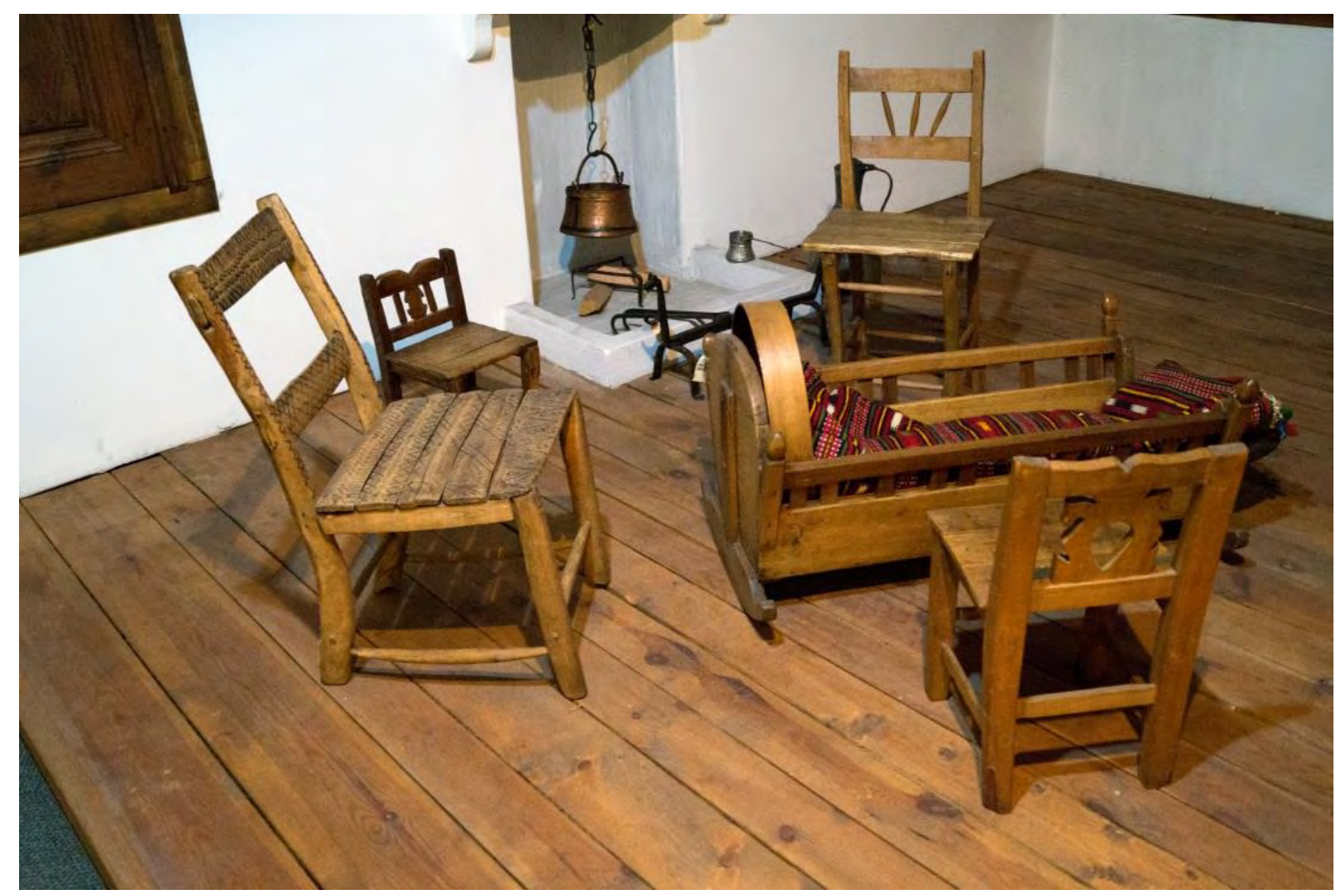

Сл. 41. Дел од ентериер

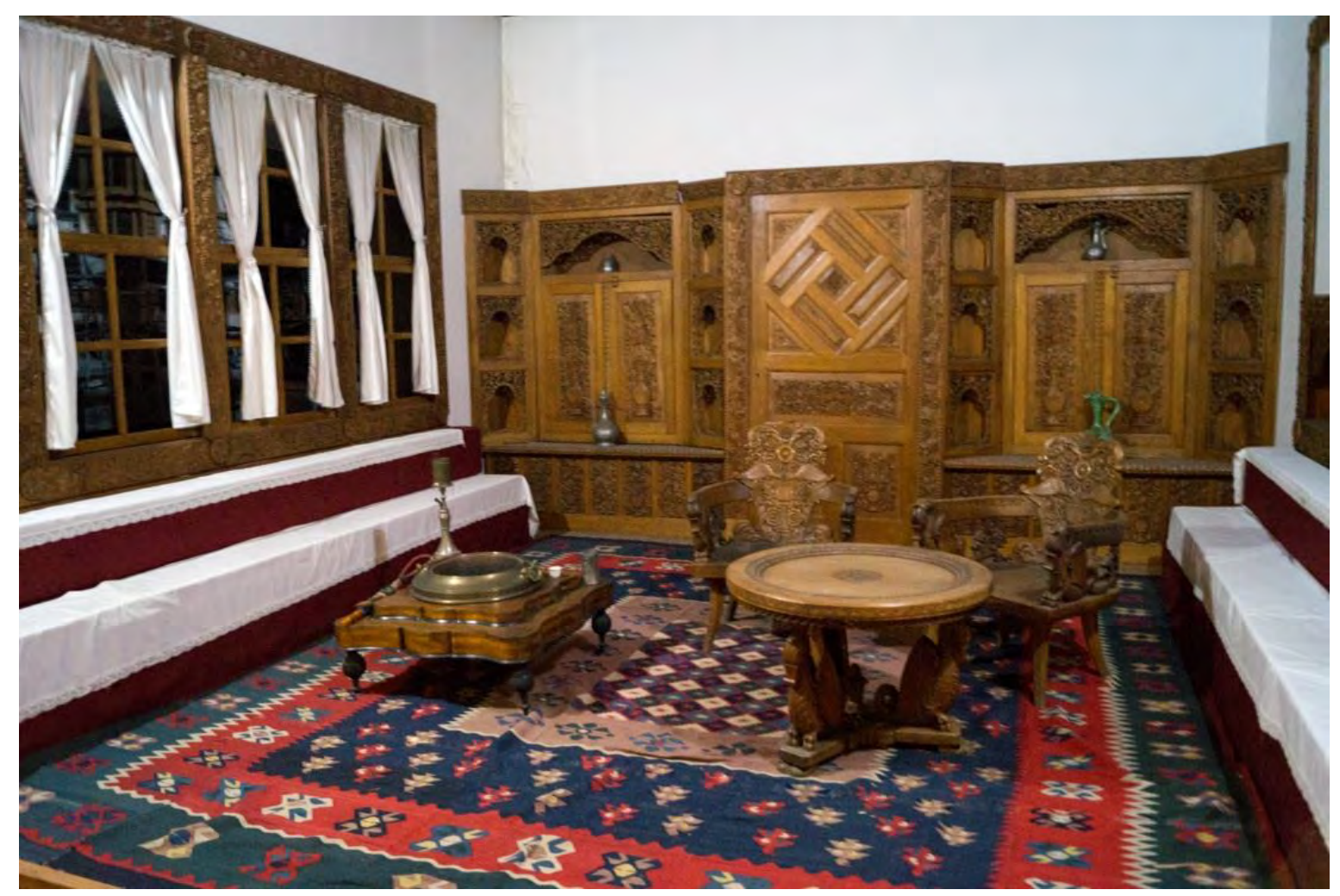

Сл. 42. Реконструкција на градски ентериер 


\subsection{2 Селекција и класифицикација на предмети за анализирање}

Целокупниот собран материјал од првата фаза покажа дека обемот на истражувањето може да биде огромен доколку не се направи селекција на карактеристични примери од повеќе категории производи. Како краен резултат на анализата на сите собрани материјали од првата фаза на истражувањето извршена е класификација на неколку категории производи за понатамошно проучување на нивните визуелни карактеристики:

1. текстилни производи: облека (носии), везени ткаенини и килими;

2. дрвени производи: столарија, мебел, декоративни елементи со дрворез;

3. керамички производи: стомни, бардаци, кујнски садови;

4. метални производи: садови за секојдневниот живот, алати за работа, украсни предмети и накит;

Со оглед на фактот дека бројот на собраните материјали беше голем, беше одлучено да се изберат по неколку карактеристични примери од сите категории кои ги носат вообичаените визуелни карактеристики за нив.

\subsubsection{1 Категорија текстилни производи}

Носии - дизајнот на македонската традиционална носија варира зависно од географскиот регион од кој потекнува (сл. 43. - 51). Географската местоположба со себе повлекува и други фактори кои придонесуваат кон големите варијации меѓу носиите, а тоа се: техниките на изработка, трговијата и блискоста со други народи и заедници, пристапот до материјалите и друго. Но сепак, одредени сличности се забележителни кај сите носии, како што се изразената метална тока на струкот на носијата наречена пафта, орнаментирањето со монети, бои и форми на везените шари. Презезентацијата и воздигнувањето на вредноста на носијата било зависно од обредите за кои биле наменети. Најбогата декорација се забележува кај носиите наменети за свадбите.

И покрај многубројните автори и креатори на носиите, според Кличкова [26], заедничкиот елемент што го содржат сите носии е поврзаноста на носијата со идолите на старите религии. Во моментот кога сѐ уште се носеле носии, биле препознаени преку 70 видови женски носии на територијата на Македонија. Поради тоа што деталите и раскошноста се најмногу застапени кај женската носија, истите се земени предвид за анализирање. Машката носија е обично многу поедноставна.

Визуелните елементи и принципи во декорирањето на носиите ќе бидат разгледани преку примерите на женските носии од Галичник, Штип и Крива Паланка. Причината за ова ограничување е преголемиот диверзитет и распространетост на носиите, при што анализирањето на сите е посебна и многу поопширна тема.

Во дизајнот на носиите се применети голем дел од техниките на изработка и материјалите присутни во традиционалното секојдневие. Свечените носии се богато декорирани со орнаменти во кои се применети локалните познавања и вештини на мајсторите кои ги изработувале. 


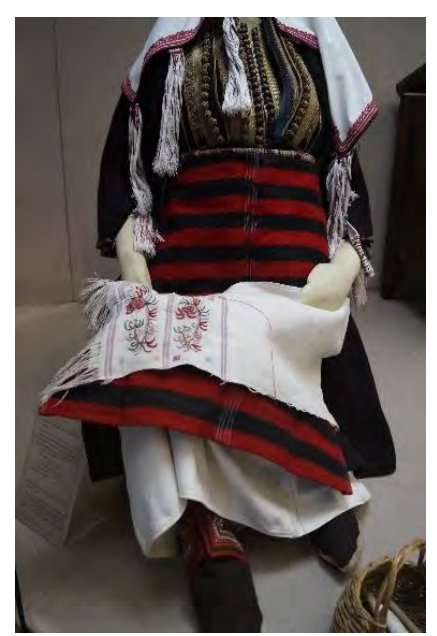

Сл. 43. Скопска носија

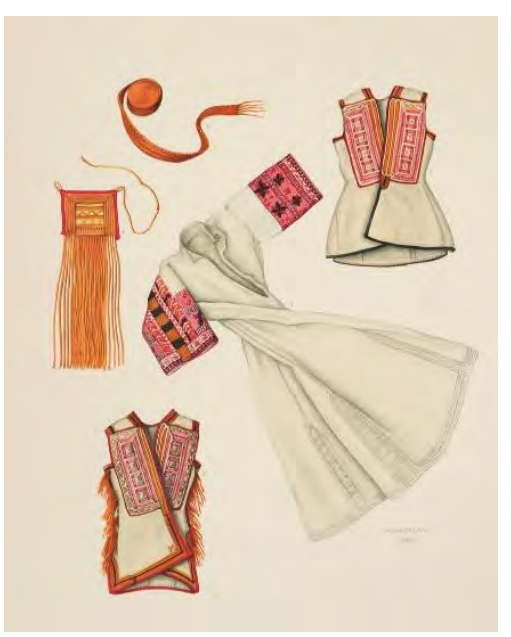

Сл. 46. Илустрација

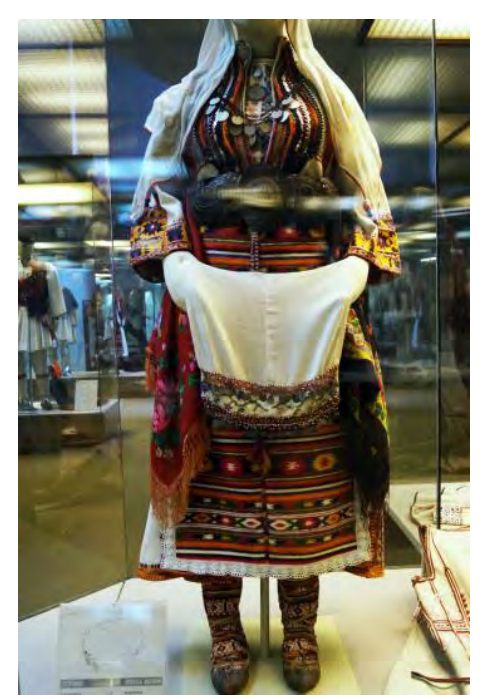

Сл. 49. Носија

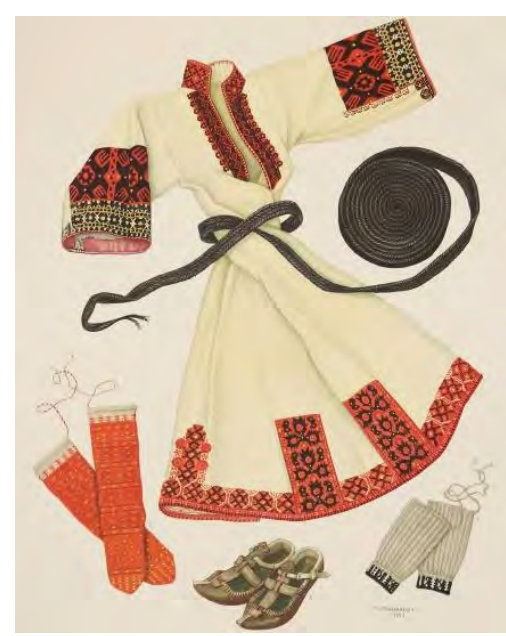

Сл. 44. Илустрација

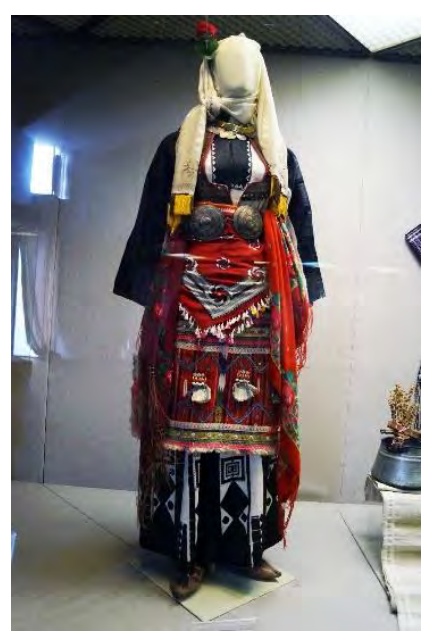

Сл. 47. Hocuja

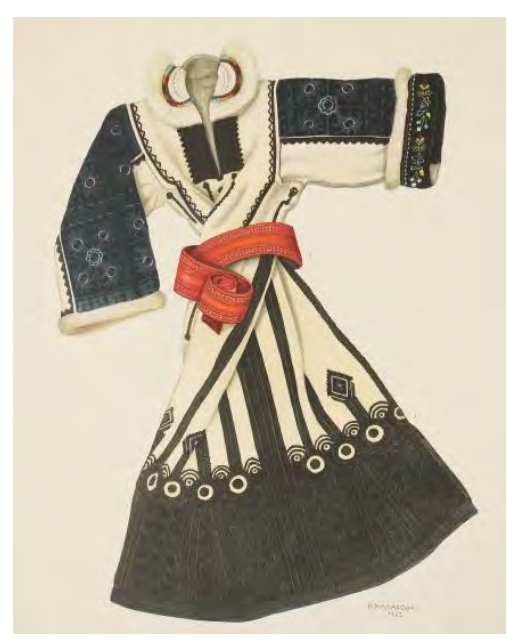

Сл. 50. Илустрација

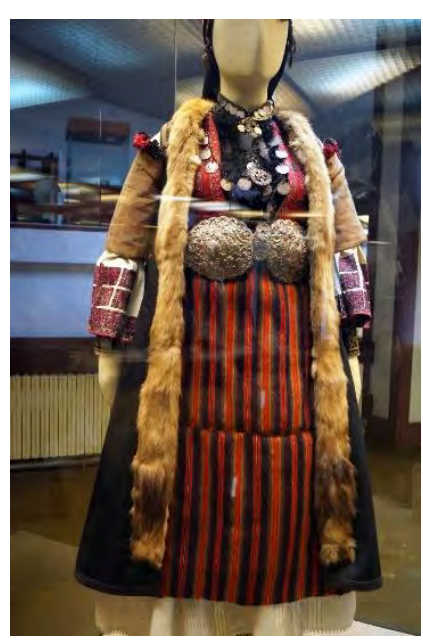

Сл. 45. Hocuja

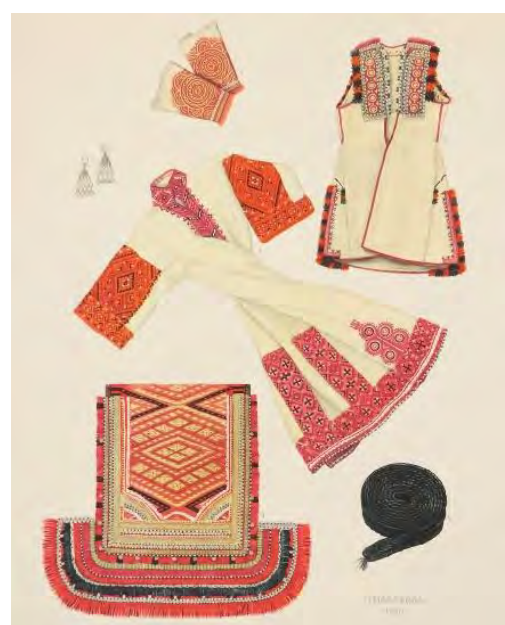

Сл. 48. Илустрација

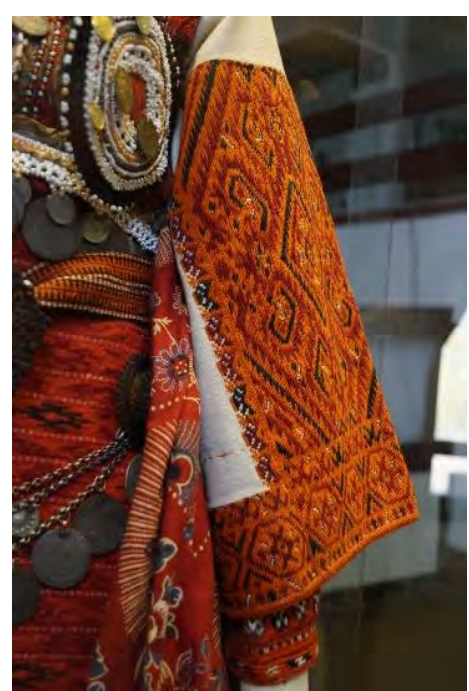

Сл. 51. Hocuja 


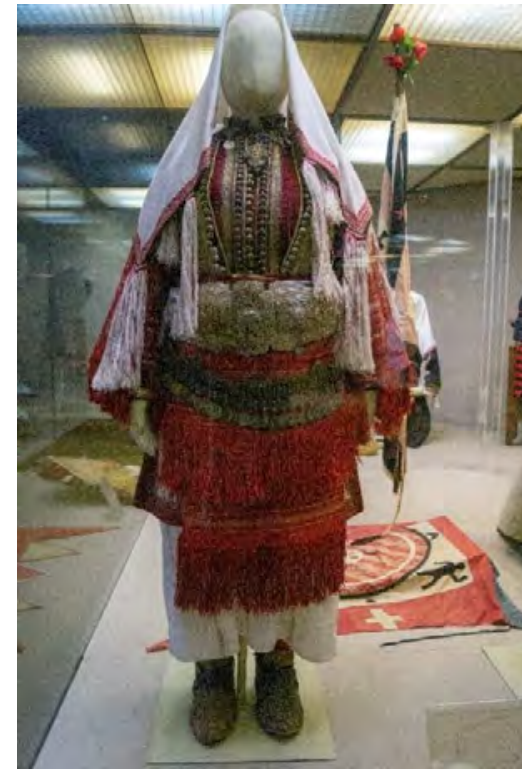

Сл. 52. Галичка носија

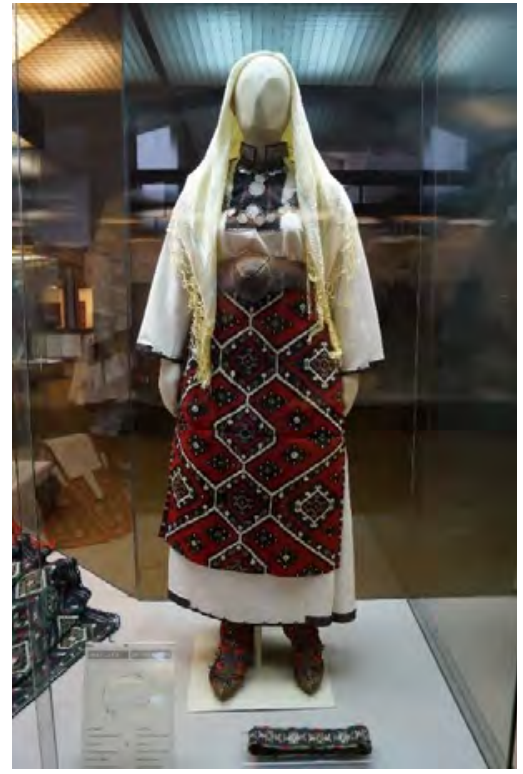

Сл. 53. Кривопаланечка носија

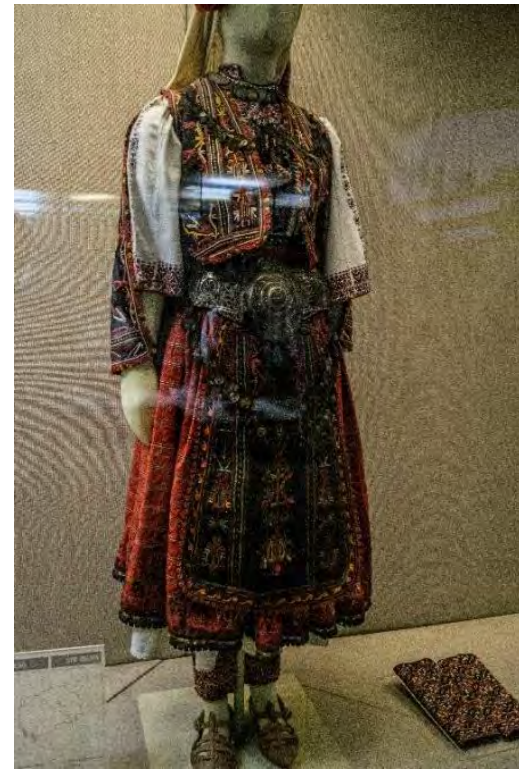

Сл. 54. Штипска носија

Килими - богатите техники на орнаментирање и стилизирање се забележуваат и во други форми на текстилните производи, како што се килимите и везените чаршави, завеси и други декоративни предмети (сл. 55. -63.).

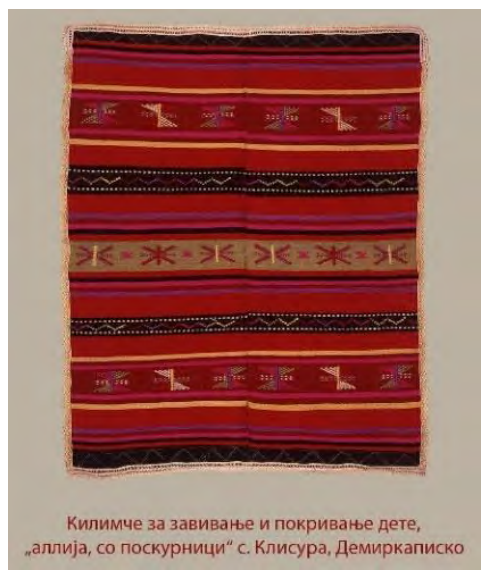

\section{Сл. 55. Килим за завивање}

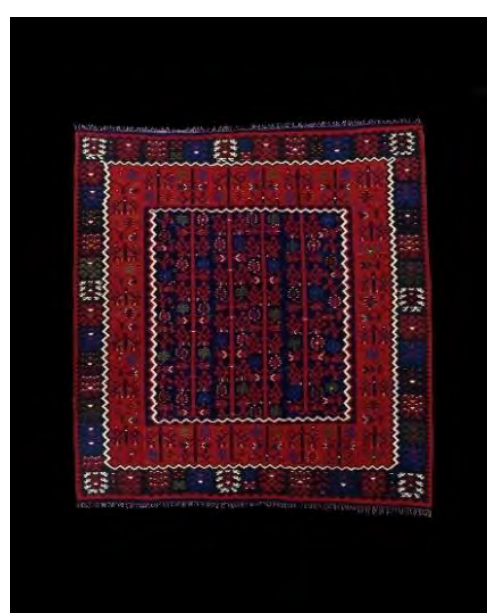

Сл. 58. Пример

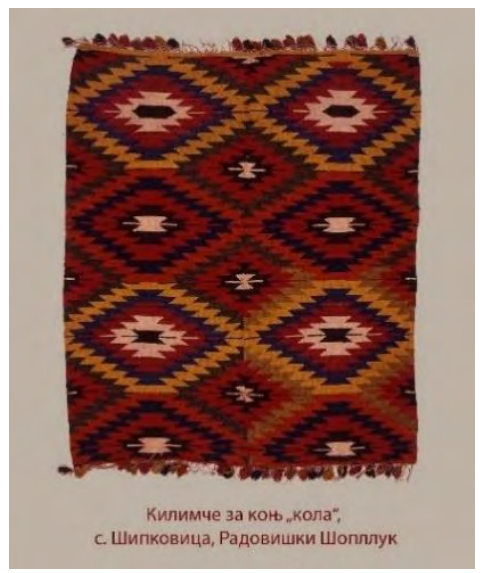

Сл. 56. Килимче за коњ

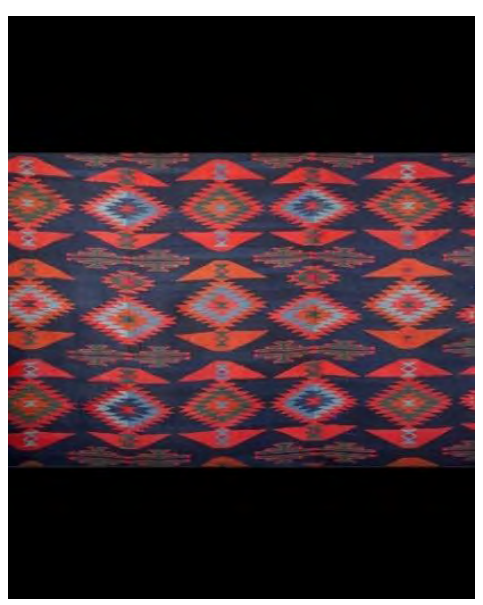

Сл. 59. Пример

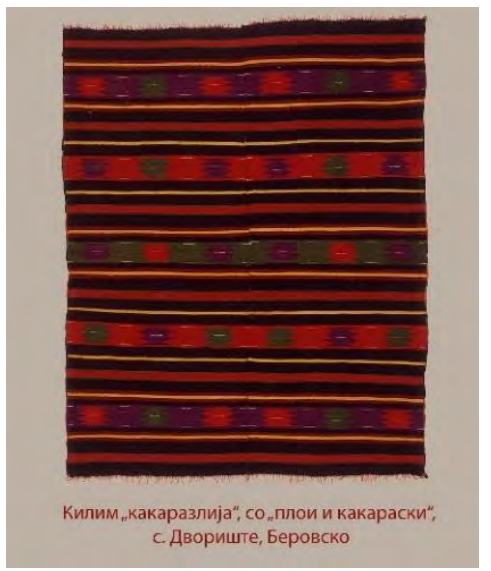

Сл. 57. Килим „какаразлија“

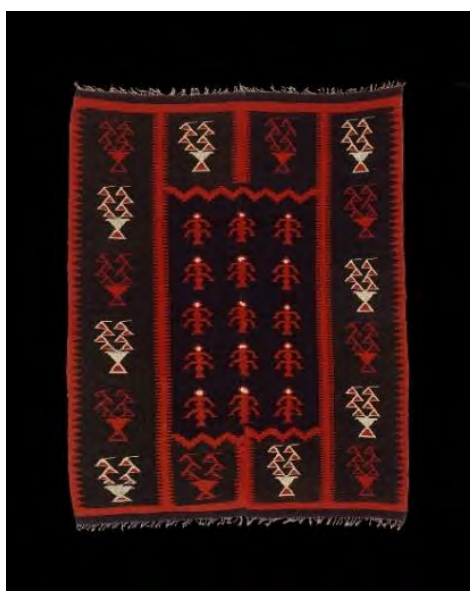

Сл. 60. Пример 


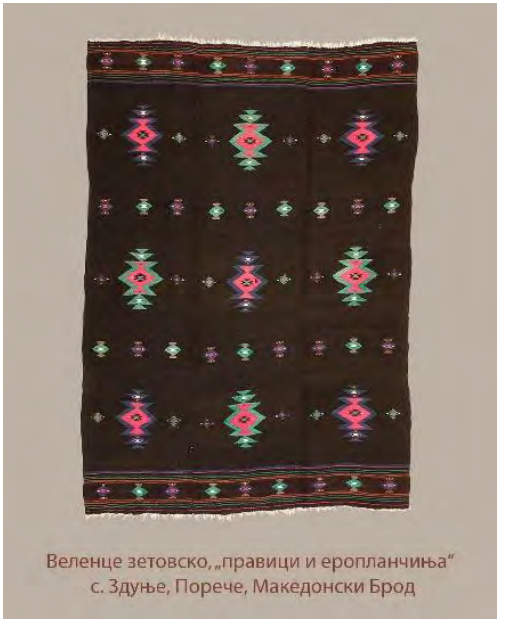

Сл. 61. Веленце зетовско

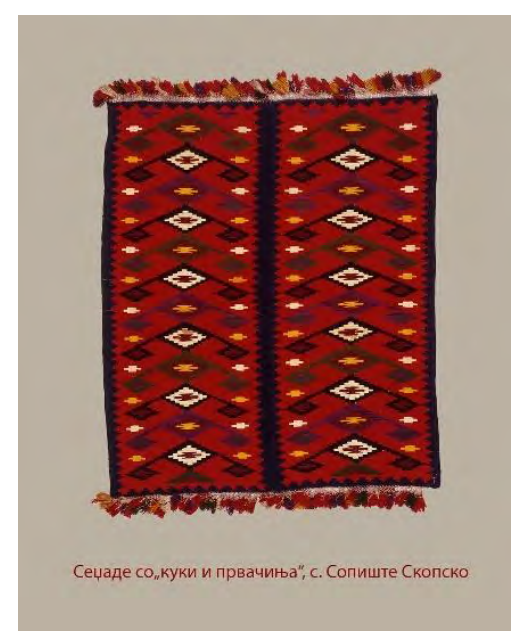

Сл. 62. Сeuade

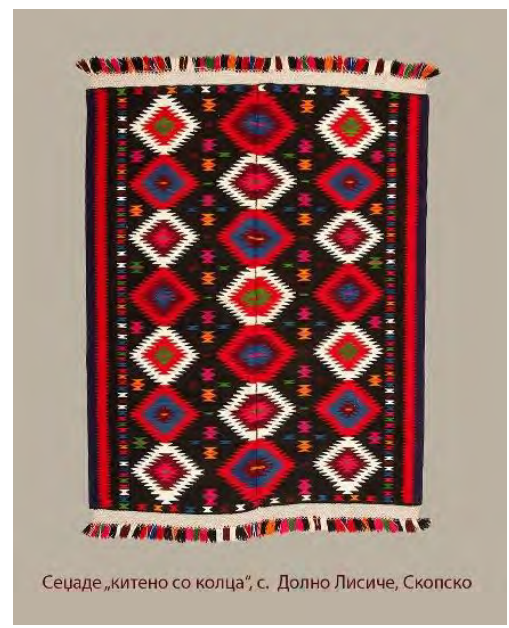

Сл. 63. Сечаde

За понатамошна анализа на визуелните карактеристики се избрани три примери (сл. 64 -66$.$) .$

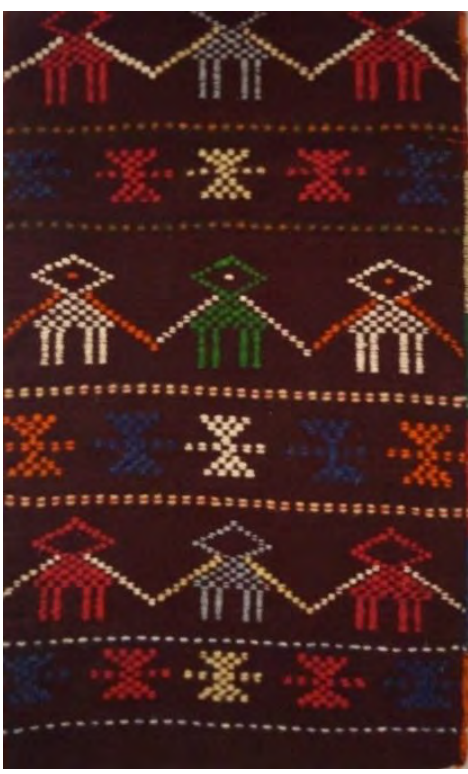

Сл. 64. Избран пример 1

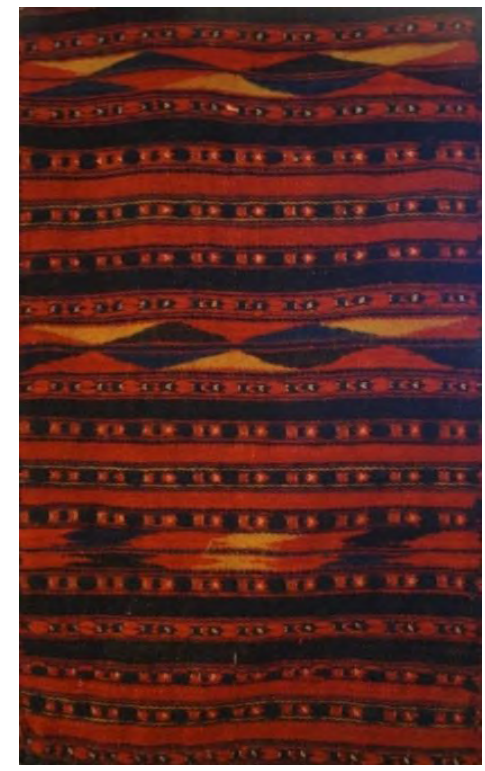

Сл. 65. Избран пример 2

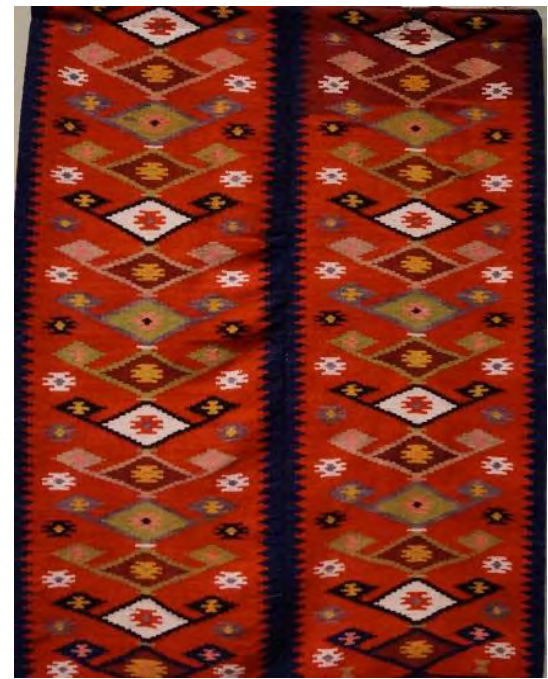

Сл. 66. Избран пример 3

\subsection{2..2 Категорија дрвени производи}

Дрвени предмети - богатото декорирање на домовите асоцира на градски семејства од повисоките и побогатите класи, најчесто трговци и занаетчии. Во руралните средини декорациите не се многу богати и поретко се применувани во споредба со градските, каде што се забележува поголемо богатство детали при изработката на дрвените предмети и декорации, кои честопати се обработени со дрворез и копаничарство. Овој вид производи е разгледуван и од аспект на тридимензионалниот дизајн и од аспект на орнаментацијата. Во рурална средина дрвените предмети имаат доминантно функционална улога (сл.67.- 75). Во тој контекст изработката е скромна и во неа се препознаваат едноставни облици, додека во градскиот контекст, дрвото има подинамична и поорганска композиција. 


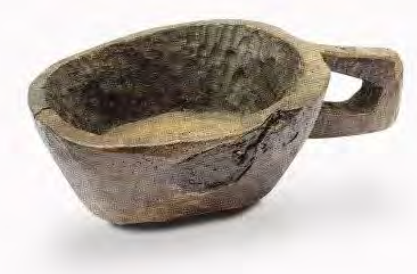

Сл. 67. Шолја

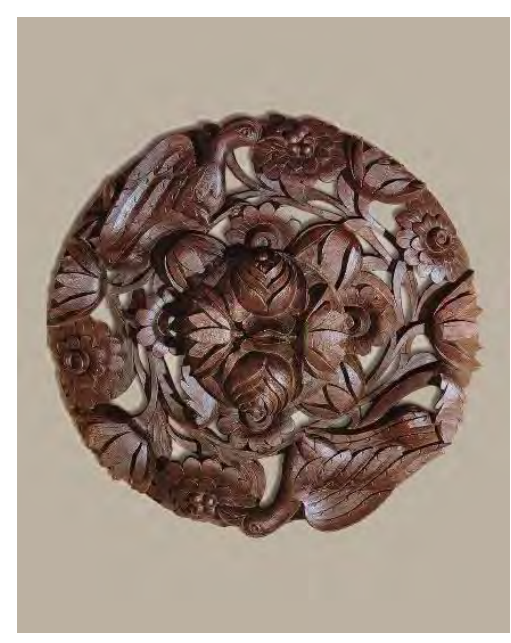

Сл. 70. Резба

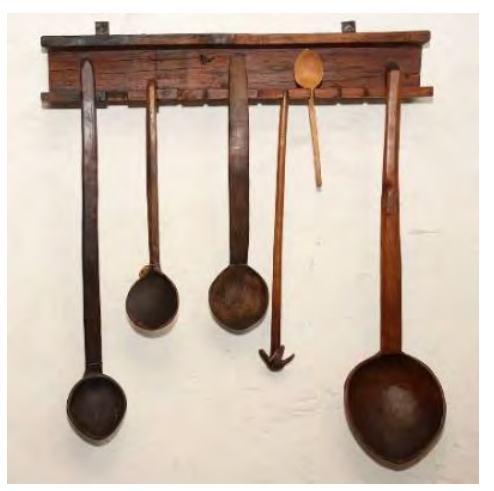

Сл. 73. Лажици

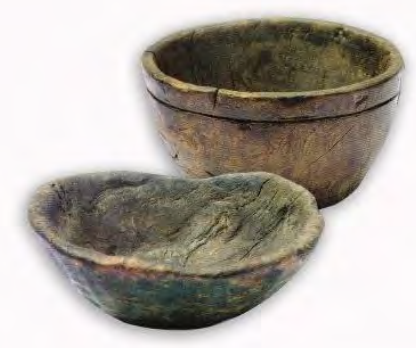

Сл. 68. Дрвени садови

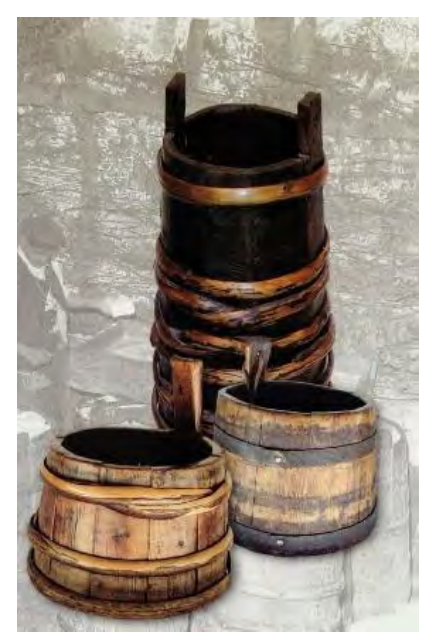

Сл. 71. Кача

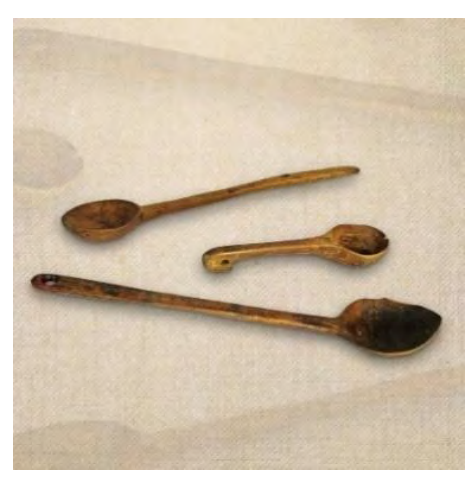

Сл. 74. Лажици

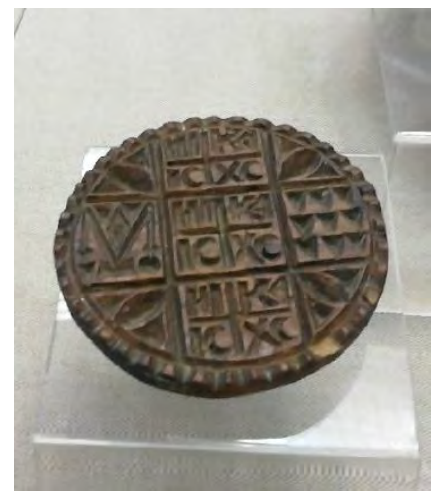

Сл. 69. Печат за леб

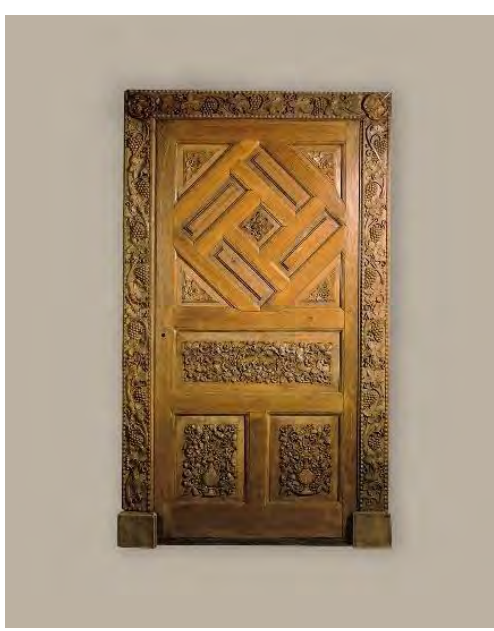

Сл. 72. Врата со резба

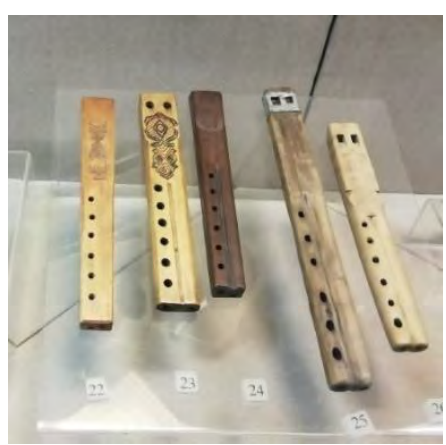

Сл. 75. Кавали

Од практични причини извршен е избор на три дрвени предмети за понатамошна анализа, презентирани на сл. 76. -78 . 


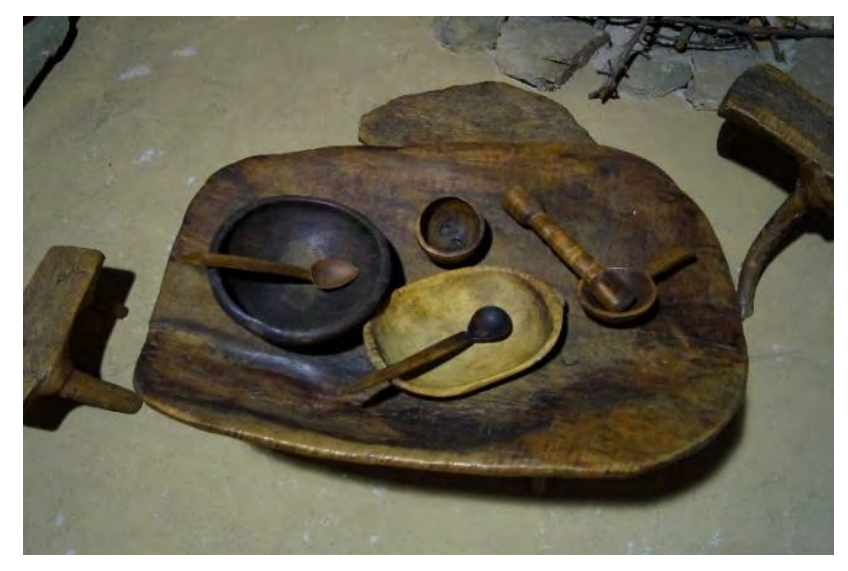

Сл. 76. Трпезариска маса и прибор

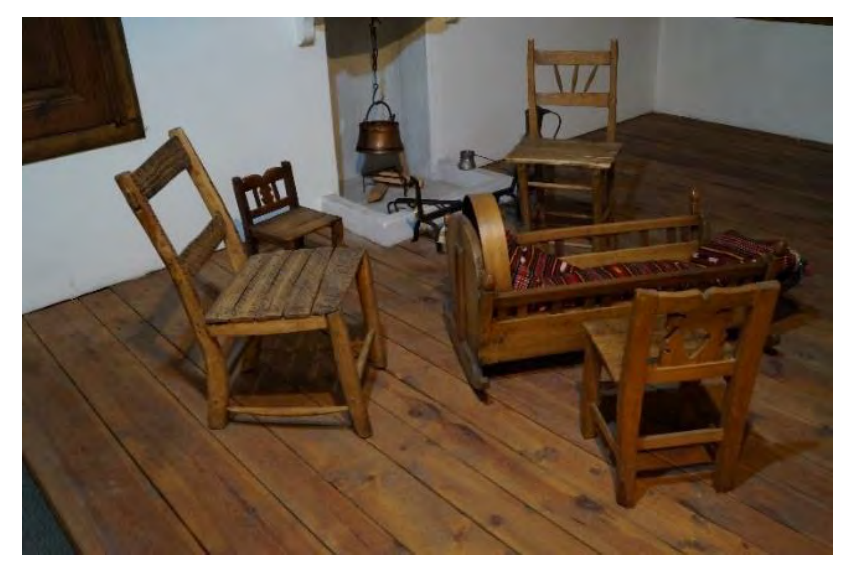

Сл. 77. Столица

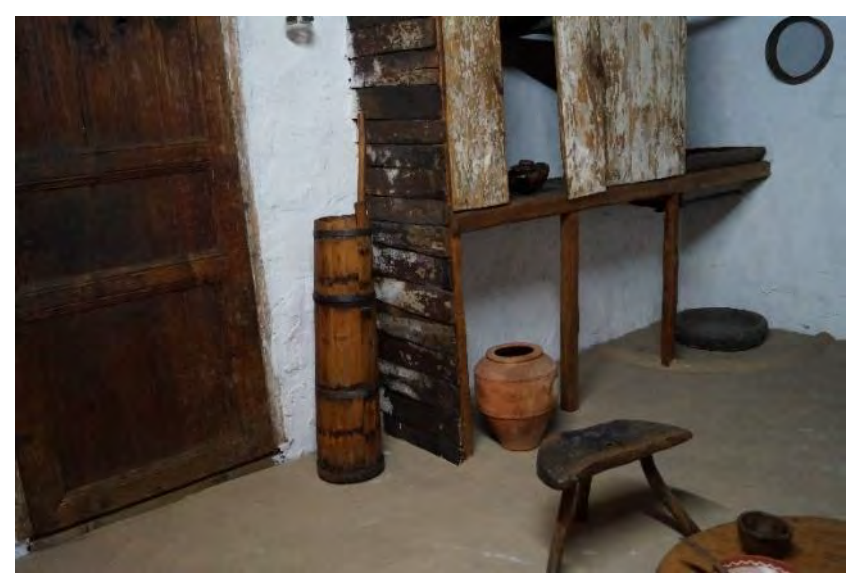

Сл. 78. Бутин за путер

\subsubsection{3 Категорија керамички производи}

Керамички предмети - се работи за разновидни садови од глина кои биле изработувани од едноставна технологија, најчесто со примена на грнчарско тркало (сл.79. - 84.). Се одликуваат со меки заоблени форми и богати декорации со орнаменти. Селектирани се три керамички производи со декоративна и функционална примена во домовите (сл.85. -87.). 


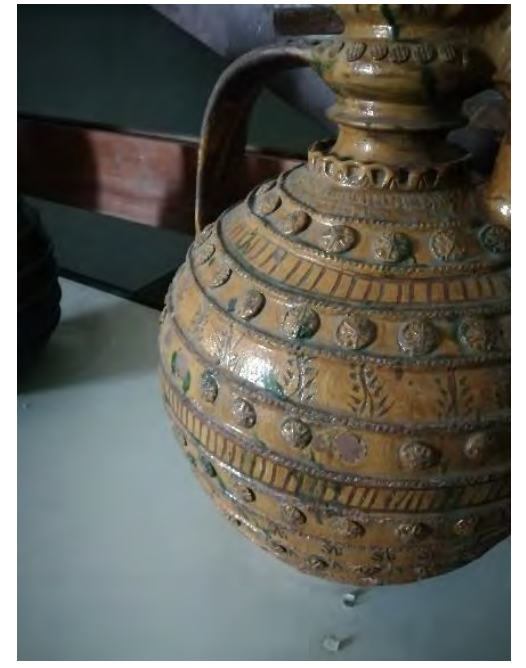

Сл. 79. Стомна за вода

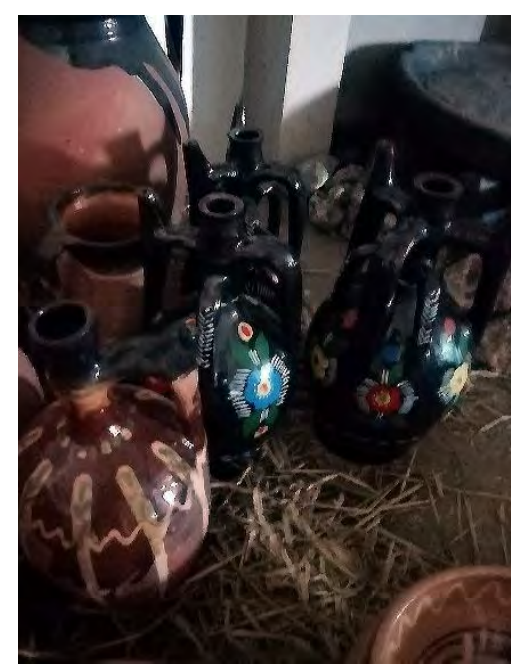

Сл. 82. Стомни за вода

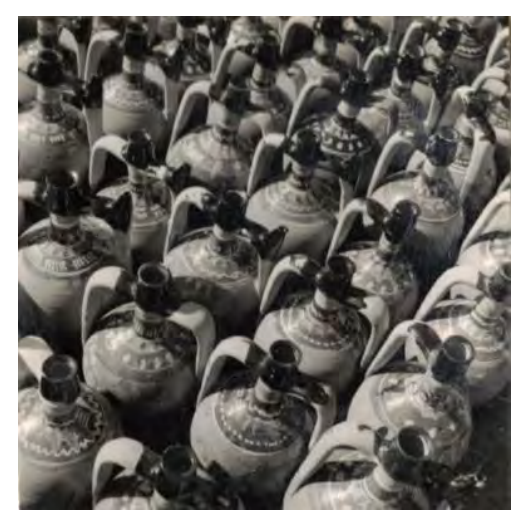

Сл. 80. Стомни

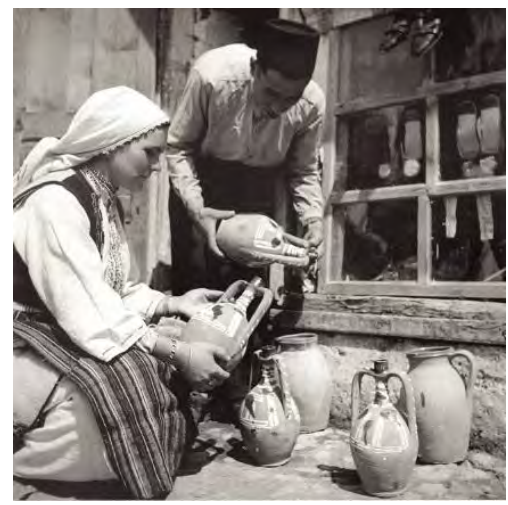

Сл. 83. Стомни за вода

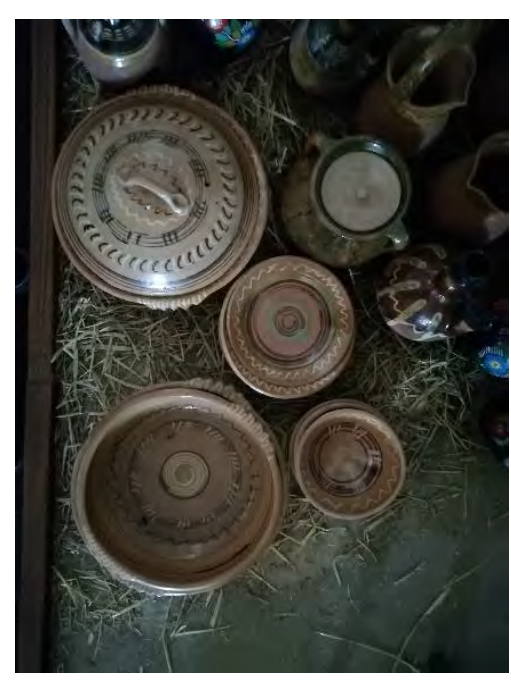

Сл. 81. Грниња

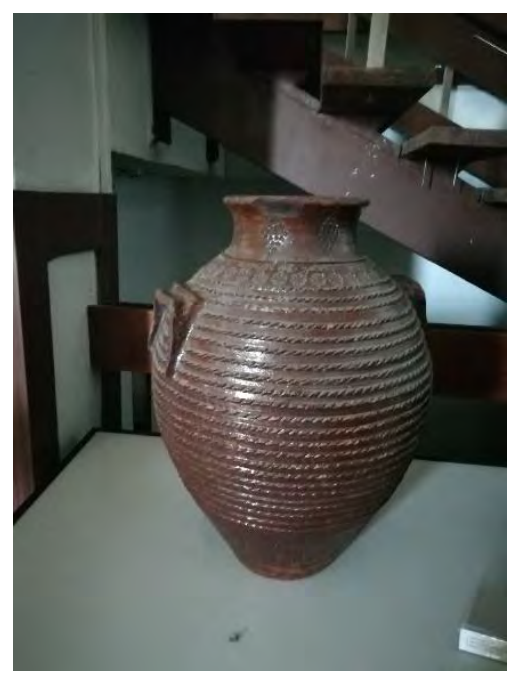

Сл. 84. Стомна за вода

Овој вид производи се интересни за анализирање и од аспект на нивната тридимензионална форма, но и од аспект на применетата орнаментација. Извршен е потесен избор на неколку репрезентативни примери прикажани на сл. 85, 86 и 87.

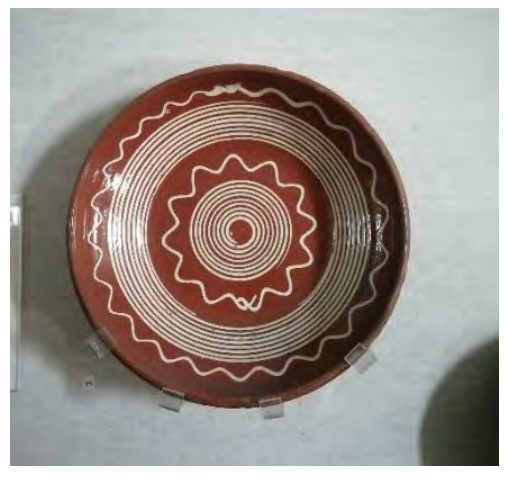

Сл. 85. Плиток сад со еднобојна декорација

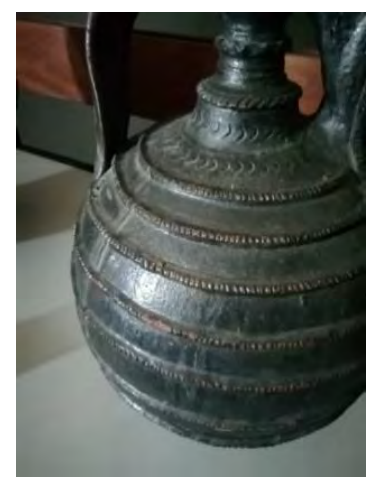

Сл. 86. Стомна за вода со рељефнна декорација

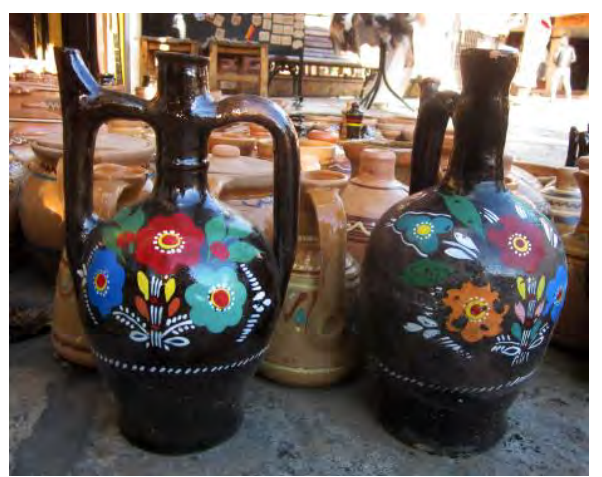

Сл. 87. Стомни за вода со декорација во боја 


\subsubsection{4 Категорија метални производи}

Метални предмети - со појавата на занаетите и формирањето на еснафите, изработката на производи од метал се одвивала во неколку категории: кујунџиски, филигранџиски, ковачки и многу други. Во контекст на ова истражување, каде целта е естетиката на производите, најинтересни примери за анализа се декоративните производи изработени од сребро и бронза. Првиот избран примерок е декоративен сребрен метален огрлица со ковани детали и симболи (сл. 88.) , вториот е калап за кашкавал (сл. 89.), а третиот ќуп со богати флорални орнаменти (сл. 90.). Филигранот во македонската традиција има многу значајно место, но поради неговата важност и специфичност нема да биде разгледуван.

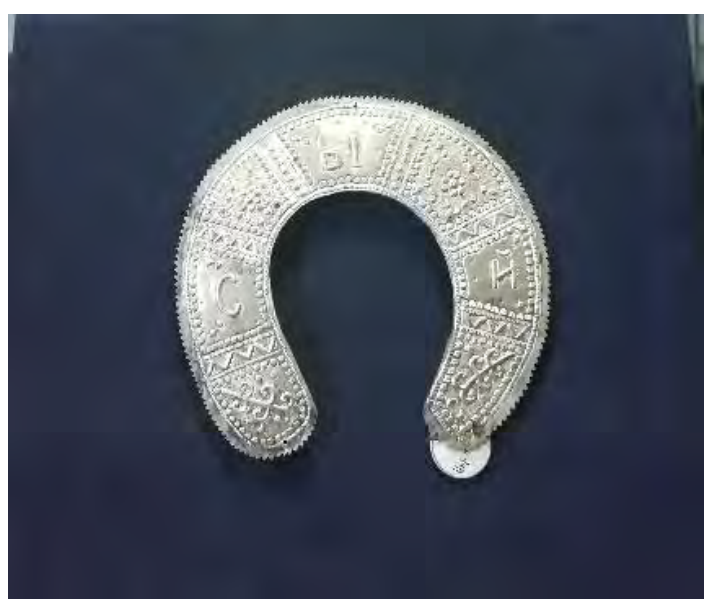

Сл. 88. Метална огрлица

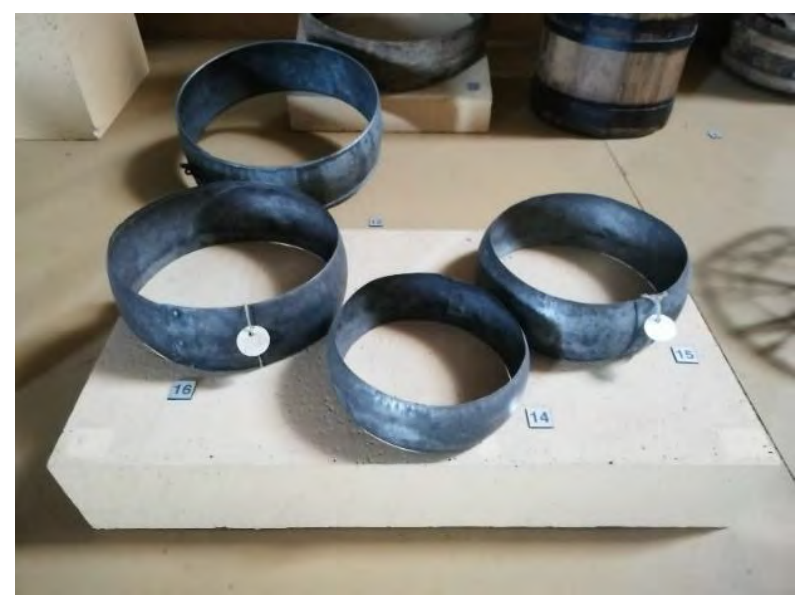

Сл. 89. Калапи за сирење

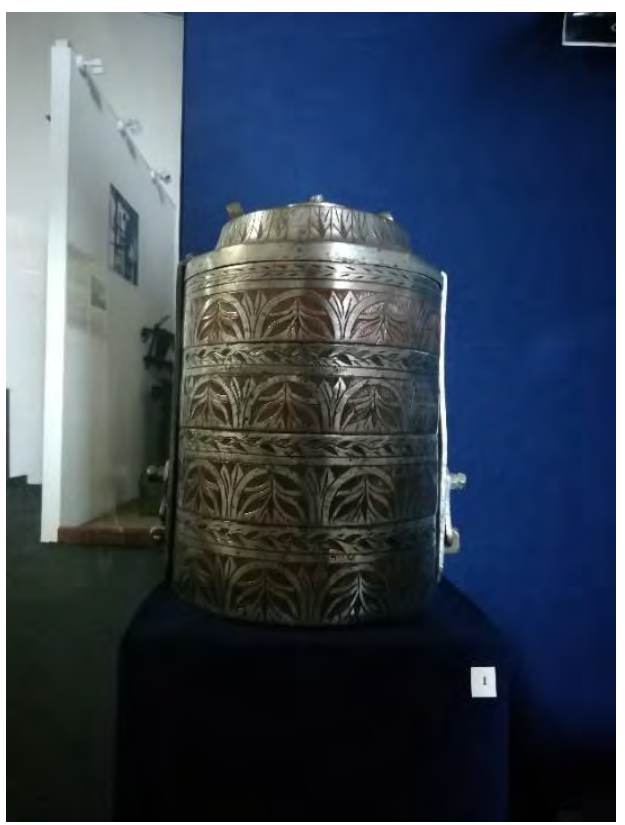

Сл. 90. Вазна - ќуп 


\section{2 Анализа и проучување на применетите дизајн елементи и принципи}

\subsection{1 Анализа на елементите}

\subsubsection{1 Линија}

Линијата во текстилните производи може да се анализира од два аспекта: линија како шара, добиена со везот или ткаењето на конецот и линија како контура на формите. Поради технологијата на ткаење и везење, микро-линијата е дефинирана од конците и зависи од поставеноста при ткаењето. Макро-линиите се препознаваат како контури на форми на носиите и на орнаментите.

Во везовите доминираат долги хоризонтални или вертикални линии, со варијации на дебелините и боите, но се среќаваат и назабени, коси и дијагонални. Честопати линиите формираат контури на стилизирани фигури инспирирани од природата (сл. 91 а-г). Генерално се строги геометриски линии, поретко меки, органски.
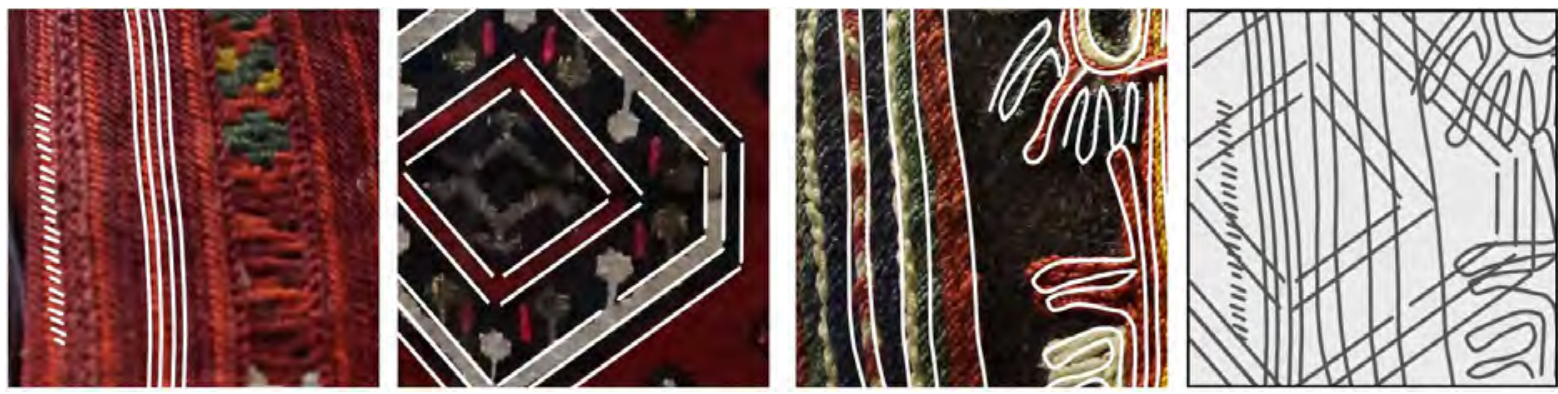

Сл. 91. а, б, в, г Линии кај носиите

Разликите кај линиите меѓу текстилните производи се јавуваат главно поради технологијата на изработка (сл. 92 а-г). Почесто на килимите се забележуваат изразените испрекинати линии кои се паралелни со главните хоризонтални линии. Поради самата природа на ткаењето, косите линии имаат назабен изглед. Може да се забележат и цик-цак линии кои опишуваат одредени форми како начин да се долови коса и дијагонална линија.
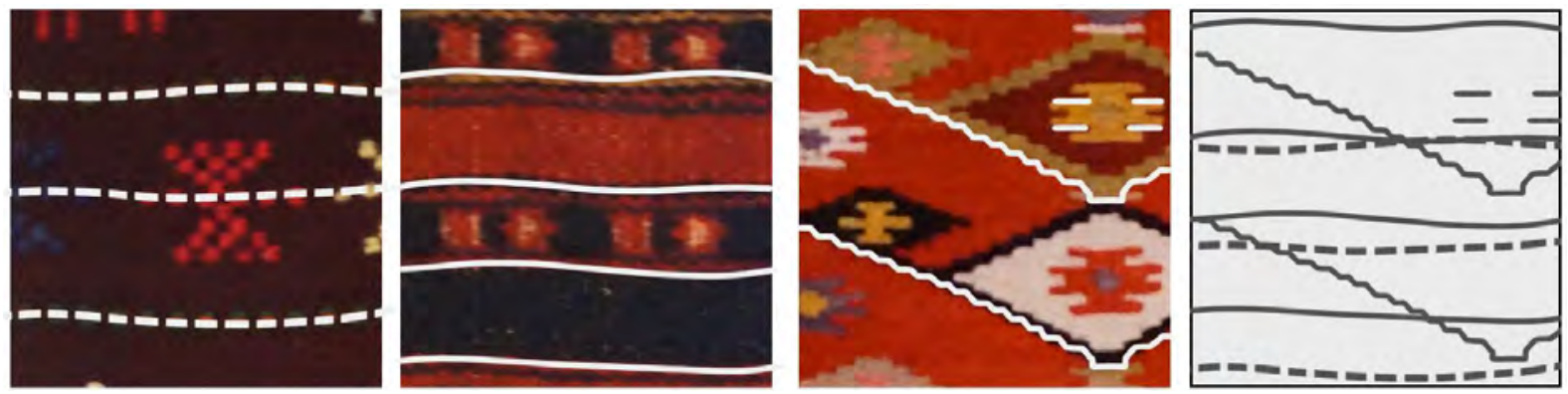

Сл. 92. а, б, в, г Линии кај килимите

Кај грнчарските садови може да се анализираат линиите на шарите и линиите кои ја формираат контурата на формата (сл. 93 а-г). Шарите се најчесто концентрични или спирални кружници или криви линии концентрично поставени во однос на една централна точка. Во третиот случај (сл. 93 в), линиите опишуваат поедноставени шари инспирирани од природата. 
Контурните линии на садовите ја следат насоката на ротација при нивното моделирање (сл. 93. а-в). Во вториот пример се гледаат испакнати линии поради рељефната обработка на површината на садот. Во третиот пример (сл. 93 в), држачите на бокалот ја формираат линијата на целиот предмет.
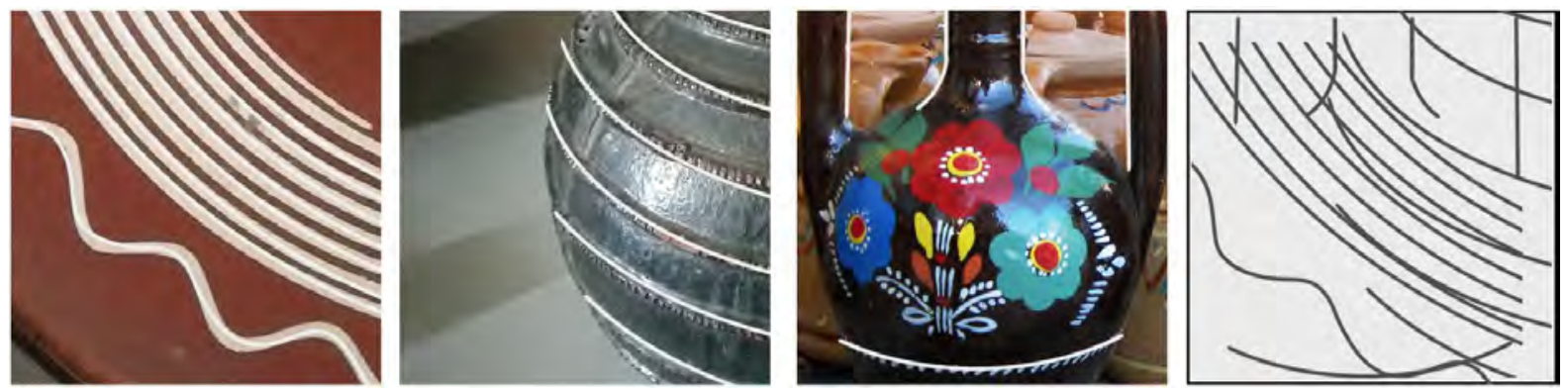

Сл. 93. а, б, в, г Линии кај грнчарските предмети

Линиите на шарите и линиите кои ја формираат контурата на формата се препознаваат и кај примерите на металните производи. Првите два примера имаат контурни линии кои ја следат формата на предметот и линии на шари кои го исполнуваат просторот меѓу или во рамките на контурните линии. Во првиот пример (сл. 94. а), шарите се креирани со комбинации на меки органски и строги геометриски линии, додека на вториот со органски отворени и затворени (сл. 94 б). На последниот пример доминантни се само контурните линии (сл. 94 в).
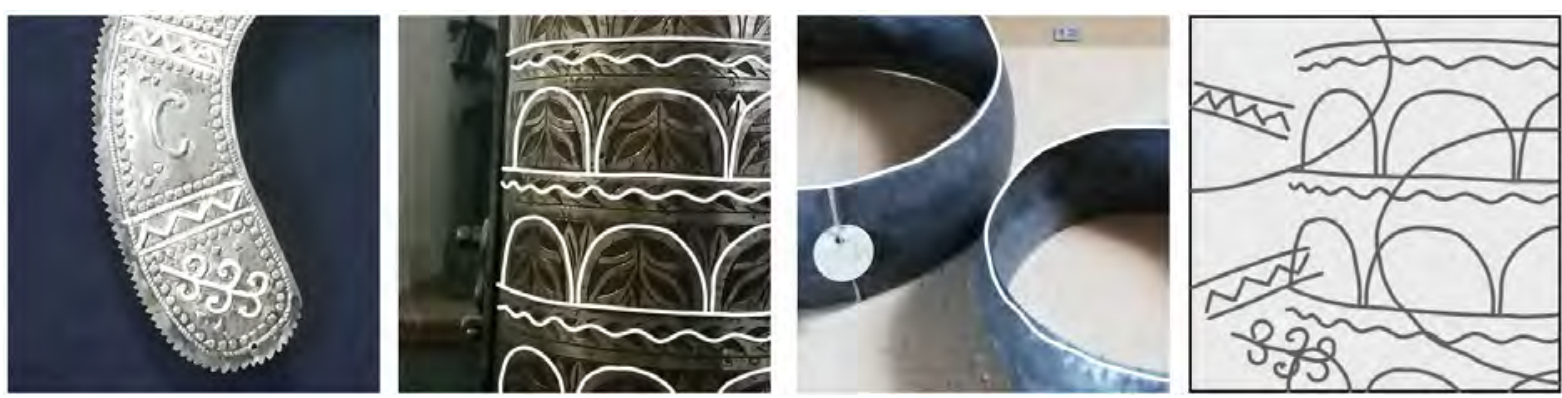

Сл. 94. а, б, в, г Линии кај металните предмети

Дрвените предмети може да бидат изработени на два начина: со вдлабнување од едно цело парче дрво или преку изработување профили и поврзување на истите. Едноставно, дрвените производи може да се изработени од еден дел или од неколку делови и поврзани со метални спојки. Во првиот пример се претставени парчиња трпезариски прибор изработени од едно парче дрво, кај кои се забележува генерална доминација на слободните органски линии (сл. 95. а-г).

Иако другите два примера се композиција од неколку делови, нивните индивидуални карактеристики се различни. Додека на столицата се забележуваат рамни и криви линии, на бучимот за путер се гледа генерално присуството на строги линии. Предметите со висока занаетчиска или производна улога се посклони на геометриски линии поради нивната фукнција. Линиите на предметите од посекојдневен карактер се подинамични и пооргански (сл. 95 а-г). 

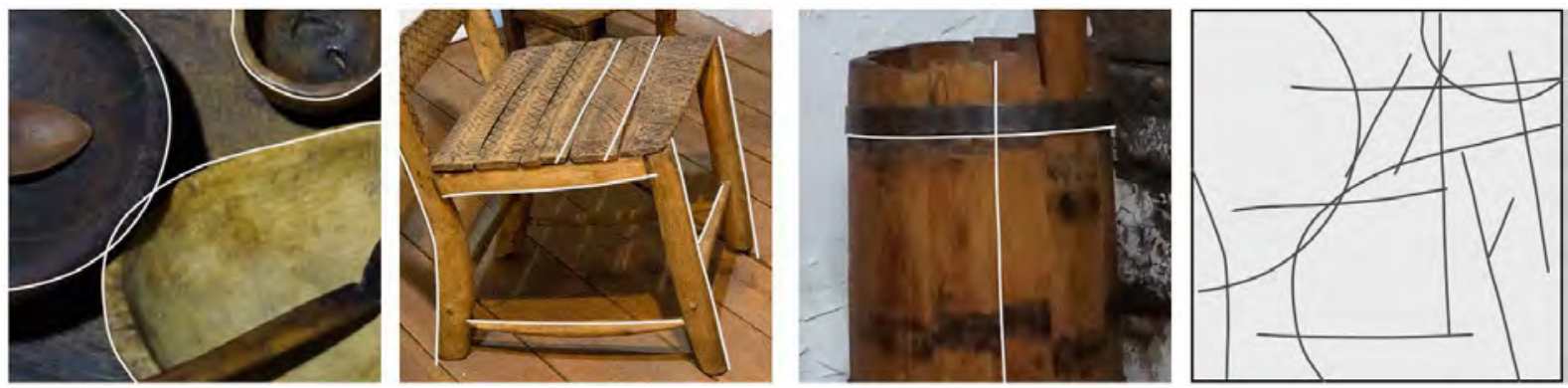

Сл. 95. а, б, в, г Линии кај дрвени предмети

\subsubsection{2 Форма}

Формите кај носиите се всушност применетите шари во везовите (сл. 96 а-г). Кај нив се забележуваат најчесто сложени геометриски форми креирани како симплификација на формите инспирирани од природата (цветови, гранки и слично). Честопати се користат повеќе форми една во друга со што се добиваат побогати форми, оплеменети дополнително со боја. Поретко се применувани органски форми, иако техниката на везење го дозволува и овозможува тоа.
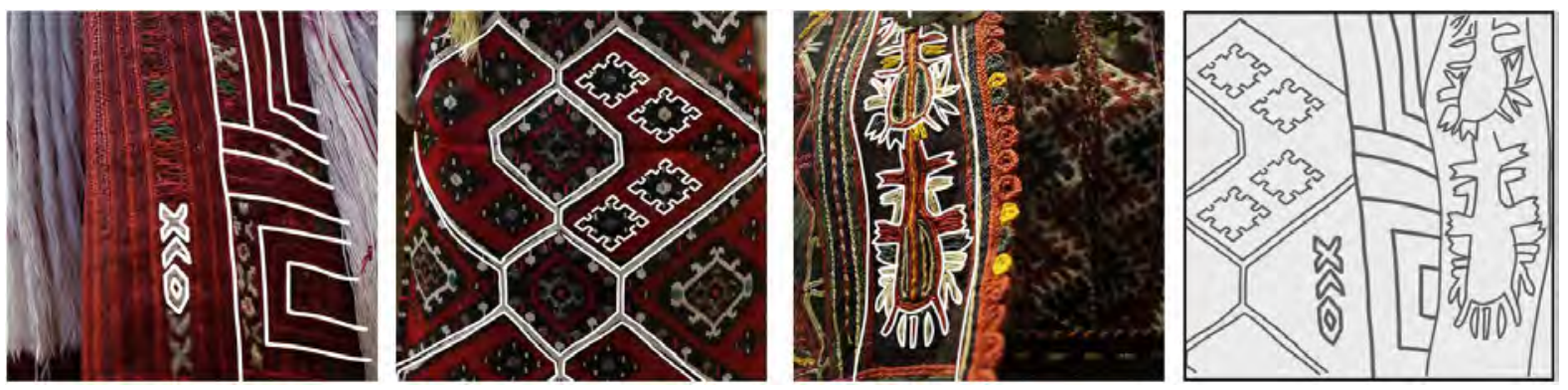

Сл. 96. а, б, в, г Форми кај носиите

Кај ткаените килими очигледна е доминацијата на геометриските форми, особено поради ограничувањата на технологијата на изработка (сл 97. а-г). Формите можат да бидат чисто геометриски и да се префрлуваат едни врз други или може да наликуваат на симплифицирани силуети од урнеци од природата. Во првиот пример се забележува низа на форми кои претставуваат стилизација на контури на луѓе. Во други примери се забележуваат и силуети на животни и растенија. Во третиот пример се забележуваат неколку карактеристични форми различни по сложеност. Доколку се разгледуваат подетално доминантните форми, може да се забележи дека тргнуваат од една геометриска ромбоидна форма и со примена на неколку различни големини се креирани посложени и подинамични форми.
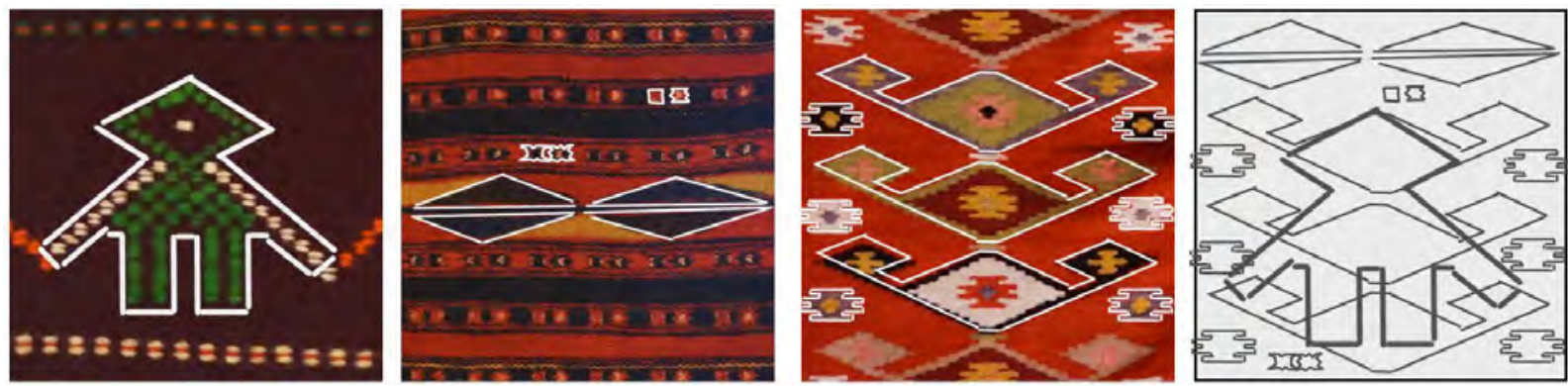

Сл. 97. а, б, в, г Форми кај килимите 
Кај керамичките садови формата е доминатно ротациона, независно дали станува збор за плитки или длабоки садови. Ова е поврзано со технологијата на изработка на овие садови. Поради тоа што садовите се изработуваат со издолжување на глината врз ротационен диск, може да се дискутира за линијата на профилот што ротира, како покарактеристична, напроти формата на финалниот производ (сл. 98. а-г). Но, тука се држачите како форми сами за себе, кои ја збогатуваат основната форма и ја прават покомплексна. Тие овозможуваат симетрија на формата по една или две оски, како што може да се забележи од примерите.
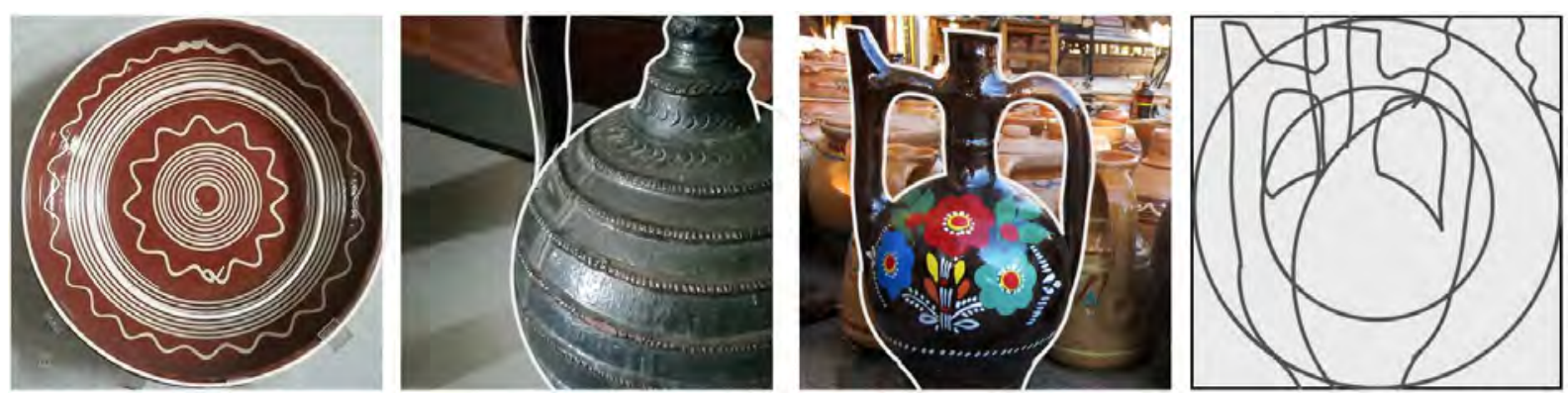

Сл. 98. а, б, в, г Форми кај грнчарските предмети

Презентираните предмети се ектремните случаи меѓу садовите, поточно плиток наспроти длабок сад. Формите на садовите се неверојатно динамични и не следат конкретни правила освен креативноста на авторот. На Сл. 99. се презентирани примери на кои може да се препознаат карактеристичните профили (контури) на формите на грнчарските садови, со или без држачи.

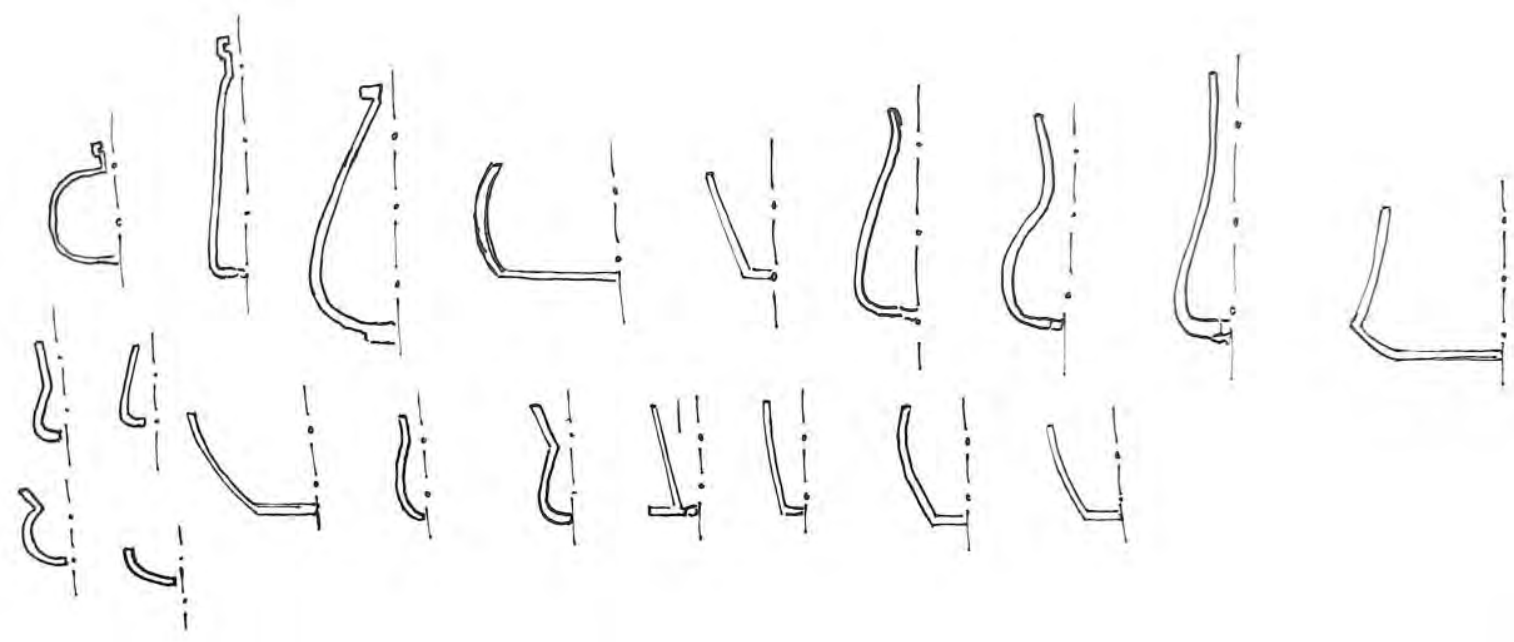

Сл. 99. Профили на садови

Избраните метални предмети се интересни за проучување и од аспект на површинските шари како форми, и од аспект на формата на целиот производ (сл. 100 а-г). Површинските шари се изгравирани во површината на металните производи и зависат од технологијата на изработка. Овие шари се анализирани од аспект на примена на линијата, за која е заклучено дека се присутни и како строги геометриски, и како меки органски. Нивната поврзаност во затворени или отворени низи овозможува креирање форми (шари) кои претставуваат симплификација на форми од природата. Формите на металните производи како целина се во тесна врска со нивната функција. Технологијата на обработка на металите дозволила и сложени форми, претежно заоблени. 

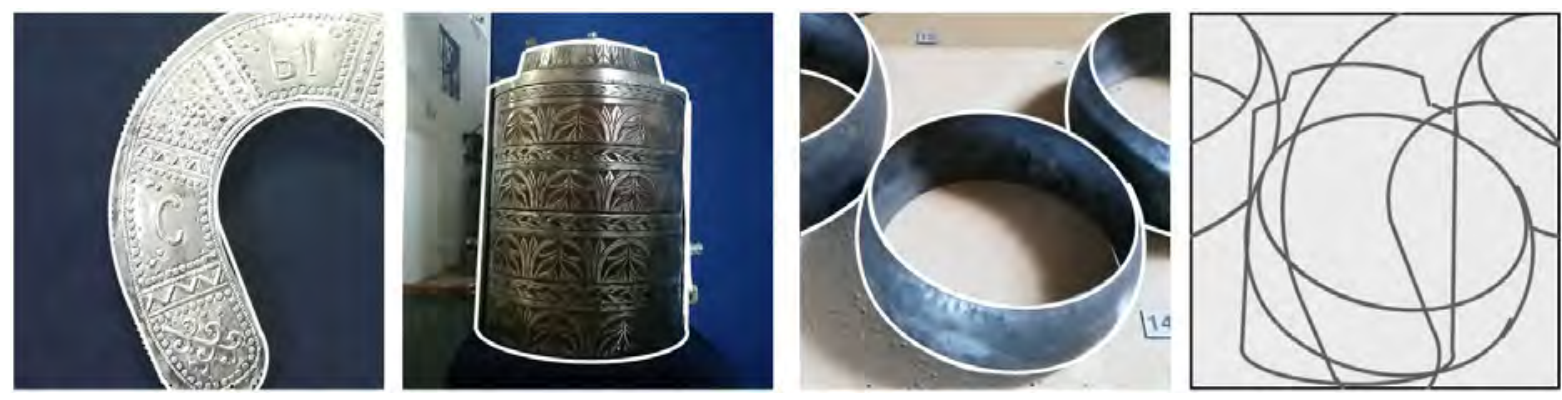

Сл. 100. а, б, в, г Форми кај метални предмети

Имајќи ја предвид технологијата на изработка на производи од дрво, нивните форми можат бидат разгледувани како надворешни форми и форми на декоративни орнаменти. Многу карактеристични за македонската традиција се примерите на длабока или плитка резба, со кои биле украсувани богатите домови, а особено иконостасите на црквите. Но, таа тема е многу значајна и комплексна како целина, поради што може да биде предмет на засебно истражување.
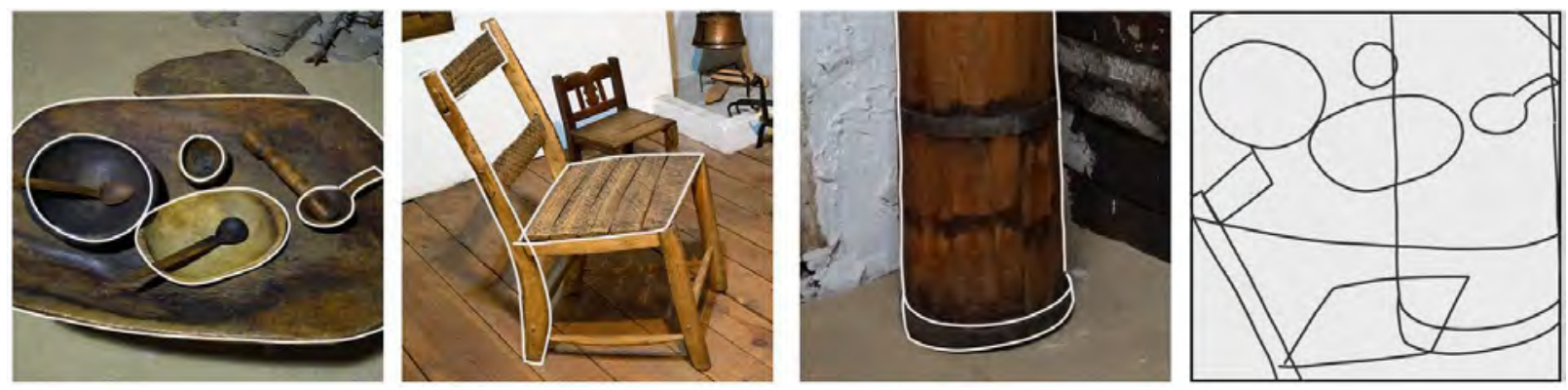

Сл. 101. a, б, в, г Форми кај дрвени предмети

Формите кај првиот презентиран пример, трпезариската маса и садовите, се неправилни, органски и доста едноставни (сл. 101a). Кај столицата формите се комбинација од призматични, цилиндрични и форми кои преминуваат од призматични во закривени (сл. 1016). Кај бучимот се забележува цилиндрична форма (сл. 101в). Организирањето на индивидуалните компоненти води кон создавањето посложени форми. Делумно преработените делови имаат пооргански слободни форми со мали ограничувања зависно од нивното ниво на функционалност. Поголем дел од предметите се со едноставна минималистичка естетика, поради нивната форма која има основна цел - задоволување на функцијата за која се наменети.

\subsubsection{3 Боја}

Примената на боите во македонската традиција е најзабележителна кај текстилните производи, поточно во везовите на носиите и шарите на килимите. Кај носиите најзабележителни се везовите на елеците, скутините и рабовите на ракавите и јаките (сл. 102. а,б,в). Со анализа на избраните три носии беа препознаени најприсутни бои, извлечени и презентирани во палета (сл. 102 г). 

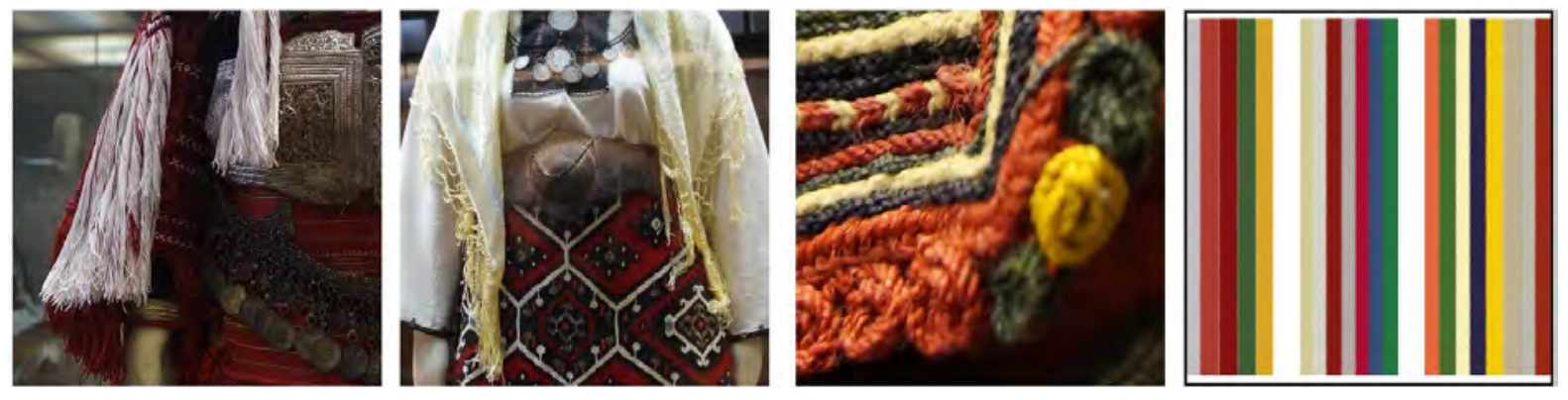

Сл. 102. а, 6, в, г Бои кај носии

Со употреба на софтверот Adobe Photoshop и алатката Eyedropper беа препознаени неколку нијанси од една боја, и според нивните RGB (Red-Green-Blue) вредности беа одредени просечни вредности. Финалната палета е претставена преку новите RGB вредности и нивните соодветни кодови (сл. 103).

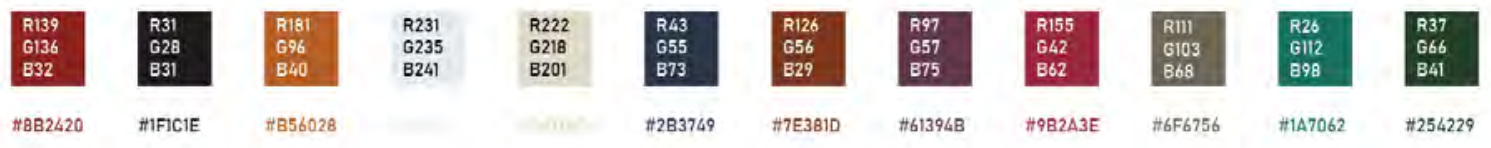

\section{Сл. 103. Палета на препознаените бои кај носиите}

Во колоритот на килимите се забележува доминацијата на црвени и кафени нијанси, но се препознаваат и многу секундарни бои (сл. 104. а,б,в). Имајќи ги предвид констатациите од претходната анализа на бои кај носиите, во овој дел повеќе внимание е обрнато на идентификувањето на дополнителни бои (сл. 104. г).
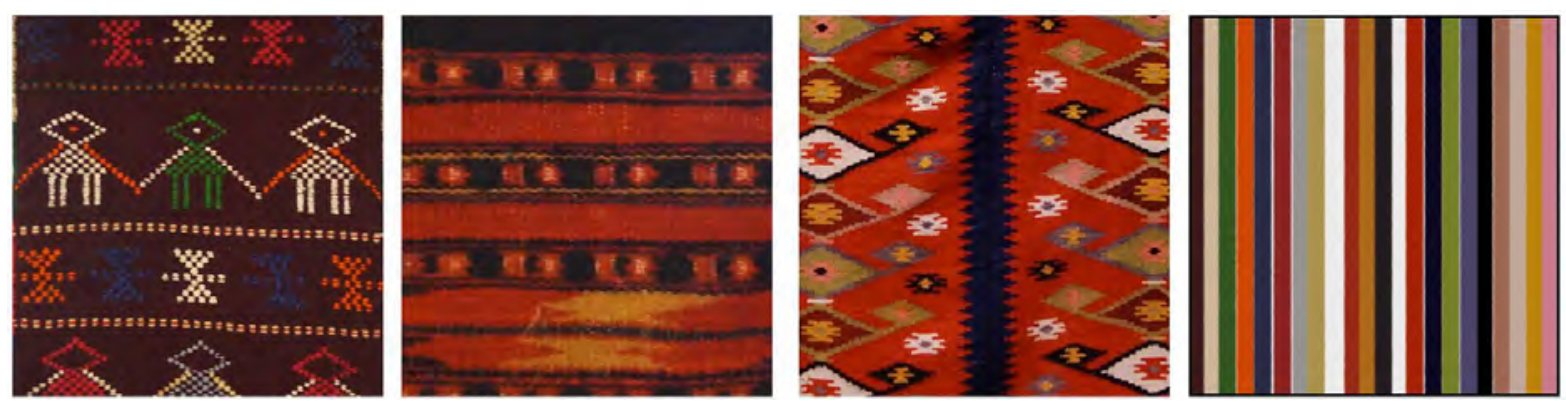

Сл. 104. а, б, в, г Бои кај килимите

Како дел од површинската обработка на грнчарските предмети, боите зависат од достапните природни материјали за пигментирање. Многу садови ја задржуваат нивната природна боја, поточно бојата зависно составот на глината. Бојата на глината може да варира од кафеаво-црвена, до окер-кафена. Во одбраните примери, боите од површинските обработки се сведуваат на кафена со бели детали, темно кафена и црна со бели, црвени, жолти и зелени орнаментални детали (сл 105. а-г). 

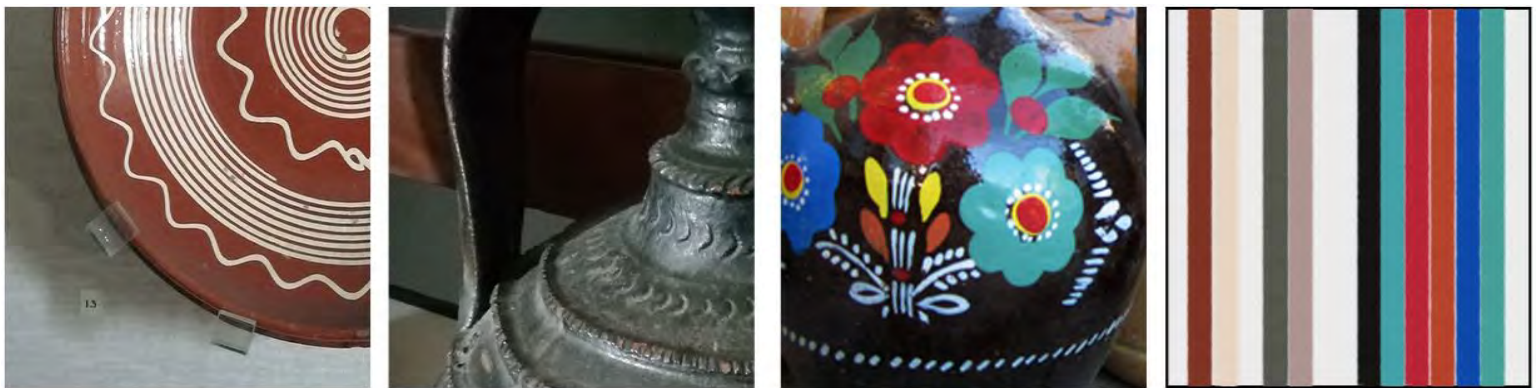

Сл. 105. а, б, в, г Бои кај грнчарските предмети

Металните предмети не се површински обработени со бои, но сепак имаат алтерации во бојата поради самиот материјал од кој е изработен предметот. Дополнително, врз бојата влијае и патината добиена со оксидација (сл 106. а-г).
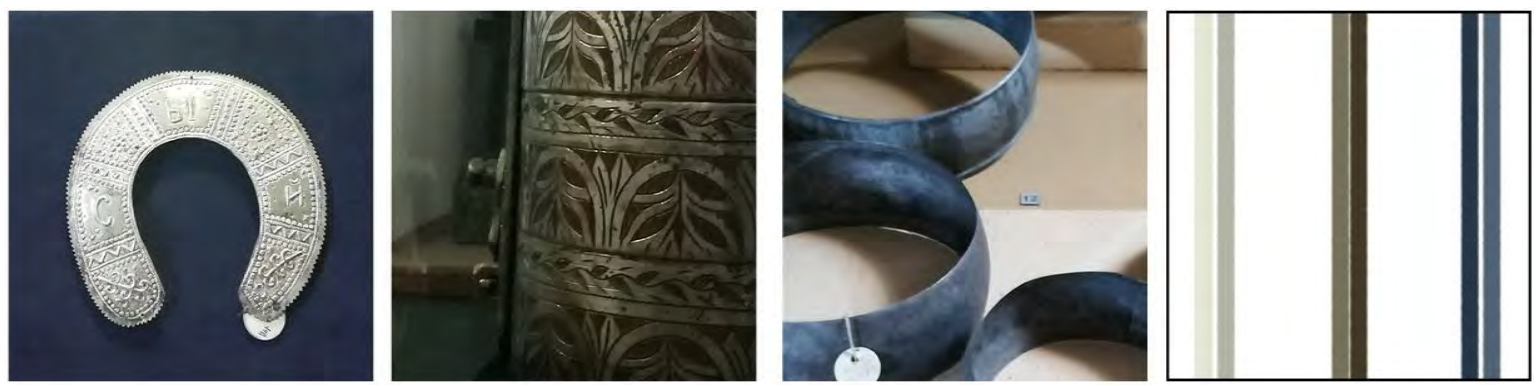

Сл. 106. а, б, в, г Бои кај металните предмети

Дрвените предмети вообичаено не претрпуваат никакви површински обработки или декорирања. Дадените примери и приложените предмети во Музејот на Македонија, независно од нивното потекло, ја задржале бојата на дрвото. Тоновите на дрвото зависат од атмосферските влијанија, термичките промени, долгогодишната употреба. Разликите во колоритот главно зависат од видот на дрвото употребено за изработката на овие предмети (сл. 107 a-г).
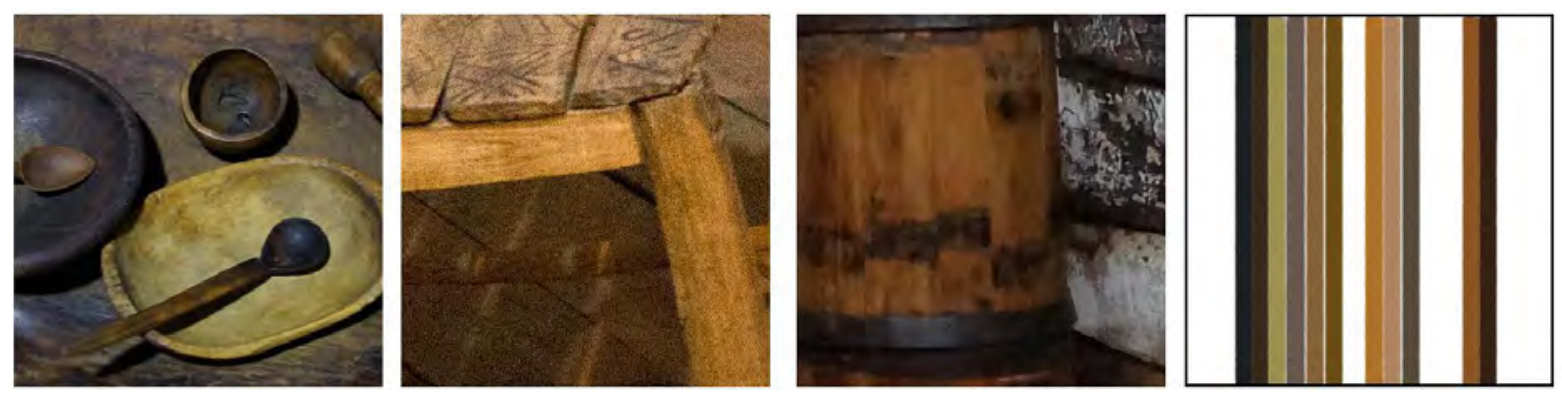

Сл. 107. а, б, в, г Бои кај дрвените предмети

\subsubsection{4. Материјал}

Најприсутните материјали за изработка на носиите се памукот, ленот и волната (сл. 108 а-г). Изработката на скутините и елеците е главно од волна, а на кошулите од памук и лен. Везовите се изработени од конци, но поради свечениот карактер на носијата, се гледа и присуство на свила и срма. Иако не се фокус на анализата, мора да се напоменат и секундарните материјали присутни на носиите, а тоа се метални (сребрени) токи и накит. Кај некои носии присутни и се монистри, синџири и гајтани, а понекогаш и кожа. 

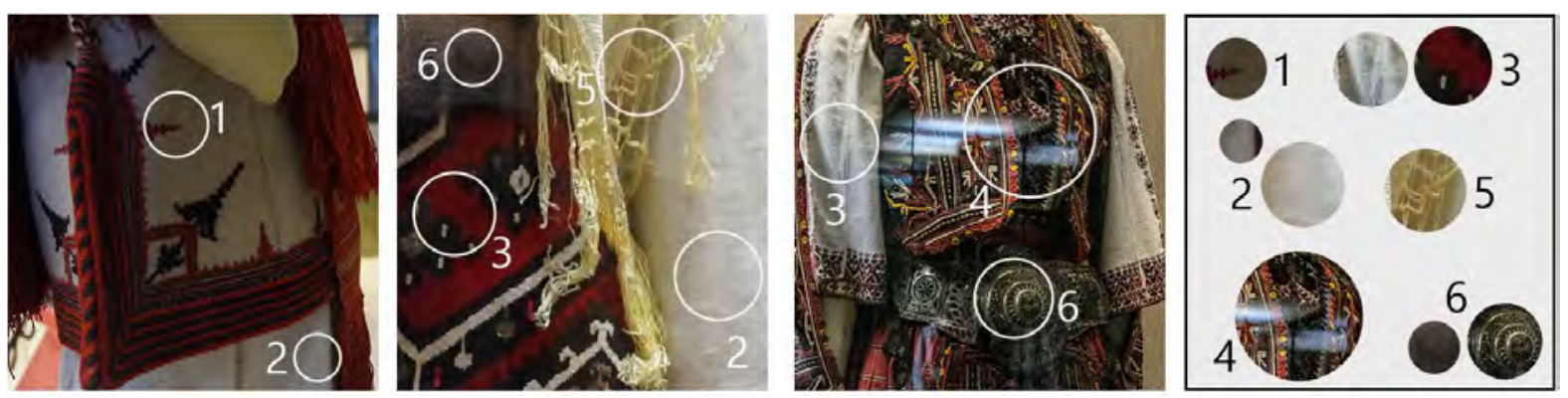

Сл. 108. а, б, в, г Материјали кај носиите

Килимите се изработувале од волна (сл 109. а-г). Шарите на килимите се оформувале при самото ткаење. Крутите дебели влакна од волна оформуваат структура од разиграни шари. Колку е подебел конецот. толку е поголемо и неговото влијание во идентификување на формите на шарите.
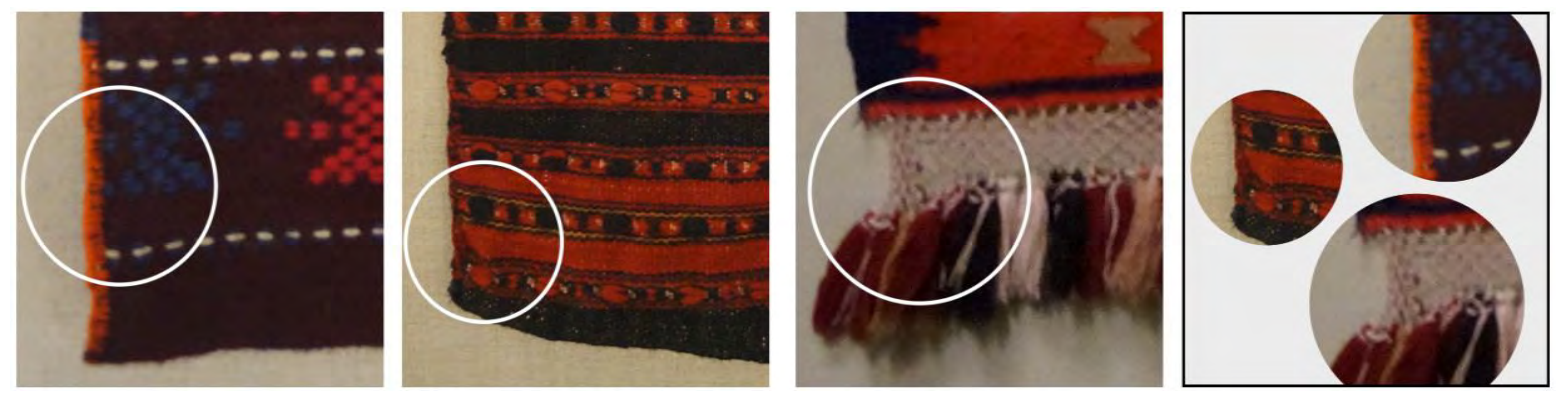

Сл. 109. a, б, в, г Материјали кај теписите

Грнчарските производи се изработувани од глина (сл. 110. а-г). Овој материјал дозволува изработка на различни форми, најчесто ротациони, со помош на грнчарско тркало. Притоа, битни фактори за нивниот квалитет се дебелина на sидовите, распределеноста на материјалот и соодносот на состојки, температурата на печење. Глината е подложна на лесна кршливост, но има одлична густина да задржи течности и издржливост на различни температури без да се оштети.
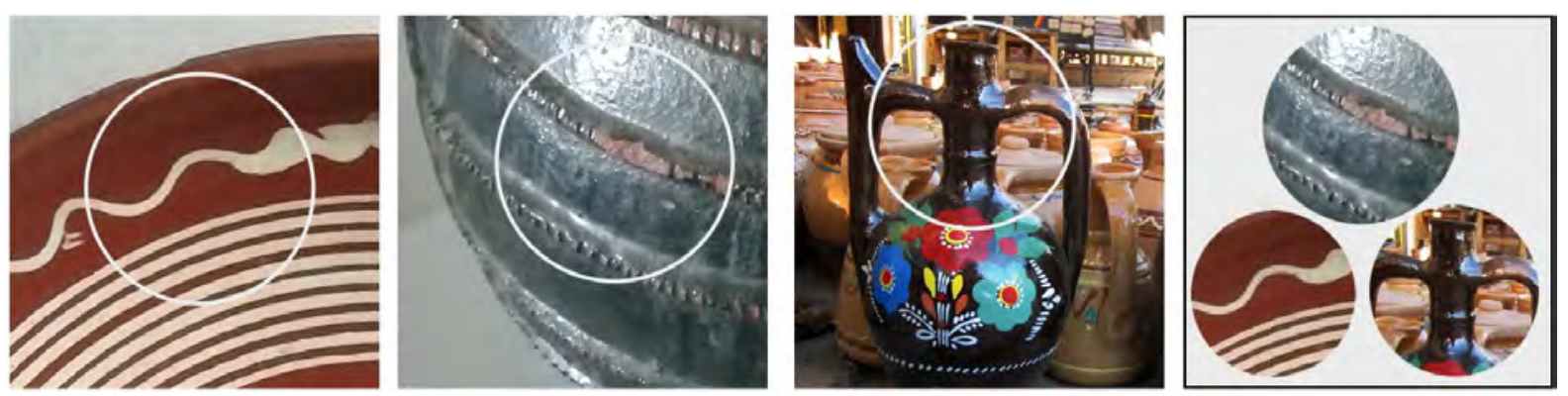

Сл. 110. а, 6, в, г Материјали кај грнчарските предмети

Најчесто применувани метали за изработка на производи за секојдневна примена во домовите биле бакар, цинк, железо, како и нивните легури бронза и челик. Поексклузивните предмети биле изработувани од злато и сребро (сл. 111 а-г). 

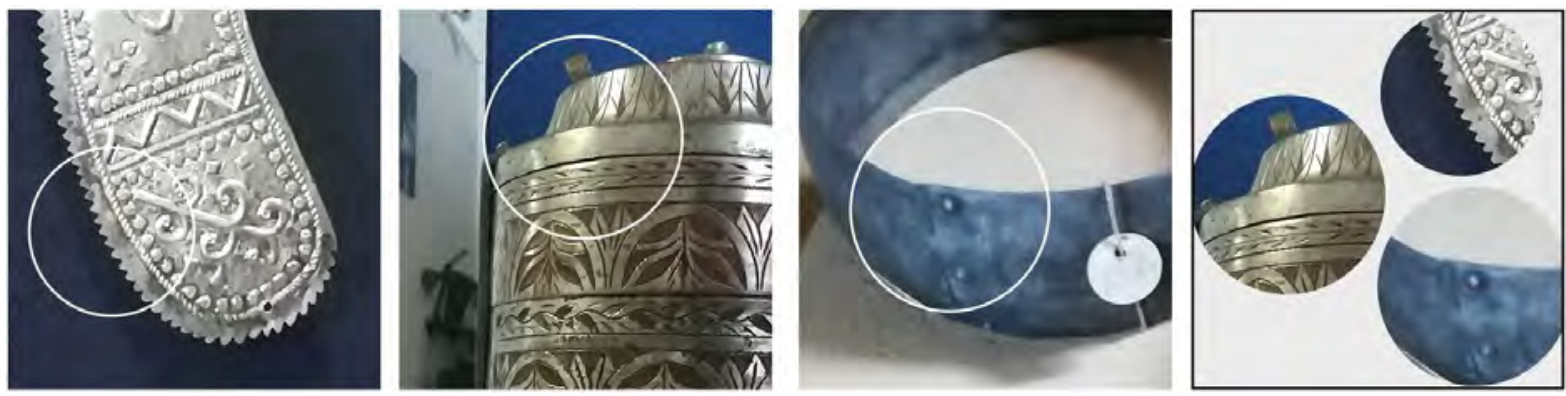

Сл. 111. а, б, в, г Материјали кај металните предмети

Дрвените традиционални македонски производи биле изработувани од најчесто застапените видови дрва на нашата територија: даб, бука, бреза, бор, габер, јасен, леска, врба, топола, смрека и други (сл. 112. а-г).
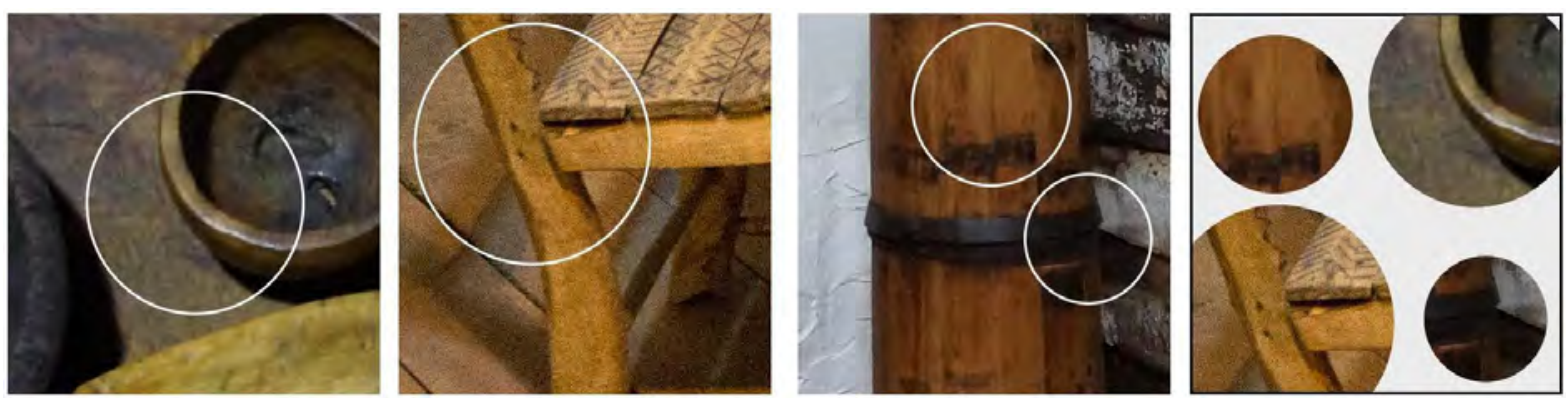

Сл. 112. а, б, в, г Материјали кај дрвените предмети

\subsubsection{5 Текстура}

Текстурата е забележлива на носиите и зависи од структурата на применетите материјали, како и од структурата и густината на конецот при креирање на формите и дезените кај везовите (сл. 113. а-г). Дел од парчињата облека кај носиите е изработен од памучна или ленена ткаенина со нежна текстура, а наспроти нив. елеците и скутините се изработени од погруба волнена ткаенина. Дополнително, везовите нудат богата и разиграна текстура која зависи од применетиот конец и неговата дебелина, како и структурата и густината на бодовите од везот.
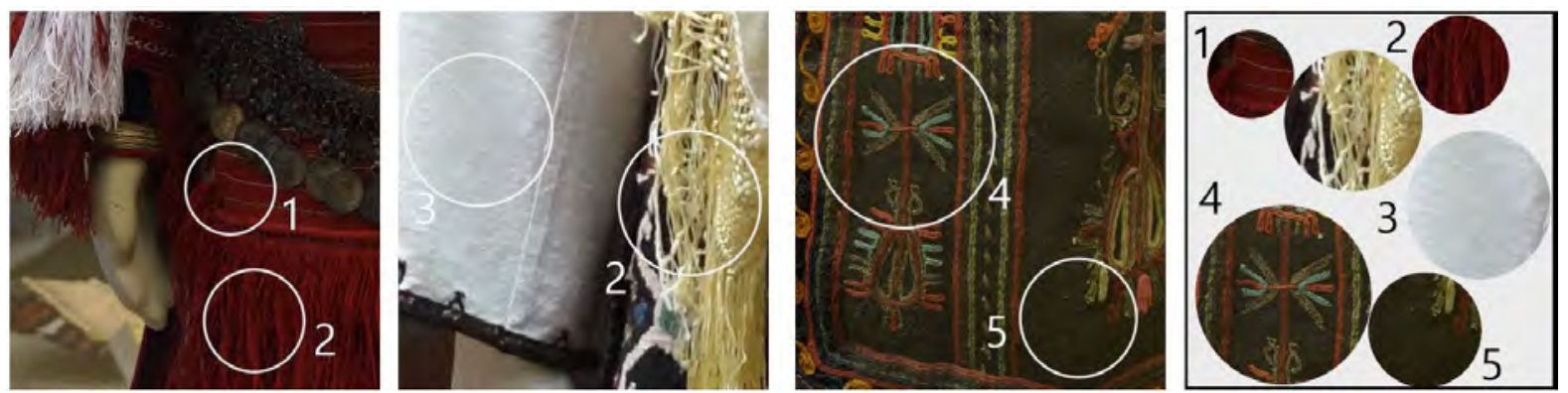

Сл. 113. а, б, в, г Текстури кај носиите

Кај ткаените килими текстурата зависи од волнениот конец, колку е покрупен, толку е погруба површината и обратно (сл. 114. а-г). Ткаењето на килимите се вршело на разбои. Најпрво се поставувала основата на килимот во вид на паралелно затегнати памучни конци, а потоа низ нив се провирал волнениот конец. Текстурата зависи од дебелината на двата вида конци, како и од нивната густина. 

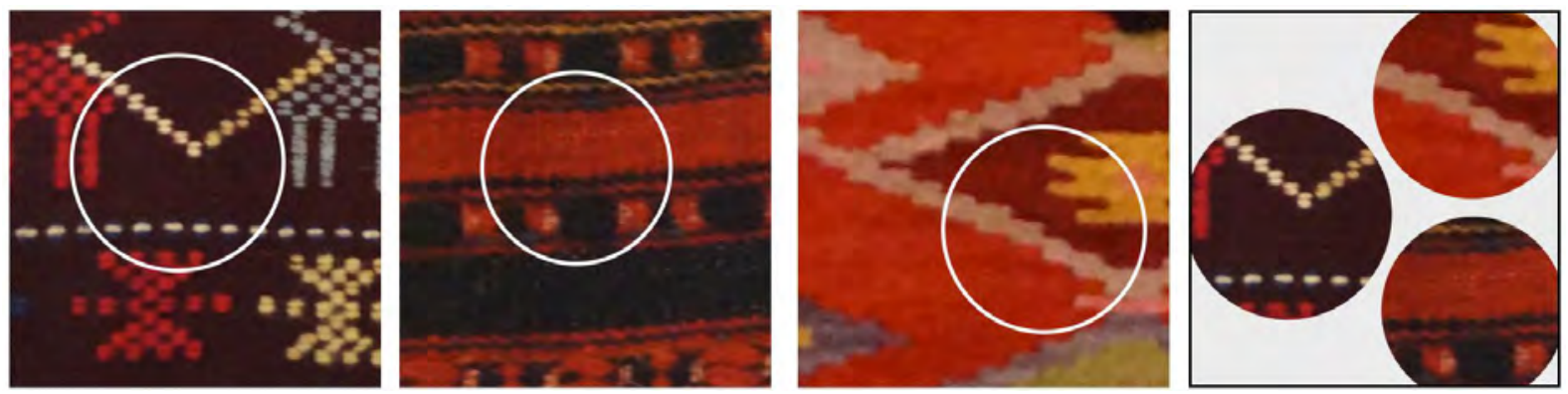

Сл. 114. а, б, в, г Текстури кај килимите

Производите изработени од глина имаат погруба текстура, но се среќаваат и декоративни рељефни елементи изработени од истиот материјал, кои со својата текстура го даваат конечниот ефект (сл. 115. а-г). Оригинално, овие производи се користеле без глазура, но во поново време се премачкуваат со лак или сјајна боја заради постигнување отпорност на вода, доколку се користат како кујнски садови.
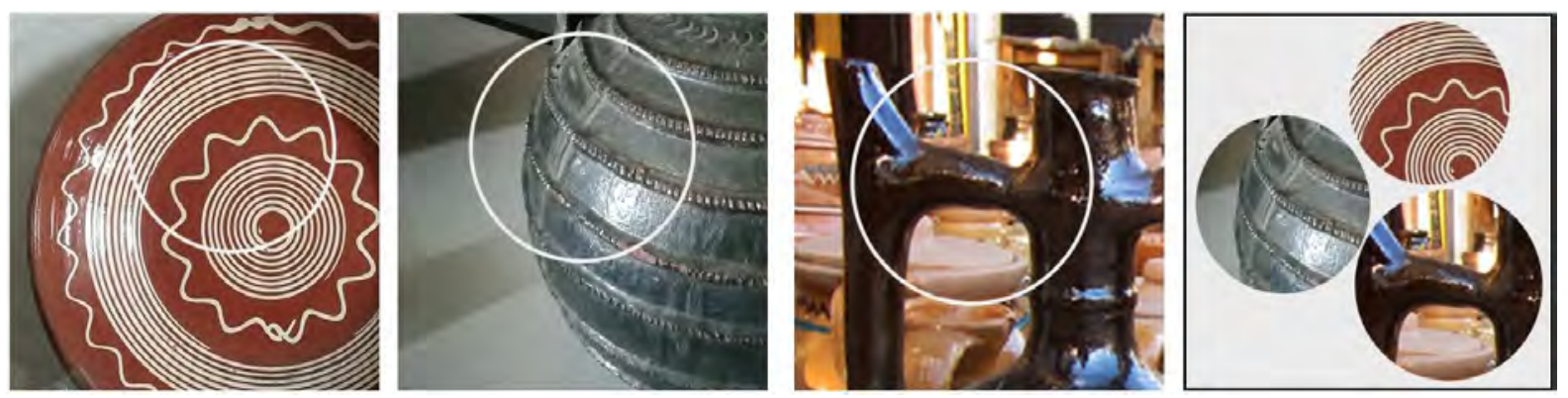

Сл. 115. а, б, в, г Текстури кај грнчарските предмети

Зависно од намената и бројот на обработки, така варира и текстурата кај металните предмети (сл. 116. а-г). Првиот и вториот пример имаат комбинирана мазна и груба текстура, поточно зависно од дистибуцијата на формите. Кованите елементи повеќе се испакнуваат во однос на главната рамнина. Едноставните функционални предмети имаат генерално мазна текстура.
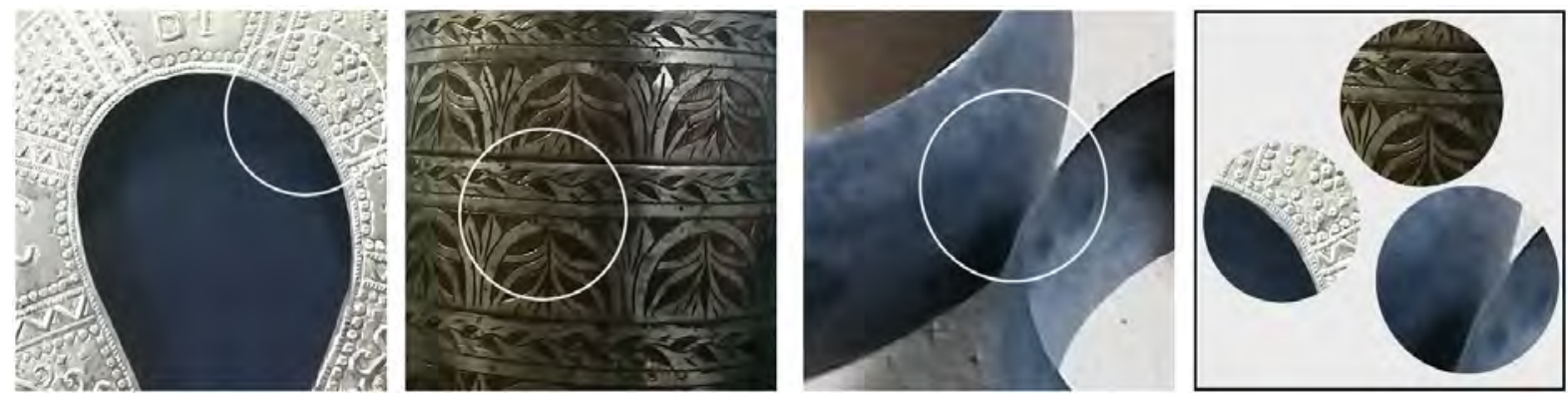

Сл. 116. а, б, в, г Текстури кај металните предмети

Поради ниското ниво на обработеност на дрвените предмети (сл. 117 а-г), текстурата е главно погруба кај производите за секојдневна употреба. Површинската текстура станувала мазна по долгогодишната употреба и изложеноста на влага. 

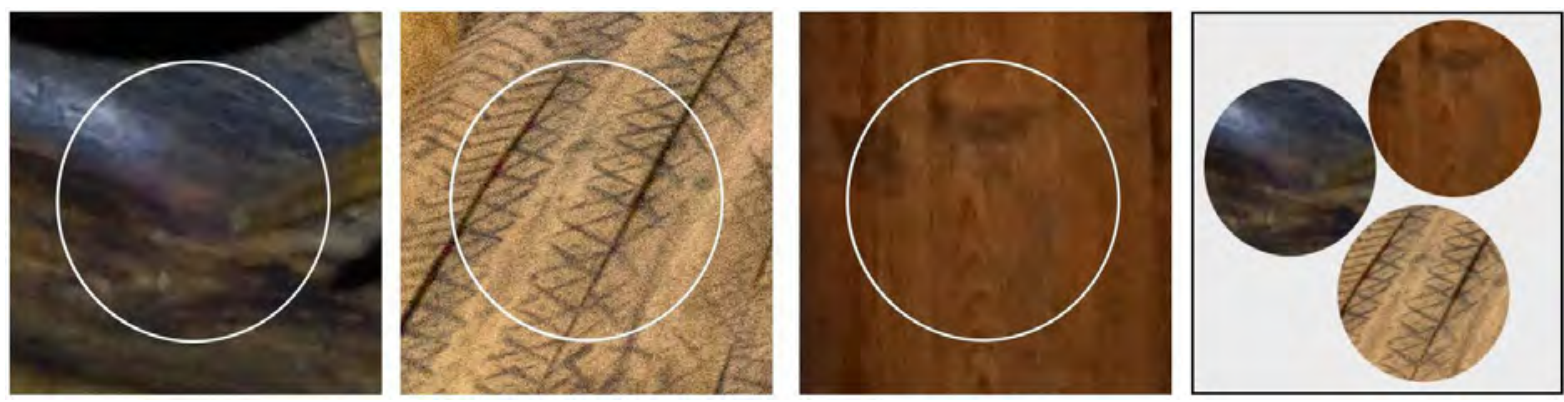

Сл. 117. а, б, в, г Текстури кај дрвените предмети

\subsubsection{5 Насока}

Насоката е визуелна сила која го води окото на посматрачот додека го набљудува делото. Кај оваа категорија производи насоката е анализирана кај шарите кои се највпечатлив дел на нивниот дизајн (сл 117 а-г). Доколку се постават замислени оски на везовите, може да се забележи генерално вертикална насока на формите на применетите шари. Доминантните линии во шарите на носиите, сугерираат ефект на рамномерен нагорен стремеж. Вертикалната насока може да се забележи јасно во композицијата од шари кои се поставени по некоја замислена вертикална патека, а кај самите шари честопати се применети и коси насоки.
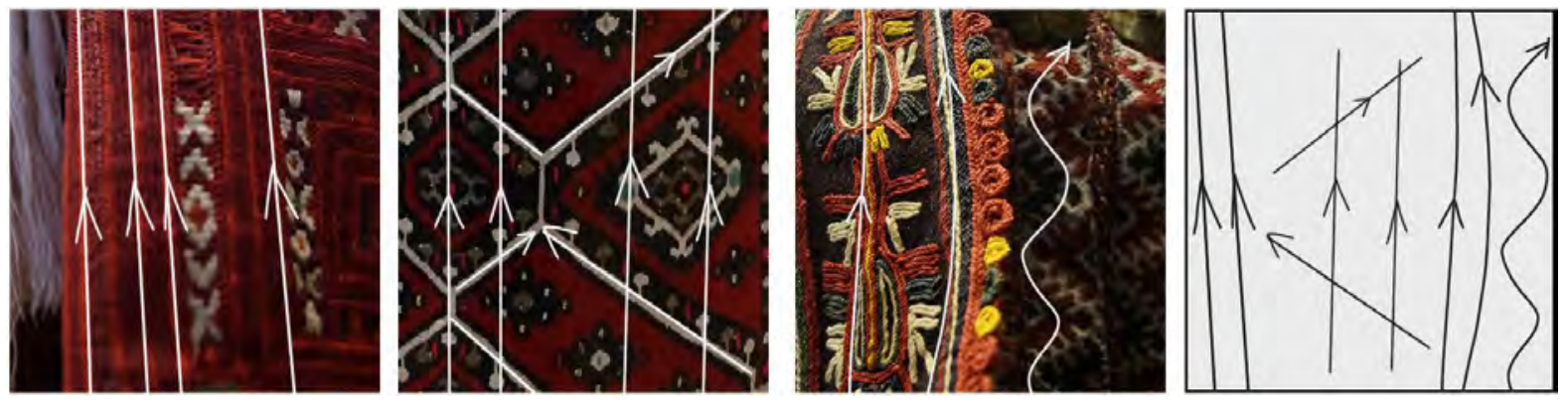

Сл. 118. a, 6, 6, г Насоки кај носиите

Генерално насоката кај шарите на килимите (сл 118 а-г) може да се разгледува од аспект на насоката на движење на конецот при ткаењето, кој е хоризонтален поради насоката во која што се одвивала изработката. Другиот аспект е анализа на насоките кај шарите на килимите и нивната поставеност во композиција. Најчесто се следи хоризонталата како насока на ритмичка репетиција на формите, но се применуваат и вертикална насока и коси насоки, а честопати и во комбинација.
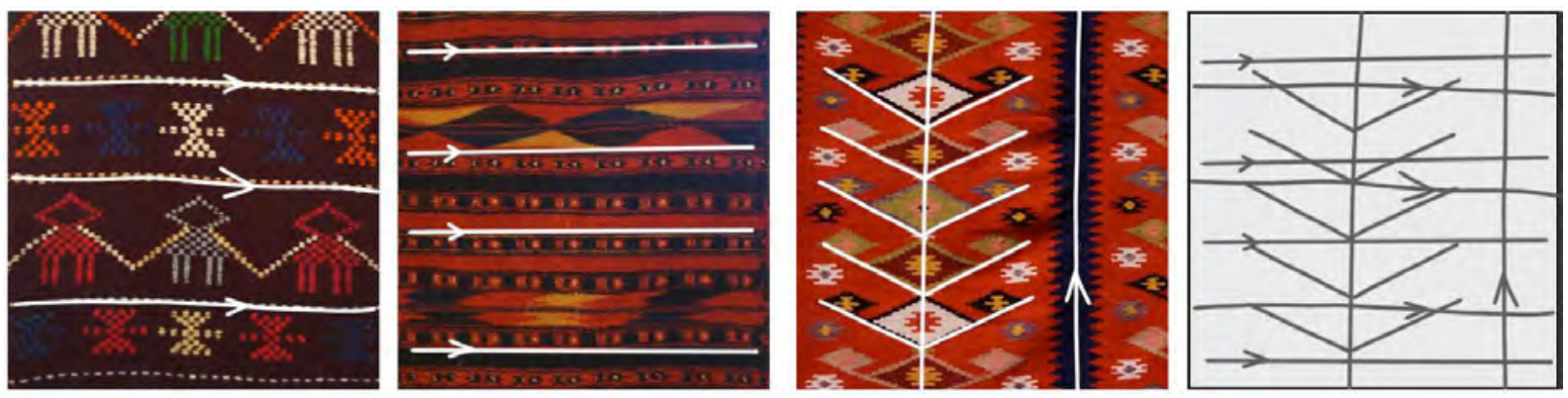

Сл. 119. а, б, в, г Насоки кај килимите 
Кај глинените садови насоката може да се анализира во однос на целокупната форма, но и во однос на применетите шари. Некои садови имаат, како форма, во целина, хоризонтална насока (првиот пример, сл. 119а), други вертикална (вториот сл. 996), додека во третиот пример (сл. 99в) присуството на држачите создаваат комбинација со подинамична коса насока. Првите два примера имаат шари со радијална, кружна, насока која ја следи глобалната насока на изработката, а кај третиот е застапена радијална насока на композицијата од шари.
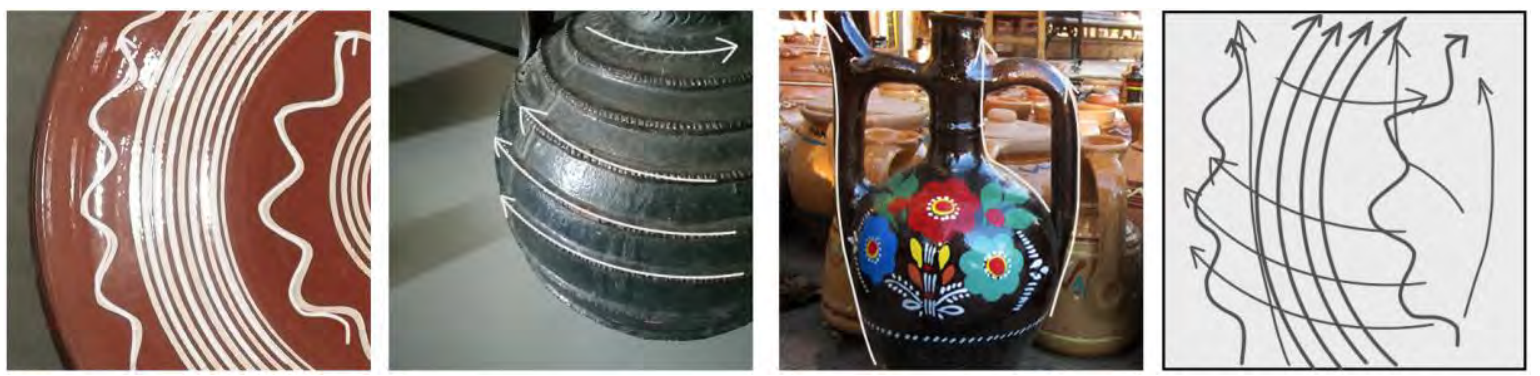

Сл. 120. а, б, в, г Насоки кај грнчарските предмети

Очигледна е кружна насока на распоредот на декоративните елементи во овие три примери на метални производи. Перфорираните декоративни елементи ја следат полукружната насока на огрлицата (сл. 120 a), но се забележуваат и мали симетрични групи на елементи што се движат радијално во однос на замислениот центар на кружницата. Кај ќупот (сл. 120 б), формата има изразена вертикална насока, а изрезбаните декоративни елементи се движат по хоризонтални кружници распоредени по надворешноста, со што ја нагласуваат вертикалната насока на целиот производ. На последниот предмет (сл. 120 в) нема површинска орнаментација за анализирање, но самата форма има кружна насока.
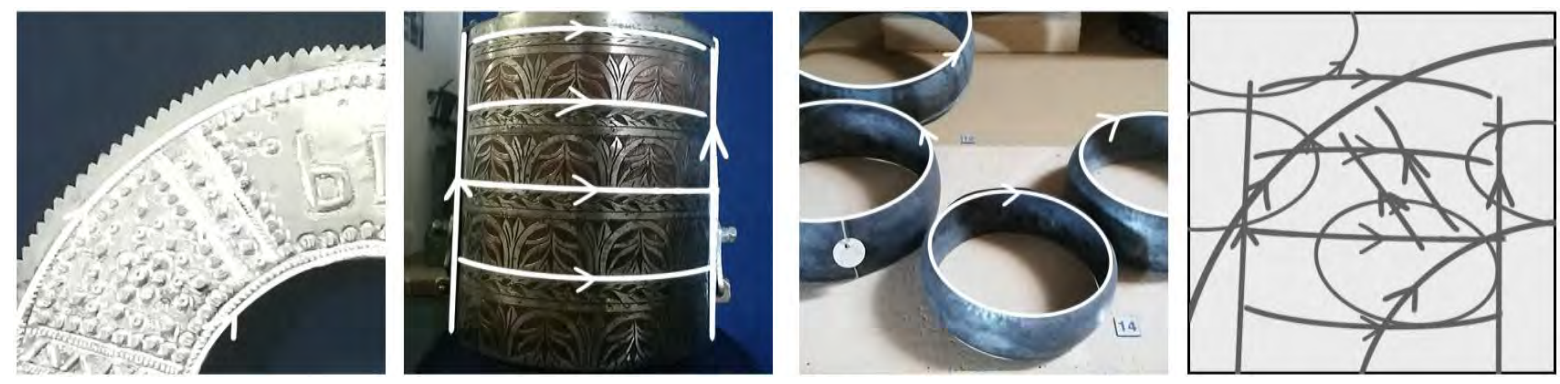

Сл. 121. а, б, в, г Насоки кај металните предмети

Кај столицата како целина (сл. 1226). насоката ја диктира ногарката каде што вертикалната насока полека станува закривена нагоре по наслонот за грб со цел да обезбеди поголема удобност. Кај бучимот (сл.122 в) кружните хоризонатални метални профили за спојување на вертикалните сегменти ја потенцираат вертикалната насока.
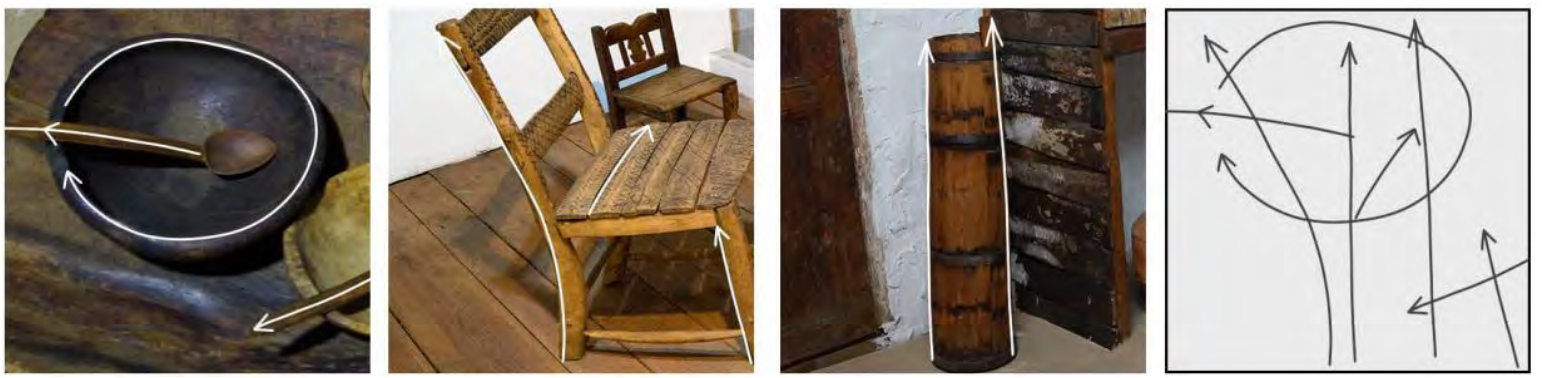

Сл. 122. а, б, в, г Насоки кај дрвените предмети 


\subsubsection{6 Големина}

Големината како дизајн елемент може да се анализира од два аспекта: како целосниот објект кореспондира во однос на неговата околина или како разлики во големините на одделни делови од целокупната форма.

Се забележуваат вообичаени големини на сите одделни елементи, парчиња, кај различните видови носии (сл. 123. а-г). Притоа, разлики се забележуваат кај големините на шарите, па дури и големините на сребрените пафти како доминантен украс.
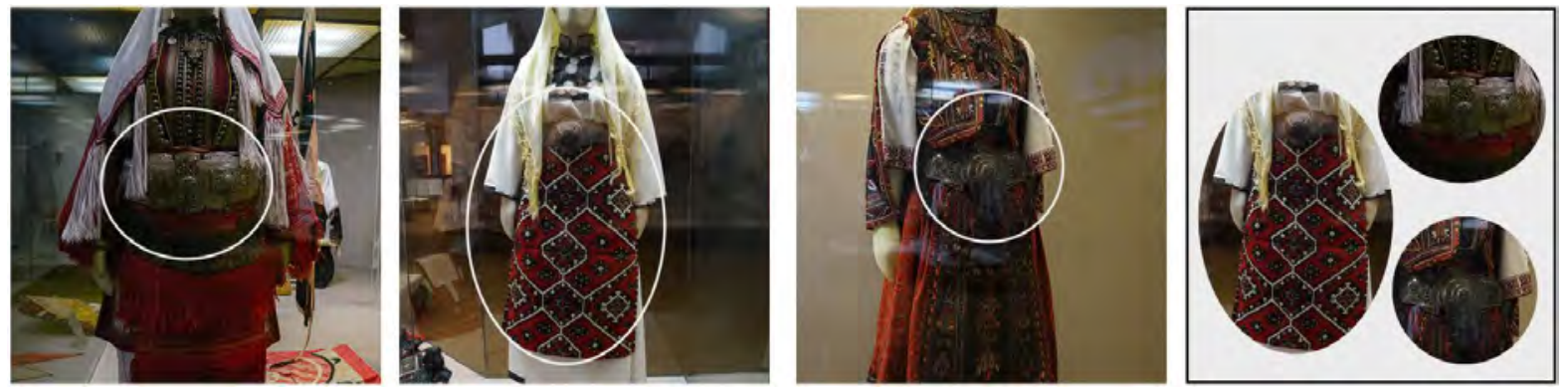

Сл. 123. а, б, в, г Големина кај носиите

Кај килимите се користат бројни карактеристични шари, нивни комбинации, алтерации и репетиции, кои најчесто се однесуваат на примена на исти шари во различни големини. Притоа, ниту една од нив не се натпреварува за внимание за да се препознае како фокална точка (сл. 124. а-г).
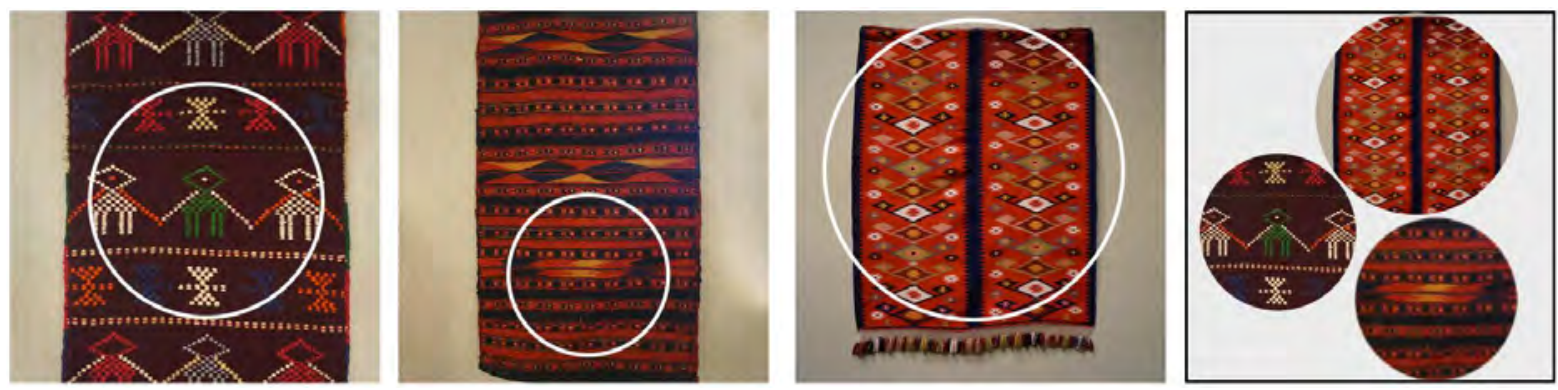

Сл. 124. а, б, в, г Големина кај килимите

Грнчарските елементи се изработувани во различни големини од функционален аспект. Друга анализа кај нив може да се однесува на соодносот на големините на различните делови од целокупната форма, но и на нивните шари (сл. 125. а-г).
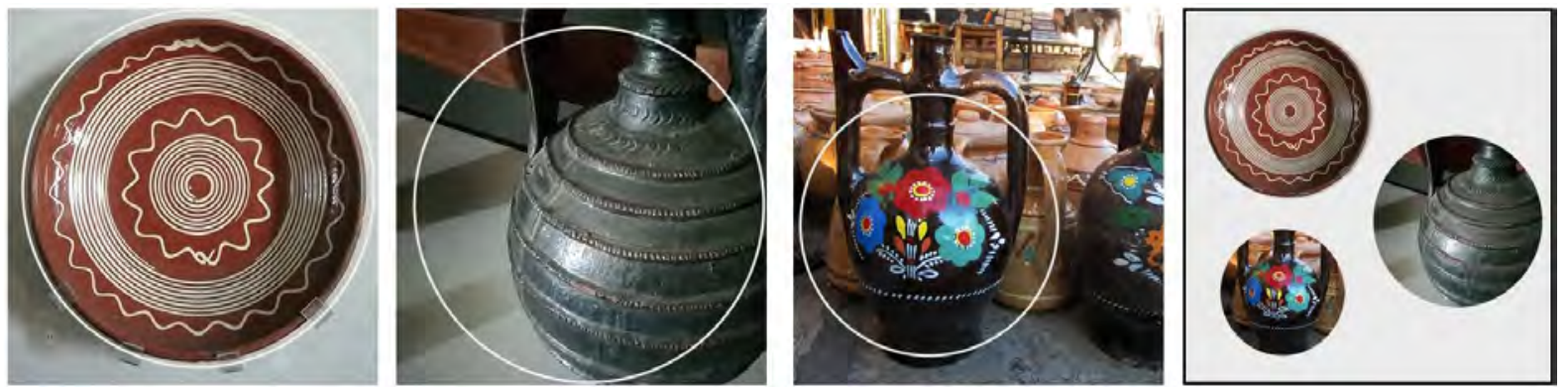

Сл. 125. а, б, в, г Големина кај грнчарските предмети

За избраните примери метални предмети, може да се изврши анализа на дизајн елементот големина на сличен начин како кај глинените предмети. Големината на нивните 
форми зависи од нивната функционалност. Големината како елемент е поприсутна кај декоративните шари. Се забележуваат шари кои се повторуваат со иста или со различна големина, а притоа е важен и нивниот сооднос (сл. 126 а-г).
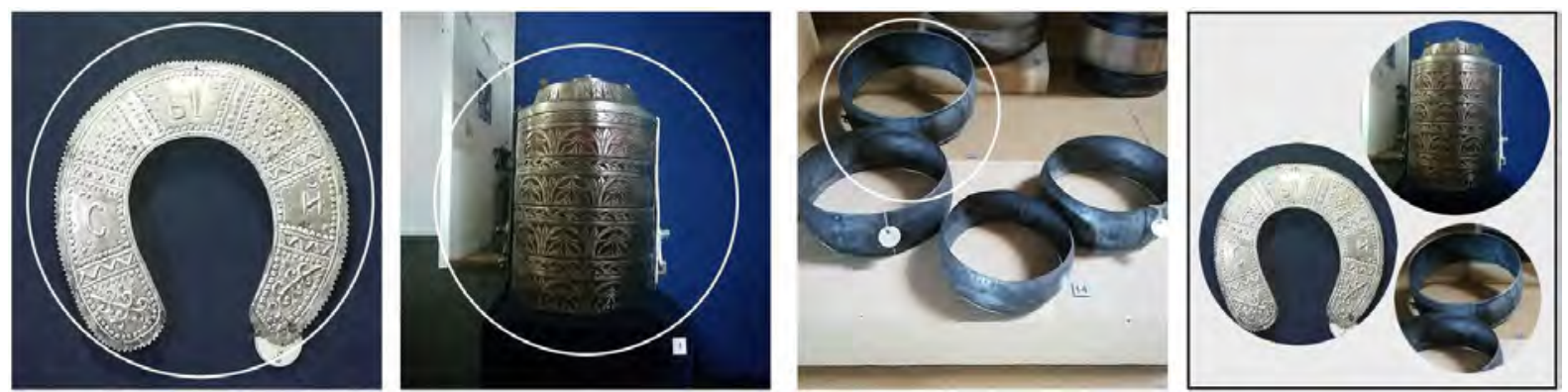

Сл. 126. а, б, в, г Големина кај металните предмети

Избраните дрвени предмети имаат исклучиво употребна функција и нивните големини се прилагодени на антропометријата на корисниците. Од аспект на големината како дизајн елемент не се интересни за дискусија (сл. 127. а-г).
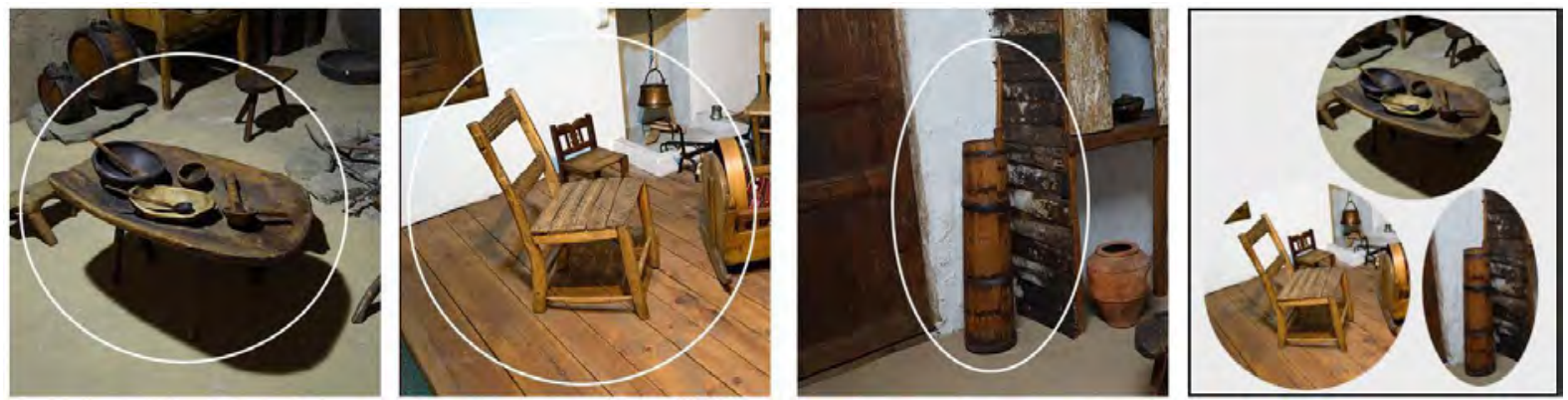

Сл. 127. а, б, в, г, Големина кај дрвените предмети

На крајот од оваа анализа даден е преглед на извлечените дизајнерски елементи по категории предмети со примена на деконстуктивизмот на Чуми (сл. 128. - 132.). 


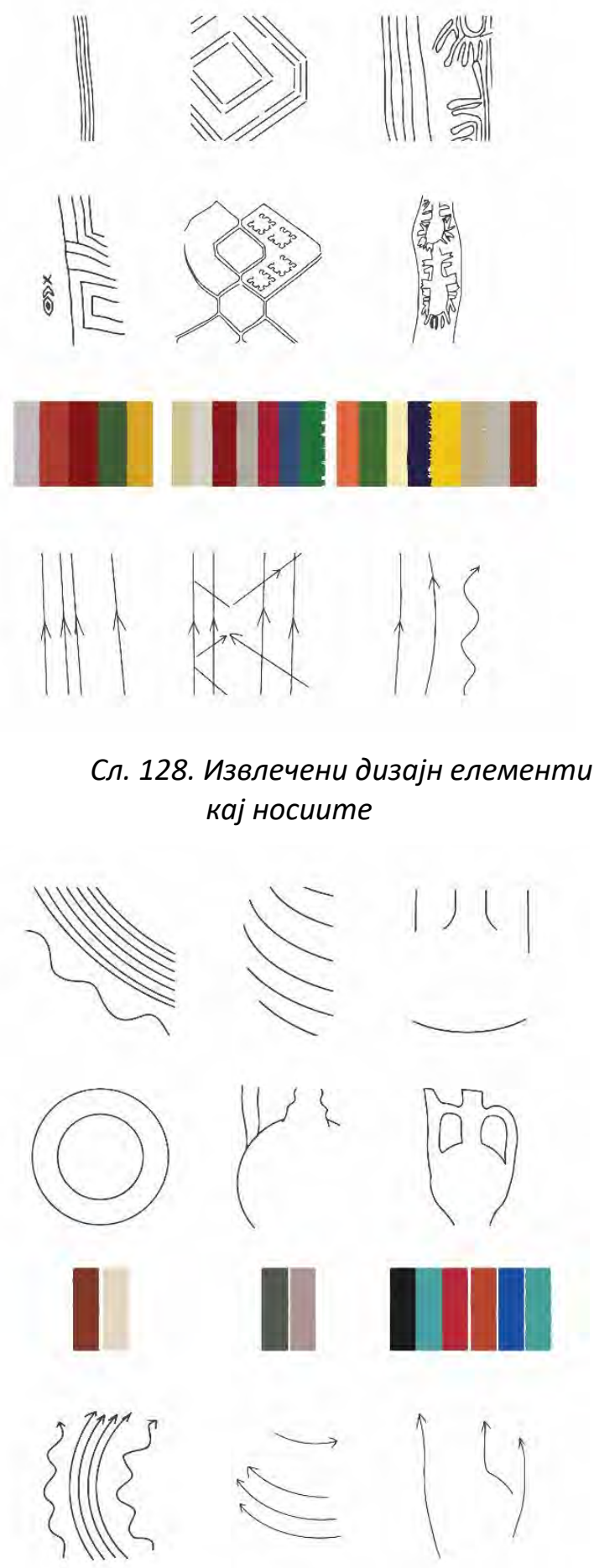

Сл. 130. Извлечени дизајн елементи кај избраните грнчарски предмети
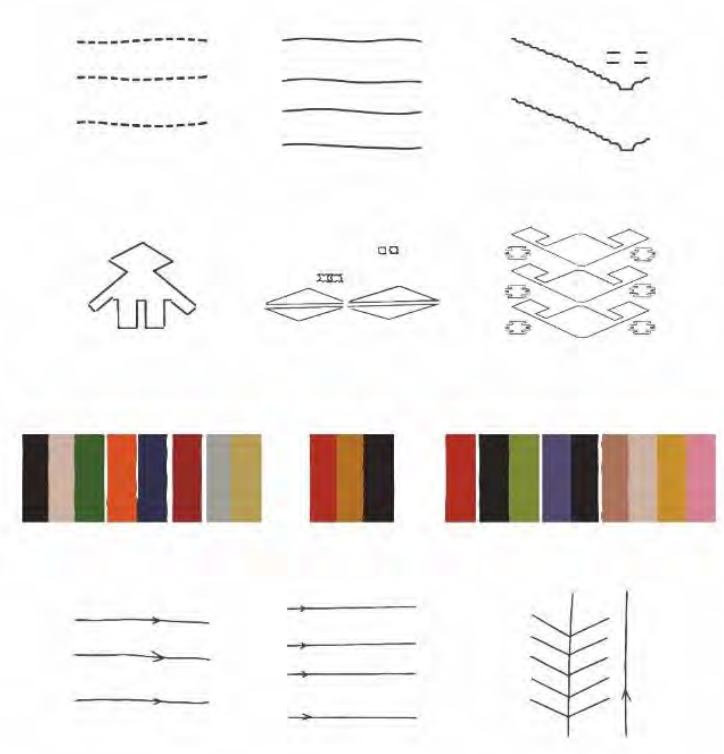

Сл. 129. Извлечени дизајн елементи кај килимите
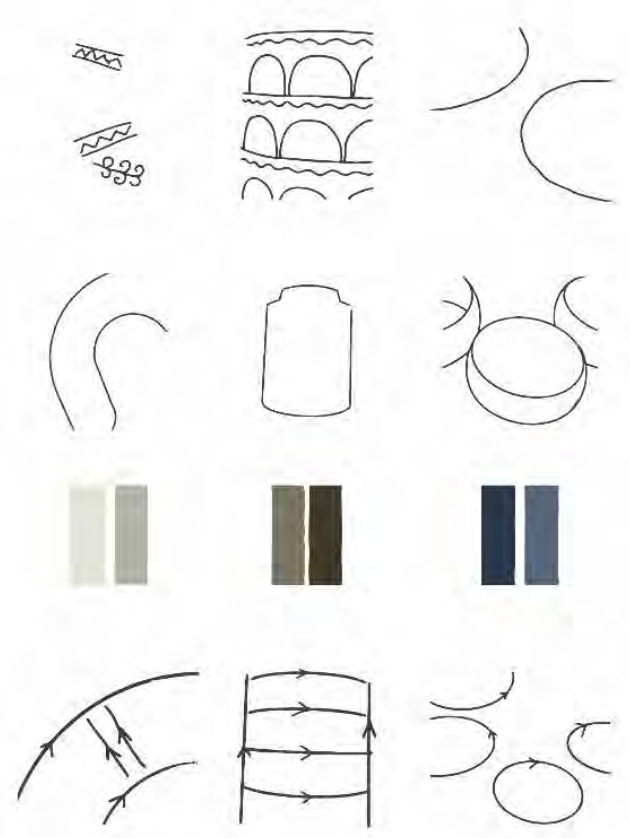

Сл. 131. Извлечени дизајн елементи кај избраните метални предмети 

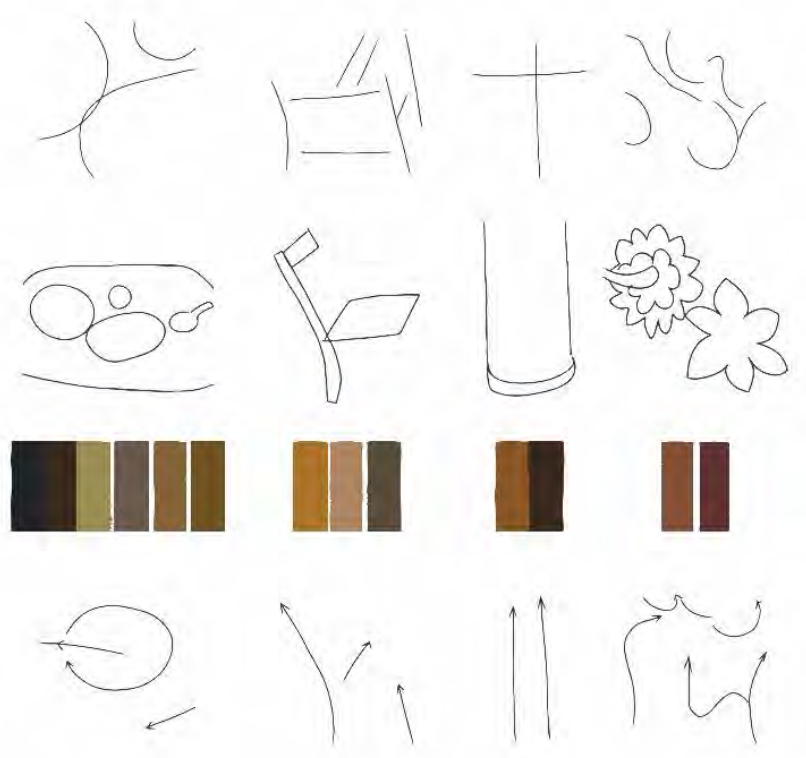

Сл. 132. Извлечени дизајн елементи кај избраните дрвени предмети

\subsection{2 Анализа на дизајн принципите по категории производи}

Анализата на применетите дизајн принципи е извршена посебно за сите групи избрани традиционални производи. На тој начин се добива посеопфатна слика за применетите дизајн елементи во цврсти композиции.

\subsubsection{1 Дизајн принщипи кај носиите}

Носиите како целина се карактеризираат со богат колорит со бројни контрасти (сл. 133). Наспроти белата позадина на кошулата, рабовите на ракавите се извезени со шари во доминантни површини со црвена боја, а помали количини на црна, сина, зелена и жолта боја. Кај скутините и елеците се применети истите бои, но контрастот не е толку силен поради отсуството на големата бела површина на кошулата, иако истата е подискретно применета во дизајнот на шарите. Шамиите кај галичката и кривопаланечката носија и ракавите на сите носии се еднобојни, со исклучок на рабовите, каде што се појавува низа везени елементи или ленти и гајтани од друг материјал.
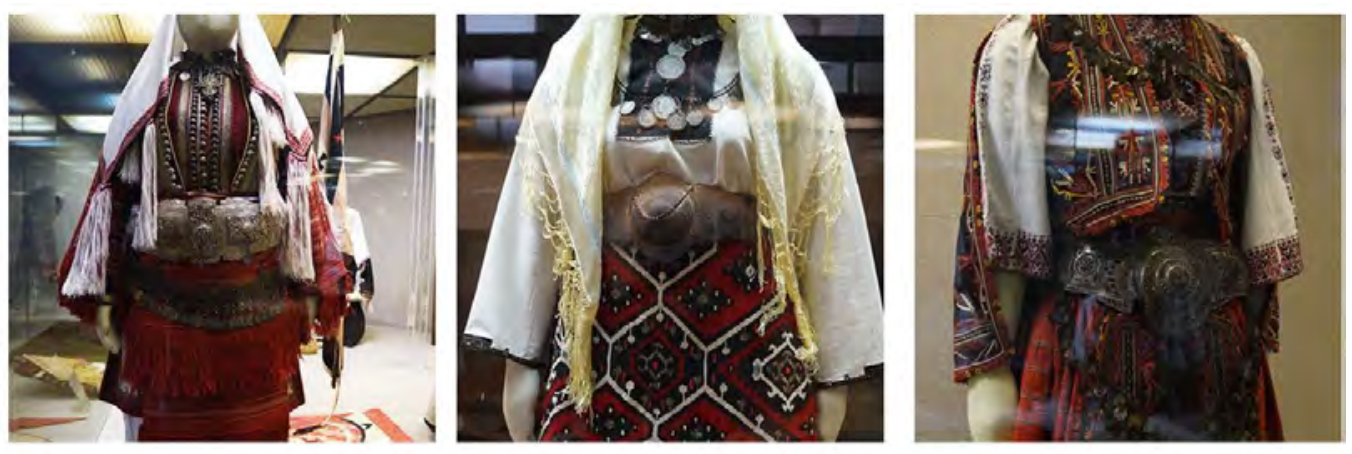

Сл. 133. а, б, в Избрани носии за анализа 
Големи контрасти во дизајнот на носиите се забележуваат и во примената на материјалите. Нежната текстура на белата кошула е во контраст со рапавите текстури на везовите и грубата текстура на ткаените скутини. Особено е впечатлив контрастот меѓу униформните текстилни делови и големата сребрена пафта, поставена на појасот, која станува еден вид фокална точка и обезбедува доминација во дизајнот на целата носија.

Во однос на примената на принципот пропорција може да се заклучи дека носиите ги следат човечките пропорции, каде е најмногу застапен златниот пресек. Деловите од носиите се во меѓусебен однос кој соодветствува на човечките пропорции, кај нив безимените автори интуитивно го следеле златниот пресек (сл. 134. а,б,в).
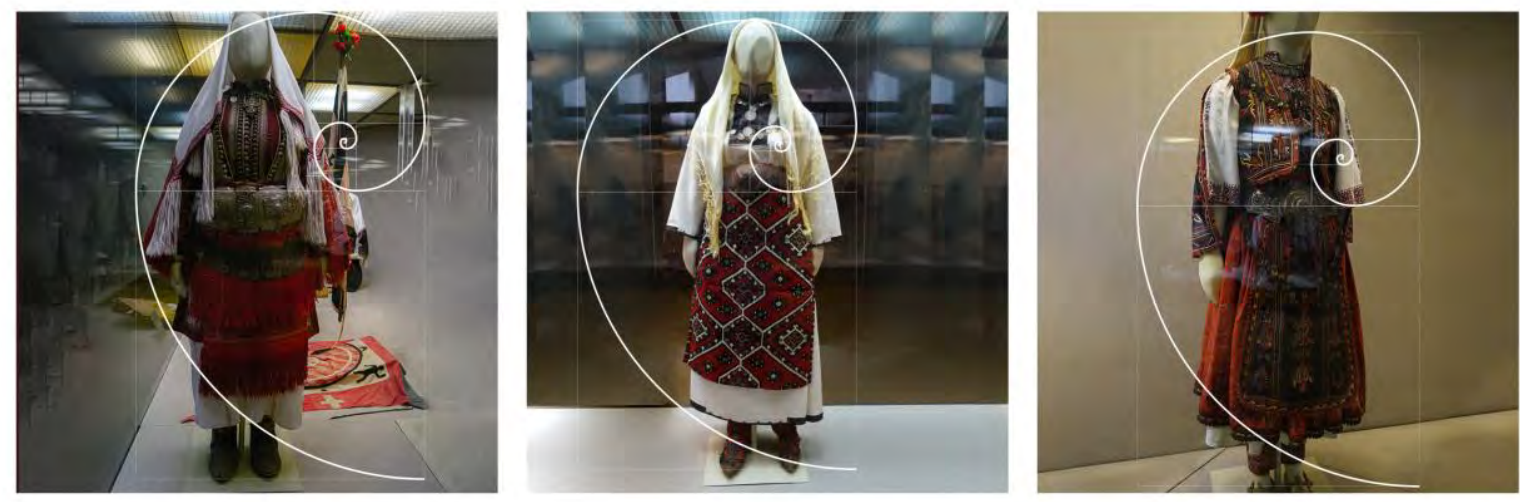

\section{Сл. 134. а, б, в Златниот пресек забележан кај носиите}

Рамнотежата кај носиите е симетрична во однос на замислена вертикална оска, следејќи ја симетријата на човечкото тело. Композицијата на носијата како една целина, едно дело, е вертикална.

Посебен предизвик за анализирање на применетите дизајн принципи кај носиите се декоративните елементи - шарите на скутините, елеците и ракавите на кошулите. Шарите на ткаените скутини во вториот пример (сл. 1356) се карактеризираат со специфична геометрија, најчесто се квадратни, ромбоидни и шестоаголни форми, комбинирани во посложени, со примена на градацијата како принцип и богата ритмика со хармонични форми кои се повторуваат. Насоката на овие форми е најчесто искосена, со што се добива впечаток на раздвиженост и динамика.
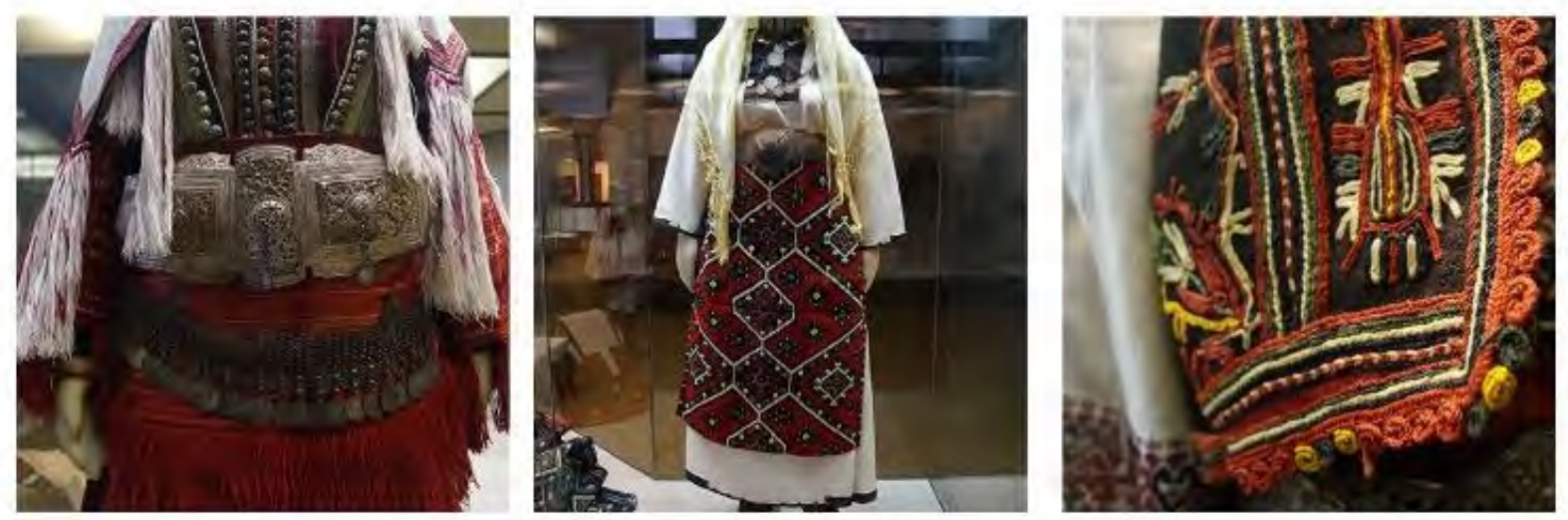

Сл.135. а, б, в Принципи на дизајн кај шарите на носиите 
Шарите кај третиот пример (сл. 136в) од носиите имаат пооргански форми, во контраст со хоризонтални и вертикални паралелни линии и кружни детали поставени во хоризонтални и вертикални низи. Тие најчесто претставуваат поедноставена презентација на урнеци од природата (цветови, гранки, инсекти). Традиционалните безимени уметници имале исклучително чувство за поедноставување и стилизација на урнеците од природата од кои се инспирирале.

Ритамот во шарите кај носиите е доминантно алтернативен. Најчесто елементите, шарите, следат отворена низа во нивниот ритам, при што се забележува алтерирање на боите на одреден чекор.
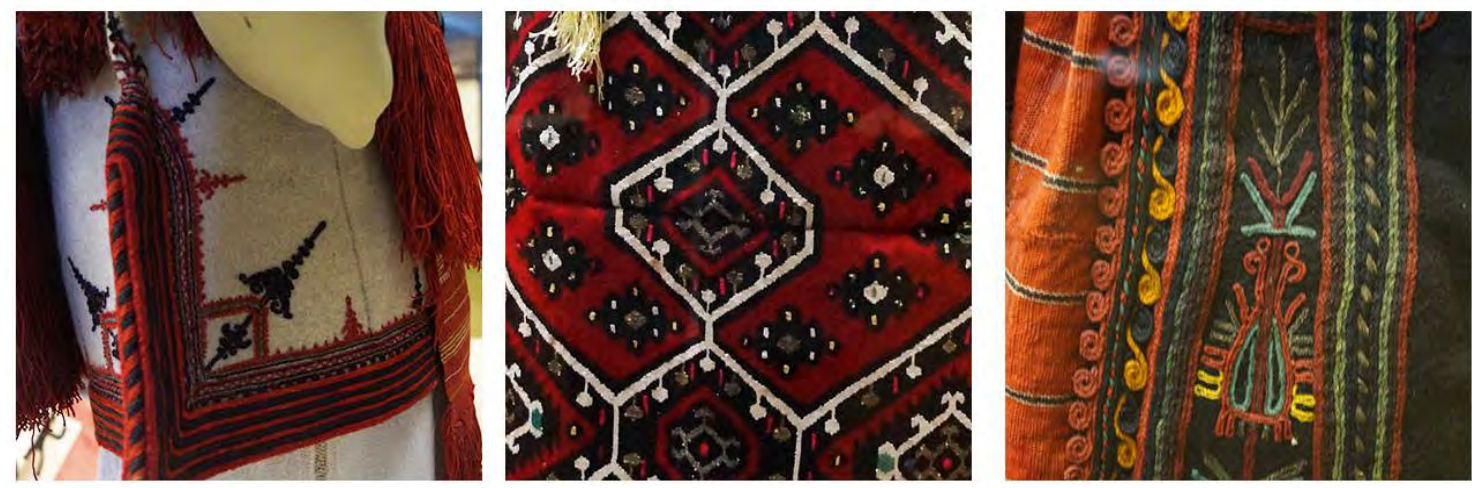

Сл.136. а, б, в, Пропорции кај шарите на носиите

Пропорциите кај шарите на ткаената скутина од вториот пример (сл. 136б) сугерира модуларен пристап со форми на шарите кои покажуваат сложена геометрија, базирана на квадрати кои постепено се зголемуваат, со меѓусебен однос на страните близок до златниот пресек. Од истите слики може да се препознае примена на мрежеста композиција која овозможува правилен сооднос на големините на одделните шари, како и нивното меѓусебно растојание.

Повторувањето и сличноста на формите кај шарите на носиите, како и нивната рамномерна распореденост, ритмичноста и симетријата, обезбедуваат впечаток на единство во дизајнот на носиите како целина и како одделни делови со специфични декоративни елементи. Изборот на бои, рамномерната употреба на контрасти, подредувањето на елементите по дефинирани правци, дозволуваат сите делови на носијата да функционираат како една целина во единство.

\subsubsection{2. Дизајн принщипи кај ткаени килими}

На прв поглед, во дизајнот на килимите може да се идентификуваат големи сличности со носиите, особено со ткаените елементи - скутините. Применет е богат колорит и форми. Во дизајнот на килимите се забележува хармонија во примената на паралелните прави линии, кои потекнуваат од технологијата на изработката и во примената на геометриски шари. Но, општиот впечаток е дека доминираат претежно контрасти, пред сѐ во применетиот колоритот кој е сличен како и кај носиите. Доминираат површини во црвена боја, во неколку препознаени нијанси, а потоа и детали во црна, бела, зелена, сина и жолта боја. Овие комбинации претставуваат доста силен контраст во кој се вклучени примарните бои и црната и белата како 
најсилен контраст. Контрастот се забележува и во насоките. Наспроти доминантните хоризонтални линии кои ја следат насоката на ткаењето, геометриските шари, кои се најчесто ромбоидни, имаат коса насока, со што е постигната разиграност, раздвиженост и динамика (сл 137. а-в).
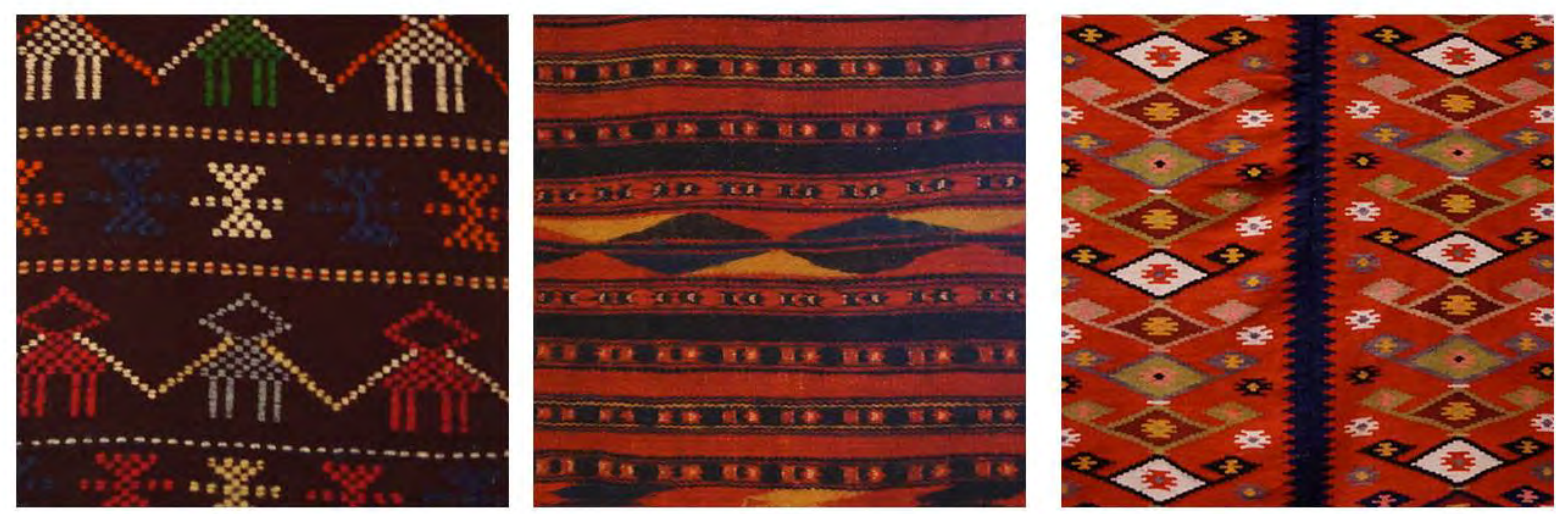

\section{Сл. 137. а, б, в Дизајн принципи применети кај ткаените килими}

Формите на шарите применети кај ткаените килими следат рамномерен број чекори, задржуваат иста пропорција на висината и ширината кај сите нивни повторувања и следат доминантно хоризонтална насока на подредување. Повторувањето слични елементи и нивниот еднаков чекор на повторување со други, меѓусебно слични елементи, се знак на добра пропорција.

На сите три примери може да се препознаат применетите Гешталт принципи, кои безимените автори ги применувале интуитивно. Принципот фигура - позадина ги истакнува еднобојните униформни елементи врз еднобојните позадини во вид на раздвижени форми. Односот позадина наспроти форма, поточно карактеристиките на елементите кои се идентификуваат како позадини наспроти формите врз нив, се во најголем контраст во однос на другите елементи.

Нештата кои се слични врз база на нивната боја, форма, насока итн., се доживуваат како поврзани. Во случајот на првиот килим (сл 137. а), поголемите форми ги чувствуваме како поповрзани за разлика од формите меѓу нив. Тука голема улога игра и законот на единство или униформната поврзаност, елементите со визуелна поврзаност се перципираат како поповрзани. Дополнително може да се додаде дека е применета мрежестата композиција со која е постигната добрата пропорција.

Принципот на едноставноста, стилизирање, се забележува кај сите примери во вид на поедноставување на форми преземени од природата. Човековата потреба за препознавање на формите и споредба со оние кои се сместени во неговата меморија, е позната како „правило на минато искуство“ од Гешталт психологијата. Со примена на ова правило, може да се заклучи дека формите од шарите во дизајнот на прикажаните килими се всушност поедноставени форми од природата. Безимениот автор, кој интуитивно го користел ова правило, креирал шари преку инспирација од природата. На првиот пример (сл. 137а), тоа се човечки фигури фатени за раце како да играат оро. Вториот пример (сл. 137б) содржи главно геометриски шари во кои не се препознава потеклото на инспирацијата. Во третиот пример (сл. 137в), сложените геометриски форми се поедноставени цветови или листови од растенија. 
Килимите следат поинаков тип на ритмичност во однос на носиите. Додека ритамот кај носиите има поврзаност со ритамот на музиката, при што бројот на повторувања и промени зависи од ритамот на музиката, во дизајнот на килимите се следи послободен ритам. Во сите три примери ритамот е алтернативен. Во првиот пример (сл. 137а) тој е поврзан со вертикалната симетрија, во вториот (сл. 137б) неколку низи елементи имаат регуларен ритам, додека секоја трета низа претрпува промена на боја, форма или чекор. Последниот пример (сл. 1376) е најдобар репрезент на алтернативниот ритам.

Објаснување: доколку секоја боја се означи со број, 1 = бела, 2 = зелена, 3 = црна и 4 = окер, тогаш поголемите форми го следат правилото 1213121 додека централните форми го следат правилото 242 4, при што секоја зелена форма мора да падне врз бела основа (сл. 138).
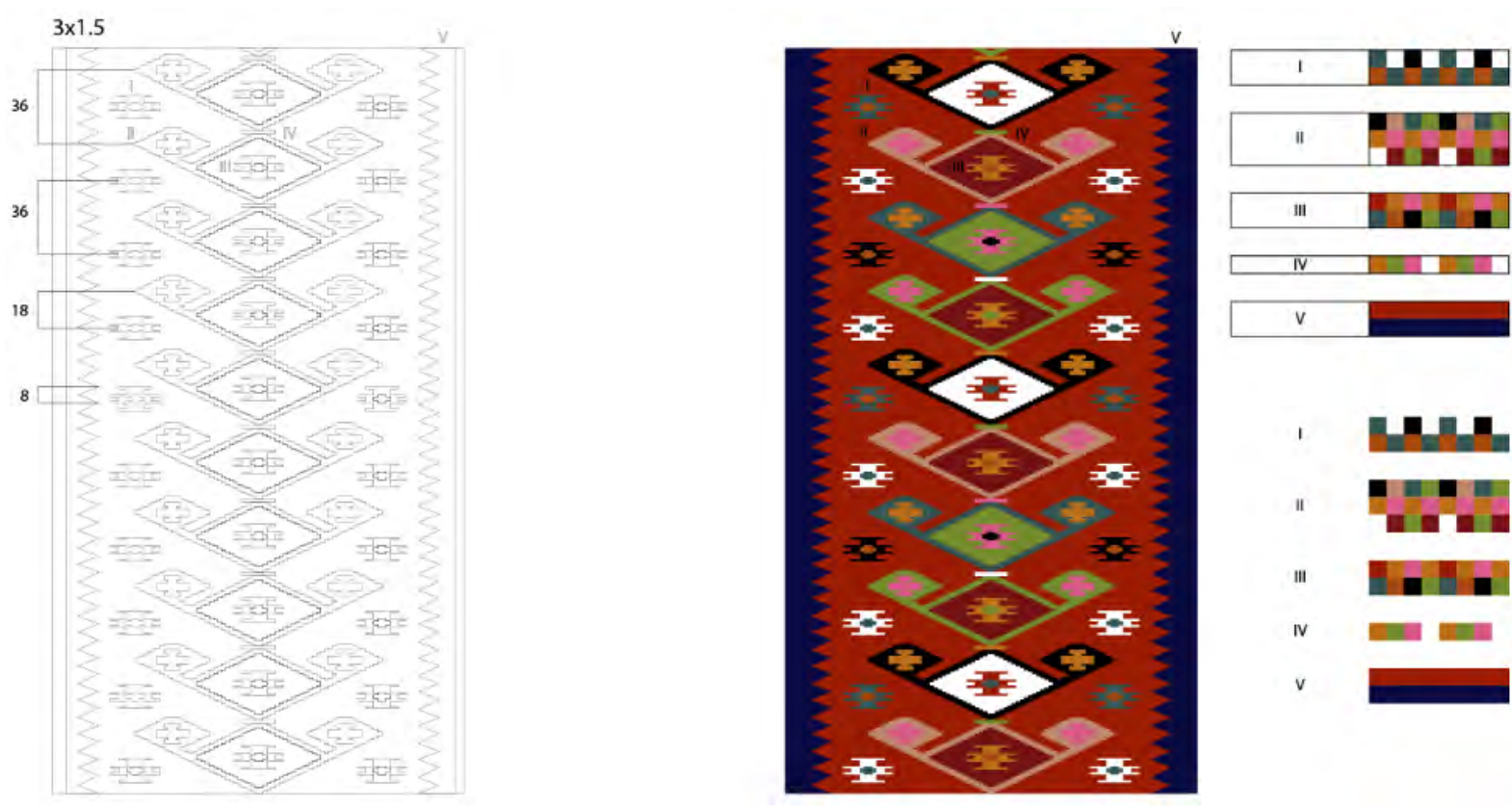

\section{Сл. 138. Детален преглед на ритамот и алтерациите на килимот}

Принципот на доминација кај ткаените килими се препознава во хиерархиската подреденост на елементите со различна визуелна тежина. Геометриските форми и нивните многубројни ритмични репетиции ја покриваат целата површина на килимите, а притоа, разликите во нивните големини и колоритот ги издвојуваат формите кои се во преден план, во однос на оние кои остануваат во заден план.

Фигурите и шарите кај презентираните килими се главно подредени по хоризонтална насока, поретко се присутни вертикални и дијагонални подредувања. Во сите три примери се забележува главно симетрична рамнотежа. Движењето како принцип се забележува преку ритмиката која го движи окото на набљудувачот и косите насоки на фигурите.

Во целокупниот дизајн на килимите е применета мрежеста композиција која овозможила правилен распоред на визуелните елементи, шарите, како и модуларност како основа на нивната пропорција. Кај нив не се забележува конкретна фокална точка ниту доминација на некој издвоен елемент. Единството во композицијата кај презентираните примери на ткаени килими е добено со повторувањето на елементите, шарите, а притоа нивните визуелни карактеристики не се натпреваруваат за внимание. 


\subsubsection{3. Дизајн принципи кај избраните грнчарски производи}

Примената на дизајн принципите кај грнчарските производи (сл. 139. а,6,в) може да се разгледува од аспект на производите како целина или на нивните декоративни елементи, шари. Кога се анализираат како целина, може да се заклучи дека станува збор за производи со ротациони форми, кои кај кои се забележува претежно симетрична радијална рамнотежа. Кога се гледаат како група сродни производи, поради нивната ротациона форма оставаат генерален впечаток на хармонија. Притоа може да се дискутира за пропорцијата на дијаметарот наспроти висината на производот. Пропорцијата на формата се разликува кај различните производи поради нивната функционалност. Некои имаат мал дијаметар наспроти висината (стомни, грниња), а други голем дијаметар наспроти висината (тави). Тоа зависи пред сѐ од нивната функционалност.

Кај вториот и третиот предмет $(1396, в)$ се забележува контраст во големината на целосната форма како композиција. Додека долниот дел е кружен и масивен, горниот е тенок и поддржан со тенки носачи, рачки.
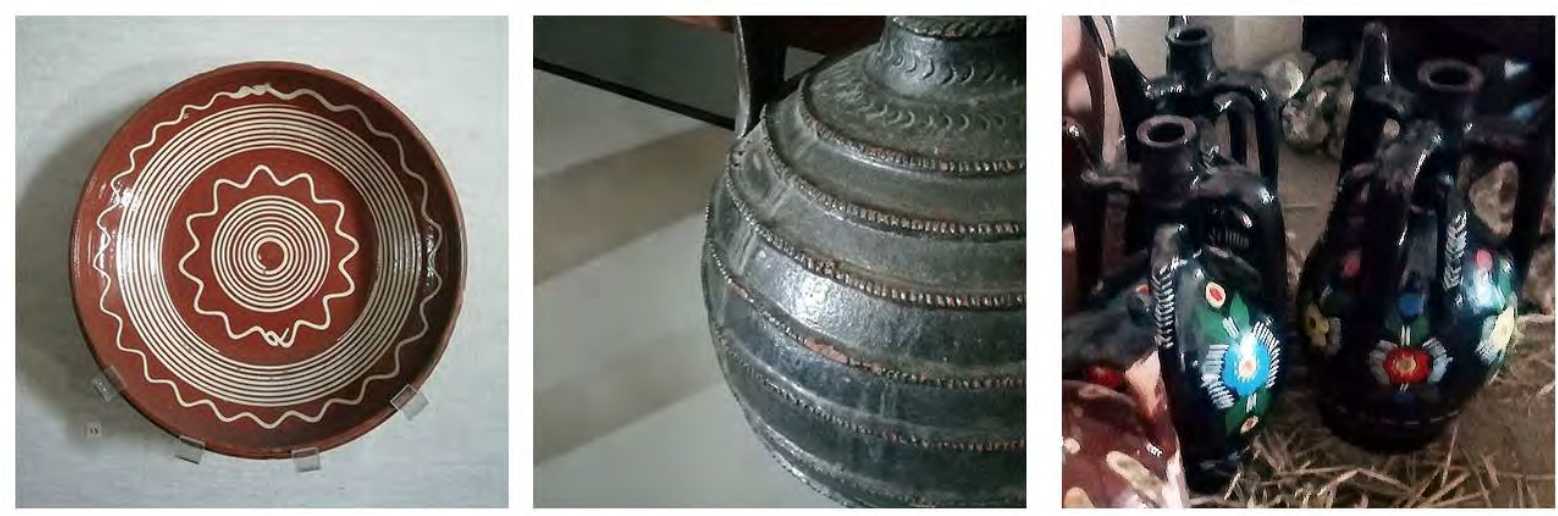

\section{Сл. 139. а, б, в Избрани грнчарски предмети}

Ако се анализираат декоративните елементи, шарите, најчесто применувана кај овие производи е шарата во вид на многубројни концентрични кругови околу центарот, каде ритмиката се добива со нивното повторување на одредено растојание, но се збогатува како алтернативен ритам со примена на синусоидни линии со кои се разделуваат групите концентрични кружници (сл. 139а). Притоа, фокална точка е празниот центар во средината на дното на тавата.

Кај шарите на грнчарските предмети се забележуваат два типа контраст. Во првиот пример, контрастот е формата наспроти позадината. т.е. бојата на позадината и белата линија врз неа. Кружниците во првите два примера го создаваат чувството на хармонија и добра пропорција во предметите.

Во вториот пример тенките испакнати обрачи создаваат ритам преку повторување со задржување исто вертикално растојание додека ја следат кривината на волуменот.

Формата на садовите е сама по себе едноставна, нејзината комплексност произлегува од повторувањето на елементите и аплицирањето на бои и помошни форми. Во последниот пример се препознават едноставни флорални форми изработени со ограничен број на линии, форми и бои. 


\subsubsection{4. Дизајн принципи кај избраните метални производи}

Избраните метални предмети (сл. 140 a,б,в) се предмети со различна намена, првите два со декоративна, а третиот со чисто функционална намена.

Аплицирањето на шарите кај металните предмети во вид на рељеф создава контраст на рапави и мазни површини, контраст на линии со различни дебелини и насоки. Во вториот пример (сл. 1396) овој контраст е многу поизразен поради поголемата длабочина на рељефот. Кај него пак се забележува дополнително алтернативен ритам со рамномерно повторување на група од линиски елементи со сложена геометрија.
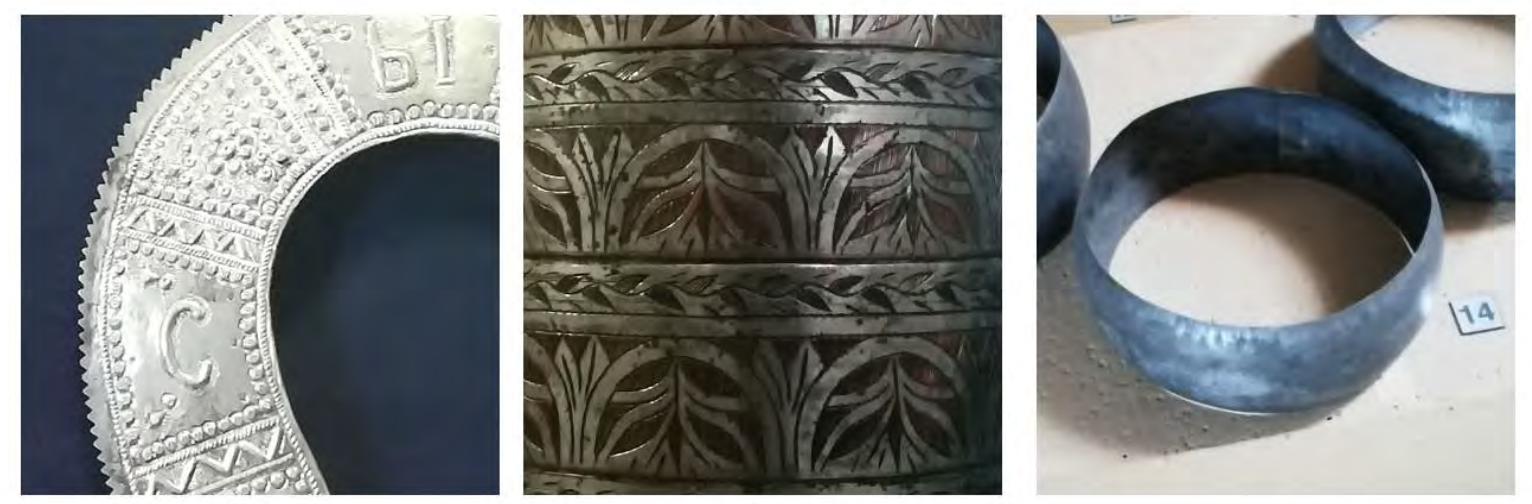

Сл. 140. а, б, в Избрани метални предмети

Во првиот пример (сл.140а) се забележува композиција која се развива континуирано по кружна линија. Хармонијата е постигната со доминантните геометриски форми постигнати со раздвижени линии и точки кои формираат геометриски форми. Контрасти се забележува во примената на линии наспроти точки и насоките на линиите (цик-цак наспроти прави). Ритамот е алтернативен, постигнат со повторување на цели блокови од исти сегменти, при што е применета радијалната рамнотежа. Единството е постигнато преку повторувањето и хармоничниот ефект поради визуелните ефекти на материјалот.

Едноставноста како принцип базиран на Гешталт принципот поедноставување, се забележува во примената на стилизацијата на декоративните флорални органски форми кај вториот пример (сл.1406). Применета е вертикална композиција со алтернативен ритам преку повторување повеќе хоризонтални редови од повторувачките стилизирани форми. Хармонијата е постигната со примената на органски форми и нивното повторување води кон постигнување единство на целокупниот дизајн.

Третиот пример има исклучиво фунционална намена и не може да се дискутира премногу за неговите естетски квалитети (сл.140в).

\subsubsection{5. Дизајн принципи кај избраните дрвени производи}

Избраните дрвени предмети (сл. 141. а-в) се предмети со чисто функционална намена и затоа и кај нив не може да се дискутира премногу за нивните естетски квалитети. Може да се заклучи дека е применет минималистичкиот пристап, кој соодветствува на принципот „формата ја следи функцијата“. Генерално, се забележува хармонија која потекнува, пред сѐ, од бојата на материјалот и текстурата која зависи од него. Кај трпезарискиот прибор и масата, 
континуираната линија што ги дефинира слободните органски форми на сите парчиња од оваа композиција, создава чувство на хармонија (сл. 141а).
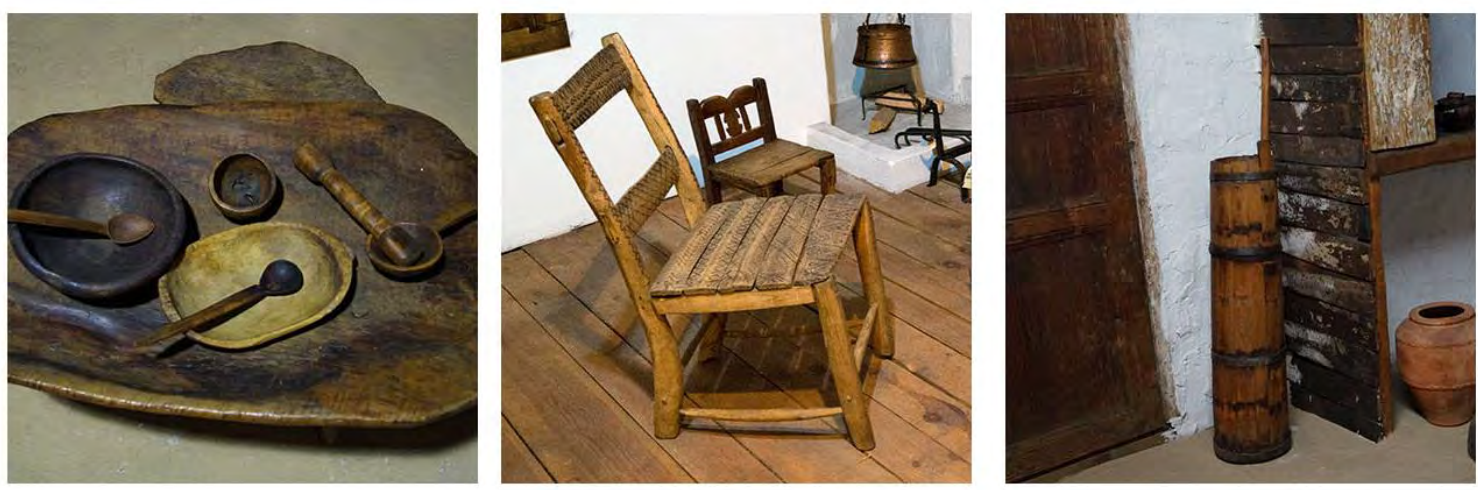

Сл. 141. а, б, в Избрани дрвени предмети

Столиците (сл. 1416) се со ергономски дизајн, што се забележува во висината на седиштето и наклонот на наслонот за грб, неопходни за поголема удобност при седењето. Од аспект на принципите на естетиката, столицата има вертикална композиција со симетрична рамнотежа, контраст на насоките (хоризонтална наспроти вертикална) и хармонија во формата (геометриски форми на сите делови), бојата, материјалот и текстурата.

Кај дрвените предмети, како бучимот (сл. 141в) и слични на него по својата конструкција и форма (каци, качиња, бочви), се забележува ротациона форма со изразена радијална симетрија и рамнотежа. 


\section{6. Систематизација на резултатите од анализата}

Во претходното поглавје беше извршено идентификување и опис на дизајнерските елементи и принципи кај избраните примероци од неколку категории предмети, кои припаѓаат на македонското културно наследство. Следниот чекор беше систематизација на резултатите од анализата, поточно на извлечените податоци, со цел да се препознаат и дефинираат клучни елементи и правила, карактеристични за естетиката на македонските традиционални предмети од секојдневниот живот. Крајна цел е да се даде преглед на визуелните елементи и карактеристики на естетиката во вид на обележја на културниот идентитет, кои ќе бидат инспирација при дизајнот на производи преку кои ќе биде препознатлив токму македонскиот идентитет.

Во ова поглавје е извршено сублимирање на заклучоците од анализирањето на визуелните елементи и принципи како транслативните членови, со цел да се понудат можни алтерации преку: промена на материјал, промена на функција или промена на форма. На тој начин ќе бидат понудени како можност за развој на нови карактеристики на производи со македонски визуелни идентитет, па дури и трендови, преку глокализација и создавање нови производи со нивно понатамошно следење.

Најпрво извршена е систематизација на сите податоци во врска со поединечните дизајнерски елементи кај избраните пет категории традиционални предмети и нивно презентирање во табели, заради подобра визуелна прегледност (табела 3 - табела 7). Во следниот чекор, крајните резултати од анализата на сите нив се презентирани во т.н. морфолошка матрица, позната алатка во инженерството и дизајнот за систематизиран преглед на извлечените градбени единки од петте категории, презентирани во вид на колони, каде редовите ги претставуваат извлечените дизајн елементи (табела 8). Крајната цел на оваа морфолошка матрица е да на прегледен визулен начин да се овозможи комбинирање на градбените единки од различните категории. На пример, форма од текстилните производи, текстура од грнчарски производи, материјал од металните производи. На тој начин можностите за комбинирање добиваат огромен дијапазон.

Овој пристап со примена на алатката морфолошка матрица овозможува понатамошна примена како инспирација во сите области на визуелно обликување (индустриски дизајн, графички дизајн, веб дизајн итн.).

Категориите носии и килими имаат доста сличности во визуелните карактеристики кои произлегуваат од обликувањето во две димензии. Анализата на овие две категории предмети е сведена на проучување на карактеристиките на шарите, кои имаат доста меѓусебни сличности. Во креирањето на композициите голема улога играат и применетите бои, текстури, пропорции, насоки, големини. Со нивно комбинирање овозможена е богата ритмика и динамичност.

Категориите грнчарски, метални и дрвени производи се сродни поради нивната тридимензионалност. Кај сите нив се забележуваат карактеристики во тридимензионалното обликување на предметот како целина (примарно обликување), но истовремено вредни за анализа се и декоративните елементи (секундарно обликување), материјалот и текстурата. 
Табела 3 - Извлечени дизајн елементи на носиите

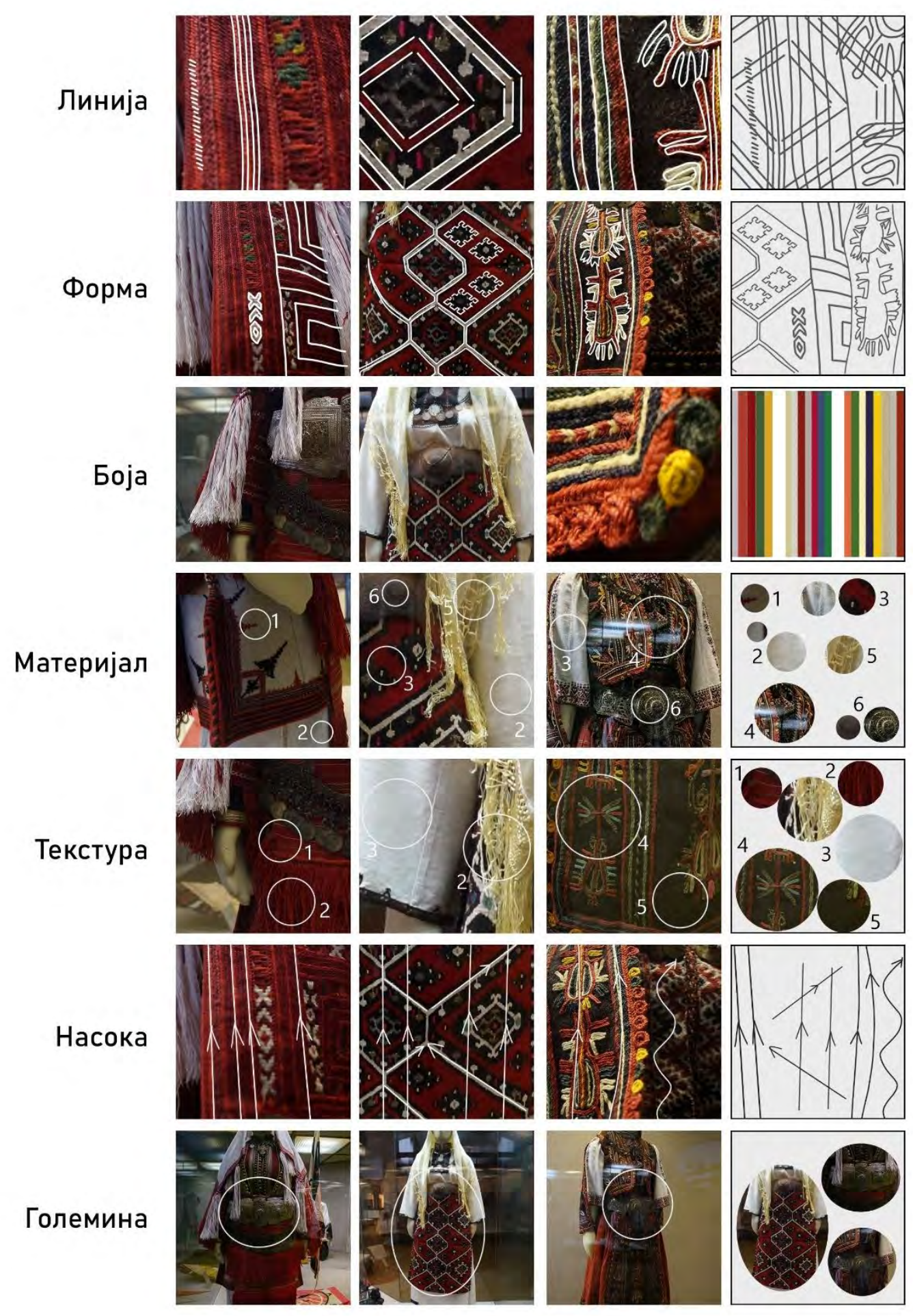


Табела 4 - Извлечени дизајн елементи на текстилните предмети

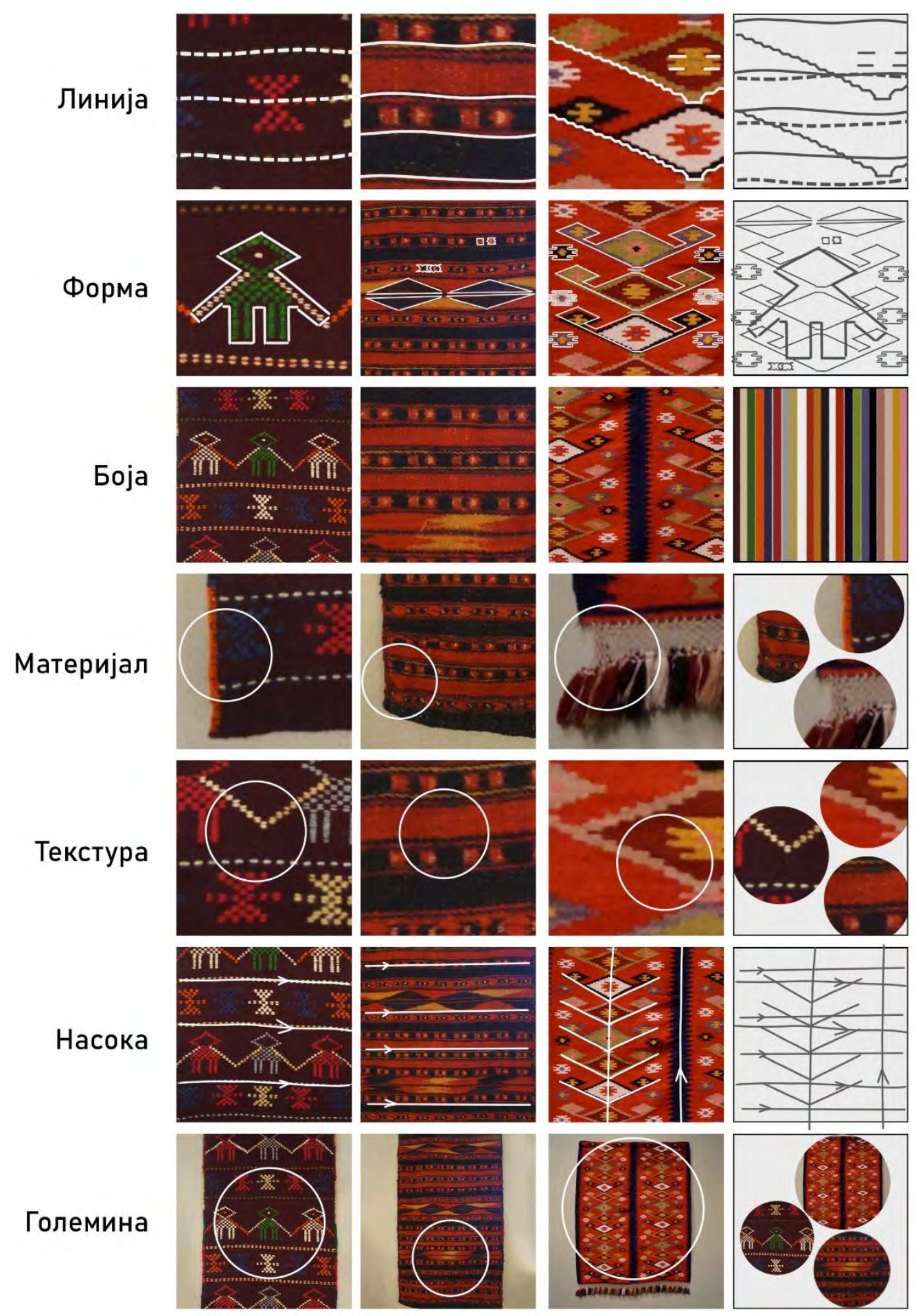


Табела 5 - Извлечени дизајн елементи на грнчарските производи

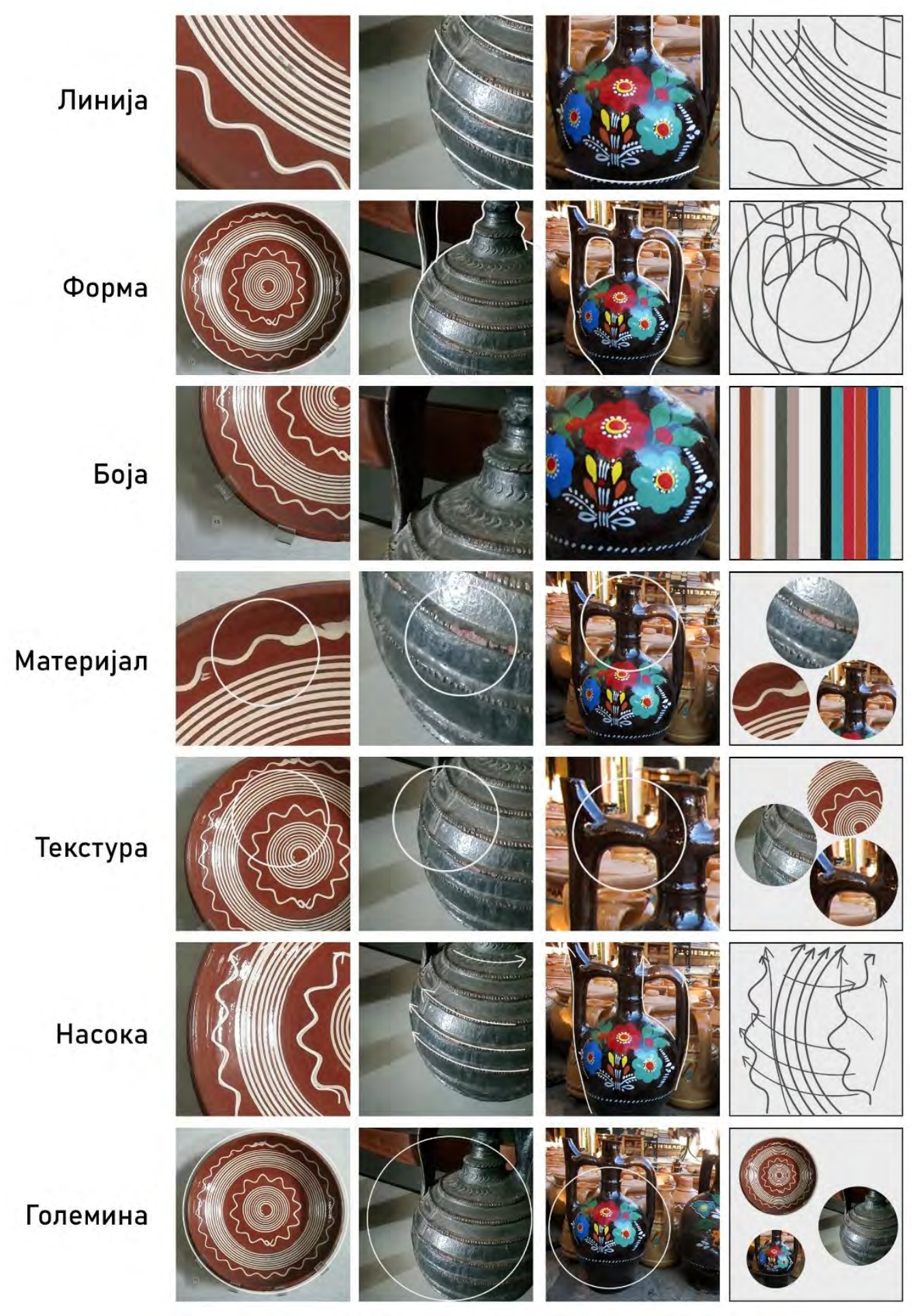


Табела 6 - Извлечени дизајн елементи на металните производи

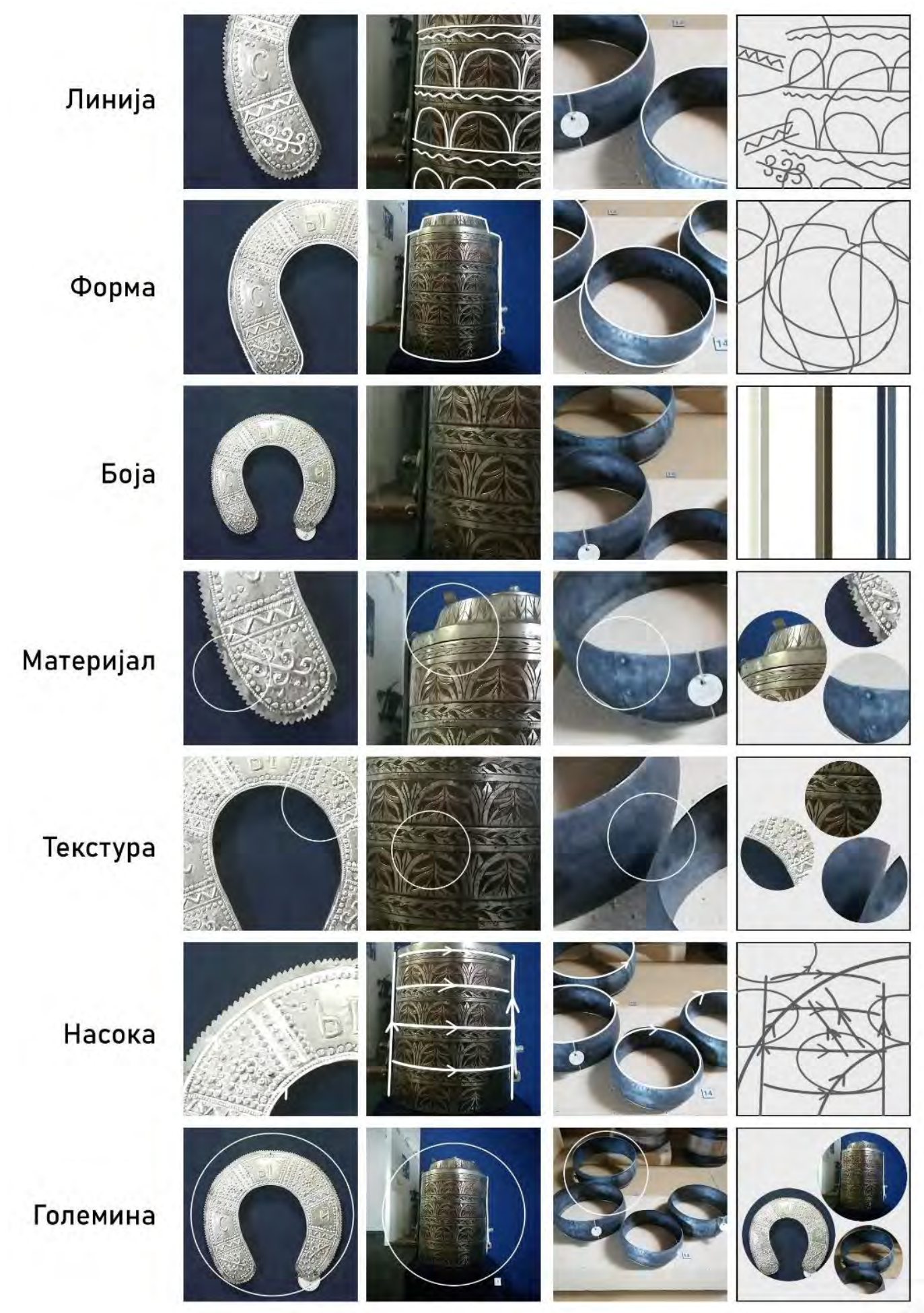


Табела 7-Извлечени дизајн елементи на дрвените производи

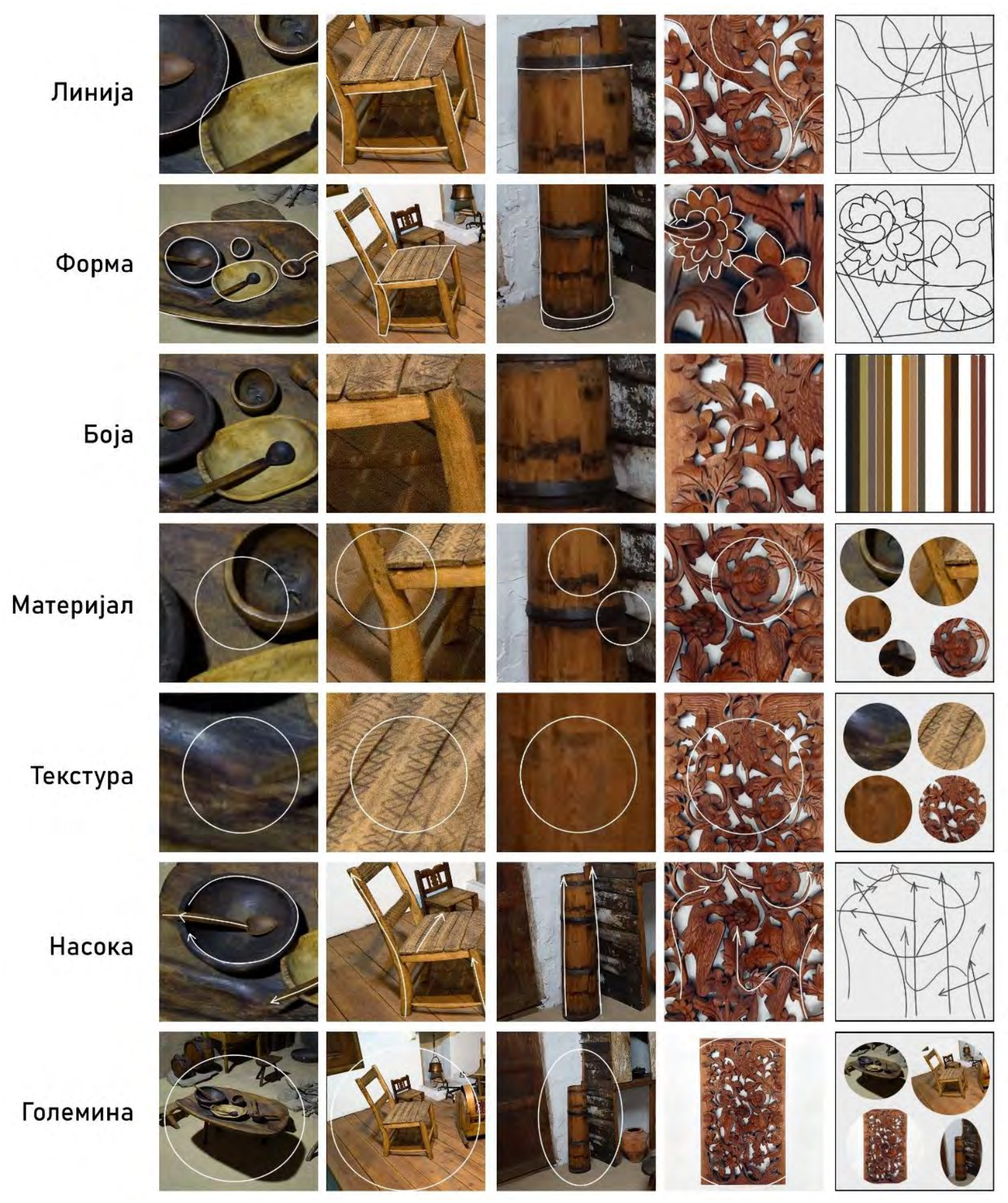


Табела 8- Морфолошка матрица со извлечени дизајн елементи од анализата на производи

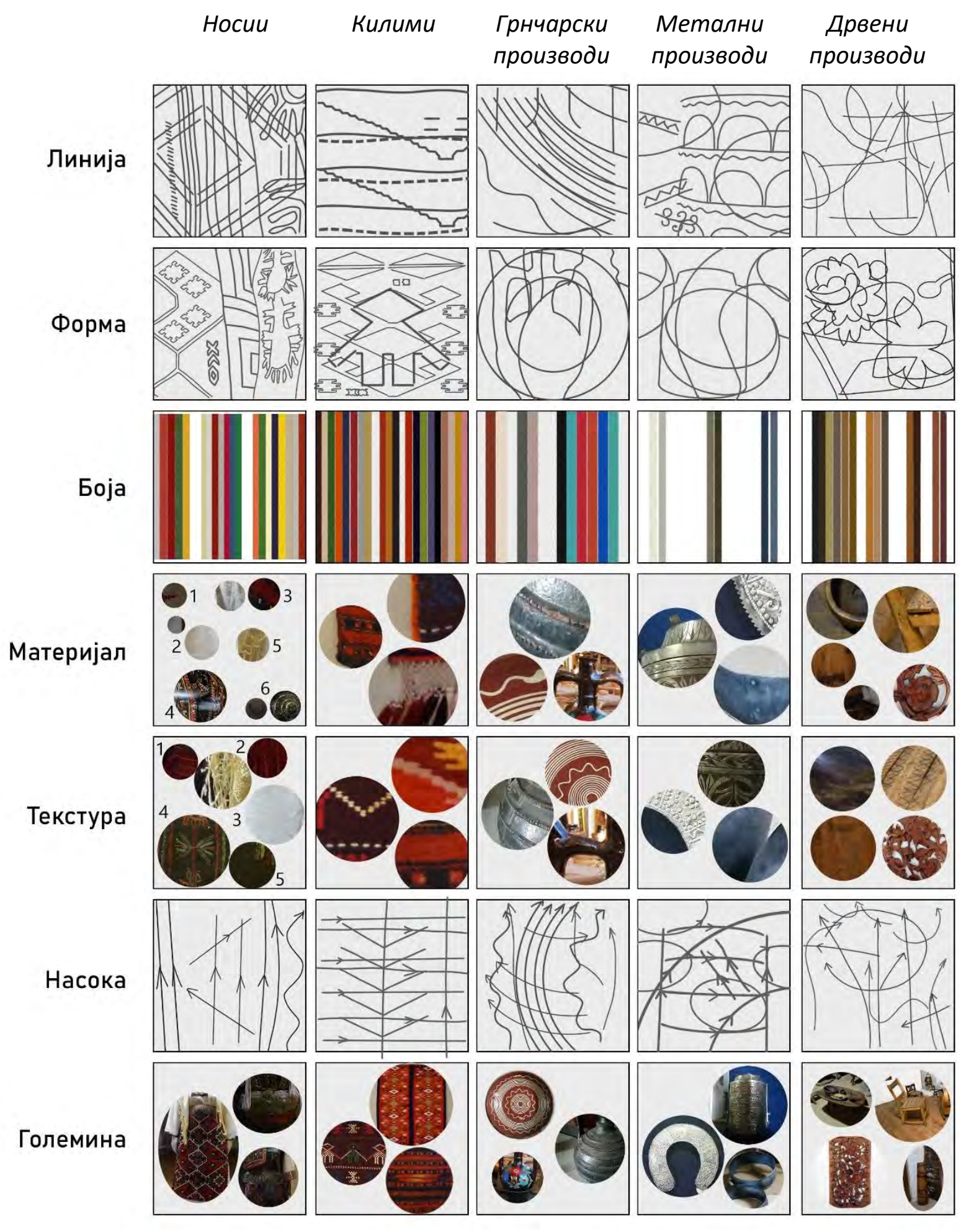




\section{1. Геометриска анализа на 2Д градбените елементи извлечени од дизајнот}

на традиционалните текстилни предмети

Во категоријата традиционални текстилни производи спаѓaат носиите и килимите. Тие нудат голема палета на карактеристични линии и форми со кои се обликувани препознатливи шари, честопати како симплификација на форми од природата. Со геометриска анализа на испитаните урнеци извлечена е група на карактеристични форми со соодветна геометрија и пропорција, како и карактеристични бои. Tие се обработени со примена на софтвер за 2Д визуелизцаија со цел да бидат понудени како 2Д визуелни градбени елементи со цел да бидат применливи како инспирација во обликување на производи, графички дизајн, веб дизајн итн. (табела 9).

Табела 9 - Карактеристични визуелни градбени елементи извлечени од македонските традиционални текстилни производи
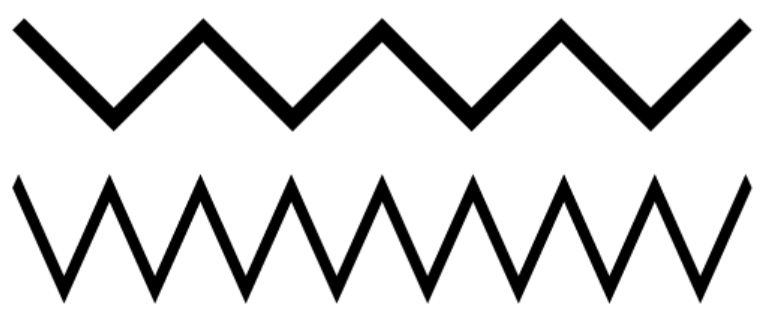

Линија
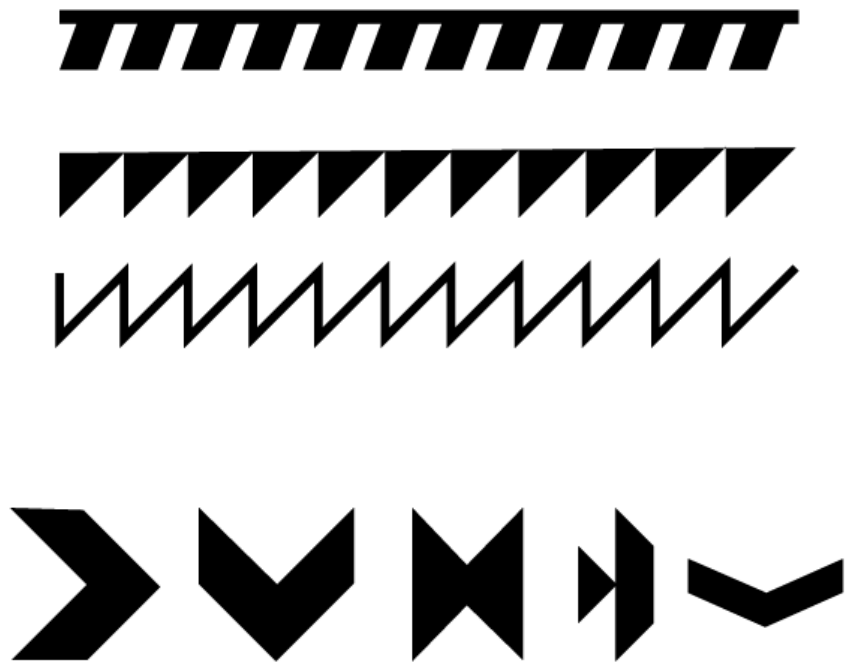

Едноставни

форми
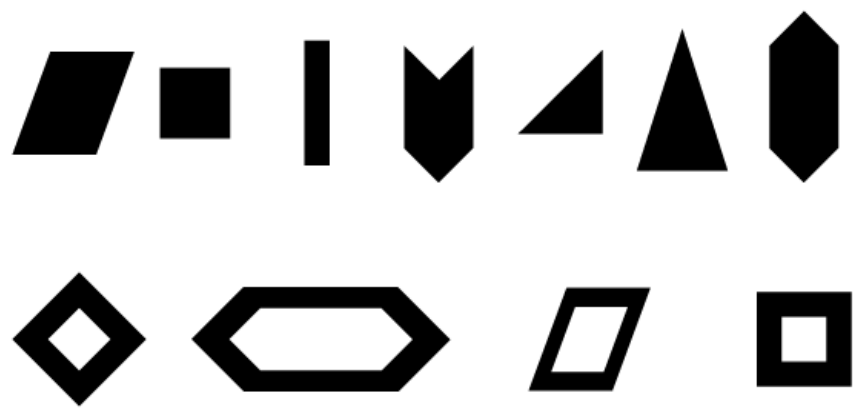


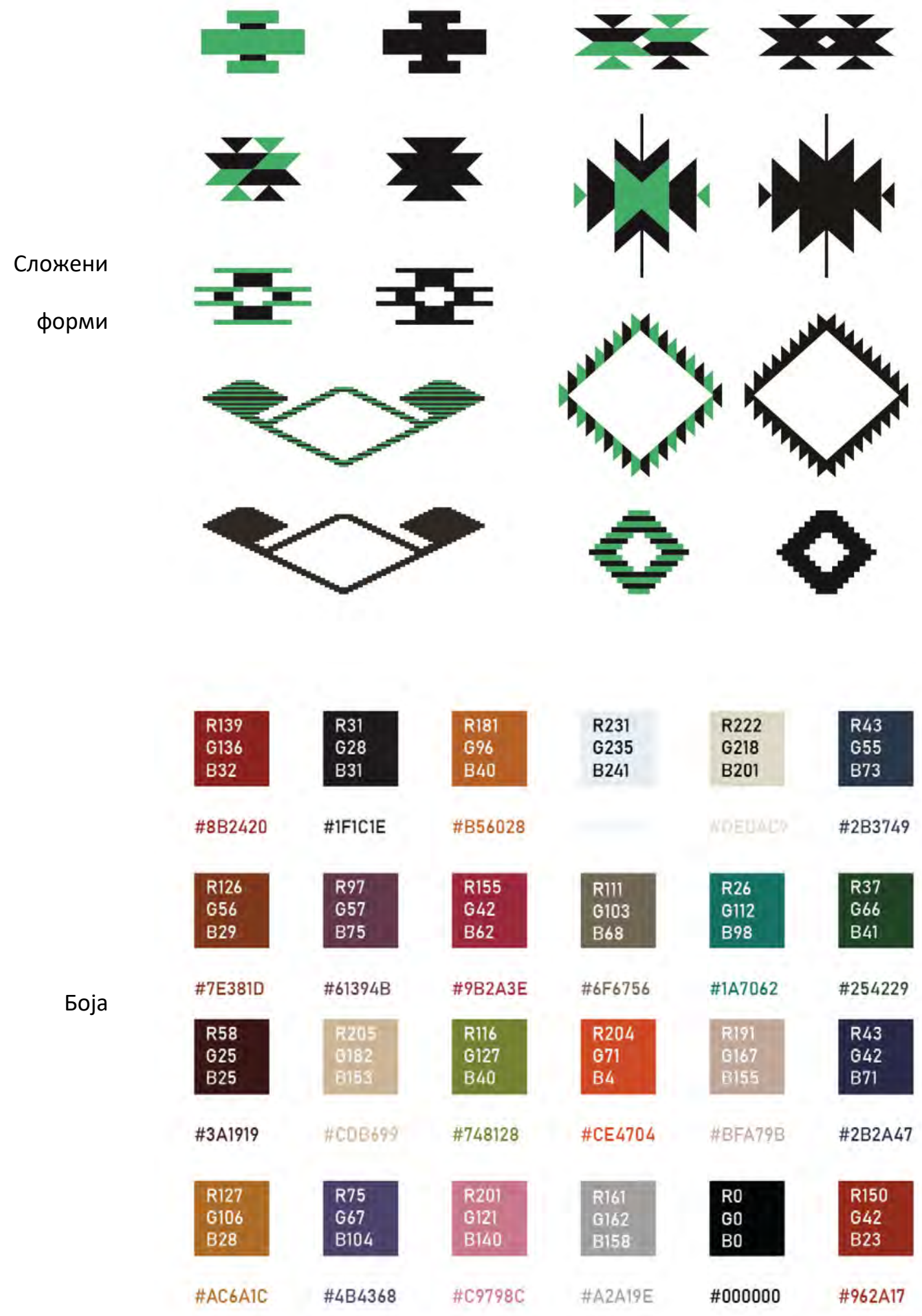




\section{2. Геометриска анализа на градбените принципи извлечени од дизајнот на традиционалните текстилни предмети}

2Д градбените елементи забележани кај текстилните традиционални производи се применувани во различни комбинации, најчесто преку повторување во праволиниски низи формирајќи богати композиции. Извршена е геометриска разработка на композициите од шари кај два килими: „Сеџаде“ и „Караказлија“ (сл. 142 и 143).
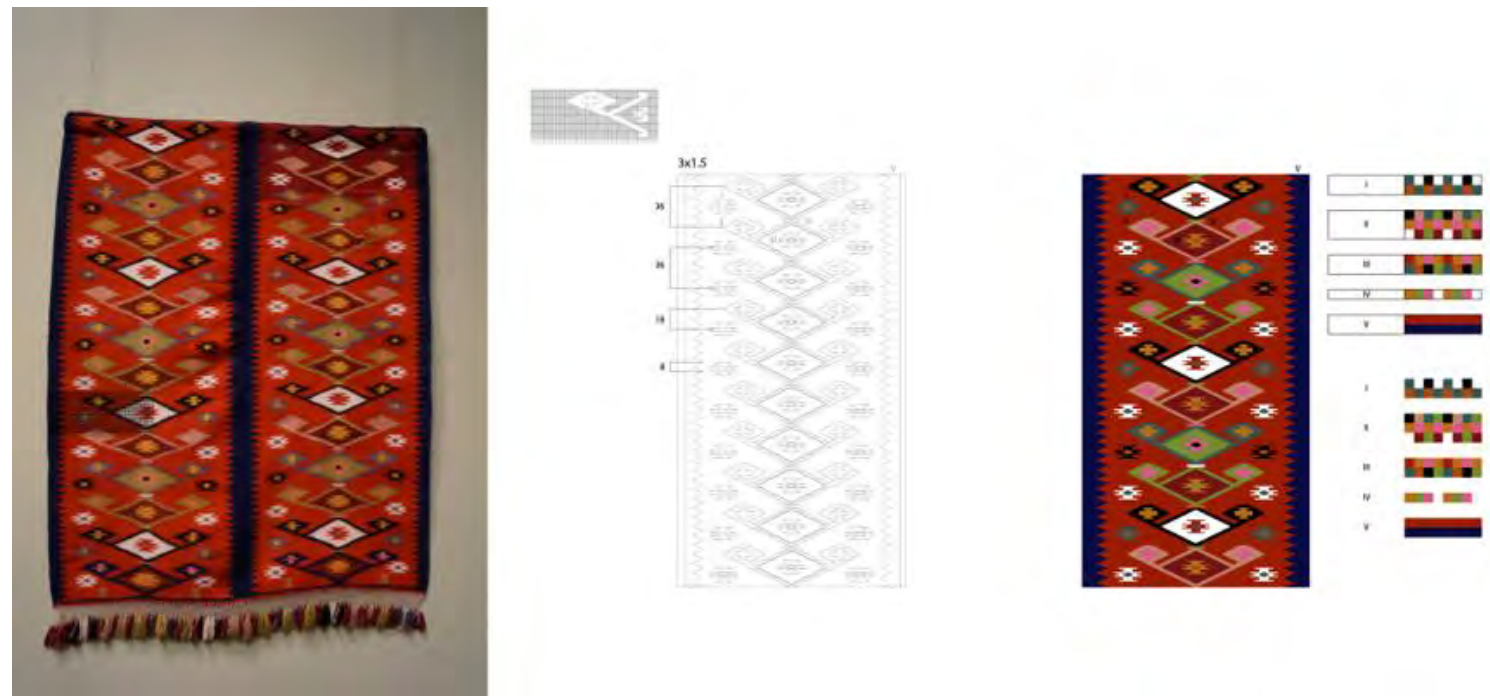

Сл.142. Извлечени визуелни карактеристики на килим 1 „Сецаде“
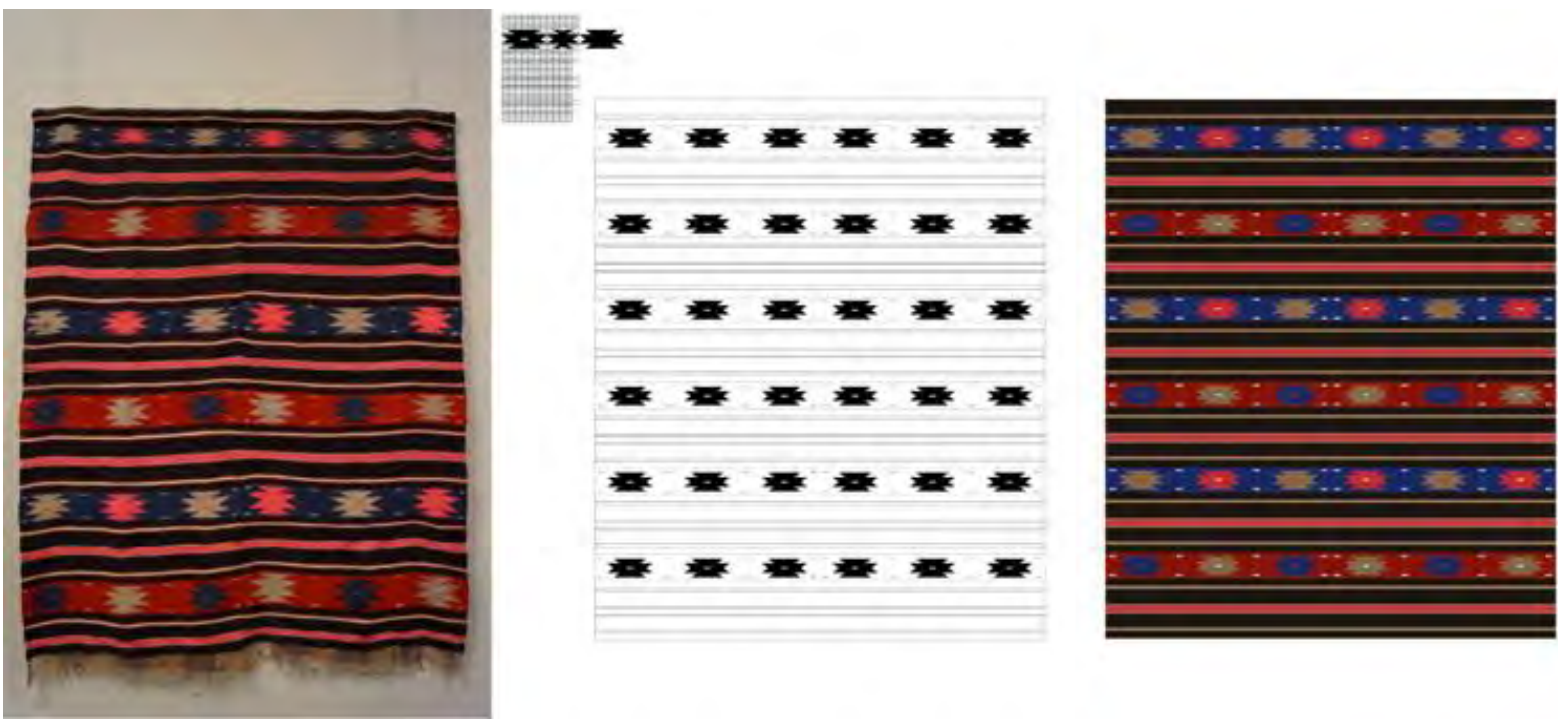

Сл. 143. Извлечени визуелни карактеристики на килим 2 „Караказлија“

Се забележува сложена ритмика, претежно алтернативен ритам и богатата раздвиженост, динамика, обезбедена со примена на дијагонални насоки кои се вкрстуваат меѓусебно. Мрежестата композиција обезбедува правилно следење и обезбедување на ритмичноста на елементите. Резултатите од оваа анализа се презентирани во табела 10. 

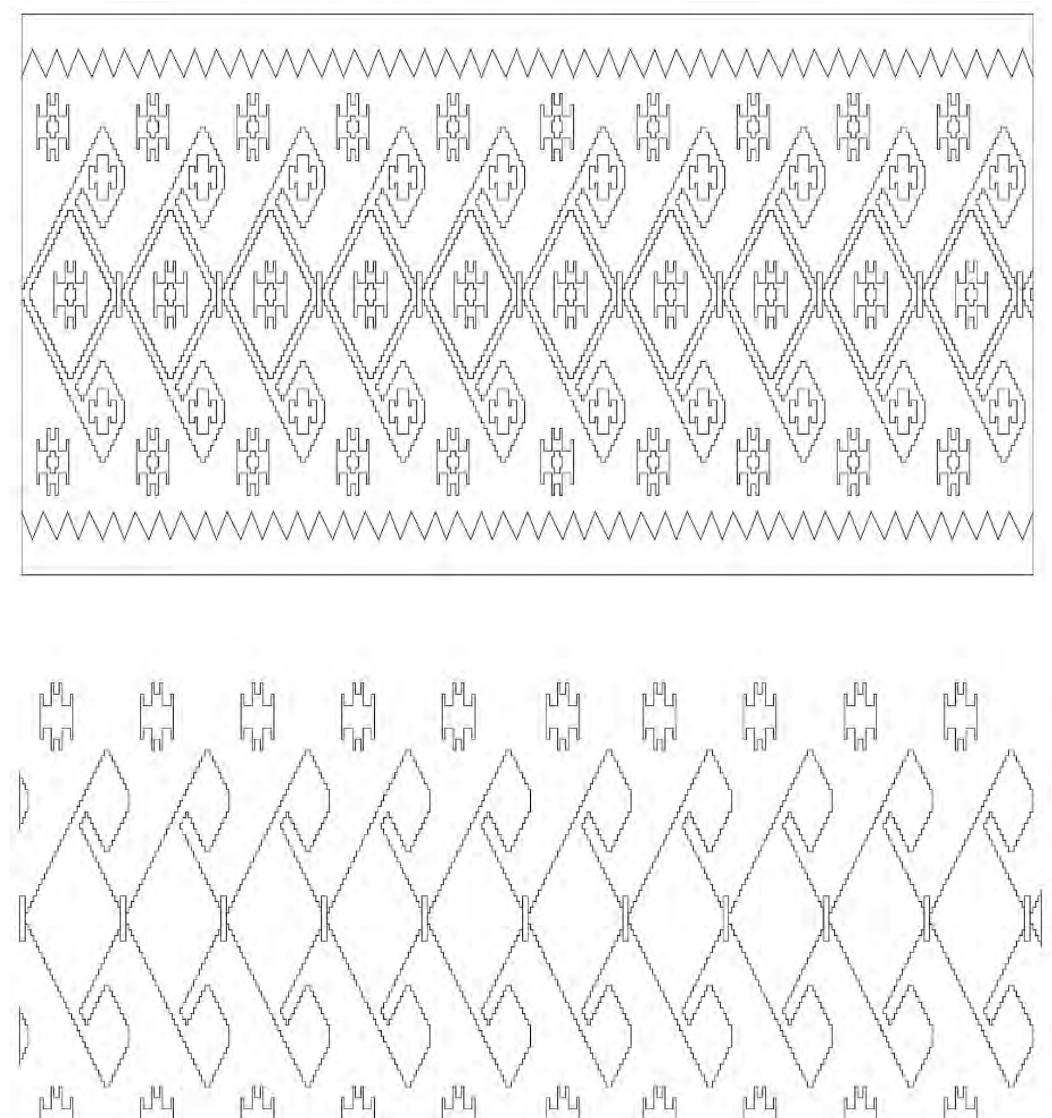

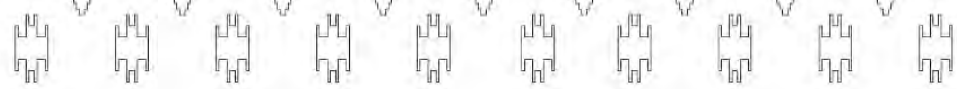

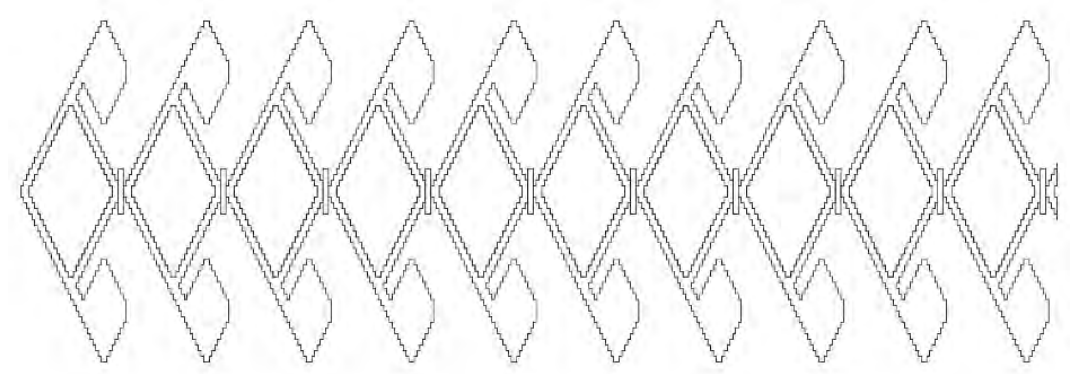

WWWWWWWWWWWWWWWWWWWW

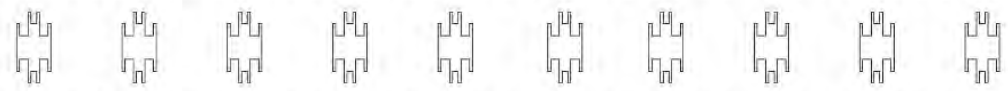
WWWWWWWWWWWWWWWWWWWW

然 
Во продолжение презентирани се дополнителни примери со комбинации на извлечените карактеристични градбени елементи и принципи и нивните бескрајни можности, кои несомнено биле применувани и од безимените дизајнери од нашето минато (сл. 146 -148) .

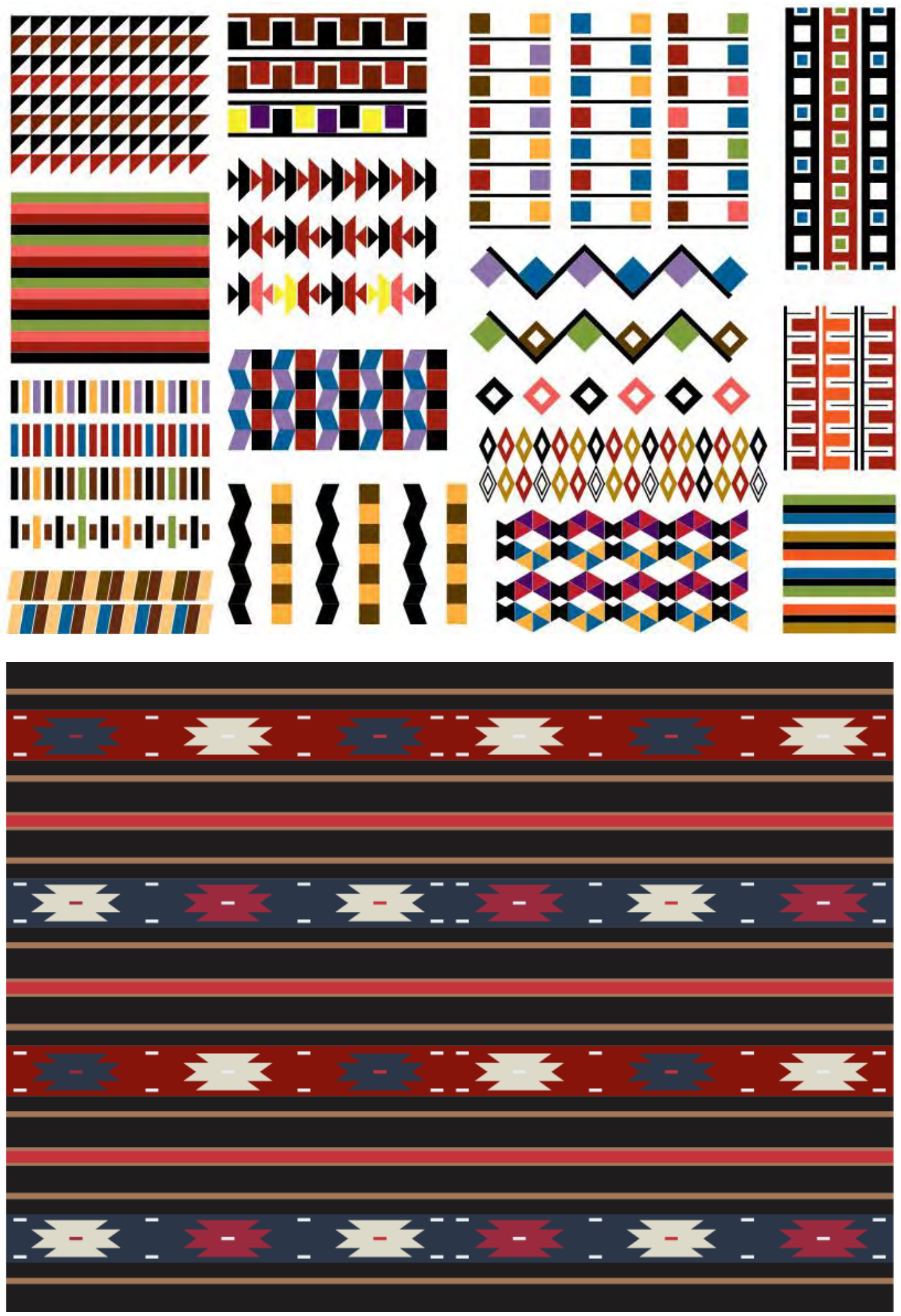

Сл. 144. и 145. Композиции креирани со извлечените карактеристични градбени елементи и принципи според примерите од македонските традиционални текстилни производи 

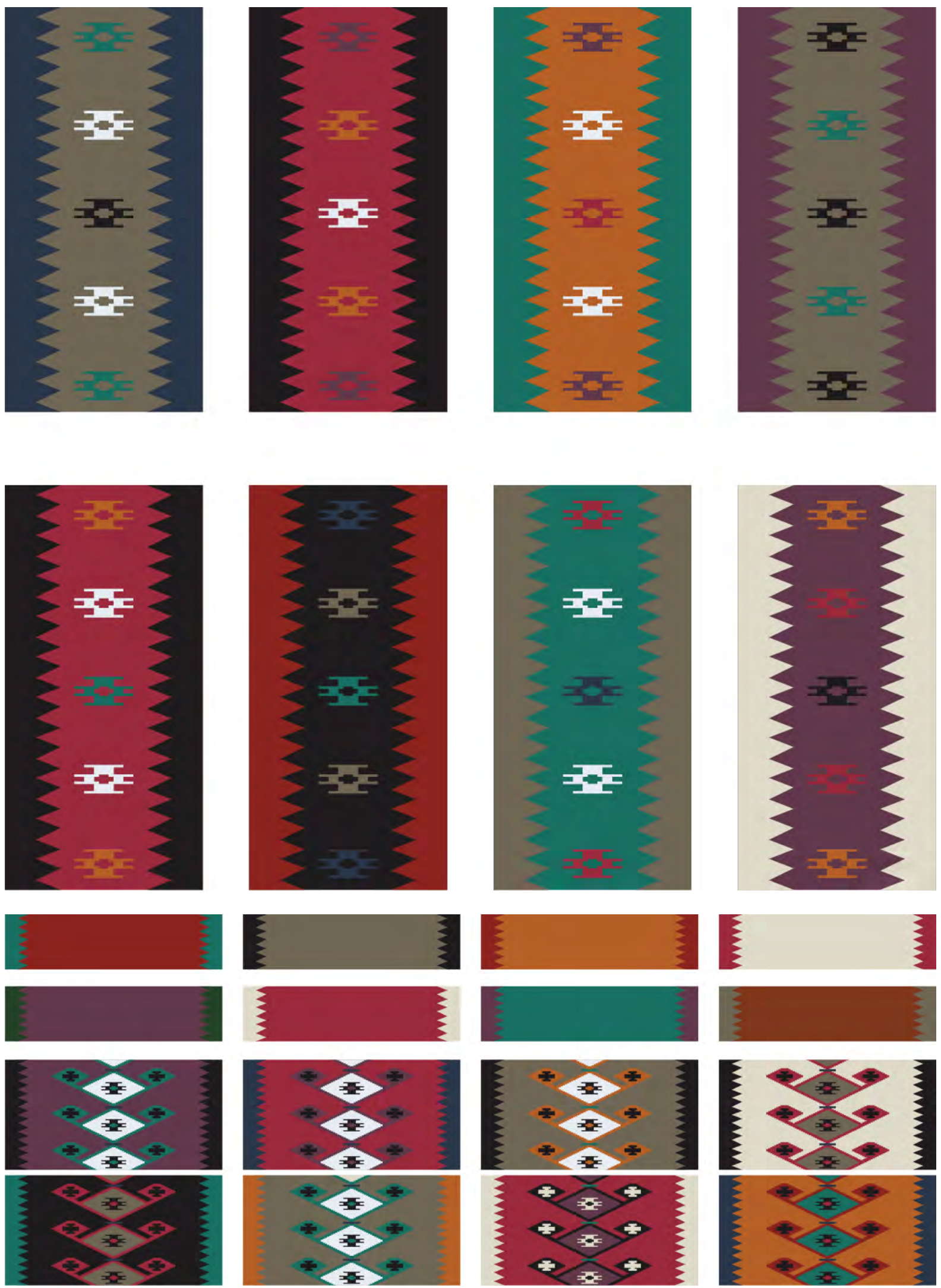

Сл. 146. Композиции креирани со извлечените карактеристични градбени елементи и принципи според примерите од македонските традиционални текстилни производи 


\section{7. Примена на резултатите од истражувањето во дизајн на производи}

Во ова поглавје се презентирани неколку примери на дизајнирани производи од различни области на дизајнот инспирирани од визуелните елементи на македоските традиционални производи. Нивното обликување е потпомогнато со примена на понудените алатки за инспирација презентирани во претходното поглавје, во вид на морфолошка матрица со градбените елементи од петте категории традиционални предмети (табела 8), како и табелите со векторизирани примери на линии и 2Д форми (табела 9) и композиции (табела 10). Резултат се производи со современ дизајн, но препознатлив по визуелните карактеристики на македонските традиционални производи.

Табела 11 - примена на морфолошка матрица за избор на градбени елементи во нов дизајн

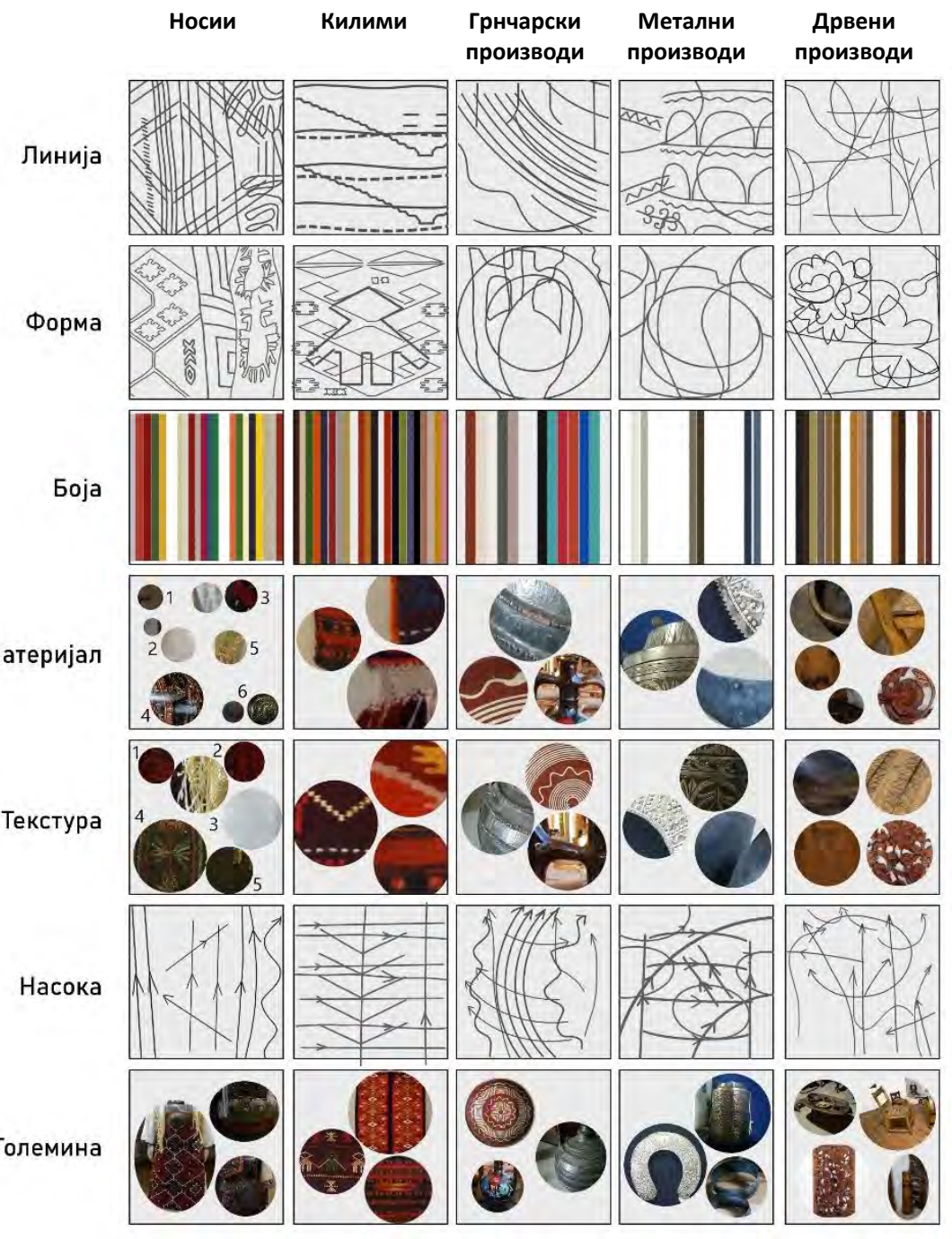




\section{Пример 1: Систем од компонибилни модули од боено дрво}

Применета е морфолошката матрица од табела 8 од која се извлечени градбените елементи за обликувањето на модуларен систем оформен од неколку компатибилни форми, со примена на дрво како материјал од категоријата дрвени производи, бои од категоријата килими и текстура од категоријата грнчарски производи (сл. 149 - 151). Модуларниот систем овозможува да биде применет во различни големини и ориентација и со различна намена, од украсни кутии за накит, висечки или стоечки ормарчиња итн.
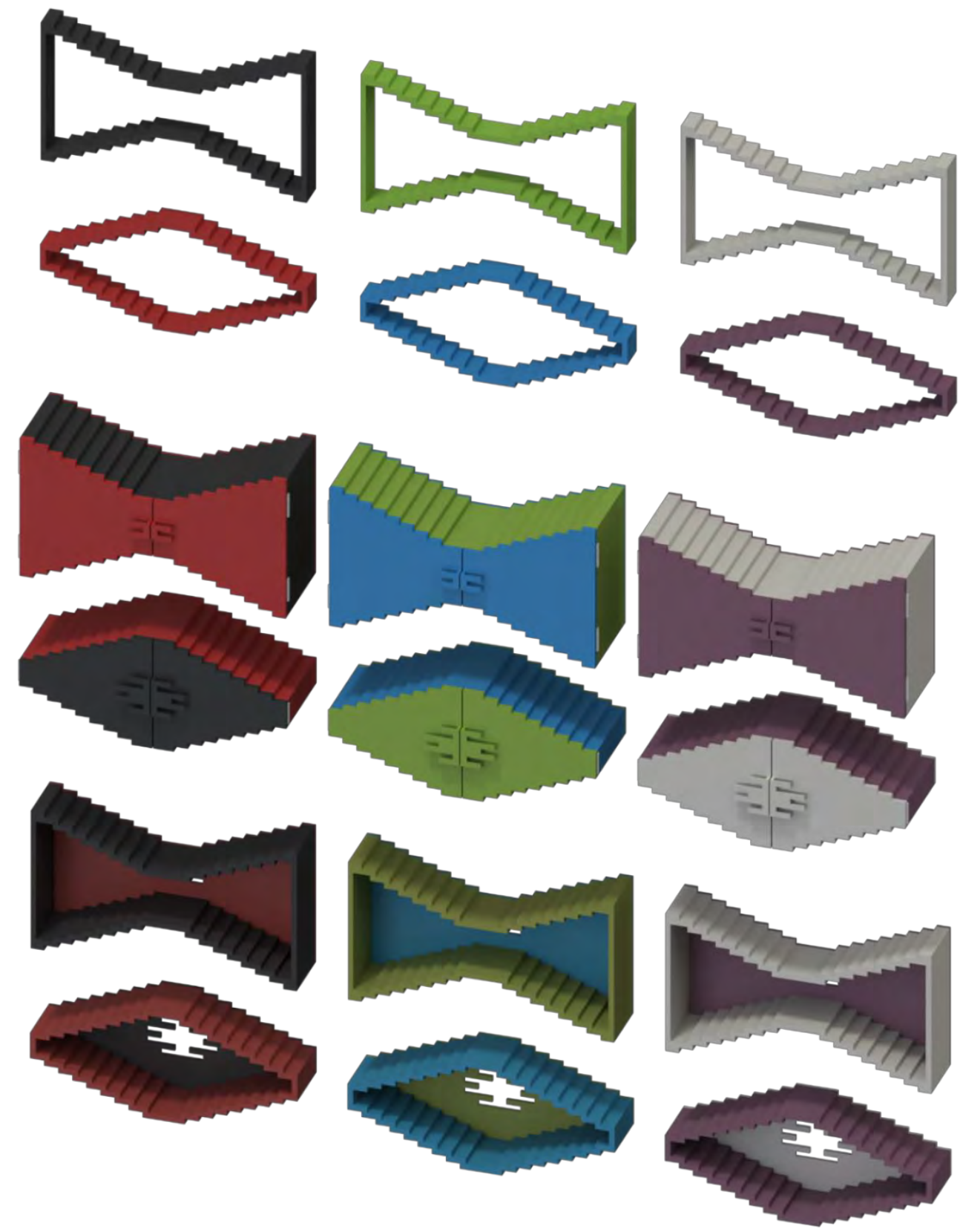

Сл. 147. Систем од компонибилни модули од боено дрво - кутии за складирање ситни предмети 

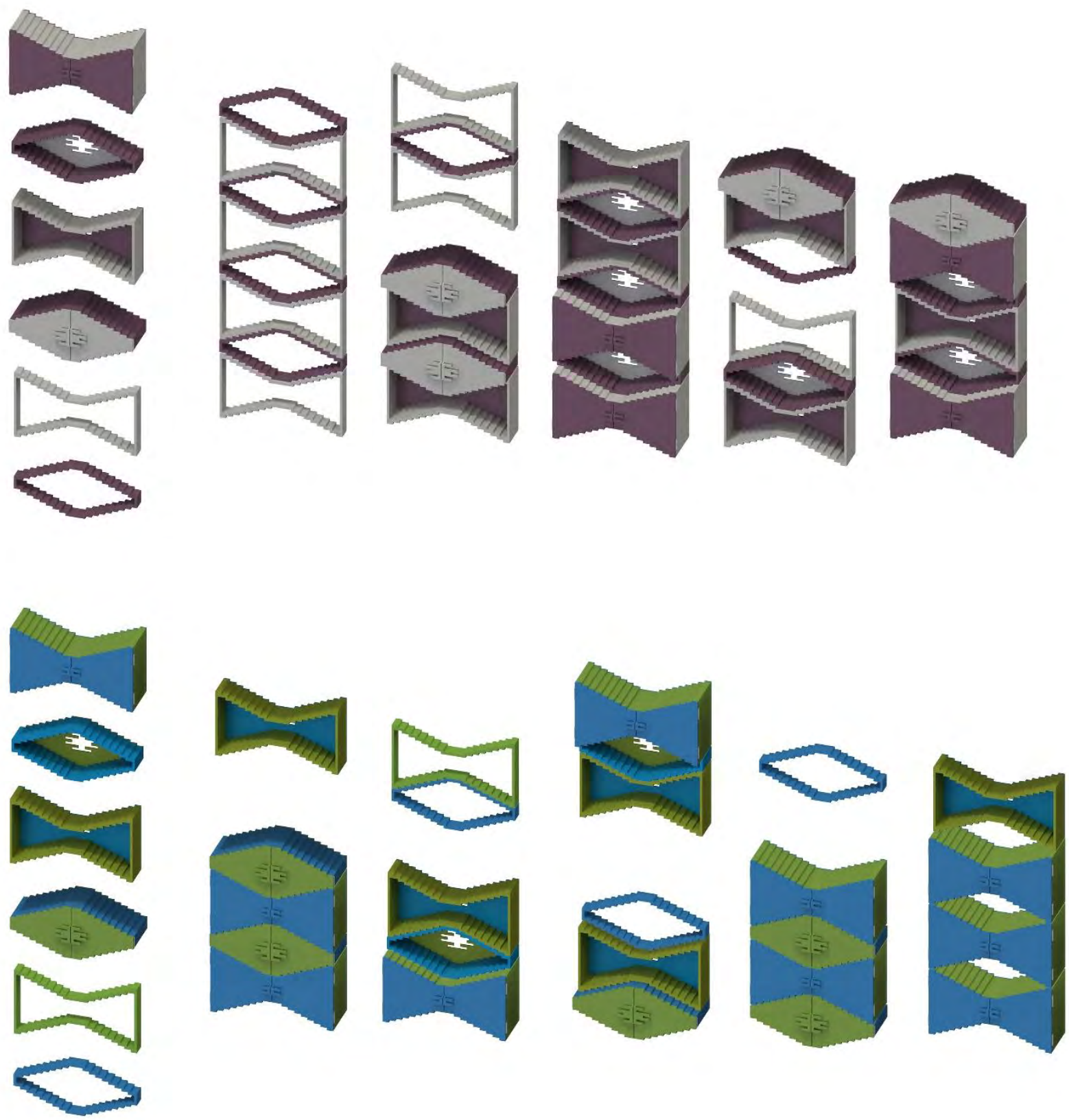

Сл. 148. и 149. Систем од компонибилни модули од боено дрво - подни и висечки елементи 

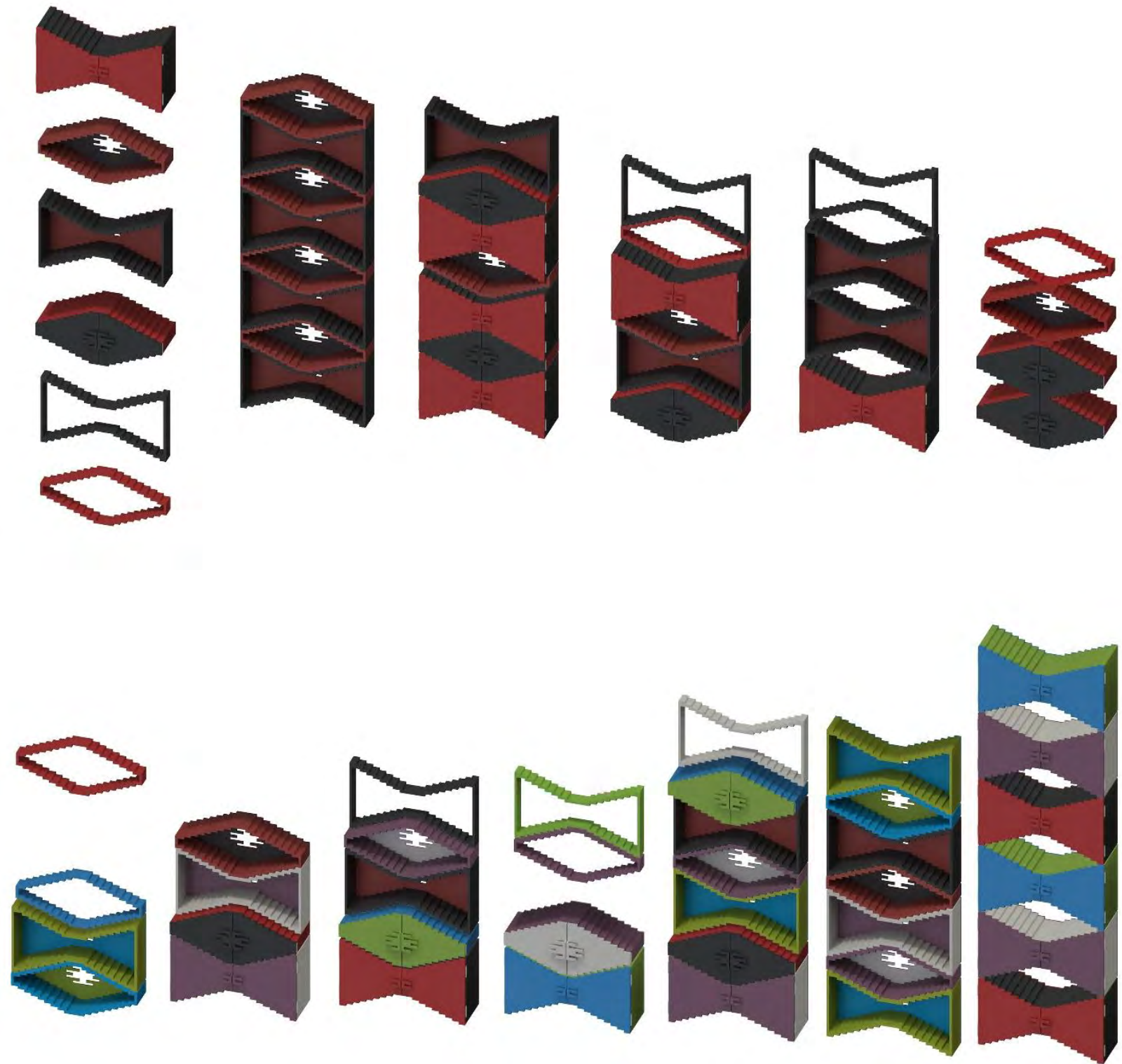

Сл. 150. и 151. Систем од компонибилни модули од боено дрво - подни и висечки елементи 
Пример 2: Систем од компонибилен мебел од дрво
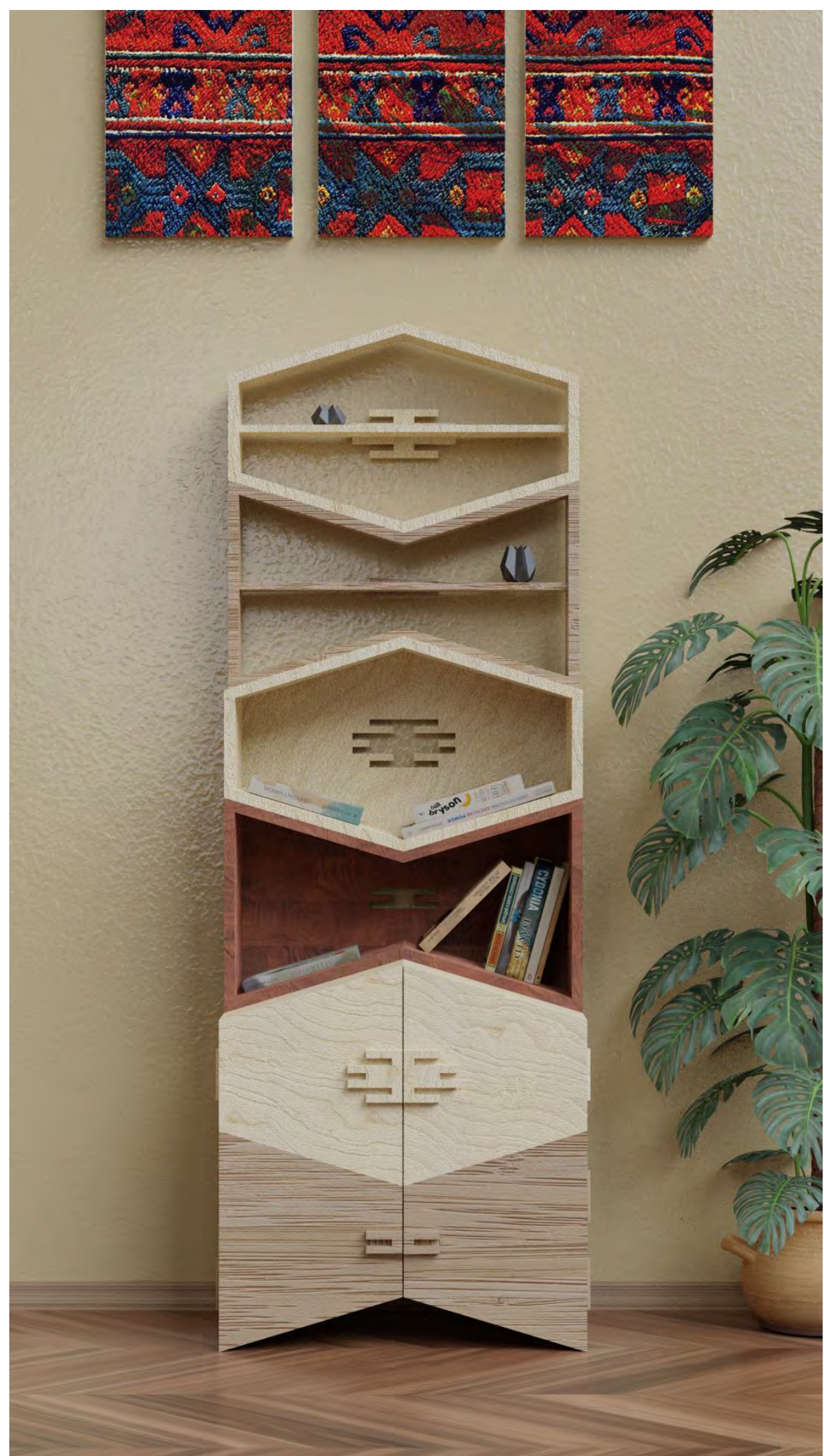

Сл. 152. Компонибилен мебел од дрво - варијанта 1 


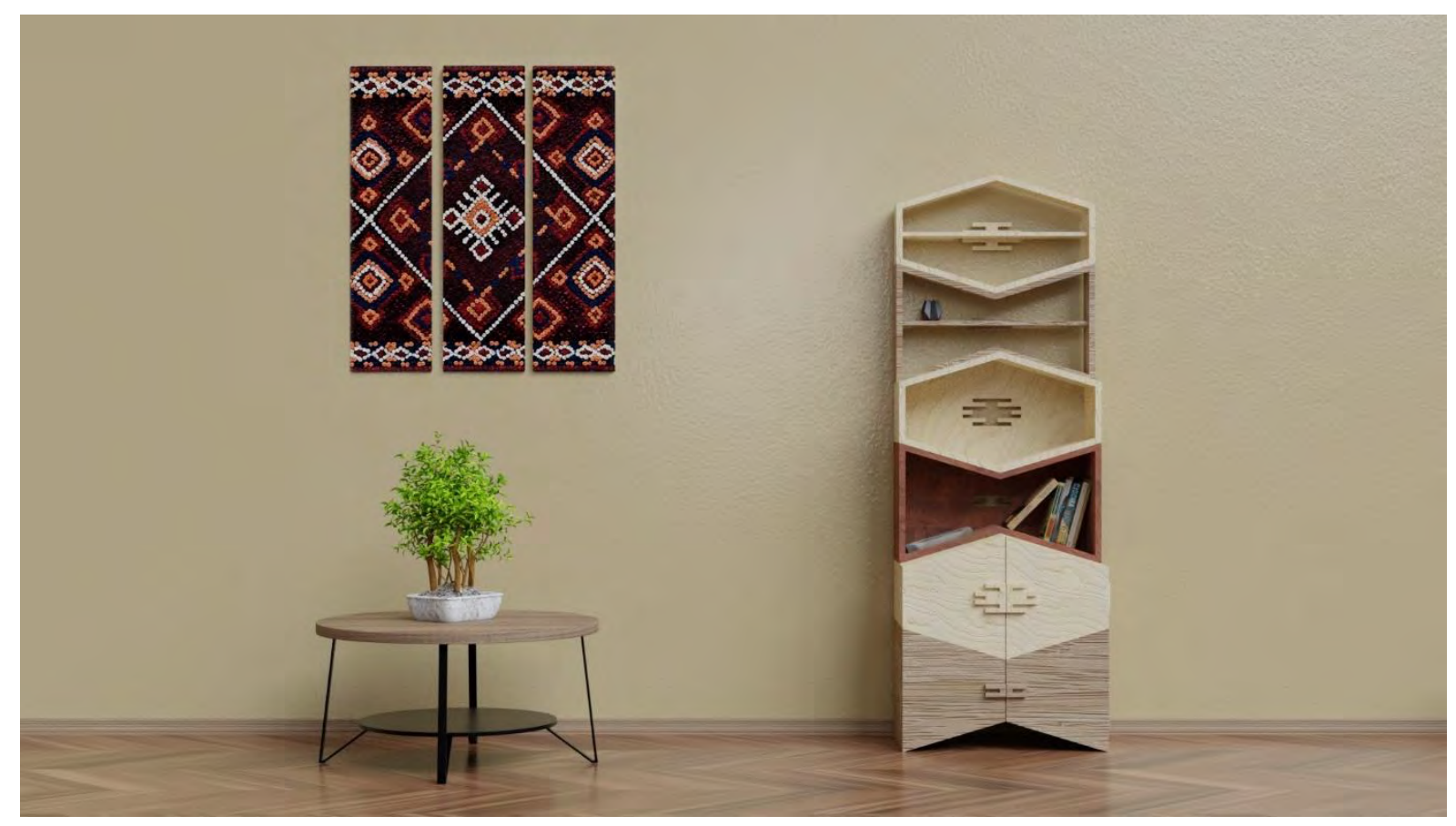

Сл. 153. Компонибилен мебел од дрво - варијанта 2
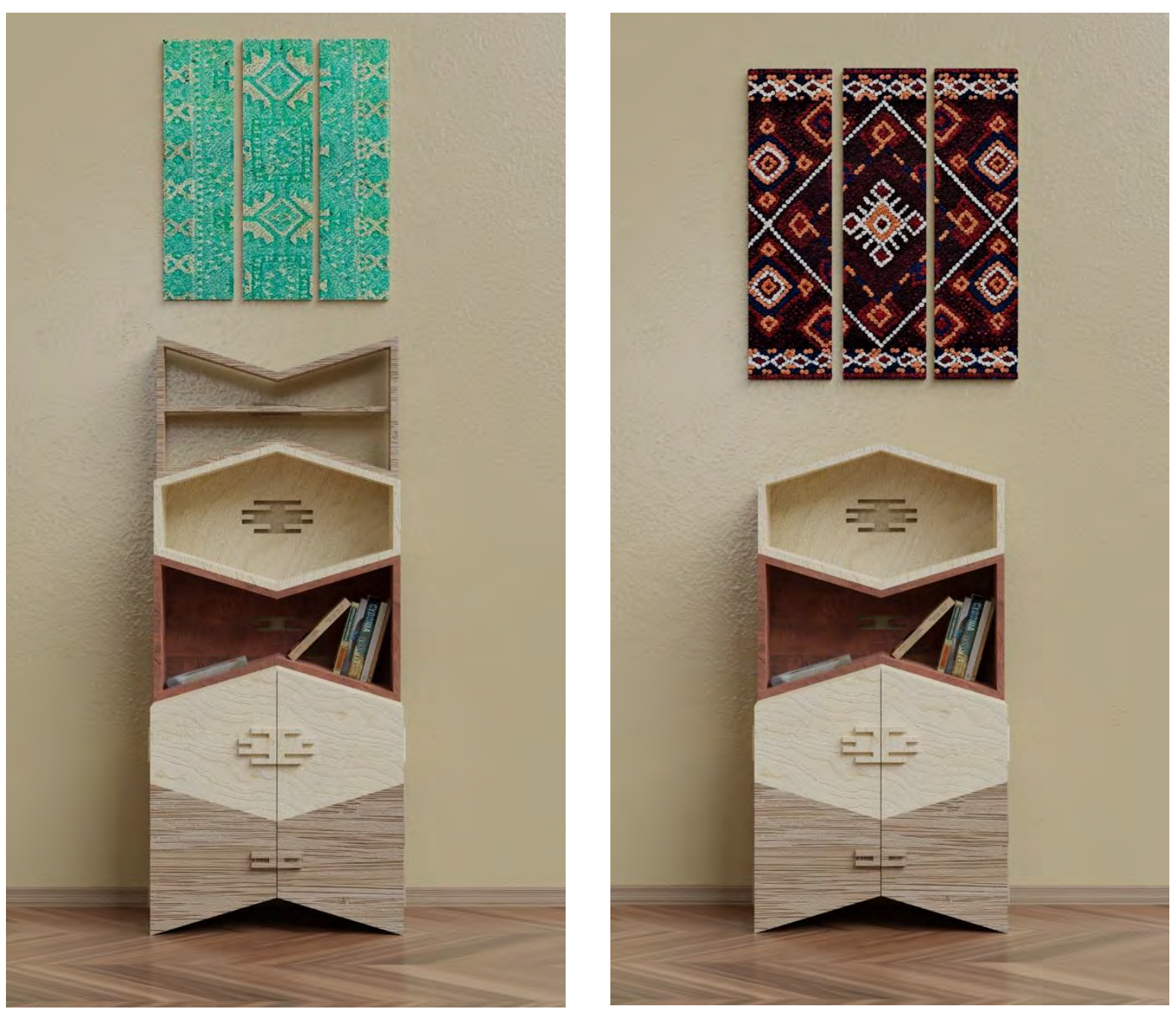

Сл. 154. и 155. Компонибилен мебел од дрво - варијанта 3 и 4 
Пример 3 - текстилни производи со шари инспирирани од македонските визуелни карактеристики (перници, завеси, прекривки за маса итн.)

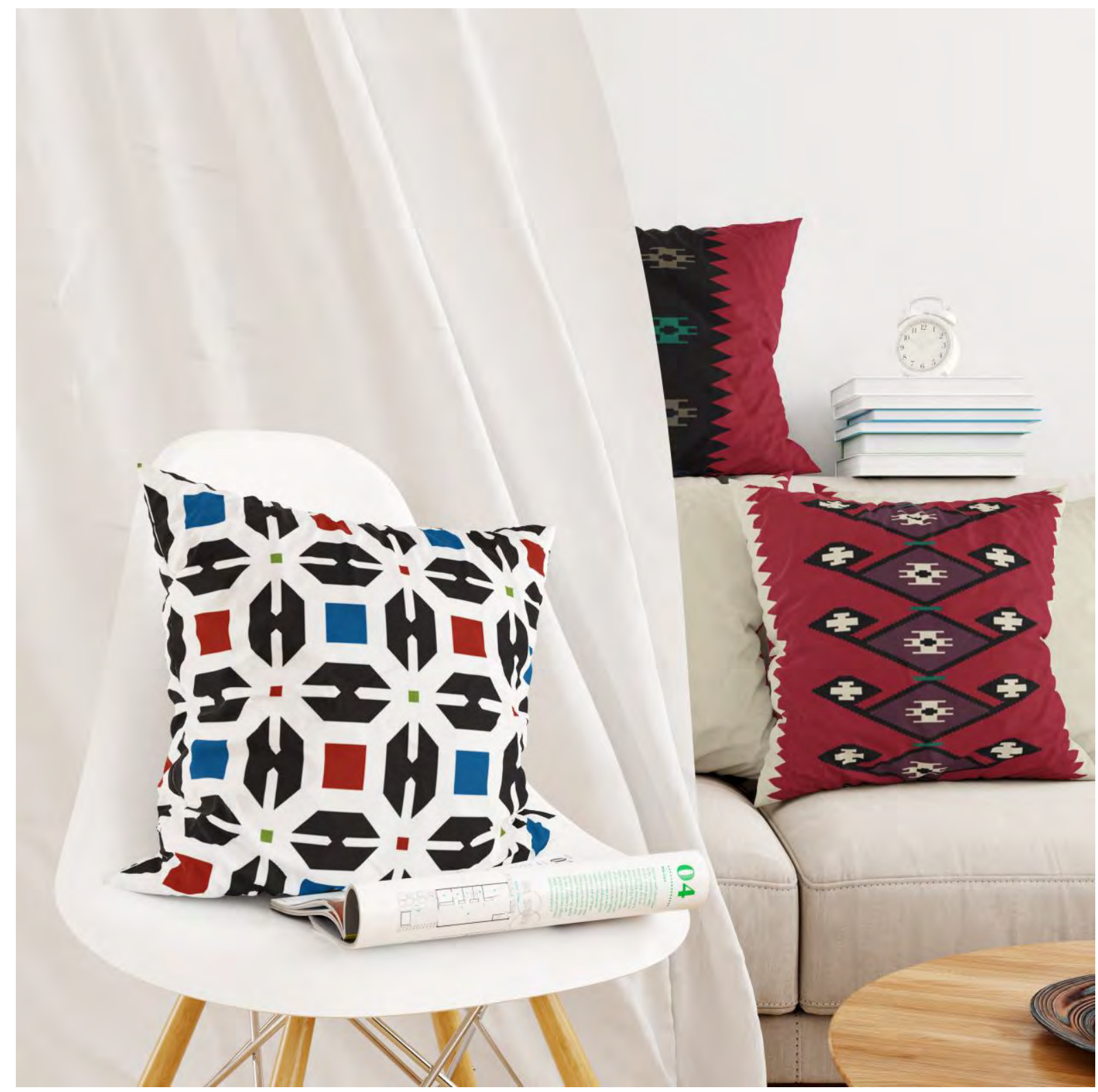

Сл. 156. Текстилни производи - варијанта 1 и 2 


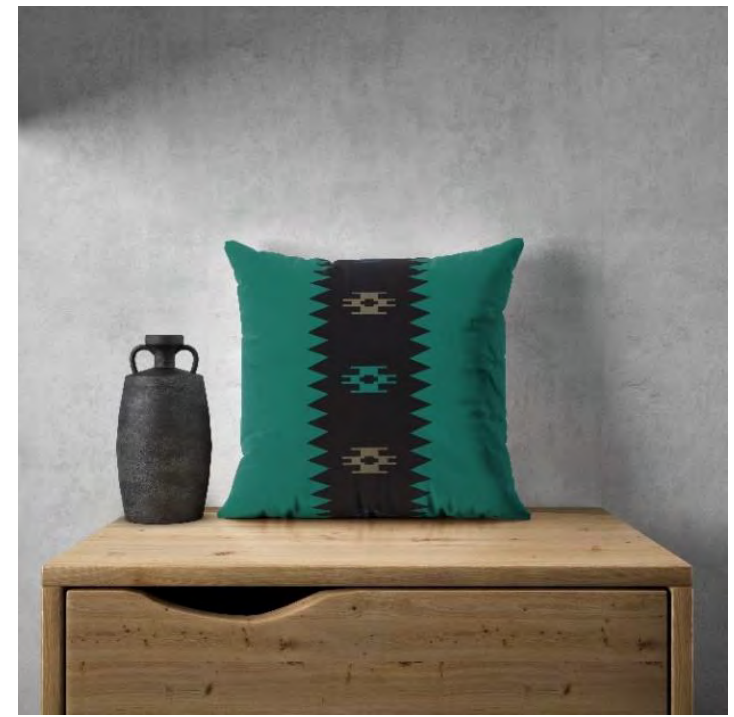

Сл. 159 Текстилни производи - варијанта 3

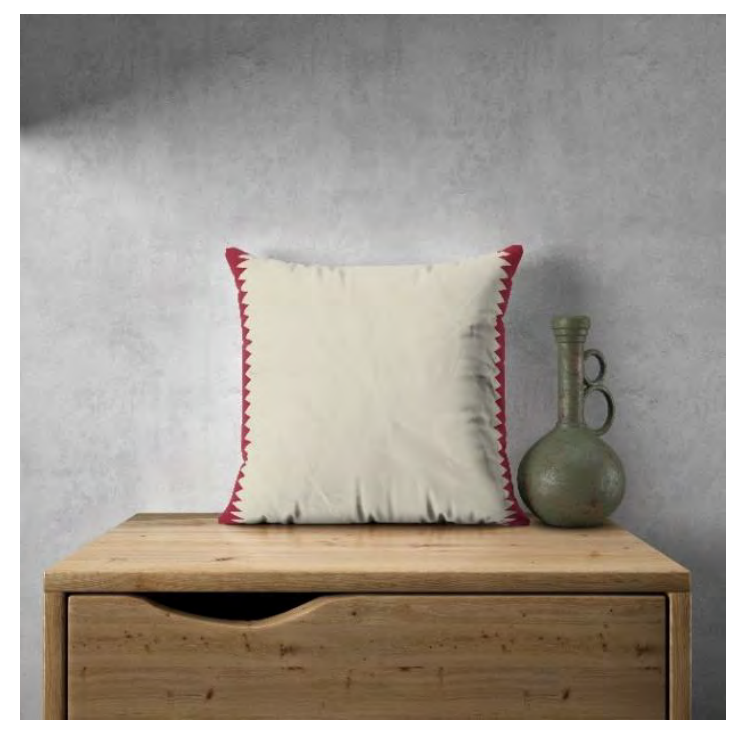

Сл. 161 Текстилни производи - варијанта 5

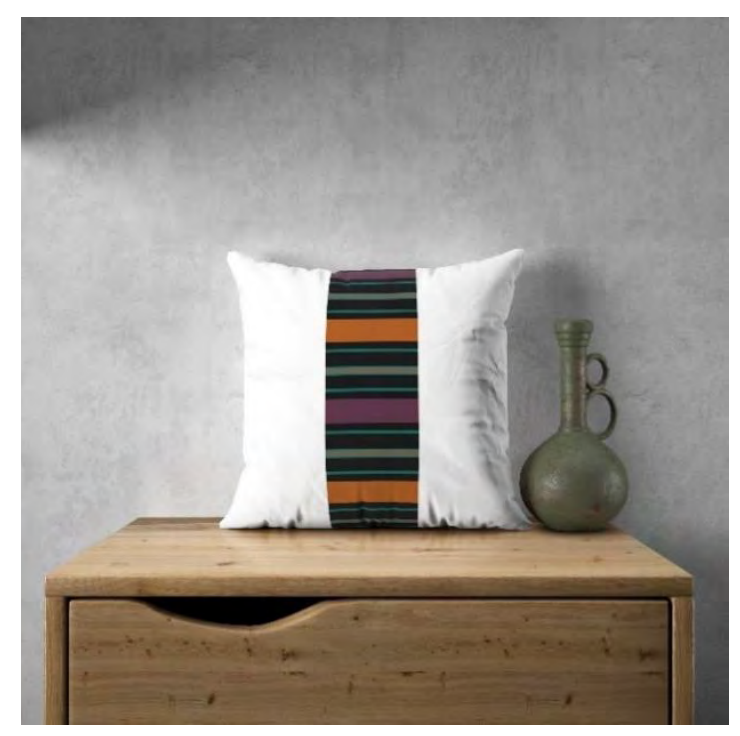

Сл. 163 Текстилни производи - варијанта 7

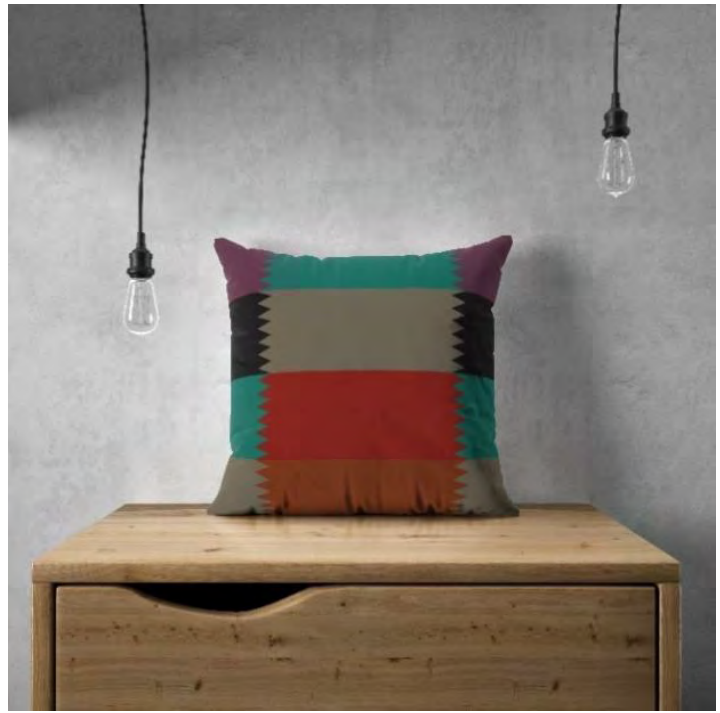

Сл. 160 Текстилни производи - варијанта 4

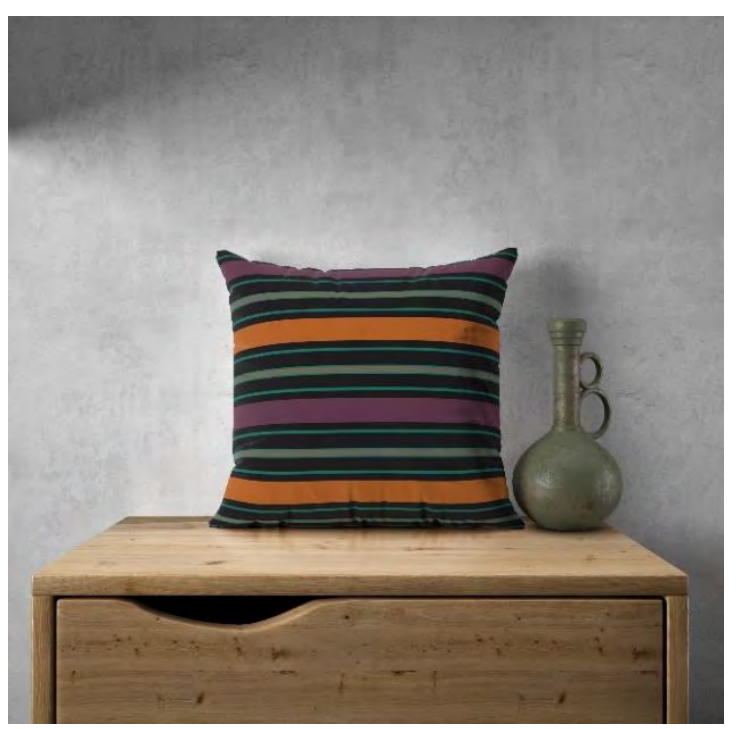

Сл. 162 Текстилни производи - варијанта 6

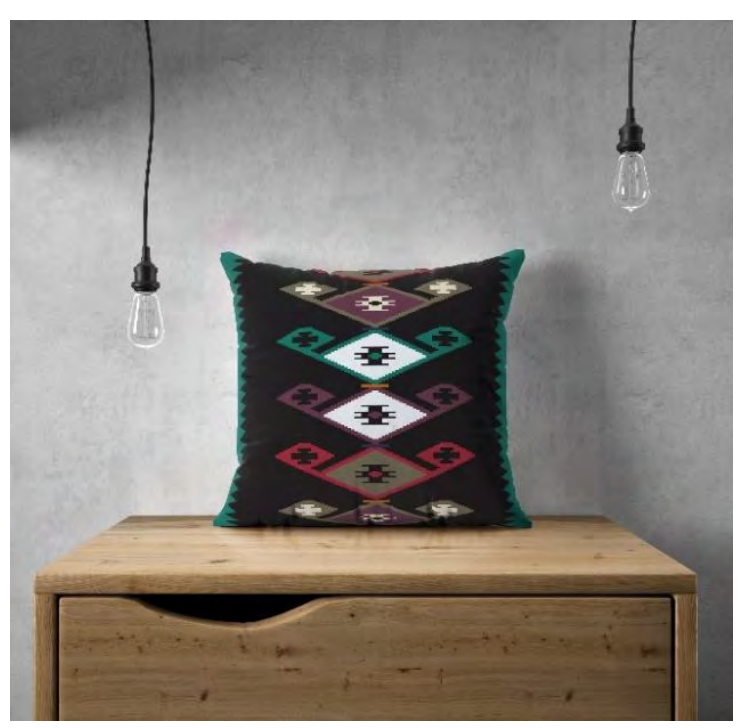

Сл. 164 Текстилни производи - варијанта 8 
Пример 4 - параван изработен од дрво со реинтерпретирана текстилна шара
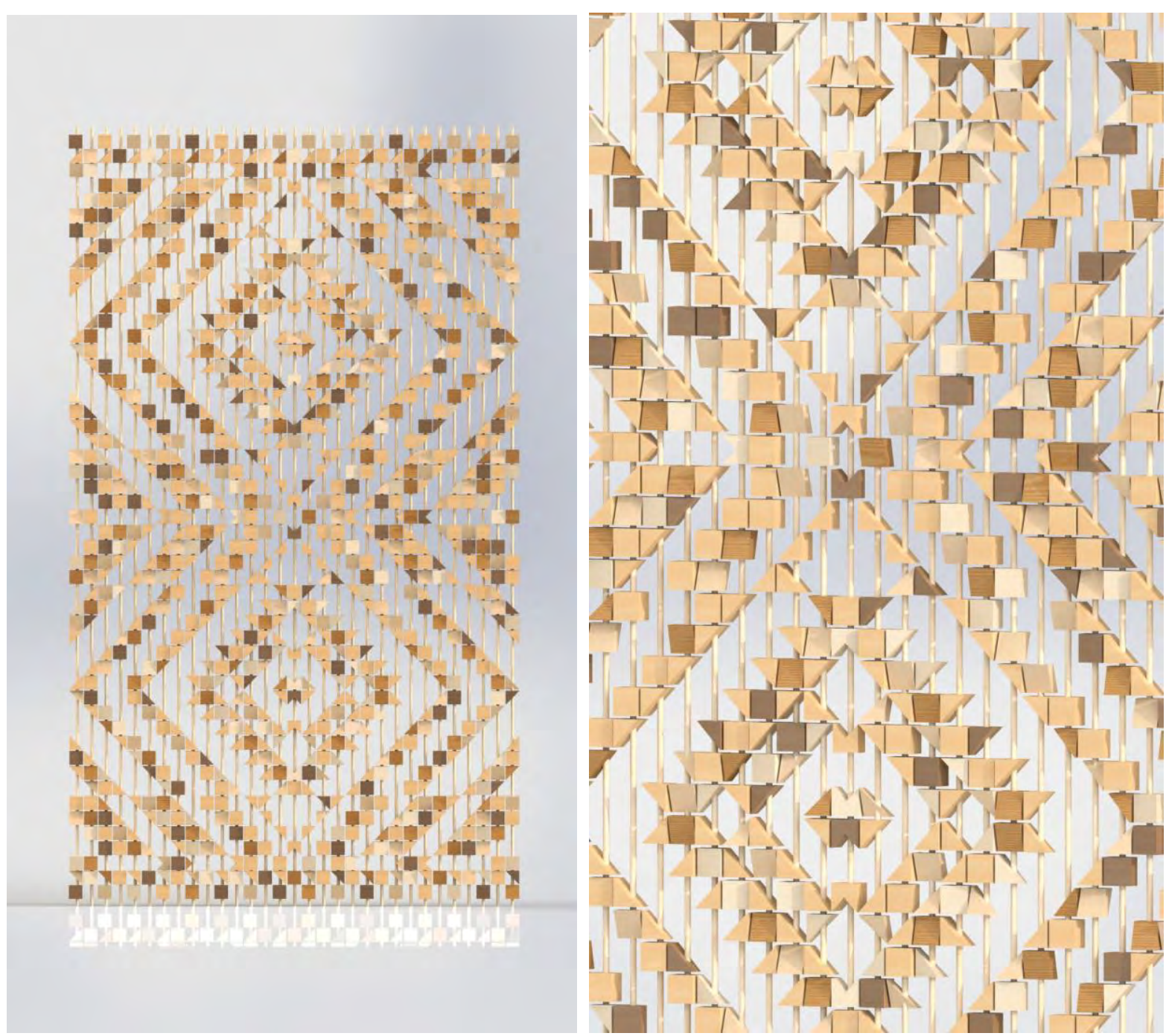

Сл. 165. и 166. Дрвен параван 


\section{8. Заклучок}

Во оваа магистерска работа е спроведено истражување чиј главен фокус е да се понуди методологија за извлекување типични визуелни карактеристики, дизајнерски елементи и принципи, автентични за македонските традиционални предмети, како и алатка за нивно имплементирање во модерниот индустриски дизајн. Крајна цел е да се обезбеди препознатливост на визуелните карактеристики на културниот идентитет и традиционалните вредности на нашиот народ.

Поради огромното богатство на предмети од македонската традиција направен е потесен избор на по неколку примероци од пет категории предмети, врз кои е извршена анализата на визуелните карактеристики. Крајниот исход од оваа фаза е база од карактеристичните елементи (форми, бои, нијанси, текстури и материјали) и карактеристичните принципи во вид на визуелни правила (композиција, ритмика, рамнотежа, симплификација, пропорција, единството во делата, итн.), презентирана во вид на серија од морфолошки матрици кои нудат можност за меѓусебно комбинирање. Сите тие се градбени единки на естетиката со која се создава визуелна препознатливост на македонската традиција. Оваа база има можност да биде применета како алатка за извлекување инспирација за конкретни производи, чии визуелни карактеристики се одликуваат со препознатливост на македонската култура и традиција, поточно во креирањето обележја на културниот идентитет во дизајнот на производи.

Ова истражување имаше цел да понуди корисна постапка со која може да се проучуваат безбројните примери на функционални и декоративни предмети од секојдневниот живот на нашите предци. Ваквите истражувања можат да ја збогатат базата градбени елементи на естетиката на македонските производи од минатото со цел да бидат применети во креирање производи од сите области на дизајнот и архитектурата. Истражувањето може понатаму да се надгради како софтверска алатка или веб платформа за дополнување и сортирање на новите препознаени елементи и принципи на естетиката, како и можности за нивни алтерации, со што можностите за нови креативни концепти стануваат уште поголеми. 


\section{Референци}

[1] Brook, Isis, 2000 "Can 'Spirit of Place' be a guide to Ethical Building" in W. Fox (ed) 2000 Ethics and the Built Environment, (London: Routledge), 139-151

[2] Maslow, A.H. (1943). "A theory of human motivation". Psychological Review. 50 (4): 370-96. CiteSeerX 10.1.1.334.7586. doi:10.1037/h0054346. hdl:10983/23610]

[3] Hekkert. P., Design aesthetics: principles of pleasure in design, Psychology Science, Volume 48, $2006(2)$, p. $157-172$

[4] Knoop W.G., Breemen E.J.J. van, Horváth I., Vergeest, J.S.M. and Pham B., "Towards Computer Supported Design for Aesthetics", 31st ASATA - International Symposium on Automotive Technology and Automation, Dusseldorf, Germany, 2-5 June 1998

[5] Pham, B (1999) Design for aesthetics: interactions of design variables and aesthetic properties. In Proceeding of SPIE IS\&T/SPIE 11th Annual Symposium - Electronic Imaging '99, Vol 3644 pages, pp. 364- 371, San Jose, USA.

[6] Behrens.R Art, "Design and gestalt theory". Vol. 31, No. 4 (1998), pp. 299-303, Published by: The MIT Press. 1998.

[7] A. Ali, A. Liem, "The use of formal aesthetic principles as a tool for design conceptualisation and detailing", NordDesign 2014, Espoo, Finland / Melbourne, Australia

[8] Tschumi, B. "The Manhattan Transcripts" Academy Editions, 1981, University of Virginia

[9] Paul Uhlmann (2020) Architects builds barn-like rural retreat in Australian bush. Dezeen. https://www.dezeen.com/2020/03/10/paul-uhlmann-architects-barn-holiday-home-australia/

[10] Sinclair, B.R. Japanese Spirituality, Flexibility and Design: Influences and Impacts on Agile Architecture + Open Building University of Calgary + sinclairstudio inc., Calgary, Canada

[11] McCarty, C., McQuaid, M. (1998). Structure And Surface: Contemporary Japanese Textiles, The Museum of Modern Art, New York 2002; 12-78

[12] Cybulska, M., Dróżdż, T., (2016). Traditional Japanese Shibori and Contemporary Textile Design, TEXTILES OF THE SILK ROAD, Design and decorative techniques: from Far East to Europe, The Traditions of Non-European Cultures Vol. 4. Polish Institute of World Art Studies, Tako Publishing House, Warsaw, Torun

[13] Searle, K. (2008) Knitting Art: 150 Innovative Works from 18 Contemporary Artists, Voyageur Press, Minneapolis 2008:26-31

[14] Ólöf Gerður Sigfúsdóttir, "Nature, Nostalgia, and Narrative: Material Identity in Icelandic Design", in Iceland and Images of the North, eds. Sumarliði R. Ísleifsson with the collaboration of Daniel Chartier, Québec: Presses de I'Université du Québec, "Droit au Pôle" series, and Reykjavík: ReykjavíkurAkademían, 2011.

[15] Stewart, S. (1993). On Longing. Narratives of the Miniature, the Gigantic, the Souvenir, the Collection, Durham: Duke University Press. 
[16] Gunnalaugsdóttir, G. L. (2007). [No title], in Magma/Kvika-Íslensk samtímahönnun [Magma/Kvika-Modern Icelandic Design], eds. P. E. Elínardóttir, H. Yngvason, \& G. Gissurardóttir, Reykjavík: Listasafn Reykjavíkur, pp. 6-7.]

[17] Ólafsdóttir, Á. (2005). "There's God in the Barbed Wire, Granny (Megas)," in Ómur. Landið og pjóđin í íslenskri hönnun [Resonance.The Country and Nation in Icelandic Design], eds. G. Guðmundsdóttir \& S. Sigurđardóttir, Reykjavík: Pjóđminjasafn Íslands.

[18] Ab. Aziz, S. \& Olalere, F. E. (2013). Integrating the Malay traditional design elements into contemporary design: An approach towards sustainable innovation. ICIMTR2013. Procedia - Social and Behavioral Sciences. (c) 2013 Published by Elsevier Ltd.

[19] Crossly, L. (2003). Building emotions in design, PDD group. The Design Journal, 6(3), 35-45. doi: $10.2752 / 146069203789355264$

[20] Charter, M., \& Clark, T. (2007). Sustainable solutions. The Centre for Sustainable Design

[21] Haziyah, H., Zawiyah, B., Aminuddin, H., Aishah@Eshah, H. M. (2012). The philosophy in the creation of traditional Malay carving motifs in Peninsula Malaysia. Malaysia Journal of Society and Space, 8(7), pg 88-95, ISSN 2180-2491

[22] Wan, H. \& Abdul, H. N. (2011). The traditional Malay house. ITNM Berhad

[23] Цветковски, Л. Digital Prints Arcade Tradition (2017)

https://ladislavcvetkovski.blogspot.com/2017/09/digital-prints-arcade-tradition.html

[24] Томиќ, Р. Д. https://komradrug.com.mk/

[25] https://fashionel.mk/moda/kolekcii/fwsk-kulturnoto-nasledstvo-kako-modna-inspiracija-zastudentite-od-evropski

[26] Кличкова Вера, Македонски народни носии, Скопје 1963, стр. 3. 